
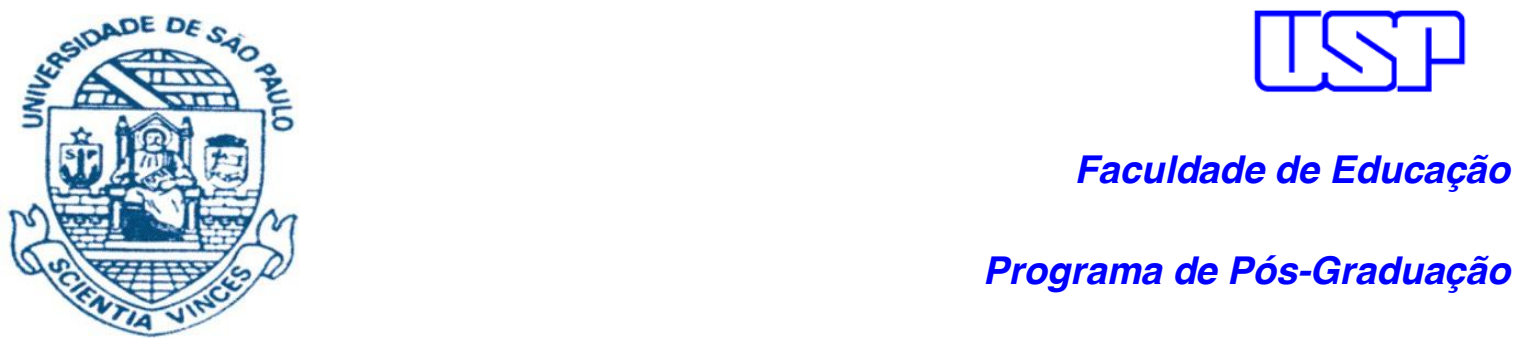

Programa de Pós-Graduação

ALEXANDRE DE PAULA FRANCO

A FORMAÇÃO DOS GESTORES ESCOLARES NOS CURSOS DE PEDAGOGLA

SÃO PAULO

2014 


\section{A FORMAÇÃO DOS GESTORES ESCOLARES NOS CURSOS DE PEDAGOGIA}

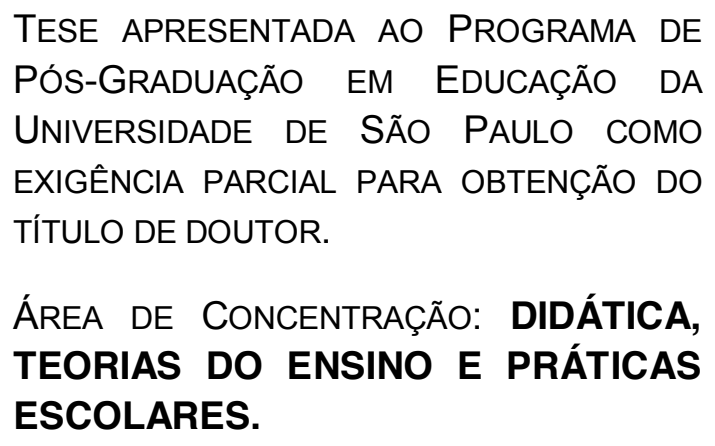

ORIENTAÇÃo: PRofa. DRA. MARIA ISABEL DE ALMEIDA

\section{SÃO PAULO}




\section{A FORMAÇÃO DOS GESTORES ESCOLARES NO CURSO DE PEDAGOGLA}

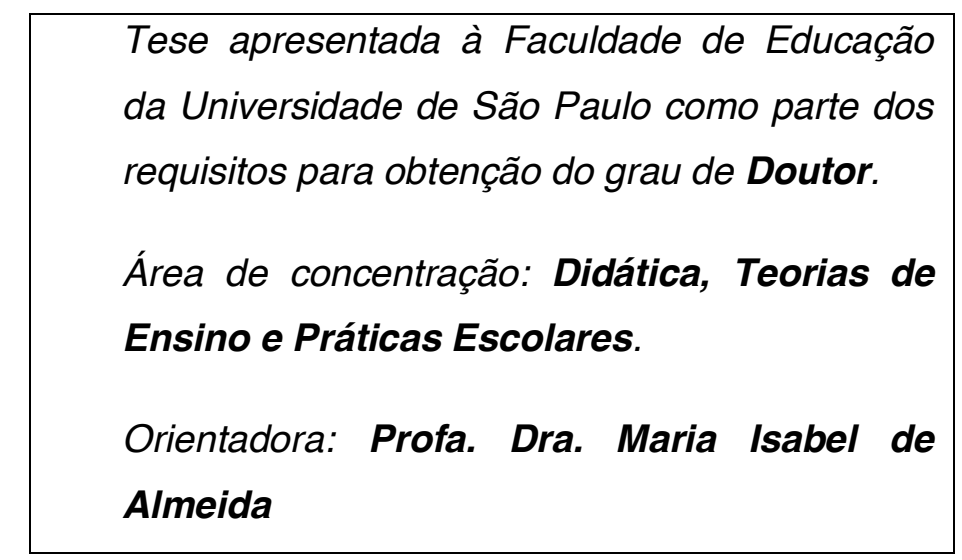

Aprovado em

BANCA EXAMINADORA

Profa. Dra. Maria Isabel de Almeida

FEUSP

Assinatura

Prof. Dr. José Cerchi Fusari

FEUSP

Assinatura

Profa. Dra. Mitsuko Aparecida Makino Antunes

PUCSP

Assinatura

Prof. Dr. Umberto de Andrade Pinto UNIFESP

Assinatura

Prof. Dr. Yoshie Ussami Ferrari Leite

UNESP

Assinatura 
Autorizo a reprodução e divulgação total ou parcial deste trabalho, por qualquer meio convencional ou eletrônico, para fins de estudo e pesquisa, desde que citada a fonte.

Catalogação na Publicação

Serviço de Biblioteca e Documentação

Faculdade de Educação da Universidade de São Paulo

378.3037 Franco, Alexandre de Paula

B277d A formação dos gestores escolares nos cursos de pedagogia / Alexandre de Paula Franco ; orientação Maria Isabel de Almeida. São Paulo : s.n., 2014.

300 p. : il., grafs. tabs.

Tese (Doutorado - Programa de Pós-Graduação em Educação. Área de Concentração : Didática, Teorias do Ensino e Práticas Escolares ) -- Faculdade de Educação da Universidade de São Paulo)

1. Pedagogia - Curso 2. Pedagogos 3. Formação de professores 4. Instituições de ensino - Desenvolvimento. I. Almeida, Maria Isabel de, orient. 
À minha amada Mãe e meu amado Pai, pelo eterno e incondicional amor e companhia. 


\section{Agradecimentos}

O tempo passou e nem parece que caminhei tanto para chegar aqui, depois de uma longa jornada na vida, na USP, no trabalho, e com tantos momentos e pessoas que se fizeram tão especiais na construção desta parte da história da minha vida, o que me leva a profundos e sinceros agradecimentos.

Deixo aqui meu agradecimento a minha orientadora Profa. Dra. Maria Isabel de Almeida, que esteve presente durante 8 anos da minha vida acadêmica, tanto na caminhada do mestrado, como no doutorado. Lembro-me, como se fosse hoje, do primeiro acolhimento, de todas as nossas conversas, da força nos momentos de desalento e do respeito nas horas mais turbulentas. Sua confiança e créditos me apoiaram intensamente para que eu chegasse até aqui.

Ao Prof. Dr..José Cerchi Fusari, agradeço por também ter me acolhido e possibilitado aprender com ele, pessoa mais que humana, professor mais que professor, gente mais que gente. Agradeço, profundamente, por ter, durante todo o tempo, valorizado, sobretudo, minha condição de professor da rede pública.

À Secretaria de Estado da Educação de São Paulo pelo financiamento desta pesquisa, através do Programa Bolsa Doutorado, demonstrando uma forma de valorização profissional e que há tantos anos dedica seu trabalho à melhoria da escola pública, inclusive na tentativa de que esta tese possa colaborar para a melhoria do trabalho da rede e da educação.

Aos meus professores, tantos e tantos, que me fizeram professor e desvelaram meu desejo em acreditar nesta carreira, em investir neste modo de vida, em conhecer os desafios e as virtudes da escola e do ser docente. Principalmente aqueles que me acompanharam na vida escolar e também os que fizeram parte dos meus primeiros anos de trabalho. 
Aos sempre amigos da Supervisão de Ensino, Diretores de Escola e Professores Coordenadores, que há mais de 10 anos me acompanham, respeitam e dedicam a mim sua paciência e generosidade, fortalecendo-me durante todos estes anos, para que a jornada não seja em vão, nem solitária, e para os quais devo tanto votos de saudações. Do mesmo modo aos amigos da UNISAL, professores que estiveram presentes, de modo fraterno, em momentos tão especiais da minha vida pessoal e profissional.

Ao Emerson, que, sempre por perto, animou-me e deu força, para que eu continuasse firme na jornada e chegasse até o final da etapa $e$ primorosamente dedicou-se a revisão de todo este trabalho, além das longas trocas de idéias. Assim como ao Flávio e Valéria, que em muitos momentos ajudaram-me na organização no trabalho, na esperança e pela histórica amizade. Assim como à Vivian, por tanta paciência ao final deste trabalho.

À minha família pelo afago, respeito, apoio e valor que tanto tem me dado durante todos estes anos de vida, em especial aos meus irmãos Douglas e Anderson, irmã Naiara e minha tia Vera. E aqueles que já não estão aqui tão próximos, mas que hoje festejam esta conquista, fazendo-se presentes, como minha saudosa avó.

Ao meu pai e minha mãe, meus grandes e eternos amores, Pedro e Cecília, sem os quais nada disso aconteceria, e pelos quais, mesmo que nada de tão especial na minha vida ocorresse, ela já valeria, apenas pelo fato de ter sido gerado, nascido e criado em tão profundo e incondicional amor. A eles dedico todo este trabalho, conquista e reconhecimento profissional, sendo tudo isto singelo diante de tudo que eles me dão.

Finalmente, mas não por último, a Deus, por ter removido as maiores pedras do meu caminho, ter me dado força para transpor as barreiras, ter fortalecido minha fé nos momentos mais difíceis e ter me colocado diante de tantas pessoas especiais e conquistas na vida pessoal, acadêmica e profissional. 
"Nenhum vento ajuda a quem não sabe para que porto velejar" Montaigne 


\section{Resumo}

A presente tese tem por objetivo a investigação da formação em ensino superior dos gestores escolares, denominados de especialistas de educação, até a edição da atual Lei de Diretrizes e Bases da Educação Nacional. Definiuse como corpus desta pesquisa, matrizes curriculares dos cursos de Pedagogia e a convergência destas com as necessidades encontradas pelos profissionais no exercício da coordenação pedagógica, da direção de escola, da supervisão ou da orientação educacional, considerando a possibilidade de trabalho na perspectiva do desenvolvimento institucional e profissional. Esta pesquisa está circunstanciada no âmbito das abordagens qualitativas, tomando como referência metodológica a triangulação de dados analisados pelo viés da multirreferencialidade (ARDOINO, 1998; BARBOSA, 1998), uma vez que foram abordados os dispositivos legais que originaram e, mais recentemente, orientam o curso de Pedagogia, implicando no conceito sobre o que é gestão. Num primeiro momento, contemplo-se o histórico do curso de Pedagogia, desde a sua gênese no Brasil, e a incorporação da profissionalização dos especialistas de educação num processo de ambigüidades e busca de identidade tanto do curso quanto dos pedagogos (BRZEZINSKI, 2002; FREITAS, 2002; PIMENTA, 2002). Em seguida, discutiram-se as diferentes interpretações atribuídas ao termo gestão, considerando os variados contextos nos quais tem sido empregada esta nomenclatura, ora para especialistas, ora para gestores escolares (EVANGELISTA, 2003; LIBÂNEO, 2001, SCHEIBE, 2003, PARO, 2011). Logo após, apresenta-se a análise das tendências propostas na formação dos cursos de Pedagogia no Brasil, analisando criticamente que "lugar" tem sido atribuído à profissionalização dos gestores escolares, num curso que passou a ter como atribuição o tratamento de todos os campos de atuação do pedagogo, considerando a perspectiva do desenvolvimento institucional (ALMEIDA, 1999; DAY, 2001, FULLAN, 2009). Os resultados desta pesquisa indicaram a relevância de se propor outra abordagem para a formação dos gestores nos cursos de Pedagogia, o que implica em alterações na estrutura destes, sobretudo, no que se refere ao currículo, integração do curso e redefinição de uma licenciatura que contempla ao mesmo tempo aspectos de bacharelado, numa tentativa de superar as ambigüidades ainda presentes no curso e na construção da identidade dos gestores escolares, e aponta para um outro caráter de percurso formativo no ensino superior.

Palavras-chave: Curso de Pedagogia. Gestão Escolar. Especialistas em Educação. Formação Inicial. Desenvolvimento Institucional. 


\begin{abstract}
This thesis aims to research the professionalization of university school managers, called education specialists until the current edition of the "Lei de Diretrizes e Bases da Educação Nacional, n. 9394 of 1996". We have defined as corpus of this research, curricular matrices of Pedagogy courses and the convergence of these with the needs found by professionals in pedagogical coordination, the direction of school, the supervision or the educational orientation, considering the possibility of working from the perspective of institutional and professional development. This research is detailed in the framework of qualitative approaches, with reference to methodological triangulation of data analyzed through the bias of multiple references (ARDOINO, 1998; BARBOSA, 1998), since we will bring the legal devices that originated and guide the course Pedagogy, resulting in the concept of what is management. First of all, we will deal with the history of the Pedagogy course, since its genesis in Brazil and the incorporation of the professionalization of the specialists of education in a process of ambiguities and search for identity both of the course as educationalists (BRZEZINSKI, 2002; FREITAS, 2002; PIMENTA, 2002). Then we will discuss the different interpretation given to the term management, considering the many contexts in which it has been used this nomenclature, sometimes to specialists, sometimes with school managers (EVANGELISTA, 2003; LIBÂNEO, 2001, SCHEIBE, 2003, PARO, 2011). After that, it will be dedicated to analysis of trends proposed in the formation of Pedagogy courses in Brazil, critically reviewing that "place" has been assigned to the professionalization of school managers, in a course which became as treatment of all fields of professionalism of the pedagogue, considering the perspective of institutional development (ALMEIDA, 1999; DAY, 2001, FULLAN, 2009). The results of this research indicated the importance of proposing another approach to the training of managers in Pedagogy courses, which implies changes in the structure of these, especially in relation to curriculum, integration of the course and redefinition of a graduation that includes both aspects of bachelor in an attempt to overcome the ambiguities still present in the course, and the identity construction of school managers.
\end{abstract}

Keywords: Pedagogy Course. School Management. Specialists in Education. Professionalization Principal. Institutional Development. 


\section{LISTA DE ILUSTRAÇÕES}

Esquema 1 Campos de Atuação dos Gestores.

192

Esquema 2 Tendências identificadas nas relações de poder entre a escola $(E)$ e a Supervisão (S) 213

Esquema 3 Multirreferencialidade de elementos a serem analisados na pesquisa 223

Esquema 4 Disciplinas diversas nos cursos de Pedagogia 230

Esquema 5 As diversas nomenclaturas sobre Gestão 233

Esquema 6 Disciplinas Clássicas no Campo da formação dos especialistas de Educação. 237

Esquema 7 Aspectos para o Desenvolvimento Institucional. 266

Esquema 8 A espiral do desenvolvimento escolar. 267

Esquema 9 Contexto Atual 277

Esquema 10 Contexto Proposto. 278 


\section{LISTA DE GRÁFICOS}

Gráfico 1 Corpus da pesquisa ..................................................... 104

Gráfico 2 Natureza das Instituições................................................104

Gráfico 3 Distribuição Geográfica das Matrizes Oferecidas..................107

Gráfico 4 Localização por Centros..................................................... 108

Gráfico 5 Situações de Matrículas Optativas no interior dos Semestres ou

Anos. 109

Gráfico 6 Possibilidade de Diversificação Curricular.............................110

Gráfico 7 Duração de Cursos Oferecidos............................................113

Gráfico 8 Duração dos Cursos / Tipos de Instituições.......................... 113

Gráfico 9 Cargas Horárias Oferecidas.............................................. 114

Gráfico 10 Carga Horária Presencial Semanal - Privada / Pública........ 115

Gráfico 11 Carga Horária de Atividades Complementares nos Cursos de

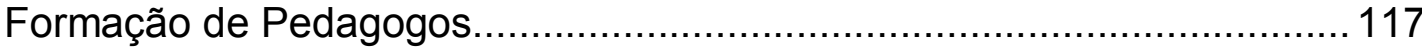

Gráfico 12 Carga Horária de Atividades Complementares / Tipo de

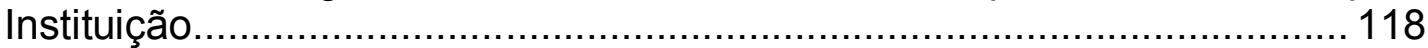

Gráfico 13 Foco de Atuação durante os Estágios Supervisionados....... 119

Gráfico 14 Atribuições/habilidades estabelecidas pela Resolução SE 88/07 242

Gráfico 15 Atribuições/habilidades estabelecidas pela Resolução SE $70 / 10$ 


\section{LISTA DE TABELAS}

Tabela 1 Distribuição das pesquisas sobre Gestão Escolar nos 07 anos

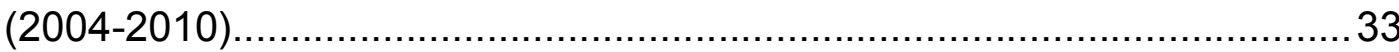

Tabela 2 Distribuição das pesquisas por foco sobre a Gestão Escolar

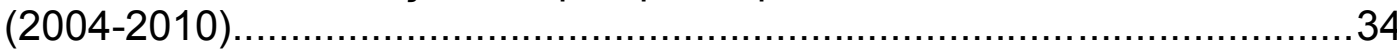

Tabela 3 Alterações legais nos dispositivos geradores das Diretrizes Curriculares Nacionais para a Pedagogia (1).

Tabela 4 Alterações legais nos dispositivos geradores das Diretrizes Curriculares Nacionais para a Pedagogia (2)........................................ 92

Tabela 5 Alterações legais nos dispositivos geradores das Diretrizes Curriculares Nacionais para a Pedagogia (3).

Tabela 6 Amostragem dos cargos e funções de suporte pedagógico nos sistemas de ensino. 155

Tabela $7 \quad$ Análise comparativa: Competências dos egressos do curso de Pedagogia e competências dos gestores da Rede Estadual de São Paulo.172

Tabela 8 Habilidades Específicas para cargos de Diretor e Supervisor.179

Tabela 9 Capacidades Exigidas nas Dimensões do Trabalho do Gestor.196

Tabela 10 Análise dos eixos de atuação $x$ competências mobilizadas pelos gestores 201

Tabela 11 Conteúdos relevantes do Curso de Pedagogia para o trabalho de suporte pedagógico, segundo os gestores escolares 209

Tabela 12 Disciplinas encontradas em vários cursos de Pedagogia analisados.

Tabela 13 Principais Conteúdos de Trabalho (segundo os gestores).... 246

Tabela 14 Principais conhecimentos trazidos da formação inicial em Pedagogia (segundo os gestores).

Tabela 15 Tratamento dos conteúdos na formação inicial, segundo os sujeitos 252

Tabela 16 Categorias e Conteúdos do Trabalho dos Gestores Escolares (segundo seus depoimentos) 


\section{SUMÁRIO}

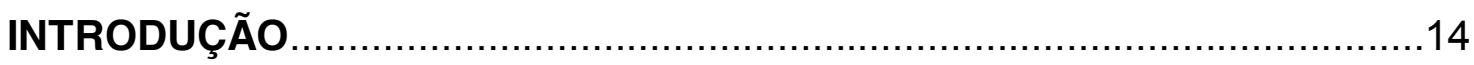

Da justificativa e objetivos da pesquisa................................................... 15

Da definição do corpus da pesquisa................................................... 32

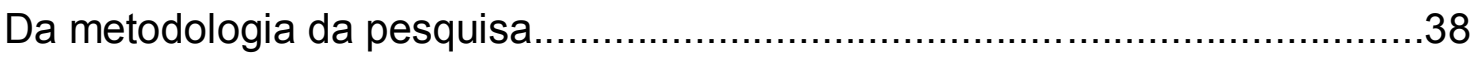

Dos procedimentos metodológicos ...................................................46

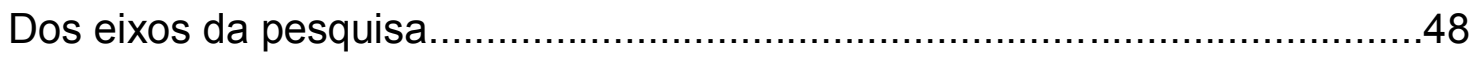

CAPÍTULO I - Percurso histórico e legal da formação dos gestores

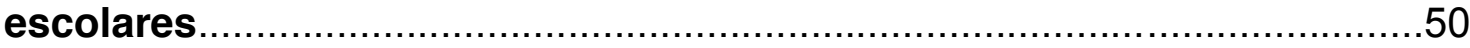

1.1 A configuração da formação dos gestores escolares nos últimos anos referências legais.................................................................... 51

1.2 O curso de Pedagogia pós lei 9394/96: impasses e avanços na formação dos especialistas de educação.

1.3 O sentido e o significado da Pedagogia - alguns dados sobre esta licenciatura pós Diretrizes Curriculares Nacionais .96

1.4 Aspectos preliminares para análise dos cursos de Pedagogia na pesquisa. 103

CAPÍTULO II - Conceitos e fundamentos sobre a gestão escolar e sobre a profissionalidade dos gestores

2.1 A gestão do trabalho na escola: do conceito e das expectativas profissionais. 
2.2 Dos dilemas conceituais sobre "especialistas" em educação e "gestores escolares": legalidade e profissionalidade. 147

2.3 O que dizem os profissionais do magistério atuantes na gestão escolar sobre os desafios de sua atuação. 188

CAPÍTULO III - Da formação inicial e profissionalidade dos gestores escolares: possibilidades de desenvolvimento institucional. 220

3.1 A proposta de formação para os gestores escolares: o que trazem os cursos de Pedagogia 223

3.2 O que fazem os gestores escolares: encontros e desencontros com sua formação inicial. 240

3.3 Quando a gestão escolar contribui para o desenvolvimento institucional 258

4.1 Encontros e desencontros entre a formação e as necessidades anunciadas .271

4.2 Dos obstáculos encontrados e das alternativas apontadas. .275

CONCLUSÃO .282

REFERÊNCIAS 289 


\section{Introdução}

Desde o final da década de 1930, quando o curso de Pedagogia no Brasil foi criado, de forma mais sistematizada e institucional, perdura o dilema sobre a identidade de como tal formação seria estruturada e de qual seria sua finalidade aos egressos, sobretudo em se tratando a quem seria destinado e, porquanto, quais capacidades seriam priorizadas, considerando-se, naquele momento, a atuação dos profissionais se daria na escola ou nas instâncias centrais de controle desta instituição.

Partindo deste contexto, a presente pesquisa se destina a restaurar o movimento histórico do curso de Pedagogia, que passa inicialmente pela "formação dos técnicos" em educação, posteriormente pelos "chamados especialistas" em educação e, mais recentemente, "gestores em educação".

As referências que foram estabelecidas para a formação dos profissionais do magistério que atuam nas atividades de administração, planejamento, coordenação, supervisão e orientação, estão em conformidade com o artigo 64 da Lei 9394 de 1996.

Como campo de pesquisa, elegemos a investigação do que se compreende como "gestão em educação e na escola", a partir de referências já existentes e de uma concepção adotada para a análise dos dados que será destacada durante o trabalho. Todavia, já antecipamos que, neste caso, julgamos a gestão como atividade convergente à docência no plano da escola, ou seja, não se opõe a ela, estando vinculada ao objetivo da aprendizagem dos diferentes sujeitos que atuam prioritariamente na escola pública.

Deste modo, há a intenção de analisar se a maneira que se propõe para a formação dos gestores escolares nos cursos de Pedagogia, pós Diretrizes Curriculares Nacionais do Curso (2006), corrobora a perspectiva propositiva de atuação na escola, sendo então fundamental destacar como aspectos constituintes deste trabalho: o movimento de formação dos gestores 
(profissionalização), as demandas e necessidades, e assim como seu modo de agir (profissionalidade), e contexto constituído no campo de seu trabalho e o impacto sobre sua prática (práxis), que implica finalmente no profissionalismo com o qual desenvolvem seus ofícios de gestão.

Para a construção desta pesquisa de abordagem qualitativa, utilizaremos a metodologia de triangulação de dados, interligando os indícios e dados trazidos pela legislação, histórico e diretrizes do curso de Pedagogia. Trabalharemos também com depoimentos dos profissionais que realizam a gestão escolar na escola, apresentando a relação construída entre sua formação e sua atuação; e a organização atual dos cursos de Pedagogia no Brasil, com vistas à análise das possibilidades de formação propostas, apoiados na abordagem multirreferencial.

Finalmente, o intuito é de comprovamos em que medida a formação no ensino superior para os gestores escolares, nos atuais cursos de Pedagogia, conferem condições e elementos curriculares que possam contribuir para a formação destes profissionais na perspectiva do desenvolvimento profissional destes sujeitos, subsidiando-os para atuarem na melhoria institucional, na profissionalização de outros sujeitos e na qualidade dos resultados alcançados pela escola pública, em razão do avanço de seu projeto educativo.

\section{Da justificativa e objetivos da pesquisa}

Como argumento para justificar esta pesquisa e articular os aspectos que irão nortear este trabalho, optamos por nos valer de categorias que possam indicar nossa inserção como sujeito social e que ratifiquem que esta investigação se constrói a partir do reconhecimento de que os sujeitos são plurais, e portanto se constituem por diferentes aspectos, dentre eles destacamos: pessoais, culturais, políticos, ideológicos, profissionais, acadêmicos e científicos, aspectos estes que se colocam como elementos intervenientes neste tipo de pesquisa. 
Inicialmente, justificamos que a trajetória profissional que temos percorrido nos últimos anos tem sido motivadora no processo de questionamento sobre quais as provocações que se mostram como mais marcantes, tendo atuado nos diferentes ofícios do pedagogo, como professor de ensino fundamental nas séries iniciais, finais e no ensino médio, assistente pedagógico, diretor de escola e, finalmente, nos últimos anos como supervisor de ensino, o que implicou vivenciar diferentes campos da profissionalidade pedagógica, mais especificamente na escola pública estadual.

Tal trajetória trouxe uma intensa aproximação cultural e pessoal com o mundo escolar, com o campo educacional e com os elementos que se configuram como aspectos de convergência e divergência entre a minha própria percepção de mundo enquanto pessoa e os contextos escolares.

A profissionalização a que fizemos menção, na introdução da presente tese, aproximou-me de diversos contextos de trabalho, nos quais as exigências de competências e de saberes pedagógicos demonstram que o pedagogo não pode prescindir de formação. Ele precisa de uma base consistente para lidar com os desafios de trabalho em diferentes situações pedagógicas de gestão do sistema educacional e da organização da escola, o que evidenciou que a cultura do mundo educativo precisa ser desafiada pelas habilidades e competências mais diretamente ligadas à categoria profissional.

Concomitantemente ao trabalho como pedagogo nas atividades de gestão da educação básica, atuamos como docente e, nos últimos anos, especificamente no meu caso, como coordenador do curso de Pedagogia, o que nos possibilitou observar a relação entre o processo de formação acadêmica de pedagogos, sua formação inicial, e os dilemas anunciados em suas primeiras aproximações com o mundo educativo, o que nos levou a considerar a relevância das experiências acadêmicas na identidade profissional dos sujeitos.

A atuação profissional na qual me envolvi deriva de minha formação acadêmica que se originou na formação específica para o magistério, ainda no início da década de 1990, aprofundado pela licenciatura em Pedagogia e em 
Geografia, o que nos colocou diante da dedicação à causa do magistério e da docência.

Motivou-nos também outro fator mais diretamente ligado ao campo científico, com a realização do mestrado, junto ao Programa de Pós Graduação da Faculdade de Educação da Universidade de São Paulo, quando até 2007 desenvolvemos a pesquisa cujo tema foi $A$ profissionalidade dos supervisores de ensino da rede estadual paulista, possibilitando uma aproximação com o processo de investigação dos processos de atuação de uma categoria de gestores educacionais e sua profissionalização.

Ao ser definido o objeto desta pesquisa, delimitou-se investigar 0 contexto atual de formação dos gestores escolares, que historicamente são denominados "especialistas em educação" pela natureza de sua atividade não restritamente docente.

Neste sentido, esta pesquisa dedica-se a analisar a relação entre a formação universitária inicial de tais profissionais no âmbito do curso de Pedagogia, o que foi colocado como uma prerrogativa legal um tanto quanto contemporânea, a partir da LDB de 1996, e as interlocuções com as práticas emergentes no plano da profissionalidade desenvolvida nas escolas.

Neste caso, o entendimento que temos da Pedagogia como ciência apóia-se na investigação das relações educativas do ensino e da aprendizagem e corrobora a perspectiva de Morin (2002) ao defender que a educação não se configura como um processo de juntar conhecimentos fragmentado, o que ampliaria a ruptura entre o papel da ciência, neste caso educativa, e as questões que fazem parte do cotidiano pedagógico, o que atribui significado científico e valor pedagógico ao trabalho dos gestores escolares.

A concepção de educação e de Pedagogia que nos orienta, nesta pesquisa, é a de que esta ciência não se limita à investigação das questões do ensino, mas da complexidade do fenômeno educativo e, neste caso, inclusive de seus sujeitos, sua constituição profissional e a relação com a 
profissionalidade, idéia que coexiste com a compreensão de Libâneo (2001) ao defender a amplitude da ciência pedagógica:

\begin{abstract}
Sem descartar necessidade da análise epistemológica das ciências da educação ou dos critérios de demarcação do conceito de ciência, parto da idéia de que a Pedagogia é uma área de conhecimento que investiga a realidade educativa, no geral e no particular. Mediante conhecimentos específicos, filosóficos e técnico-profissionais, ela busca a explicitação de objetivos e formas de intervenção metodológica e organizativa em instância da atividade educativa implicadas no processo de transmissão/apropriação ativas dos saberes e dos modos de ação. Pedagogo é profissional que atua em várias instâncias da prática educativa, direta ou indiretamente ligadas à organização e aos processos de transmissão e assimilação ativa de saberes e de modos de ação, tendo em vista objetivos de formação humana definidos em sua própria contextualização histórica (LIBÂNEO, 2001, p.116).
\end{abstract}

A educação ${ }^{1}$, concebida através deste ponto de vista, é um processo permanente de mudança, que provoca a mobilização do capital cultural dos sujeitos e a confrontação com a ciência e com os desafios contemporâneos.

Educação, por assim dizer, é uma ação formativa e dialética, não sendo exclusivamente técnica ou metodológica. Partindo desse pressuposto, se espera orientar a formação do pedagogo e, no caso desta pesquisa, dos gestores escolares, também chamados de especialistas em educação.

Neste mesmo percurso teórico, complementamos com as considerações de Morin (2005) quando este nos alerta que deparamo-nos com um contexto de complexidade que nos leva a imersão numa relativa ilusão sobre o saber, seja ela na compreensão do objeto que elegemos ou no reconhecimento da

\footnotetext{
${ }^{1}$ Concebemos como educação o processo de construção integral do sujeito humano na sua relação com o outro, com o meio, com os fenômenos naturais e processos históricos, e inseridos nos contextos da vida, que vão se integrando a sua identidade pessoal, e pelos quais vão se tecendo as condições de humanização e socialização necessárias e características aos sujeitos humanos. Educação nesta perspectiva é uma forma do sujeito descobrir-se a si, e ao mesmo tempo, aos outros e ao mundo em que vive, considerando as potencialidades culturais, artísticas, científicas, cognitivas, afetivas, e relacionais. Parte do processo de educação da sociedade e do homem ocorre pela via da educação formal, que se firma em nossa sociedade pela escolarização, que não é responsável por toda a educação humana, e portanto, não tem em si todas as suas manifestações e possibilidades, ainda que deva ocorrer a partir das mais diversas experiências individuais e coletivas.
} 
sua pertinência com contradições ou ambigüidades do mundo contemporâneo e, por analogia, com o campo real da profissionalidade.

A pesquisa tratará de um esforço para agregar elementos legais, conceituais, documentais e depoimentos que permitam, qualitativamente, ajuizar "o lugar: tempo e espaço" atribuído à formação em nível superior dos gestores escolares nas atuais propostas dos cursos de Pedagogia, regidos pelas novas diretrizes curriculares e legais, detectando a compatibilidade entre o que se anuncia como perfil desejado pela lei.

O que se prevê como conteúdos de formação nos cursos de Pedagogia e em que medida tais prerrogativas convergem no sentido de contribuir para o desenvolvimento institucional das escolas, segundo as percepções de que os próprios sujeitos em questão constroem acerca de sua própria profissionalidade.

Os estudos que realizamos preliminarmente para a construção das proposições orientadoras desta pesquisa indicam que diversos estudos se dedicaram à investigação de problemas relacionados à vida dos professores, às culturas de trabalho, ao desenvolvimento institucional, ou mesmo, à importância da formação continuada para uma aludida qualidade em educação (NÓVOA, 1995; IMBERNÓN, 1994; CRÓ, 1998;; BREZINSKI, 2002; PARO, 2007; TARDIF, 2008).

Considerando-se que de modo geral estas apontam para a importância da educação como investimento social, que precisa se aproximar de uma lógica mais intelectual e menos burocrática de trabalho; o que implicaria em outras formas de sua realização, provavelmente mais criativa, autônoma, reflexiva e crítica.

Com efeito, ganha importância, nas pesquisas, o interesse em reconhecer o grau de melhoria qualitativa do trabalho na escola pública, a valorização profissional, o impacto da criação de programas, as formas de organização dos grupos de trabalho nas instituições e o projeto pedagógico de cada escola, como forma de admitir o compromisso político deste trabalho. 
Neste contexto, a cultura da escola ${ }^{2}$ e seu projeto acabam aligeirados e preteridos, em razão da concepção equivocada e reducionista da educação como despesa do Estado $^{3}$ e não uma garantia de direito social. Lógica esta que despreza a capacidade das instituições escolares construírem percursos próprios de trabalho e de formação, sem necessariamente o abandono de uma base comum da educação nacional, tanto para as aprendizagens, como para a formação dos profissionais, numa tentativa de superar a idéia de parâmetros generalistas ou padrões mínimos (ALMEIDA, 1999; TORRES, 2001; CANÁRIO, 2003; FREITAS, 2004).

O fato de reconhecermos que a melhoria da qualidade da educação não se restringe apenas à mudança do trabalho docente, move-nos também a destacar que os gestores escolares, responsáveis pelas formas, alternativas e possibilidades de organização do trabalho nas escolas, carecem de investigação mais depurada sobre como tem se dado sua formação nos últimos anos, e a relação da mesma com os desafios que lhe são apresentados na prática profissional. $O$ que de outro modo seria afirmar que se justifica a investigação das formas pelas quais se dá tal formação profissional.

Traremos evidências de que as pesquisas em educação ampliam-se tanto nas instituições públicas como nas privadas, principalmente para

\footnotetext{
${ }^{2}$ Nos apropriamos das contribuições de Luck (2009), para apontar o que conceituamos como cultura institucional, para a qual a autora denomina organizacional, ao definir: "O conceito de cultura organizacional se refere, pois, às práticas regulares e habituais da escola, à sua personalidade coletivamente construída e amalgamada, a partir do modo como as pessoas, em conjunto, pensam sobre a escola como um todo; sobre o papel que a escola representa em sua comunidade e na sociedade em geral; sobre o papel individual e coletivo das atuações de seus participantes. Também se refere aos valores que expressam e traduzem em seus discursos comuns, em suas ações cotidianas e em sua comunicação e relacionamento interpessoal regularmente estabelecidos".
}

3 Sobretudo a partir da década de 1990, sob a lógica da expansão do neoliberalismo econômico no mundo, que inclusive passa a assolar ainda mais os investimentos em educação, sob o discurso da importância da racionalização, surge uma expressão muito comum entre os economistas que se tornam os mentores das políticas públicas, inclusive nos países da América Latina: educação como investimento do Estado. Embora tal perspectiva aparentemente soe como reconhecimento com visão mais social, esta é uma idéia que reforça a presunção de que garantir a educação e a escolaridade à população é uma das maneiras mais eficazes de se atender às demandas do Estado, de modo que possam ser devolvidas por aqueles que usufruíram deste investimento. 
desvendar as contradições e paradigmas que se estabelecem no mundo da educação, os conflitos que marcam a realidade dos profissionais desta área, assim como os desafios apresentados à escola, colocam-se como inquietações a serem mais especificamente investigadas.

Dedicar-se à investigação da formação do pedagogo em campo específico de atuação é também delimitar objetos próprios do campo da ciência pedagógica, que se concretiza por diferentes fenômenos educativos.

Neste sentido, destacamos que a condição legal de se prever a Pedagogia como o lócus de formação docente, do gestor educacional e do pedagogo, enquanto pesquisador no campo do ensino, caracteriza este processo inicial de formação como um problema complexo, a partir das formas pelas quais se efetiva.

A proposta de formação inicial de gestores escolares no âmbito dos cursos de Pedagogia, a partir das diretrizes curriculares dos cursos, se coloca como problema motivador desta pesquisa, articulando-a com as questões que presentes na profissionalidade dos gestores escolares.

Uma das questões mais conflituosas na apresentação das Novas Diretrizes Curriculares Nacionais para os cursos de Pedagogia foi a intenção inicial do Ministério da Educação e do Conselho Nacional de Educação em destinar o curso exclusivamente à formação docente. Este fato além de reduzir a potencialidade dos saberes pedagógicos, desconsidera significativamente 0 papel da Pedagogia na discussão, reflexão e compreensão dos elementos constituintes dos processos de ensino, aprendizagem e produção do conhecimento em suas diferentes manifestações e possibilidades.

Esta maneira de conceber o curso de Pedagogia se coloca como uma compreensão contraditória da ciência da educação como campo de produção do conhecimento acerca de diversas questões do fenômeno pedagógico e do próprio processo educativo que não pode prescindir de sujeitos que atuem em ofícios não docentes, mas fundamentados nos saberes pedagógicos. 
Tal perspectiva apóia as idéias de Pimenta (2001) ao reiterar que a formação do pedagogo não pode prescindir da compreensão de uma epistemologia que permita a compreensão da Pedagogia como uma das manifestações humanas mais complexas, não se restringindo, portanto à atividade docente.

Nesta proposição, há o convite para investigar a forma que é adotada nos cursos de Licenciatura em Pedagogia para a formação desta identidade tríplice: os docentes, os pesquisadores em educação e os pedagogos em seus diversos campos de atuação, que se definiriam pela compreensão acerca da especificidade do que vem a ser Pedagogia, enquanto campo científico da educação.

Historicamente, o curso de Pedagogia no país, de forma sistematizada, surge em 1939 na Universidade do Brasil, período no qual a discussão pedagógica ganhava importância, assim como as questões socioeconômicas, então no contexto do Estado Novo, com intensas mudanças do padrão de gestão da sociedade. À época, o curso de Pedagogia apresentava uma organização bacharelesca, que não se destinava à formação dos docentes, devendo ser complementada em um ano posterior, popularmente chamado de curso $3+1$, como forma seqüencial de complementação do curso inicial.

Já na década de 1960, com o crescente movimento de endurecimento político nacional, o curso de Pedagogia passa por reformulações nas instituições superiores, até culminar na edição do Parecer CFE 252/69, que promoveu a extinção da condição de bacharelado no curso e estabeleceu a criação das habilitações para a atuação docente ou para as diferentes áreas dos especialistas.

Nas décadas que se sucederam, isto é, 1970, 1980 e 1990, também se estendeu o debate sobre como o curso de Pedagogia sofreria impactos da necessidade nacional da profissionalização de professores, sendo este considerado como espaço de formação não apenas de professores, mas de especialistas em educação. 
Desta maneira, ampliou-se as opções de formação dos supervisores, orientadores, diretores e coordenadores, gerando profunda ruptura entre a formação dos docentes e a dos especialistas em educação, já que previa a organização específica dos cursos de Pedagogia para o exercício em áreas determinadas, como se os saberes da ciência da educação fossem excludentes entre si, como foi ocasionalmente disposto no Parecer CFE 70/76 ${ }^{4}$, que regulamentou esta concepção e proposta.

Mais recentemente, no caso dos anos 1980, detectamos que o impacto do processo de redemocratização do país ou a ruptura com a ditadura política, também representou uma nova abertura das discussões sobre a organização da formação dos profissionais da Educação. Em 1983, foi publicado o Documento de Belo Horizonte, que propunha a reformulação das diretrizes para a formação do pedagogo, proposto pela Comissão Nacional de Reformulação dos Cursos de Formação de Educadores (CONARCFE).

Ao final da década de 1980, após três encontros nacionais, a comissão - CONARCFE - transforma-se na Associação Nacional pela Formação de Educadores (ANFOPE), que teceria severas críticas à constituição e faria propostas de formação dos educadores, sustentando que o foco, quase isolado na formação para a docência, empobreceria a investigação da ciência pedagógica e a discussão de seus saberes constituintes na formação de tais profissionais. Fato que fortaleceria a intensa reivindicação, por parte dos pesquisadores e cientistas da educação, de uma reformulação das diretrizes curriculares para a formação do pedagogo no país.

\footnotetext{
${ }^{4}$ Este Parecer é homologado sob a orientação da LDB 5692/71, que dentre outras alterações, previa a obrigatoriedade para o ensino de $1^{\circ} \mathrm{grau}$, então constituído de 8 anos, o antigo ginásio e primário, que passou a ser uma "escola juntada"; e criava o $2^{\circ}$ grau, que teria ênfase também em habilitações técnicas. O aumento da rede física de atendimento aos alunos provocou a necessidade de aumento de professores habilitados em disciplinas específicas e de profissionais para administrarem as escolas, e os sistemas de ensino. Toda esta situação culminou na proliferação, em muitos casos desqualificada, de instituições de ensino superior por todo o país, sobretudo nas regiões econômica e demograficamente mais densas.
} 
A década de 1990 significou, no campo da política nacional, o período da redefinição do papel do Estado ${ }^{5}$ em diversas áreas da gestão nacional, não obstante a função que Ihe caberia na organização do sistema educacional brasileiro.

Desde o início de 1990, foram muitas as manifestações do Conselho Federal de Educação ${ }^{6}$, no sentido de renovar a legislação educacional. Contudo, o que não aconteceu de fato, dado que o desafio principal se assentava na solidificação de sua expansão qualitativa no país, na flexibilização de processos organizativos da educação, na alteração do padrão de qualidade e meios de financiamento da educação, aproximando o sistema educacional das demandas do setor produtivo, o que culminaria na publicação da atual Lei de Diretrizes e Bases da Educação Nacional (LDBEN), Lei 9394/96.

A partir da citada LDBEN, os debates não se vincularam unicamente às questões de foro estrutural, relacionados aos requisitos de ingresso e conclusão, composição curricular ou competência de atendimento no que diria respeito à Educação Básica, mas também à proposta de formação dos profissionais da educação que nela atuariam, fosse no campo da docência (como previa seu artigo 62) ou nas atividades de gestão da educação (no caso do artigo 64).

Este movimento de atenção com os cursos de formação de pedagogos passa a dedicar intenso cuidado com os caminhos que ganharia esta

\footnotetext{
${ }^{5} \mathrm{Na}$ obra Os desafios da Educação no Brasil, da Editora Nova Fronteira, organizado por Simon Schwartzman, é apresentado panoramicamente o movimento evolutivo da educação brasileira, principalmente no que se refere aos indicadores de atendimento, fluxos escolares, taxas de escolaridade bruta e líquida, concluindo com o impacto deste cenário sobre as mudanças de gestão da educação, que foram eleitas como necessárias, pelo Estado, sobretudo a partir da década de 1990.

${ }^{6}$ Nomenclatura esta que a partir da década de 1990, sob a vigência da lei 9394/94, passa a ser Conselho Nacional de Educação não sendo, porém, esta alteração apenas uma questão de ordem semântica, mas de concepção de política educacional e das lógicas que passariam a ser concebidas como organizadoras do sistema de ensino, atribuindo a este órgão uma função de normatização nacional, e não mais densamente de controle, à vista do poder deliberativo que à época é atribuído aos Conselhos Estaduais de Educação, que se tornam responsáveis pela regulamentação dos sistemas de ensino.
} 
profissionalização, atentando não apenas para a dimensão conceitual, que comporia a matriz curricular do curso, mas, sobretudo, aos aspectos de natureza conjuntural como o perfil desejado para os egressos dos cursos de Pedagogia, o conjunto mínimo de horas necessárias para o atendimento do perfil necessário à formação do pedagogo, o sentido da formação deste profissional não se restringindo ao campo de atuação docente, dentre outros aspectos.

Em março de 2005, foi concluída uma primeira minuta do texto que originaria as novas Diretrizes Curriculares do Curso de Pedagogia. Entretanto, diante de muitos dilemas, reivindicações e debates que se acaloravam em torno da proposta fundamentalmente voltada à formação do pedagogo como docente, o então Ministro da Educação Fernando Haddad, reenviou, no final de 2005, ao Conselho Nacional de Educação, a minuta da Resolução CP CNE 01/06 para a devida inclusão da competência atribuída ao curso de Pedagogia, incluindo a formação dos gestores educacionais - até então chamados de especialistas - que na conformidade do artigo 64 da LDBEN tivera alterada esta nomenclatura, no texto do legislador:

A formação dos profissionais da educação para administração, planejamento, inspeção, supervisão e orientação educacional para a Educação Básica, será feita nos cursos de graduação em Pedagogia ou em nível de pós-graduação, a critério da instituição de ensino, garantida, nesta formação, a base nacional comum (Lei Federal 9394/96 - Artigo 64).

O fato de se extinguir a validade do Parecer CFE 252/69, que regulamentava as antigas habilitações, significou o avanço no campo da compreensão da integralidade da atuação do pedagogo que, entretanto, como medida isolada, não se faria suficiente instrumento para a satisfação da formação e a relação com o campo de atuação profissional.

Stenhouse (1987), Liston \& Zeichner (1993), Geraldi, Fiorentini e Pereira (1998), Pimenta (2002) e Franco (2007), dentre outros, já afirmavam que a formação dos profissionais da educação precisa ser organizada a partir 
de princípios de investigação das suas práticas, de intencionalidade da sua proposta organizativa e de fundamentos que prezem pela intelectualidade.

Algo em comum nas proposituras destes pesquisadores é o reconhecimento da capacidade de reflexão decorrente do exercício da crítica, na medida em que os sujeitos se conscientizam sobre sua atuação profissional, estabelecendo juízo de valor ao reconhecer o caráter dialético e dialógico que deve caracterizar sua ação, não meramente prática, mas circunstanciada também pela intelectualidade.

Está claro que o advento das Diretrizes do Curso de Pedagogia reforçou a necessidade da definição de como se organizaria a estrutura dos cursos de Pedagogia. Estes, doravante, passariam a ter uma estrutura que contemplaria a formação dos docentes para a educação infantil e os anos iniciais do ensino fundamental, o desenvolvimento de competências para a formação investigativa do professor e, conjuntamente, a formação dos profissionais do magistério que não atuam exclusivamente na docência; fato este que a literatura especializada viria a convencionar como "profissionais da gestão educacional" (LIBÂNEO, 2002; RANGEL, 2003; FRANCO, 2008; OLIVEIRA \& ROSAR, 2008).

Se por um lado, ocorre um movimento intenso de discussão acerca da "nova" configuração dos cursos de Pedagogia; por outro, se evidencia uma série de divergências acerca de qual seria o papel dos cursos de Pedagogia e como se colocariam frente à necessidade de formação dos pedagogos.

O palco das divergências, com destaque aos primeiros anos da década de 1990, coloca em xeque a formação enfaticamente voltada à docência, como viria a defender o Ministério da Educação e o Conselho Nacional de Educação ${ }^{7}$, além de educadores como Guiomar Nano de Mello e Eunice Ribeiro Durhan.

\footnotetext{
${ }^{7}$ Registramos, como relevante, que sob a gestão política do PSDB, no país, e fortemente no estado de São Paulo, tivemos alto investimento nos processos de municipalização do ensino, na implantação de mecanismos de avaliação externa da escola, inclusive com práticas de "rankiamento", início da expansão dos cursos baseados no uso de tecnologia para ocorrerem à distância, acomodação das políticas educacionais brasileiras à agenda do Banco
} 
Outros educadores defendiam que a formação do pedagogo deveria basear-se no objetivo de formá-los como pesquisadores da educação, como apresentou o Manifesto dos Educadores Brasileiros, no qual eram signatários Selma Garrido Pimenta, José Carlos Libâneo, José Cerchi Fusari, Maria Amélia Santoro Franco, dentre outros; ou ainda, uma formação que abrangesse também os saberes e elementos para a formação dos demais profissionais do magistério, concepção defendida por inúmeras associações como ANPAE, ANPED, ANFOPE, FORUMDIR e FONAPE, além de educadores como Helena de Freitas e Márcia Ângela Aguiar.

Enfatize-se, ainda, que mesmo no plano das discussões da academia, dos pesquisadores da educação e dos movimentos organizados em torno da discussão das novas diretrizes para o curso de Pedagogia, ou mesmo para a identidade do pedagogo, eram vários os consensos e dissensos, que tornavam quase impossível concluir um projeto aglutinador, ao menos naquele momento, como podemos notar por um dos trechos do Manifesto dos Educadores Brasileiros, de setembro de 2005:

Em seu exercício profissional, o pedagogo estará habilitado a desempenhar atividades relativas à: formulação e gestão de políticas educacionais; avaliação e formulação de currículos e de políticas curriculares; organização e gestão de sistemas e de unidades escolares; coordenação, planejamento, execução e avaliação de programas e projetos educacionais, para diferentes faixas etárias (criança, jovens, adultos, terceira idade); formulação e gestão de experiências educacionais; coordenação pedagógica e assessoria didática a professores e alunos em situações de ensino e aprendizagem; coordenação de atividades de estágios profissionais em ambientes diversos; formulação de políticas de avaliação e desenvolvimento de práticas avaliativas no âmbito institucional e nos processos de ensino e aprendizagem em vários contextos de formação; produção e difusão de conhecimento científico e tecnológico do campo educacional; formulação e coordenação de programas e processos de formação contínua e desenvolvimento profissional de professores em ambientes escolares e não-escolares; produção e otimização de projetos destinados à educação a distância, programas televisivos, vídeos educativos; desenvolvimento cultural e artístico para várias faixas etárias. A formação de professores para a educação infantil e anos/ciclos iniciais do Ensino Fundamental, se dará em cursos específicos de licenciaturas, a serem oferecidos nas Faculdades/Centros/Departamentos de Educação e regulamentados pelas já existentes Resoluções 01 e 02/02 do CNE. A formação de professores para os anos finais do Ensino Fundamental e para o Ensino Médio, também regulamentada pelas citadas Resoluções, será oferecida nas Faculdades/Centros/Departamentos de Educação em parceria com os institutos de conteúdos específicos (Manifesto do Educadores Brasileiros,2005).

Interamericano de Desenvolvimento (BID), precarização das condições de trabalho em grande parte das universidades públicas, inclusive com o êxodo de muitos docentes de referência. 
Este movimento intelectual de cunho político e repleto de contradições e antagonismos desenvolveu-se como fruto da normatização, uma vez que notadamente a Resolução CNE CP 01/06 tratou com pouca circunscrição a carga horária necessária à formação dos profissionais no curso de Pedagogia, deixando sua regulamentação por conta das instituições superiores que viessem a oferecer o curso. Apesar disso demonstrou um avanço relativo na preocupação de articular a dimensão teórica, obtida na formação inicial do pedagogo, e sua implicação nos possíveis encaminhamentos profissionais vinculados à atuação do pedagogo, como podemos inferir pelo texto legal:

Art. $7^{\circ} \mathrm{O}$ curso de Licenciatura em Pedagogia terá a carga horária mínima de 3.200 horas de efetivo trabalho acadêmico, assim distribuídas:

I - 2.800 horas dedicadas às atividades formativas como assistência a aulas, realização de seminários, participação na realização de pesquisas, consultas a bibliotecas e centros de documentação, visitas a instituições educacionais e culturais, atividades práticas de diferente natureza, participação em grupos cooperativos de estudos;

II - 300 horas dedicadas ao Estágio Supervisionado prioritariamente em Educação Infantil e nos anos iniciais do Ensino Fundamental, contemplando também outras áreas específicas, se for o caso, conforme o projeto pedagógico da instituição;

III - 100 horas de atividades teórico-práticas de aprofundamento em áreas específicas de interesse dos alunos, por meio, da iniciação científica, da extensão e da monitoria (Resolução CNE CP 01/06 - Artigo 7)

No panorama recente do curso de Pedagogia no Brasil, principalmente a partir dos anos de 2000, identificamos a relevância de nos dedicarmos à investigação de quais as propostas presentes no âmbito do currículo dos cursos e o lugar da formação dos gestores educacionais, previsto na Pedagogia a partir da Lei 9394/96 e da Resolução CNE CP 01/06 (chamados de especialistas da educação), levando em conta sua condição para contribuir com o desenvolvimento profissional dos gestores escolares, como concepção de formação e atuação desses profissionais, a partir do contexto de sua profissionalidade.

O que pretendemos, nesta pesquisa, é demonstrar que a própria formação dos gestores escolares, no curso de Pedagogia, precisa ser analisada a partir de diferentes fontes investigativas, algo que se faz necessário devido à situação decorrente dos conflitos entre os cursos de formação e os contextos reais sob os quais atuam. Assim, ficam definidos como objetivos desta pesquisa: 
1. Resgatar o histórico do curso de Pedagogia no Brasil e sua relação com a formação dos diferentes campos de atuação do pedagogo;

2. Apontar o panorama legal contemporâneo que sustenta o curso de Pedagogia e a formação dos gestores escolares;

3. Identificar e discutir o conceito de gestão que tem predominado nos cursos de formação e no próprio repertório educacional;

4. Discutir a coerência entre o conceito de gestão propalado nos cursos de formação, na legislação e o que os profissionais que atuam efetivamente nestas atividades apontam, considerando seu trabalho na rede pública;

5. Analisar as propostas de formação para gestores escolares nos atuais cursos de Pedagogia;

6. Investigar a coerência da estrutura proposta pelos cursos atuais de Pedagogia e as expectativas que têm sido destinadas a esta formação no caso dos gestores escolares;

7. Indicar as contradições e dilemas que estão presentes nos cursos de Pedagogia quando se trata da finalidade de formação de gestores escolares;

8. Apontar mudanças que podem ocorrer no curso de Pedagogia para que possam ser ampliadas as contribuições desta formação e atuação destes profissionais.

Como ressalta Gadotti (2006), este entendimento da realidade na qual se constroem as práticas no campo da educação e, portanto, de pesquisa educativa, se contrapõe às perspectivas baseadas na racionalidade técnica e reconhece o caráter dialético que deve ser indicado pela educação: 
A educação aparece então num conjunto de conexões internas e externas. Não é mais vista, por exemplo, como uma relação interna bipolar entre professor e aluno, mas é entendida como momentos e aspectos contraditórios de um movimento mais amplo da própria sociedade, uma totalidade na unidade dos contrários. A educação hoje está se repensando a partir de outra concepção que os educadores estão dentro dela: longe de ser um lugar imutável. Ela está sendo descoberta como um local provisório, inacabado, precário, prolongamento de uma sociedade. E descobrindo sua precariedade abre-se para o profissional do ensino uma situação extremamente desconfortante, conflitante (GADOTTI, 2006, p. 169).

Corroboramos o entendimento de que, como o fenômeno educativo, a formação dos gestores escolares é tão somente relacionada a esta dimensão da profissionalidade do pedagogo à organização do trabalho nas escolas, considerando sua complexidade, contextos e contradições, uma maneira de reconhecer que se trata de uma investigação pedagógica, pois implica na aproximação do sentido epistemológico, social e político do campo educativo.

Com efeito, pesquisar a dimensão teórica da formação profissional e seus fundamentos científicos e, ao mesmo tempo, práticos, não apenas acena para a produção de novos saberes sobre a ciência da educação, mas também qualifica o fazer pedagógico, já que o coloca como objeto central desta ciência.

Nas palavras de Franco (2008), a ciência pedagógica, e conquanto a pesquisa que dela (e nela) deriva, é uma ação eminentemente de vertente política e ideológica, inclusive por implicar em questões que contribuem para a organização e compreensão acerca do trabalho pedagógico:

\begin{abstract}
A Pedagogia, para poder dar conta de seu papel social, deverá definir-se e exercer-se como ciência própria, que liberta dos grilhões de uma ciência clássica e da submissão às diretrizes epistemológicas de suas ciências auxiliares, a fim de que possa se assumir como uma ciência que não apenas pensa e teoriza questões educativas, mas que organiza ações estruturais, que produzam novas condições de exercício pedagógico, compatíveis com a expectativa emancipatória de sociedade (FRANCO, 2008, p.73).
\end{abstract}

Ainda de acordo com a pesquisadora, é fundamental reintegrarmos o fenômeno educativo ao pedagógico, algo que não pode prescindir da definição de procedimentos próprios da investigação pedagógica, tornando-a menos 
dependente de ciências auxiliares, que minimizam o valor da práxis educativa como objeto principal da ciência da educação.

Assim, defendemos que ao articular a historicidade do curso de Pedagogia, as formas de organização curricular propostas e sua relação com os fazeres profissionais dos que atuam nas atividades de gestão escolar ${ }^{8}$, apontamos para a idéia de educação compreendida como prática social, que se fundamenta em saberes pedagógicos, desenvolvidos no cotidiano do trabalho, mas também nos processos de formação profissional, seja este inicial ou continuado.

Por considerar este objeto de investigação como determinante, esta pesquisa terá como foco central o levantamento de elementos do ponto de vista da organização curricular dos cursos de Pedagogia, bem como sua relação com o que ficou anunciado nos documentos legais como bases formativas para o pedagogo e para o que, nesta pesquisa, nos interessa diretamente, no que diz respeito aos gestores escolares.

Complementarmente, a análise sobre as propostas de formação dos gestores escolares se voltará para a identificação de elementos do curso de Pedagogia que possam contribuir para a atuação dos profissionais numa perspectiva de desenvolvimento profissional e institucional nas escolas, a partir das concepções trazidas principalmente por Almeida (1999), Garcia (1999), Day (2001), Fullan \& Hargreaves (2001) e Lima (2002), tendo como referência a desenvolvimento de sua própria profissionalidade.

Consideramos a perspectiva de desenvolvimento profissional e institucional, para analisar como estes profissionais descrevem a realização de seu próprio trabalho, compreende a formação e a atuação articulada aos contextos práticos da escola e aos conhecimentos teóricos da educação

\footnotetext{
${ }^{8}$ Como referência, podemos citar que várias pesquisas desenvolvidas, por exemplo, na FE USP, sob a autoria de estudiosos como Anita Fávaro Martelli e João Gualberto Carvalho de Meneses (década de 1970), Eleny Mitrullis, Beatriz Alexandrina de Moura Fétizon (década de 1980), Lisete Regina Gomes Arelaro, José Cerchi Fusari e Vitor Paro (a partir de 1990, principalmente), nos aproximam da histórica discussão sobre o trabalho dos administradores escolares ou responsáveis pelo suporte pedagógico e organização da escola, o que chamamos aqui de gestão escolar.
} 
mediada pela intencionalidade dos sujeitos e pela definição colaborativa de objetivos e percursos de trabalho que priorizem a melhoria qualitativa deste.

A opção por este tipo de análise nos remete ao entendimento de que o desenvolvimento profissional como uma alternativa mais eficaz para a formação dos profissionais se constitui numa das possibilidades de se enfrentar a suposta condição de "semiprofissão" que muitos pesquisadores atribuem aos professores, em virtude da ausência de mecanismos próprios de controle dos padrões profissionais, além de não terem, neste sentido, propriamente uma identidade coletiva, em virtude dos mecanismos de controle aos quais são submetidos.

\section{Da definição do corpus da pesquisa}

A definição do corpus desta pesquisa apoiou-se na constatação de que há relativa escassez na produção de estudos que tenham como objetivo central a análise das propostas de formação dos gestores escolares, no plano da organização dos cursos de Pedagogia.

Pretende-se, portanto, destacar este viés formativo previsto nas Diretrizes Curriculares da Pedagogia para a organização dos cursos, contrapondo-a às necessidades reais de atuação na perspectiva do desenvolvimento profissional e institucional na escola, com foco nas instituições públicas, considerando o sentido político e social de garantia de uma educação verdadeiramente democrática.

Esta constatação preliminar não poderia prescindir de fundamentos concretos acerca da produção acadêmica neste campo de trabalho do pedagogo, assim fez-se necessário um levantamento ${ }^{9}$, ainda que preliminar,

\footnotetext{
${ }^{9}$ Em seu trabalho, ANDRÉ, Marli et al. Estado da arte na formação de professores no Brasil (1999), apresenta um exemplo do que chamamos de procedimento de Estado da Arte, ou seja, um levantamento qualitativo de toda a produção acadêmica acerca de um tema, de modo que a pesquisa ou estudo para qual nos dedicamos não seja objeto de superposição sobre algo já existente. Neste sentido, trata-se de um procedimento de definição do corpus, e comparação do mesmo com um conjunto consideravelmente amplo de trabalhos, detectando o foco do
} 
das produções que contemplam o problema central delimitado pela presente pesquisa.

Para a definição do problema central da pesquisa, realizamos um levantamento junto ao Banco de Teses da CAPES acerca da produção de pesquisas sobre a gestão educacional, a partir do acervo bibliográfico já constituído sobre o mesmo tema nos últimos sete anos (2004-2010). Pesquisamos tanto em Instituições de Ensino Superior públicas quanto privadas, com programas credenciados de pós-graduação, adotando o seguinte procedimento para tal:

a) Utilizando, no comando de busca da referida plataforma, as palavras "gestão escolar", "curso de pedagogia", "direção", “coordenação", "supervisão" e "orientação educacional", constatamos que os 1349 trabalhados que se aproximam do tema se ramificam em diferentes focos de pesquisa acerca dos vários aspectos da gestão escolar, educacional, ou mesmo da profissionalidade dos gestores educacionais, como podemos constatar pelo quadro de focos mais reincidentes nas pesquisas:

\section{Distribuição das pesquisas sobre Gestão Escolar nos 07 anos (2004-2010)}

\begin{tabular}{|l|l|l|l|l|l|l|l|l|}
\hline Trabalho/Anos & $\mathbf{2 0 0 4}$ & $\mathbf{2 0 0 5}$ & $\mathbf{2 0 0 6}$ & $\mathbf{2 0 0 7}$ & $\mathbf{2 0 0 8}$ & $\mathbf{2 0 0 9}$ & $\mathbf{2 0 1 0}$ & Total \\
\hline Dissertações & 187 & 178 & 228 & 207 & 149 & 137 & 141 & 1227 \\
\hline Teses & 10 & 13 & 20 & 18 & 22 & 19 & 20 & 122 \\
\hline Total & 197 & 191 & 248 & 225 & 171 & 156 & 161 & 1349 \\
\hline
\end{tabular}

Banco de Dados CAPES 2011

tratamento que Ihe foi dado. Utilizando este procedimento inicial de pesquisa podemos constatar a inexistência, escassez, ou excesso de trabalhos que tenham se dedicado a investigação de um tema, ainda que por meio de diferentes metodologias de investigação, ou abordagens mais qualitativas ou quantitativas. 
b) Inicialmente, rastreamos as dissertações e teses que se dispuseram a tratar da investigação das questões educacionais a partir da perspectiva da "gestão escolar", tendo localizado aproximadamente 1011 trabalhos. Em muitas destas pesquisas, a gestão escolar ou os profissionais que a desenvolvem não se caracterizaram como foco, mas como elemento complementar e integrante do estudo;

c) Em seguida, refinamos a pesquisa a partir das referências mais específicas ao trabalho da "coordenação, direção ou supervisão", quando então, pudemos identificar cerca de mais 459 trabalhos publicados na plataforma. Destaca-se que, neste recorte, um volume expressivo de pesquisas se configura como trabalhos que investigaram o ofício de determinado segmento profissional ou, ainda, a atuação destes, diante de programas, projetos ou determinadas situações-problema da escola.

Entretanto, para apurar as produções científicas de convergência com esta pesquisa, nos detivemos neste grupo de trabalhos, pois a partir da leitura de seus resumos, constatamos que priorizavam mais especificamente a profissionalidade ou profissionalização dos gestores escolares. Neste caso, pudemos constatar que as produções estavam subdivididas a partir de seus enfoques:

Distribuição das pesquisas por foco sobre a Gestão Escolar (2004-2010)

\begin{tabular}{|l|c|c|c|c|c|c|c|}
\hline Assuntos das Produções & $\mathbf{2 0 0 4}$ & $\mathbf{2 0 0 5}$ & $\mathbf{2 0 0 6}$ & $\mathbf{2 0 0 7}$ & $\mathbf{2 0 0 8}$ & $\mathbf{2 0 0 9}$ & $\mathbf{2 0 1 0}$ \\
& M - D & M - D & M - D & M - D & M - D & M - D & M - D \\
\hline $\begin{array}{l}\text { Gestão da Escola e } \\
\text { Tecnologia }\end{array}$ & $05-00$ & $04-00$ & $01-01$ & $02-00$ & $01-00$ & $03-01$ & $03-00$ \\
\hline $\begin{array}{l}\text { Gestão da Escola e Qualidade } \\
\text { em Educação }\end{array}$ & $06-00$ & $03-00$ & $04-01$ & $05-01$ & $05-00$ & $04-01$ & $04-01$ \\
\hline $\begin{array}{l}\text { Gestão Democrática e } \\
\text { Colaborativa }\end{array}$ & $14-03$ & $10-02$ & $06-01$ & $08-02$ & $05-02$ & $03-01$ & $05-01$ \\
\hline $\begin{array}{l}\text { Gestão e Projeto Político } \\
\text { Pedagógico }\end{array}$ & $10-01$ & $07-01$ & $06-02$ & $07-00$ & $05-03$ & $04-01$ & $06-01$ \\
\hline
\end{tabular}




\begin{tabular}{|l|c|c|c|c|c|c|c|}
\hline $\begin{array}{l}\text { Papel e Práticas da } \\
\text { Coordenação Pedagógica }\end{array}$ & $03-00$ & $03-01$ & $07-01$ & $04-00$ & $07-02$ & $06-02$ & $06-02$ \\
\hline $\begin{array}{l}\text { Formação do Orientador } \\
\text { Educacional }\end{array}$ & $01-00$ & $00-00$ & $00-00$ & $00-01$ & $00-00$ & $01-00$ & $00-00$ \\
\hline $\begin{array}{l}\text { Gestão e Relação de Poder na } \\
\text { Escola }\end{array}$ & $03-00$ & $02-01$ & $03-01$ & $03-00$ & $03-01$ & $02-00$ & $02-00$ \\
\hline $\begin{array}{l}\text { Registro das Práticas da } \\
\text { Gestão na Escola }\end{array}$ & $01-00$ & $00-00$ & $01-00$ & $01-00$ & $01-00$ & $01-01$ & $01-00$ \\
\hline $\begin{array}{l}\text { Gestão de Práticas de } \\
\text { Formação Contínua }\end{array}$ & $04-02$ & $05-00$ & $08-01$ & $05-00$ & $04-00$ & $04-00$ & $04-00$ \\
\hline $\begin{array}{l}\text { Representaçães sobre a } \\
\text { Supervisão }\end{array}$ & $01-00$ & $01-02$ & $00-02$ & $00-02$ & $01-00$ & $01-00$ & $03-00$ \\
\hline $\begin{array}{l}\text { Formação Continuada para os } \\
\text { Especialistas }\end{array}$ & $03-00$ & $02-00$ & $03-01$ & $02-00$ & $05-01$ & $04-00$ & $05-00$ \\
\hline $\begin{array}{l}\text { Gestão, Formação Continuada } \\
\text { e Ciclos }\end{array}$ & $03-00$ & $02-01$ & $04-00$ & $04-00$ & $02-00$ & $03-01$ & $04-01$ \\
\hline Papel da Supervisão Escolar & $03-00$ & $02-01$ & $02-01$ & $05-01$ & $01-00$ & $02-01$ & $01-00$ \\
\hline Gestão e Inclusão na Escola & $01-00$ & $02-00$ & $04-00$ & $04-01$ & $05-02$ & $04-01$ & $04-02$ \\
\hline $\begin{array}{l}\text { Papel da Direção e Formação } \\
\text { Contínua }\end{array}$ & $05-00$ & $03-00$ & $03-01$ & $03-00$ & $02-00$ & $03-00$ & $02-00$ \\
\hline Gestão da Escola e Avaliação & $03-00$ & $04-00$ & $03-01$ & $04-01$ & $02-00$ & $04-01$ & $01-01$ \\
\hline Perfil da Direção Escolar & $05-00$ & $03-00$ & $02-00$ & $02-01$ & $02-00$ & $02-01$ & $02-00$ \\
\hline Total & $\mathbf{7 1 - 0 6}$ & $\mathbf{5 4 - 0 9}$ & $\mathbf{5 5 - 1 4}$ & $\mathbf{5 9 - 1 0}$ & $\mathbf{5 1 - 1 1}$ & $\mathbf{4 7 - 1 2}$ & $\mathbf{5 3 - 0 9}$ \\
\hline Totais por nível de pesquisa & & & & & & & $\mathbf{3 9 0}$ \\
\hline
\end{tabular}

Banco de Dados CAPES 2011

d) Em que pese o período de sete anos que delimitamos para este procedimento de busca, este levantamento nos possibilitou apresentar algumas considerações preliminares:

- embora o número de pesquisas que levantamos acerca de trabalhos que anunciam, de certo modo, a gestão escolar como um de seus elementos, num curto período de tempo, há uma incidência pouco expressiva de trabalhos que a tenham como foco, ou ainda, desvelando sua própria identidade profissional, posto como a relação da formação e suas formas de atuação;

- encontramos dentre os trabalhos inúmeras produções que tratam o tema da gestão como um aspecto paralelo do trabalho e não como foco da 
discussão, a exemplo: a indisciplina na escola (e o que fazem os gestores), currículos escolares (e atuação de coordenadores); a formação docente nas Diretrizes Curriculares Nacionais para o curso de Pedagogia (também formando gestores); educação indígena ou étnico racial (e o que cabe aos gestores); metodologias de ensino na escola ou programas (e a contribuição dos diretores ou coordenadores); questões de financiamento (e organização da escola); e avaliação de experiências relacionadas em determinados programas institucionais (Progestão, PROFA, TV Escola, Educação a Distância);

- quando se trata da gestão escolar como atividade, o volume de trabalhos é bem maior do que as pesquisas que investigaram a profissionalidade característica de cada um dos ofícios, algo que demonstra uma preocupação mais evidente com as atividades, que de certo modo, representam práticas generalistas no trabalho destes pedagogos com os conhecimentos pelos quais os sujeitos desenvolvem tais ofícios;

- mesmo quando consideramos o número de trabalhos sobre a gestão escolar e os próprios gestores, a definição mais específica dos temas das pesquisas demonstram que estes trabalhos estão dedicados à análise da atuação destes sujeitos com determinados aspectos do ofício, ou mesmo a determinados pontos problemas estabelecidos como centrais, principalmente em relação ao contexto da escola, e não necessariamente dedicando-se a investigação sobre a própria identidade ${ }^{10}$ dos gestores escolares, como ofício de pedagogos na escola, como por exemplo: pesquisas sobre coordenadores centradamente dedicadas à formação contínua ou determinados projetos;

${ }^{10}$ Claude Dubar (1997), em sua obra "A socialização: construção das identidades sociais e profissionais", defende que a identidade é um conceito e uma representação construída social e pessoalmente e, por isso, é instável e provisória, objetiva e subjetiva, coletiva e individual, biográfica e conjuntural, ou seja, é um conjunto de processos que formam o modo de ser, pensar, agir dos sujeitos e dos coletivos. Neste sentido, o pesquisador entende que a identidade não é concebida ou pronta, mas construída e modificada, numa situação cujas características apresentam mutabilidade em mais ou menos tempo. Partindo destes pressupostos, a identidade vai se construindo pelas características pessoais que integram $o$ "eu" de cada pessoa e, ao mesmo tempo, agrega aspectos da cultura, da vida e do mundo às experiências pelas quais vão passando, logo, não é possível concebermos quaisquer tipos de identidade igual, ainda que em diferentes situações e espaços. 
pesquisas sobre diretores, enfatizando a gestão democrática ou participativa, ou ainda práticas experimentais; e sobre a supervisão escolar e a lógica de poder na escola;

- constatamos uma concentração de trabalhos que se dedicaram ao estudo da epistemologia da prática dos gestores educacionais, sem, contudo, priorizarem os elementos da cultura do trabalho (e constitutivos) que orientam o que estes profissionais fazem e sua relação com a própria formação da qual se originam;

- não identificamos trabalhos que tratem da interação entre a concepção de formação do gestor escolar trazida pelos dispositivos legais, a forma pela qual tem se apresentado esta formação inicial e, principalmente, apreciando estes elementos à luz de uma determinada perspectiva de atuação em relação ao trabalho na escola. Há alguns trabalhos pontuais que indicam 0 desenvolvimento profissional como uma concepção de melhoria do trabalho para os professores, a ser implementado pelos gestores. No entanto, a maioria dos trabalhos, em que pese sua relevância, tratam da gestão escolar numa perspectiva de contribuição para uma determinada finalidade pedagógica ou mesmo organizativa.

e) Pesquisas de referência: ao concluir o presente levantamento, identificamos doze trabalhos deste período (dentre dissertações e teses) que poderão contribuir especificamente para a investigação a qual se dedica esta pesquisa. Assim, agrupamos os trabalhos em cada um dos três grandes campos de aproximação da pesquisa que desenvolveremos: sobre o curso de Pedagogia e as Diretrizes Curriculares - concepção e aspectos legais (3 dissertações e 1 tese); sobre a formação inicial do gestor escolar ( 4 dissertações e 1 tese); e identidade e lógica de trabalho dos gestores implicações sobre a cultura dos profissionais da escola (2 dissertações e 1 tese).

Antecipa-se por este rastreamento que são raros, principalmente, em virtude da recente publicação das Diretrizes Curriculares da Pedagogia, estudos e pesquisas que priorizem a investigação da formação dos 
profissionais até então chamados de "especialistas em educação"11 e mais recorrentemente, nos últimos anos, de "gestores escolares", principalmente no que se refere aos possíveis impactos provocados na profissionalidade ou no profissionalismo dos sujeitos, sobretudo quando se define o conceito de desenvolvimento profissional e institucional como referência de formação e atuação.

De acordo com as afirmações de André (2001) e Freitas (2004), o momento histórico educacional é conflituoso e de proletarização dos profissionais da educação. Entretanto, é extremamente promissor para que retomemos rigorosamente a discussão sobre os objetivos da educação, os conteúdos de formação dos profissionais e os próprios conteúdos escolares, como alternativas para ressignificar o sentido do conhecimento e da prática pedagógica.

\section{Do método da pesquisa}

As contribuições trazidas por Luna (2002) apontam para a necessidade de que a metodologia do trabalho consista na existência de uma pergunta a ser respondida no decorrer da pesquisa, portanto é imprescindível a definição de um conjunto de procedimentos que sejam capazes de agregar elementos para a análise do problema e resposta à pergunta, que precisa garantir um grau significativo de confiabilidade.

11 Brevemente, indicamos que a idéia de "especialistas em educação" e "gestores de educação" ou "gestores escolares", revela inclusive a orientação de trabalho que se deseja para o desenvolvimento das funções ora revestidas ao sujeito. Deste modo, se o conceito de especialistas pode significar determinada restrição acerca dos saberes que tal profissional deveria estar dotado para o trabalho na escola como unidade, o conceito de gestor também apresenta controvérsias em relação à idéia que temos de escola democrática, organizada a partir de procedimentos de desenvolvimento colaborativo, mas tende a uma lógica mais vinculada a dispositivos e técnicas de regulação institucional, como veremos mais aprofundadamente na pesquisa. 
De tal modo, a metodologia do trabalho não trata de uma formalidade científica, centrada em técnicas, mas sim da busca das implicações de determinadas variáveis sobre a configuração do problema da pesquisa e sobre a construção da tese acerca do mesmo.

Para a realização deste trabalho, elegemos a abordagem qualitativa de pesquisa, pois entendemos que esta nos proporciona a articulação metodológica de diferentes fontes, a partir do viés do problema, possibilitando a análise de suas contradições, características e implicações na organização da própria ciência da educação, além do que, não se vale de uma alternativa meramente quantitativa, já que requer apreciação e análise, inclusive através da relação entre o problema teórico da pesquisa, os dados das fontes selecionadas e os sujeitos participantes (GONZAGA, 2006).

Quando definimos esta abordagem para a pesquisa, temos o propósito da reflexão crítica acerca da totalidade possível sobre a formação inicial dos gestores escolares e suas relações com seus fazeres, algo que não se bastaria em um processo comparativo, o que nos remete a este enfoque qualitativo e multirreferenciado, pela diversidade dos elementos para análise.

A pesquisa se dedica à investigação da organização dos cursos de Pedagogia, a partir de um conjunto de dados que permitam identificar e compreender a tendência adotada como formação dos pedagogos que atuam como gestores escolares (ou especialistas em educação) e sua coerência teórico-prática com as demandas da profissionalidade, segundo suas próprias experiências.

A opção por esta concepção metodológica indica também o valor que atribuímos ao cotidiano escolar como espaço no qual os profissionais do magistério constroem sua profissionalidade, enfrentam suas contradições e desenvolvem os saberes dos quais se apropriaram, inclusive na sua formação inicial. 
Embora não seja o elemento central desta pesquisa, concordamos com André (2001) ao valorizar o cotidiano escolar como espaço de concretização das práticas, o que nos move a relacionar as propostas de formação inicial com as formas que os gestores realizam seu trabalho na escola pública ${ }^{12}$, uma vez que neste cenário se concretiza a relação entre o ofício, a profissionalidade e o contexto do trabalho:

\begin{abstract}
A importância do estudo do cotidiano escolar se coloca aí: no dia a dia da escola é o movimento de concretização de uma série de pressupostos subjacentes à prática pedagógica, ao mesmo tempo que é o momento e o lugar da experiência e da socialização que envolve professores e alunos, diretor e professores, diretor e alunos, e assim por diante. Conhecer a realidade concreta desses encontros desvenda, de alguma forma, a função de socialização não manifesta da escola, e ao mesmo tempo em que indica alternativas para que esta função seja concretizada da maneira o mais dialética possível (ANDRÉ, 2001, p.40).
\end{abstract}

Desta forma, embora não se trate de um estudo etnográfico, ou de uma investigação propriamente dita sobre o cotidiano dos gestores escolares, o fato de nos valermos de suas narrativas a respeito de como desenvolvem seu trabalho poderá expressar a forma pela qual organizam seu trabalho, os desafios com os quais se deparam e, portanto, os saberes e as competências que mobilizam na construção de sua profissionalidade, inclusive na relação do que desenvolvem profissionalmente os diferentes profissionais da área da educação.

O desenvolvimento desta pesquisa segue com o objetivo de articular os elementos coletados e as produções teóricas já constituídas acerca das Diretrizes Curriculares do Curso de Pedagogia e da formação dos gestores educacionais, com outras evidências e indicadores que possam demonstrar como efetivamente este processo pedagógico tem ocorrido.

\footnotetext{
${ }^{12}$ Apesar dos gestores escolares serem formados para a atuação tanto na rede pública como privada, elegemos a discussão do papel destes profissionais na escola pública por entendermos que são estas instituições que atendem a maioria da população brasileira, neste caso, elas que, mantidas pelo Estado, têm o dever de garantir o compromisso político com a construção de uma educação de melhor qualidade, de maneira que exista não apenas a democratização de oportunidades, mas também de condições e conquistas educacionais por todos os alunos, e, portanto exige que os cursos de formação de pedagogos priorizem também este compromisso, não apenas pedagógico.
} 
De outra forma, é uma maneira de demonstrar nossa inquietação com aquilo que já é sabido sobre os cursos de Pedagogia e conquanto exigirá procedimentos que sejam capazes de orientar uma outra leitura sobre esta realidade pedagógica, como afirma Corazza (2002):

\begin{abstract}
Por isso, realidade não é uma coisa - uma situação, uma condição, um estado - que possa ser vista, analisada, investigada "no que realmente é", nem existem enunciados sejam mais adequados à esta coisa, ou que a representem de forma mais conveniente, mais pertinente. Assim, não é possível encontrar a verdade na/da realidade, ou a realidade verdade, bem como, não existe a falsa realidade, vista ou falada de determinado ângulo enganoso. Por exemplo, não como querem alguns, "a realidade educacional brasileira", mas tantas realidades, quantas sejam aquelas que podemos enunciar, conhecer, pensar, discutir, disputar sobre o que chamamos aquilo de realidade educacional brasileira, ou não; tantas quantas realidades educacionais brasileiras, quantas as que temos condições históricas, para descrever (CORAZZA, 2002, p.113).
\end{abstract}

O foco desta pesquisa se concentra em um problema complexo, uma vez que se constitui por muitos aspectos da realidade educacional brasileira, tanto pelo fato da diversificação legal normatiza a formação, inclusive a mais recente, como pela dimensão geográfica e social do país que impõe uma imensa variação do trabalho pedagógico, dos desafios e conquistas da escola, e das necessidades de formação e de atuação dos profissionais.

Como defende Ardoino (1998), é a complexidade do fenômeno educativo que se estabelece por uma imensa variação de elementos constituintes, mesmo quando envolve um grupo menor de sujeitos, ou ainda, problemas e contextos de uma realidade mais pontualmente delimitada, que justifica a análise sob ótica diversificada para sua compreensão, o que refuta apenas a aplicação de lógicas mais racionalistas possivelmente insuficientes para sua compreensão, e que inviabilizam o reconhecimento da polissemia existente no âmbito de muitas questões presentes nas pesquisas em educação.

Considerando o contexto de presumível pluralidade das propostas de formação dos gestores escolares, a organização metodológica da pesquisa se 
volta à investigação de como as premissas do campo legal e pedagógico dos cursos se articulam na constituição destes profissionais, sujeitos estes que atuam em determinada perspectiva de trabalho, o que inclusive entendemos, a partir das contribuições de Franco (2008), como sendo uma forma de demonstrar que a formação do pedagogo não se restringe à formação docente, logo, requer que sejam desenvolvidas pesquisas relacionadas a outros campos de sua atuação, que não a docência:

\begin{abstract}
No processo de sua formação, o pedagogo deve construir profunda intimidade com as questões da docência, do ensino, mas será inconcebível subsumir a formação de pedagogos ao exclusivo exercício docente. A tarefa pressuposta ao pedagogo, ou seja, a de ser um pesquisador crítico da práxis educativa, requer uma sofisticada formação; assim como a tarefa de formação de um professor crítico-reflexivo também exige. Mas os focos da formação são diferentes: ao pedagogo, são os processos constituintes e intervenientes na práxis educativa; ao professor, a ênfase está nos processos dialógicos e dialéticos da relação aluno e conhecimento, quer na construção, quer na apropriação desse processo. Focos próximos e complementares diferentes e que requerem olhares, metodologias, procedimentos e preparo diferentes (FRANCO, 2008, p.124).
\end{abstract}

Optou-se, então, pelo tratamento da pesquisa a partir de diferentes instrumentos: textos legais de referência, matrizes curriculares dos cursos de Pedagogia e questionário para especialistas de educação, de modo que investiguemos o movimento contemporâneo dos cursos e da profissão docente, no ofício de especialistas, e que tal atuação é também circunstanciada pelo processo de formação inicial, o que se coloca como uma tentativa de investigação da totalidade do problema, não se restringindo apenas ao foco cientificista.

Com o cenário exposto anteriormente, elegemos a abordagem metodológica multirreferencial, pois entendemos que ela é mais adequada ao propósito desta pesquisa, uma vez que nos baseamos na consideração de diferentes categorias de dados, como uma resposta às abordagens metodológicas mais cartesianas e pragmáticas, e que, por sua vez, passa a considerar mais amplamente a complexidade tanto do objeto ou dos fenômenos pesquisados, como a complexidade dos instrumentos a serem 
utilizados na estruturação metodológica, como um exercício de olhar de maneira menos padronizada para a relação entre sujeitos e processos.

Neste sentido, a multirreferencialidade deriva tanto de uma concepção epistemológica, neste caso, acerca dos fenômenos educativos, quanto de uma abordagem metodologicamente mais diversa que permite olhar por diversos ângulos determinados processos, fatos, ou fenômenos educativos complexos, de maneira também profundamente rigorosa.

Como propõe Barbier (1985), nesta abordagem metodológica, o sujeito não se limita às suas percepções para a análise dos processos, mas identifica no contexto interior e exterior da investigação, elementos diferenciados que podem ser contribuintes para a pesquisa, uma vez que a escola constitui-se como espaço altamente complexo. Espaço este que demonstra profundas contradições, como, por exemplo, a existência, ao mesmo tempo, de sistemas consideravelmente refinados de avaliação ou coletas de dados por meio tecnológicos, em oposição a escolas ainda em funcionamento precário, nas quais chega a faltar giz e lousa, agravando os inaceitáveis índices de analfabetismo, ou de adesão à profissão docente.

Na verdade, como concebem Ghedin \& Franco (2006), não se trata de reduzir o valor e o sentido da ciência na pesquisa sobre os fenômenos pedagógicos, mas reconhecer que "ela", isoladamente, sem a devida articulação entre sujeito e objeto, não nos levaria a compreender a totalidade dos problemas educacionais que são investigados, tanto no campo da atuação, como no campo da formação:

Sujeito e objeto não são só relação, mas condição sine qua non da produção do conhecimento. Por conta disso, o conhecimento deve, cada vez mais, buscar uma compreensão da realidade, e não somente as suas particularidades objetivas ou subjetivas. Não estamos negando a importância do sujeito que conhece, apenas queremos afirmar que sozinhos não somos suficientes para fazer compreender o ser do mundo e no mundo. Todo saber deve se buscar na direção da totalidade, para que se aproxime de sua verdade. Isso quer dizer que na nossa busca é sempre aquele que quer, de uma maneira ou de outra, dizer ou responder o que é o ser humano, o mundo, e o ser humano no mundo. A ciência, por si só, não tem como responder ou acenar respostas definitivas nessa direção (GHEDIN \& FRANCO, 2006, p. 15). 
Nesta mesma direção teórica, encontramos Nóvoa (2001) ao defender que as "novas" Ciências da Educação precisam romper com a investigação baseada na racionalidade técnica, ou mesmo em procedimentos exclusivistas que não permitam a análise do fenômeno educativo por diferentes vieses, enfrentando a dicotomia entre o campo da ciência e o terreno social das práticas, nem tampouco, abandonando-se o rigor da pesquisa:

As "novas" Ciências da Educação devem integrar as diversas racionalidades, não caindo no totalitarismo da exclusão, mas antes na afirmação da diversidade e do pluralismo. As opções científicas e metodológicas devem pautar-se por critérios de coerência e pertinência em relação ao objecto em estudo, e não por uma qualquer decisão apriorística sobre a validade das teorias ou das práticas de investigação (NÓVOA, 2001, p.83).

A partir deste ponto de vista, julgamos que a triangulação dos dados, presente na abordagem multirreferencial, configura-se como o tratamento metodológico mais apropriado para os aspectos nesta pesquisa, uma vez que optamos pela análise dos elementos estruturais dos cursos, relatos dos sujeitos que atuam como gestores educacionais, e a articulação dos referenciais anteriores com a perspectiva conceitual de trabalho baseado no desenvolvimento profissional e institucional, que é colocado como suporte teórico desta pesquisa.

Deste modo, podemos afirmar que a adoção desta conduta para a pesquisa permite simultaneamente a combinação metodológica da análise dos dados para a investigação do objeto, colher dados de diferentes ângulos acerca do problema da pesquisa, para combiná-los, numa perspectiva contrastiva, relacionando estas diferentes categorias de elementos para revelar o que não foi possível de ser visto em trabalhos de investigação anteriores.

Compreendemos que este tratamento metodológico pode ser considerado profícuo para a leitura e compreensão das (co) relações e das contradições entre o campo da teoria e o campo da prática, no que se refere à formação dos gestores escolares no curso de Pedagogia. Assim, viabiliza a atribuição de significado específico para cada categoria de dados colhidos e, finalmente, para o que representam a partir de sua análise na totalidade. 
Em se tratando deste encaminhamento metodológico, baseando-se nas contribuições trazidas por Serrano (1998), alguns aspectos fundamentais da pesquisa qualitativa foram apontados, dentre os quais Gonzaga (2006) destaca que:

\begin{abstract}
Ao se reportar à pesquisa qualitativa, assumindo a condição de educadora, Serrano deixa bem claro que é fundamental o educador, ao abordar o problema, dar atenção especial à dimensão fundamentalmente prática, e não se ater exclusivamente aos fundamentos teóricos, pois seu objetivo, necessariamente, precisa se orientar para uma melhoria e transformação da realidade, uma vez que o indivíduo se forma como homem e como membro de uma coletividade (GONZAGA, 2006, p.88).
\end{abstract}

Portanto, nesta pesquisa fundamentada na perspectiva metodológica da multirreferencialidade, compactuando a idéia da pesquisadora, nos dedicaremos a construir uma análise da formação inicial dos gestores escolares, a partir de matrizes legais que orientam a matéria, e comparando-a com pressupostos teóricos que apresentam a concepção de gestão escolar e educacional que acreditamos ser salutar para o desenvolvimento institucional das escolas, e complementarmente comparar com a profissionalidade apresentada pelos gestores escolares em exercício para possivelmente darmos nosso aval favorável às matrizes curriculares que compõem o corpus desta pesquisa.

Finalmente, ao contrário do que se pode sugerir, ao optarmos por uma análise mais plural e diversa, não nos reportamos a uma fragilização do rigor científico, nem tampouco ao emprego de um conjunto desmedido de instrumento que sirvam para comprovar percepções pré-concebidas, mas corroboramos a importância da pesquisa considerar diferentes alternativas de análise do problema, a partir das evidências observáveis pela utilização de instrumentos diversos. 


\section{Dos procedimentos metodológicos}

Baseados na concepção qualitativa e na abordagem metodológica multirreferencial, que justificamos anteriormente, adotaremos um conjunto de procedimentos que, embora se valham de diferentes fontes de análise, nos permitirá a investigação mais próxima da totalidade do problema, por assim descrevê-los:

- Revisão histórica do curso de Pedagogia - inicialmente, resgataremos a história do curso de Pedagogia, a partir dos principais dispositivos legais reguladores do curso (Lei de Diretrizes e Bases e normas federais complementares) com o objetivo de se identificar o movimento organizativo do curso durante o processo de mudanças sociais e da política educacional do Brasil, apontando os aspectos relacionais entre si, sobretudo, a partir do século passado;

- Análise de matrizes curriculares dos cursos de Pedagogia foi selecionada uma amostragem de matrizes de 130 cursos, de instituições públicas (33) e privadas (97), que tiveram seus componentes como objeto de análise. Destacamos que a seleção das matrizes foi circunstanciada pelos seguintes critérios:

- diversidade na natureza institucional dos cursos (público e privado);

- cursos organizados com base na Resolução CNE CP 01/06, diversidade regional nacional dos cursos selecionados e da modalidade presencial;

- informação disponível acerca das disciplinas e cargas horárias constituintes dos cursos; 
- preferencialmente, cursos com informações sobre suas atividades complementares, e a indicação de estágio supervisionado.

Por se tratar de um estudo qualitativo, a opção foi a de abordar instituições de diferentes naturezas institucionais para a diversificação das propostas, assim, como demonstração de certa tendência nacional dos cursos. A partir disso, realizou-se a deteç̧ão e o estudo da disposição curricular adotada pelos cursos, especificamente, como se dedicam à formação dos gestores escolares, com o propósito de compreender o "espaço curricular" destinado a esta formação no decorrer do curso e a compatibilidade destes espaços destinados ao que propõem os dispositivos legais e os propósitos teóricos que elegemos como basilares para a formação dos gestores;

- Análise de questionários dos gestores escolares sobre a organização e a realização de seu trabalho - a concepção de trabalho baseada na perspectiva do desenvolvimento profissional e institucional é destacada como suporte teórico desta pesquisa, ao considerar-se a suposta virtuosidade que reconhecemos nesta proposta de atuação. Contudo, supomos que a atuação relacionase à formação dos professores, assim, optamos por colher depoimentos de 42 gestores (12 supervisores, 14 diretores e 16 professores coordenadores) sobre os desafios que enfrentam no seu cotidiano e os saberes que se valem para tal. Todos os participantes são profissionais da escola pública estadual de São Paulo (ensino fundamental e médio), o que situará os dados num campo específico de trabalho.

Pretende-se identificar os elementos presentes no curso de Pedagogia que se mostram como significativos para a profissionalidade dos gestores escolares na perspectiva de trabalho que apresentamos anteriormente. Para tanto, serão organizadas sete questões semi-estruturadas relacionadas à 
formação inicial dos gestores escolares, à forma pela qual organizam o seu trabalho, e os desafios que encontram do desenvolvimento de sua profissionalidade.

- Triangulação dos dados: análise com base na multirreferencialidade de dados e instrumentos, fundamentada na combinação dos dados apurados na pesquisa, de modo a referilos ao mesmo objeto da pesquisa, ou seja, tendo como referência a relação entre o movimento histórico do curso de Pedagogia, a organização curricular para a formação dos gestores e a relação destas propostas com o contexto de atuação profissional.

\section{Dos eixos da pesquisa}

Esta pesquisa será desenvolvida com base na concepção de educação e de Pedagogia como ciência, anteriormente apresentadas, e a partir do tratamento metodológico constituído pelos procedimentos anteriormente discutidos, quando foram trazidas a justificativa e o objetivos da mesma, e destacando como eixos de discussão o que segue:

Capítulo I. Apresentará um panorama histórico do curso de Pedagogia no Brasil, com ênfase nos fatos que ocorreram a partir do século $X X$, destacando-se os movimentos e propostas de formação, principalmente do ponto de vista dos referenciais legais, para os gestores escolares, até muito recentemente chamados de especialistas em educação, possibilitando a compreensão da historicidade do curso e da formação inicial universitária dos gestores escolares, também designados como especialistas em educação.

Capítulo II. Trará como foco a discussão sobre o conceito de gestão que orienta a presente pesquisa, assim como as controvérsias entre o conceito de gestores escolares e especialistas em educação, e a atuação numa 
perspectiva de totalidade do trabalho pedagógico, considerando os elementos que são trazidos no curso de Pedagogia para a formação destes profissionais e a relação com sua profissionalidade nas escola pública, que elegemos como campo de trabalho priorizado nesta pesquisa;

Capítulo III. Será priorizada a análise de quais elementos presentes nos cursos de Pedagogia contribuem para a formação de profissionais que atuam nas escolas públicas numa perspectiva conceitual de desenvolvimento profissional e institucional, principalmente, considerando-se os desafios que os gestores encontram no cotidiano de seu trabalho. Ainda neste capítulo, ter-se-á como finalidade discutir a pertinência da formação anunciada nos curso de Pedagogia, a partir dos seus elementos organizativos com as propostas anunciadas pelos dispositivos legais e pelas necessidades apresentadas pelos gestores educacionais;

Considerações Finais. Propõe-se a análise integrada dos dados obtidos pelas fontes investigadas e que devem evidenciar as considerações acerca do problema central da pesquisa, tendo em foco "o lugar" da formação dos gestores escolares nos cursos de Pedagogia, principalmente, sob a perspectiva do desenvolvimento profissional e institucional das escolas. Nesta etapa, organizaremos as considerações finais em dois grandes blocos: o que encontramos a ser destacado na pesquisa e as proposições que defendemos para o estado atual do trabalho, como forma de retomar o atendimento aos objetivos iniciais propostos na pesquisa, além dos principais conhecimentos que foram produzidos durante a mesma.

Conclusão. Apresentação sistematizada das conclusões da pesquisa, apontando, mais objetivamente, o que já foi feito, o que está sendo feito, e o que ainda temos a fazer, no que se refere à formação superior dos gestores escolares, com vistas à sua profissionalidade e a melhoria do trabalho na escola pública. 


\section{CAPÍTULO I}

\section{Percurso histórico e legal da formação dos gestores escolares}

A proposta deste primeiro capítulo é a de situar o movimento do curso de Pedagogia no Brasil, principalmente nas últimas décadas do século XX, e primeira do XXI, e nele a formação dos pedagogos, que além da docência, serão responsáveis pelas atividades de planejamento, administração, inspeção, coordenação, orientação e supervisão educacional.

Realizaremos, primeiramente, o resgate histórico legal do que foi proposto para os "técnicos de educação", forjados em uma perspectiva pedagógica e ideológica que se baseava na "especialidade do trabalho", e complementarmente como esta proposta perde campo dentro do próprio meio da educação, implicando na constituição de profissionais que exigiriam outro tipo de formação, em virtude das necessidades dos sistemas educacionais.

Todavia, ao realizarmos este percurso histórico de construção da formação dos profissionais do magistério que se dedicariam às atividades de gestão, podemos rastrear as condições que coincidem entre a indefinição do curso de Pedagogia no Brasil, a indefinição da profissionalidade destes profissionais e as características presentes na sua profissionalidade.

Apresentaremos alguns dados sobre as características dos cursos de Pedagogia que serão tomados como corpus deste trabalho, indicando a formatação que passa a ter a formação dos profissionais do magistério nos cursos baseados na Resolução CNE CP 01/06, por ocasião das Diretrizes Curriculares para o Curso de Pedagogia.

Esta trajetória histórica nos permitirá aprofundar a análise acerca da abordagem, concepção e tratamento curricular destes cursos para a formação dos profissionais, diante das necessidades que lhes são apresentadas pelos sistemas de ensino e as escolas onde atuam.

Portanto, ao mesmo tempo em que nos valeremos basicamente do instrumento legal para esta etapa do trabalho, traremos algumas análises de dados referentes aos currículos, para posteriormente identificar sua possível 
contribuição para uma proposta de formação que se paute na possibilidade do desenvolvimento profissional docente e institucional.

\subsection{A configuração da formação dos especialistas em educação nos últimos anos: referências legais.}

Propomo-nos, no início desta pesquisa, a discutir a formação dos especialistas em educação, mais propriamente em gestão escolar, no curso de Pedagogia. Assim, para a concretização desta tarefa, obrigamo-nos a recorrer à história dos referidos cursos no Brasil, para assim resgatarmos os elementos que caracterizam a construção da identidade destes profissionais nas diferentes propostas do curso, sobretudo, a partir da década de 1930.

Por este levantamento crítico da história da Pedagogia e da formação dos pedagogos, com destaque aos especialistas em educação que atuam em atividades de gestão, desejamos apontar a historicidade do processo de constituição destes ofícios.

Se em princípio reconhecemos alguns elementos - a serem tratados adiante - que indicam certa indefinição no curso de Pedagogia, tais como: período de integralização, ofícios profissionais contemplados no curso, a organização curricular, a proposta de carga horária, a distribuição temporal do curso, a matriz de disciplinas, concluímos que historicamente isso tem sido uma marca deste curso.

A situação de ambigüidade a que nos referimos, provavelmente remonta à condição do exercício dos profissionais do magistério que, no caso do Brasil, tem início com a predominância de educadores marcantemente religiosos e posteriormente, já no século XVIII e XIX, a presença de educadores laicos, que, no entanto, submeter-se-iam ao controle do Estado no estabelecimento de suas obrigações profissionais e, consequentemente, no controle sobre a profissão docente e dos fazeres dos pedagogos em campos diversos da escola e educação. 
No ano de 1939, foi criado o curso de Pedagogia vinculado à Faculdade Nacional de Filosofia que, na Universidade do Brasil ${ }^{13}$, teria como objetivo formar os técnicos em educação, concebido como um bacharelado e se aproximava intensamente dos demais bacharelados que derivavam das áreas de Filosofia, Letras ou Ciências oferecidos por esta universidade no Rio de Janeiro.

Em pesquisas realizadas anteriormente por Marques (2003), observouse que esta formação bacharelesca, prevista pelo Decreto 1190/39, diferenciava a formação dos licenciados, basicamente pela inclusão do curso de didática à sua formação inicial ${ }^{14}$, o que o tornaria licenciado, e sem o qual configurar-se-ia como um "técnico de educação":

O curso de Pedagogia, desde sua criação em 1939, tem trajetória marcada pela indefinição. Estruturava-se, inicialmente, em um Bacharelado de três anos, a que se superpunha para a Licenciatura, um ano de Didática (esquema $3+1$ ). O bacharel em Pedagogia seria o indivíduo habilitado a exercer as funções de "técnico da educação", funções indefinidas em si mesmas e nas relações com os Bacharelados e Licenciaturas (MARQUES, 2003, p.123).

$\mathrm{Na}$ mesma perspectiva de demonstração das fragilidades, Saviani (2008) também apresentara crítica a este modelo, sobretudo por entender que a matriz imposta durante as décadas de 1930 e 1940, para o curso de Pedagogia, era fechada, o que implicaria em defender a proposta de "técnico em educação", porém não esclarecia quais seriam as funções a serem

\footnotetext{
13 No ano de 1939, na Universidade do Brasil, predominava a organização institucional departamental, que perduraria por décadas e se tornaria o modelo estrutural ainda vigente das instituições de Ensino Superior. Neste caso, ocorreu a criação não exatamente de departamentos, mas de quatro seções acadêmicas que contemplavam as áreas da Filosofia, Ciências, Letras e Pedagogia, predominantemente na forma de bacharelados, principalmente por haver apenas na seção de Pedagogia o curso de Didática, que tornaria os demais bacharéis, licenciados.

${ }^{14}$ Em 1931, cria-se na USP, uma forma de especialização do Curso Normal, que à época formava dos docentes para a atuação nos jardins da infância e escolas primárias, destacando, portanto, disciplinas como a Didática, Filosofia e História da Educação. Já em 1934 é criado o Departamento de Educação, junto à Faculdade de Filosofia, Ciências e Letras da USP, organismo que posteriormente daria origem ao curso de Pedagogia no Brasil, e a Faculdade de Educação.
} 
desempenhadas por estes técnicos nem tampouco conferia-lhes o direito à docência de forma regular. Assim, o pesquisador expõe que,

Com efeito, supondo que o perfil profissional do pedagogo já estaria definido, concebeu um currículo que formaria o bacharel em Pedagogia entendido como o técnico em educação que, ao cursar didática geral e especial, se licenciaria como professor. Mas, quais seriam as funções técnicas próprias do pedagogo? Em que medida o currículo proposto para o Bacharelado daria conta de formar esse técnico? E o licenciado em Pedagogia poderia lecionar que matérias? Por suposto, as matérias constantes de seu currículo de Bacharelado, como ocorria com os cursos das seções de filosofia, ciência e letras (SAVIANI, 2008, p.41).

Através de uma reflexão sobre o processo histórico do referido curso, constatamos certas deformidades causadas à Pedagogia, ora pela sua proposta curricular hermética, que priorizaria disciplinas genéricas do campo da educação, ora pela carência de regulamentação para a própria formação dos estudantes que pretensamente dispunha-se a formar.

Mais precisamente no final da década de 1930 e início de 1940, algo proposto e centralizado pelo então Ministério dos Negócios da Educação e Saúde Pública, que centralizava as decisões do campo educacional sob a égide dos princípios da Escola Nova no período getulista.

Em resposta a esta centralidade e controle impostos pelo Estado, intelectuais como Anísio Teixeira e Fernando de Azevedo expressaram sua indignação com o encaminhamento nacional dado à educação, sistematizado no que se denominara Manifesto dos Pioneiros da Educação Nova de 1932.

Este documento impulsionaria a discussão sob a profissionalização dos docentes e também dos demais técnicos que atuariam como especialistas em educação. O próprio trecho do documento - apresentado abaixo - destaca a necessidade de mudança de rumos na formação dos professores, ao se reportar a uma mudança voltada ao campo das idéias do pensamento pedagógico, e que também implicaria na formulação de outros dispositivos legais que regulariam a formação do pedagogo:

Os professores de ensino primário e secundário, assim formados, em escolas ou cursos universitários, sobre a base de uma educação geral comum, dada em estabelecimentos de educação secundária, não fariam senão um só corpo com os do ensino superior, preparando a fusão sincera e cordial de todas as 
forças vivas do magistério. Entre os diversos graus do ensino, que guardariam a sua função específica, se estabeleceriam contatos estreitos que permitiriam as passagens de um ao outro nos momentos precisos, descobrindo a superioridade em gérmen, pondo-as em destaque e assegurando, de um ponto a outro dos estudos, a unidade do espírito sobre a base da unidade de formação dos professores (trecho do Manifesto dos Pioneiros da Educação de 1932).

Todavia, o surgimento de um pensamento combativo por parte dos Pioneiros da Educação, na tentativa de indicar novos rumos para a formação dos professores, pedagogos e para a educação, contrastava com as diretrizes da política educacional, que emanavam do Estado centralizador, destacandose a política implantada pelos então ministros Francisco Campos e Gustavo Capanema, doutrinas estas que iriam perdurar durante toda a década de 1940 e até meados de $1950^{15}$, marcadas paradoxalmente pela criação de órgãos voltados para o fomento da educação, mas em função de uma missão daquele Estado.

A edição da Lei de Diretrizes e Bases da Educação 4024, de 1961, intensificava a discussão acerca da indefinição sobre "onde se formariam os profissionais da educação e da docência". Entretanto, o próprio texto legal não dispunha de esclarecimento ou indicação suficiente para avanços significativos na organização dos cursos, e ainda reafirmava o encaminhamento de formação fracionada existente até aquele momento, a saber:

Art. 62. A formação do orientador de educação será feita em cursos especiais que atendam às condições do grau do tipo de ensino e do meio social a que se destinam.

Art. 63. Nas faculdades de filosofia será criado, para a formação de orientadores de educação do ensino médio, curso especial a que terão acesso os licenciados em pedagogia, filosofia, psicologia ou ciências sociais, bem como os diplomados em Educação Física pelas Escolas Superiores de Educação Física e os inspetores federais de ensino, todos com estágio mínimo de três anos no magistério.

Art. 64. Os orientadores de educação do ensino primário serão formados nos institutos de educação em curso especial a que terão acesso os diplomados

\footnotetext{
${ }^{15}$ Entre o final da década de 1930 e meados da década de 1950 foram criados institutos e comissões que tiveram forte impacto na reunião de dados educacionais, e no início da sistematização de estudos sobre os sistemas de educação, dentre elas: INEP - Instituto Nacional de Estudos Pedagógicos - Anísio Teixeira (1938); CAPES - Coordenação de Aperfeiçoamento de Pessoal de Nível Superior (1951); CBPE - Centro Brasileiro de Pesquisas Educacionais (1955).
} 
em escolas normais de grau colegial e em institutos de educação, com estágio mínimo de três anos no magistério primário.

Art. 65. O inspetor de ensino, escolhido por concurso público de títulos e provas vetado deve possuir conhecimentos técnicos e pedagógicos demonstrados de preferência no exercício de funções de magistério de auxiliar de administração escolar ou na direção de estabelecimento de ensino (LDB 4024/61).

Em 1962, período pré-golpe militar, por meio do Parecer CFE 251/62, apresentou-se uma nova proposta para o curso de Pedagogia. Neste caso, definia-se o período de quatro anos para o curso; assim como a desnecessidade do esquema " $3+1$ ", já que agora os pedagogos poderiam tornar-se licenciados, cursando disciplinas para a docência concomitantemente às demais, que caracterizavam a condição de bacharel em Pedagogia.

Novamente, este parecer tecia críticas à ausência de identidade do curso de Pedagogia, que não definiria exatamente como formar seus profissionais. Contudo, a crítica à carência de identidade do curso permanecia existente com as proposições deste parecer, principalmente por não identificar a relação que a formação do pedagogo deveria estabelecer com os ofícios que exigiam saberes pedagógicos, afastando-se de uma proposta curricular de integralidade, e revalidando a concepção de complementação, como fez referência, o seqüencial Parecer CFE 252/69 ${ }^{16}$ :

O setor de Educação ajusta-se de fato a estas premissas. A profissão que the corresponde é uma só e, por natureza, não só admite como exige "modalidades" "diferentes" de capacidade, a partir de uma base comum. Não há, em conseqüência, por que instituir mais de um curso, porquanto, mesmo nas habilitações que as universidades e os estabelecimentos isolados venham a acrescentar, a maior parte das disciplinas se repetirá fatalmente em todas, com pouca ou nenhuma adaptação. A nosso ver, somente quando se ultrapasse o terreno propriamente educacional, em alguns casos o curso assumirá estrutura e tomará denominação diferente (Parecer CFE 252/69).

Na visão de Silva (2006) e Marques (2003), a década de 1960 permaneceu contraditória no que se referia ao currículo do curso, sobretudo no aspecto da formação inicial do pedagogo, uma vez que estava previsto

\footnotetext{
${ }^{16}$ Nos termos deste Parecer, poderia o pedagogo atuar como docente também nas disciplinas do então ensino secundário, além do Curso Normal e no Ensino Primário, sendo que a licença para atuação na Pré-Escola e nas funções destinadas a gerir a escola seria concedida cursando-se as habilitações do curso de Pedagogia.
} 
formarem-se inicialmente os profissionais da educação não docentes na Pedagogia, então como Bacharelado e, posteriormente, os docentes das matérias pedagógicas, numa espécie de complementação para a aquisição da condição de licenciados, germinando a concepção de profissionais genéricos que poderiam se tornar especialistas.

Mesmo com estas mudanças permanecia a idéia de que o curso de Pedagogia formaria técnicos e complementarmente docentes para as matérias pedagógicas oferecidas no Curso Normal para a formação dos professores primários. Permaneciam os princípios organizativos baseados numa perspectiva tecnocrática, como sugere Almeida (2008):

É, portanto, a partir da idéia da ideologia tecnocrática que a política educacional do governo militar vai ser orientada e fundamentada. Procurando o ajuste da política educacional à nova etapa de desenvolvimento econômico e do processo social, marcado pela política desenvolvimentista da ditadura e pela intensificação da internacionalização do capital, a educação, em si, passa a ser alçada à formação de "capital humano". Isto é, os princípios de racionalidade, eficiência e produtividade são transplantados da teoria econômica e passam a ser adaptados è educação (ALMEIDA, 2008, p.76).

Ainda, neste percurso conflituoso da identidade do curso, Brzezinski (1996) afirma que a década de 1960 caracterizou-se por processos que buscavam legislar sobre uma profissão que não tinha seu campo de atuação claramente definido, fosse este na área da docência ou das demais atividades não docentes do pedagogo.

Além desta indefinição sobre o campo de atuação dos pedagogos, pouco se avançou do ponto de vista dos currículos do curso, que embora deixassem de prever a exclusiva formação para Licenciatura a posteriori do Bacharelado, não aprofundou as discussões sobre a organização dos cursos de Pedagogia embora, a partir de 1962, passou-se a ter disciplinas mais específicas para a docência ${ }^{17}$, inclusive como nas demais Licenciaturas.

\footnotetext{
17 Destaque-se que a formação para a docência prevista no curso de Pedagogia, neste momento histórico, era destinada àqueles que atuariam no curso normal, que sucedendo a conclusão do curso ginasial era o lócus responsável pela formação dos então professores primários, dos grupos escolares, que eram os prédios escolares destinados apenas ao estudo dos alunos que cursavam as séries iniciais, e que perduraram até o início da década de 70 ,
} 
Este modelo formativo iria perdurar por praticamente toda a década de 1960, sofrendo alterações apenas com a instauração da Reforma Universitária $^{18}$ de 1968, que alijou as instituições universitárias de qualquer autonomia, e as submeteu a rigoroso controle, tanto administrativo e financeiro, como pedagógico e político.

A reforma universitária de 1968, promulgada pela lei 5540/68, instaurou novos parâmetros para o curso, o que se fez regulamentar pelo consagrado Parecer CFE 252/69, de autoria do conselheiro Valnir Chagas, estabelecendo mínimos de conteúdos, prazo e forma de organização para a formação dos pedagogos.

O referido parecer firmava que deveria concentrar-se no curso de Pedagogia a formação para os profissionais da área da educação, devendo, portanto, ser um único curso, havendo, no entanto, um núcleo básico e um núcleo seqüencial de capacitação específica para determinadas áreas de trabalho traduzidas como habilitações, citando essencialmente:

Artigo $1^{\circ} \mathrm{A}$ formação dos professores para o ensino normal e de especialistas para as atividades de orientação, administração, supervisão e inspeção no âmbito de escolas e sistemas escolares, será feito no curso de graduação em Pedagogia, de que resultará o grau de licenciado com modalidades diversas de habilitação.

Artigo $2^{\circ} \mathrm{O}$ currículo mínimo do curso de Pedagogia compreenderá uma parte comum a todas as modalidades de habilitação, e outra diversificada em função das habilitações específicas. (Parecer CFE 252/69).

com a edição da Lei 5692/71, instaurando o chamado $1^{\circ}$ grau, que inicialmente apresentava-se não como articulação de um projeto de formação ampliada para os alunos, mas como uma "escola juntada", no que diria respeito aos alunos, professores, currículos e prédios escolares.

${ }^{18}$ Como um dos instrumentos mais perversos socialmente, e eficazes politicamente para a implantação da ditadura e repressão no Brasil, a Reforma Universitária trouxe consigo o acordo MEC - USAID, que implantava o modelo de desenvolvimentismo econômico, reforçou as práticas de ensino profissionalizante com ênfase tecnicista, cerceou a presença de conteúdos provocativamente críticos nos currículos dos cursos, promoveu a expansão acelerada da privatização do ensino superior, e aprofundou o processo de desprofissionalização do magistério implantando mecanismos altamente burocráticos de controle. Por estes, dentre outros pontos, podemos deduzir a estreita relação que a política educacional imposta pela Reforma Universitária estabeleceu com o pensamento sobre gestão da educação, implicando, inclusive na fragmentação do pensamento e do trabalho daqueles que seriam responsáveis pela organização da escola, demonstrando como exemplo, as habilitações na Pedagogia. 
É neste dispositivo legal que são legitimadas as habilitações do curso de Pedagogia, demonstrando o alto grau de compartimentalização e fragmentação acerca da formação inicial do pedagogo e de como se compreendia seu modo de atuar, proposta esta mantida até a década de 1990:

Segundo o plano proposto, o curso terá uma parte comum e outra diversificada. A parte comum será praticamente a mesma do Par. 251/62, incluindo aquelas cinco áreas cujo estudo "é realmente a base de qualquer modalidade de formação pedagógica, podendo, além disto, constituir objeto de habilitação especifica"(...). A parte diversificada compreende, basicamente, aquelas áreas desde logo mencionadas no art. 30 da Lei 5 540/68, excetuando apenas o Planejamento, que será desenvolvido em nível de Mestrado. Para o magistério dos cursos normais e as atividades de orientação, administração, supervisão e inspeção, previram-se cinco habilitações que se desdobram em oito ${ }^{19} \mathrm{com}$ a apresentação das três últimas também em curta duração, visando a escola de primeiro grau (Parecer CFE 252/69).

O mesmo parecer previa que as habilitações voltadas para as escolas de primeiro e segundo graus deviam ter no mínimo de 2200 horas, enquanto aquelas destinadas apenas às escolas de primeiro grau reconhecer-se-ia os cursos de 1100 horas, considerados como de curta duração, além do núcleo básico.

Esta possibilidade, prevista pelos artigos $5^{\circ}$ ao $7^{\circ}$ da Resolução CFE 2/69, regulamentada pelo citado Parecer CFE 252/69, estabeleceu que as habilitações deveriam ser baseadas fundamentalmente em disciplinas da área de aprofundamento, que os estágios deveriam contemplar ao menos cinco por cento da carga horária dos cursos, não se definindo carga horária mínima de integralização; além de que os egressos poderiam optar por duas habilitações, podendo à frente voltar a cursar as demais habilitações oferecidas pelo curso.

Esta maneira de organizar segmentadamente a formação dos pedagogos fora o marco da formação que lhes era destinada como

\footnotetext{
${ }^{19}$ As tais habilitações do curso de Pedagogia se inspiravam concepção de desenvolvimento e organização do trabalho advindas dos modelos taylorista e fordista, sendo as mesmas: magistério para as disciplinas do curso normal, orientação educacional, administração escolar, supervisão escolar, e inspeção escolar, sendo que as três últimas ainda podiam ser realizadas em cursos que habilitavam apenas para a atuação no $1^{\circ}$ grau, tornando-se oito possibilidades complementares.
} 
"especialistas", nas habilitações para administração escolar, orientação educacional, inspeção escolar e supervisão educacional, como conseqüência os sistemas de ensino foram criando espaços para esses "especialistas" ${ }^{20}$, no próprio sistema e nas escolas.

Muito pontualmente, Maciel e Neto (2004) afirmam que um dos efeitos da reforma universitária fora o de aprofundar o retalhamento do curso de Pedagogia e enfatizar a ruptura entre os que seriam docentes e os que eventualmente atuariam como técnicos e especialistas:

Na segunda fase (da Reforma Universitária até a LDB $n^{\circ}$ 9.394/96) o curso passa a ser regulamentado pelo Parecer $n^{\circ} 252$ (Brasil, 1969) e pela Resolução $n^{\circ} 2$ (Brasil, 1969). Eram instituídas as habilitações profissionais, pelas quais os alunos optavam a partir de determinado momento do currículo, tornando-se "especialistas" em áreas diversas do trabalho escolar. Percebe-se assim, claramente, o "retalhamento" da realidade, inviabilizando a visão de conjunto da situação educacional e escolar e fazendo valer "a idéia de que o técnico em Educação tornava-se um profissional indispensável à realização da educação como fator de desenvolvimento" (Silva, 1999: 43). Estratégia bem coerente com o modelo político-econômico que o Brasil vivia então (MACIEL; NETO, 2004, p. 16).

Embora a tentativa, aparentemente, fosse a de superar o sentido generalista até então predominante no curso de Pedagogia, o que se firmou foi uma nova maneira de fragmentação, baseada na formação de docentes e de profissionais que atuariam especificamente em determinadas áreas, uma contrariedade à possível integralidade da formação, com o que também concorda Saviani:

O aspecto mais característico da referida regulamentação foi a introdução das habilitações visando a formar "especialistas" nas quatro modalidades indicadas (Orientação Educacional, Administração Escolar, Supervisão Escolar e Inspeção Escolar), além do professor para o ensino normal. Dir-se-ia que, por esse caminho, se pretendeu superar o caráter generalista do curso que levava à definição irônica do pedagogo como "especialista em generalidades" ou, jocosamente, como "especialistas em coisa nenhuma". Pelas habilitações procurou-se privilegiar a formação de técnicos com funções supostamente bem específicas no âmbito das escolas e sistemas de ensino que configurariam um mercado de trabalho também supostamente já bem construído, demandando,

\footnotetext{
${ }^{20} \mathrm{Na}$ realidade, tanto a formação como a atuação desses profissionais era baseada num ideário de especialismo racional e tecnicista, e não de especialistas em educação, como sujeitos que detinham conhecimentos aprofundados em determinados campos de trabalho na organização da escola.
} 
em consequência, os profissionais com a formação específica que seria suprida pelo curso de Pedagogia; daí a reestruturação desse curso exatamente para atender à referida demanda (SAVIANI, 2008, p.49-50).

Pelas constatações do autor, verifica-se que permanecia a ruptura no curso, inclusive por não haver clareza no campo de trabalho, principalmente, para os especialistas em educação, fato que se agravava ao indicar que a complexidade do curso seria devidamente tratada apenas com a inclusão de disciplinas como: princípios e métodos, estatística aplicada, legislação de ensino e medidas educacionais, desvelando uma concepção que prevaleceu reiterando a idéia de uma formação baseada na perspectiva da racionalidade técnica.

A década de 1970, em meio ao período ditatorial, iniciou-se com a edição da Lei de Diretrizes e Bases 5692/71, que delegou à pós-graduação a formação dos pedagogos especialistas em educação, contraditoriamente, mantendo os cursos de curta duração para o exercício da docência, o que fortaleceu a segmentação do curso, conforme constatamos pelo artigo 33 da própria lei, deixando de haver uma mudança substancial na forma de organização e funcionamento do curso, no sentido de garantir uma formação inicial mais articulada aos desafios do contexto da profissão:

Art. 33 A formação de administradores, planejadores, orientadores, inspetores, supervisores e demais especialistas de educação será feita em curso superior de graduação, com duração plena ou curta, ou de pós-graduação (Brasil, Lei 5.692/71).

Há ainda que se observar que a experiência docente foi tomada como requisito para a formação dos especialistas somente na década de 1970, com a edição do Parecer CFE 867/72, o que não deixou de ser uma aproximação do curso às necessidades emergentes do capitalismo no Brasil, acentuando uma forma de expropriação do saber científico e da intelectualidade que deveriam fazer parte da formação inicial do pedagogo, naquele momento do país. 
A concepção tecnicista que marcou, principalmente, as décadas de 1960 e 1970, confirmava o atendimento às demandas capitalistas ${ }^{21}$, aplicando sobre os docentes uma forma de orientação acerca de seu ofício como se estes estivessem relegados ao exercício da prática, desvalorizando a capacidade de participação política e ideológica dos professores na construção da sua profissionalidade e profissionalização.

A nomenclatura especialista estava vinculada diretamente a uma suposta condição hierárquica de realização do trabalho na escola, e de formação dos profissionais que, mesmo atuando na escola e sendo graduados, eram considerados como não tão competentes para as atividades de planejamento, coordenação ou administração na escola.

Aprofundou-se a concepção contraditória sobre o que seria ensinar e o que seria organizar os processos escolares e pedagógicos, como se fossem dissociados e hierárquicos, e não apenas distintos.

A mesma regulamentação perdurou até meados da década de 1970, mais precisamente 1975, quando das Indicações CFE 67/75, 68/75, 69, 70 e 71/76 que anunciaram novas orientações para a Lei 5692/71.

Como destacou Silva (2006), houve um desdobramento do que estava agregado ao curso de Pedagogia, de modo que o mesmo ficasse confortado em habilitações direcionadas aos candidatos a especialistas, priorizando conhecimentos sobre os diversos campos de atuação dos pedagogos, sobretudo na escola, de modo que esses fossem entendidos como saberes pedagógicos na profissionalidade destes sujeitos dissociados.

Esse cenário da década de 1970 ocasionou novamente a discussão sobre o sentido e o enfoque dado ao curso de Pedagogia, uma vez que os

\footnotetext{
${ }^{21}$ Este período também teve como característica o enriquecimento das instituições de ensino superior que faziam das habilitações da Pedagogia um prolongado processo de "vendas em carnês", parcelando uma suposta formação a ser estendida, investindo-se também na fragmentação dos sistemas de ensino e das escolas, sendo uma mostra do esfacelamento intelectual do curso, e de sua destinação economicista.
} 
dispositivos legais da época propunham claramente um novo deslocamento da formação de docentes e de especialistas.

Silva (2006) reitera que as contradições dos cursos em relação a quem seriam seus egressos permaneceriam, como numa situação de escalonamento de poder em relação às possíveis situações de formação que decorreriam da Pedagogia, pois segundo a mesma, o curso de Pedagogia voltou-se à formação dos especialistas em educação, representados pelas funções de orientador educacional, administrador escolar e supervisor escolar, sem contudo extinguir a habilitação para atuar na docência para o curso normal, o que seria o precedente para que também pudessem atuar nas séries iniciais do ensino primário, como uma demonstração da tese defendida pelo então Conselho Federal de Educação de que "quem pode o mais, pode o menos", reproduzindo a análise hierarquizada os ofícios do magistério.

Se considerarmos que a forma de se pensar e organizar o processo de profissionalização dos sujeitos é fator interveniente na maneira pela qual irão desenvolver suas atividades, ou identificar sua introdução no campo de trabalho, a década de 1970 mostrou-se como tempo de debate sobre o curso de Pedagogia, principalmente por ser um dos momentos dotados de responsabilidade sobre uma forte divisão do trabalho na escola, o que até então era concebido numa lógica de intensa fragmentação, como defende Brzezinski (1996): No final da década de 1970 , uma das questões que preocupavam os
educadores brasileiros envolvidos com a formação de profissionais da
educação era a da reformulação ou a extinção do Curso de Pedagogia que
mais uma vez estava ameaçado por críticas à sua identidade. Tais críticas
vieram à tona com divulgação, em 1976, da Indicação de Valnir Chagas, do
Conselho Federal de Eduçãa, CFE, a qual propunha a extinção do Curso de
Pedagogia e consequentemente da profissão de pedagogo (BRZEZINSKI,
1996, p. 76).

A fragmentação que se colocava, marcada pela estrutura organizativa do curso, refletia a dificuldade em encontrar a identidade do pedagogo, uma vez que expressava o afastamento entre a formação e a investigação sobre a sua profissionalidade, reduzindo o foco da formação praticamente à sala de aula, 
ou seja, mesmo com as muitas limitações das habilitações quais fossem elas, voltava-se à discussão para a docência.

As críticas destinadas ao que se dispunha o curso de Pedagogia trouxeram não apenas a fragilização do sentido profissional do que poderiam fazer os pedagogos, mas também reduziam a compreensão dos ofícios como uma forma de agir pontualmente em problemas educacionais mais complexos.

Esta realidade demonstrava que as contradições no campo pedagógico estavam relacionadas a alguns aspectos dentre os quais: a identidade das propostas de formação; a orientação ideológica acerca do saber pedagógico defendida pelos educadores; e, sobretudo, "o como" a profissionalidade dos pedagogos, em especial dos especialistas em educação, seria pensada e desenvolvida no âmbito do mundo do trabalho.

Defender as idéias relacionadas a outra organização pedagógica para o curso e outros processos de formação, implicava enfrentar os aspectos que citamos anteriormente, superando a dualidade de formação que se impunha.

No entendimento de Libâneo (2002), esta ruptura é resultado incontestável das indicações do Conselho Federal de Educação, elaboradas principalmente pelo conselheiro Valnir Chagas, que prescrevera possibilidades formativas baseadas num certo fracionamento do exercício das atividades do pedagogo.

Com esta compreensão, Valnir Chagas tornou-se um dos conselheiros de educação responsáveis pela elaboração de uma série de pareceres e indicações que apontaram para esta lógica organizativa, como também se pode verificar nas constatações de Brzezinski (1996) e mais atualmente nas de Vargas (2007):

As críticas à identidade do Curso de Pedagogia, se davam, devido ao caráter tecnicista da formação ofertada e da variedade de habilitações que o diploma abrangia, pois ele formava tanto o professor para o ensino normal, como o especialista para a gestão escolar. E após a recomendação de Valnir Chagas, passou a formar também o docente para as séries iniciais do antigo primeiro grau. No entanto, segundo o legislador, o que se pretendia era formar o gestor no professor, ou seja, um profissional que tivesse como base de sua formação a docência. Contudo, esse entendimento acabou por fragmentar ainda mais o curso, pois este ficaria quase que reduzido somente à prática em sala de aula. 
A indicação de Chagas contribui ainda mais para o empobrecimento teórico que tanto era questionado pelos educadores e deixou a identificação do pedagogo mais confusa e sem definição (VARGAS, 2007, p. 36).

De acordo com os estudos realizados, principalmente por Brzezinski (1996), foi constatado que é a partir da década de 1980, com a edição do parecer CFE $161 / 86^{22}$, que se intensifica o reencaminhamento e a discussão acerca do curso de Pedagogia e, conseqüentemente, da formação dos profissionais a que se dedicaria o curso, propondo-se que fosse dado valor a experiências de formação que também se relacionassem à docência, não definindo qual o lugar, nem a forma de tratar a gestão no curso. Neste sentido, Vargas (2007) afirma que:

Felizmente, também no Parecer CFE n 161/1986, intitulado "Reformulação dos cursos de Pedagogia", a Conselheira Eurides Brito da Silva, além de traçar um histórico do curso e das regulamentações feitas pelo Conselho, faz comentários sobre os projetos de reformulação apresentados para análise, sugerindo que devem ser estimuladas experiências de formação, como, por exemplo, as que dão ênfase à docência para as séries iniciais do ensino fundamental. As propostas curriculares com essa ênfase foram aceitas até 1995, quando, pela Lei $n^{\circ} 9.131$ foi instalado o Conselho Nacional de Educação (VARGAS, 2007, p. 37).

O antagonismo que caracterizavam o curso de Pedagogia, sobretudo no que se referiria à formação dos profissionais e, neste caso, especificamente dos especialistas em educação, caracterizaram o curso desde sua organização sistematizada no Brasil, em 1939, até a década de 1980, culminando posteriormente com a edição da Lei de Diretrizes e Bases 9394/96, que não dissolvera tais conflitos ideológicos.

Todo o movimento histórico pelo qual passou o curso de Pedagogia acentuou a ruptura entre a idéia de trabalho dos docentes e dos profissionais

\footnotetext{
${ }^{22}$ Este parecer, do então Conselho Federal de Educação, sob a redação da conselheira Eurides Brito da Silva, recebeu o título de "Reformulação do Curso de Pedagogia", pois embora não dissolvesse os dilemas acerca da identidade dos profissionais egressos do curso, nem tampouco as obrigações que a este curso caberia curricularmente, apontou-se para a aproximação da formação dos professores para as séries iniciais na Pedagogia, ficando a formação daqueles que atuariam na educação infantil nos cursos de habilitação específica para o Magistério, instalado da Lei 5692/71.
} 
que desenvolveriam atividades relativas aos processos de gestão do trabalho pedagógico, o que, ao invés de contribuir para a construção de uma identidade de trabalho em torno de saberes indispensáveis ao pedagogo na atuação educativa, provocou não apenas a fragmentação na carreira, mas a fragmentação de como seriam pensadas as diferentes atividades deste profissional na esfera nacional, regional ( nas unidades federativas) e local (nas escolas) .

A este respeito, Brzezinski (1996), fazendo referência ao processo histórico do curso, mais precisamente até o final da década de 1970, alerta que o destaque atribuído à proposta de habilitações ampliou a dicotomia entre o sentido colaborativo tanto de docentes como dos especialistas em educação, valorizando mecanismos de regulação da profissão por parte dos profissionais, que seria controlada à necessidade de cada sistema, sob inúmeros aspectos:

\begin{abstract}
A modalidade de formação do especialista imposta ao curso de Pedagogia pela lei conduziu fatalmente a uma visão desintegradora do trabalho pedagógico e acabou provocando no exercício profissional embates entre especialistas e professores, porque aqueles, mesmo sem possuir formação apropriada, desempenhavam função que Ihes conferia status na hierarquia escolar. Essa posição foi reforçada pela própria regulamentação da carreira do magistério que, por injunções coorporativas, concedeu aos especialistas da educação de diversas unidades da Federação uma remuneração mais elevada do que a do professor, pela mesma jornada de trabalho (BRZEZINSKI, 1996, p.77).
\end{abstract}

Mesmo com a participação ainda não tão expressiva das associações e dos educadores que se dedicavam à causa da Pedagogia até este período, no início dos anos 1980 foi realizada a I Conferência Brasileira de Educação (CBE), cujo um dos objetivos principais foi o de discutir o sentido do trabalho e a formação dos pedagogos.

Neste encontro, foi criado um comitê dedicado à reformulação dos cursos de Pedagogia e Licenciatura, que resultaria em 1984 na terceira conferência, num documento, propondo uma base comum para a constituição e identidade docente nos cursos de formação.

A partir de 1983, a Comissão Nacional para Formação dos Profissionais da Educação - CONARCFE, posteriormente ANFOPE - Associação Nacional 
para Formação para os Profissionais da Educação - aprofunda o debate, contrariando-se a extinção do curso de Pedagogia e portanto, reforçando a necessidade da construção da identidade intelectual do pedagogo e do seu trabalho, iniciativa esta que não resolveria o problema do curso, mas faz reacender a emergência de se colocar em debate nacional, acadêmico e científico a identidade profissional dos pedagogos e sua gênese educacional.

Pesquisas realizadas por Brzezinski (1996) constataram que durante o Terceiro Encontro Nacional da CONARCFE (1984), estabeleceu-se que esta base nacional comum seria orientada pela ênfase numa dimensão profissional, numa dimensão política e numa dimensão epistemológica, o que se colocava como uma iniciativa no sentido de se perseguir uma formação que aliasse o campo da pesquisa, o campo da atuação e os diferentes saberes pedagógicos.

Esta tendência ganha repercussão, principalmente a partir de 1990, quando o supracitado comitê tornou-se ANFOPE, defendendo a docência como base da identidade profissional do pedagogo, gerando outras controvérsias, dentre as quais: é a docência a base da Pedagogia, ou o conhecimento pedagógico (e portanto ciência) é a força motriz da docência?

Trazendo como exemplo desta dicotomia, a defesa que o curso de Pedagogia deveria destinar-se a formação dos docentes que atuariam nas séries iniciais do ensino fundamental, sem contudo, prescindir da aquisição de saberes para as demais atividades pedagógicas, era a posição de Iria Brzezinski, Ildeu Coelho, Helena de Freitas, Leda Schreibe e, Márcia Ângela Aguiar.

Outros educadores, porém, como José Carlos Libâneo e Selma Garrido Pimenta, defendiam que destinar o curso a esta prioridade reduziria o significado da Pedagogia, como campo da ciência, reduzindo-o à formação docente, e opcionalmente a conferência dos títulos de especialistas em educação nas diferentes áreas de coordenação, direção, supervisão, administração, como se fossem meros técnicos, carentes da compreensão institucional da escola. 
Este movimento, iniciado na década de 1980 em torno da discussão do curso de Pedagogia e da identidade profissional de seus egressos, ficou conhecido como Movimento dos Educadores pela Formação do Pedagogo, que foi originado no I Seminário de Educação Brasileira de 1978, na Faculdade de Educação da UNICAMP.

Tal processo almejava enfrentar a política impositiva acerca das decisões do curso, buscando certa democratização pedagógica na construção das propostas de reformulação do curso, que doravante seriam propostas, articulando bases teóricas, práticas e epistemológicas, como Almeida (2008) sugeriu a partir de seus estudos, valendo-se do próprio texto da comissão:

Diante desse quadro de perspectivas, o objetivo de uma formação do pedagogo com caráter cientifico, acadêmico, político, técnico, didáticopedagógico, foi sendo redimensionado, posto que as mudanças pensadas no interior do movimento deveriam abranger todo o "sistema de formação de professores". Ao considerar que a formação pedagógica do professor mantém sua base teórico-epistemológica no campo educacional e a base da identidade do profissional da educação encontra-se na docência: todos são professores (Comissão Nacional para a Formação dos Profissionais da Educação, 1983, p. $5)$.

Abordaremos adiante a formação do pedagogo e o curso de Pedagogia mais contemporaneamente, entretanto, a partir da década de 1990 com a publicação da Lei Federal 9394/96, com as manifestações das associações e comissões de pesquisadores permaneceram demonstrando as contradições que marcavam o curso de Pedagogia.

A exemplo deste efeito contraditório, Almeida (2008) destacou o impacto provocado pela ANFOPE ao defender a docência como base identitária do pedagogo, o que se firmou como um dos marcos para uma nova etapa intelectual e histórica da organização do curso:

No documento final do XI Encontro a ANFOPE fica explícito que a Pedagogia é um curso de graduação plena, superando a divisão entre o Bacharelado e Licenciatura presente nas demais áreas de formação de professores. Indica que "caso a especificidade resvale para a formação exclusiva do cientista da educação ou do especialista, "a crise" se aprofundará com a retirada da prática de formação de professores, a retomada das habilitações e a fragmentação na formação dos especialistas". Nesse Encontro há o reconhecimento da necessidade de estabelecer uma interlocução com os Fóruns das Licenciaturas, ou seja, uma interlocução com novos parceiros criados nas IES, com o objetivo de melhor integrar as diferentes áreas e unidades das 
instituições responsáveis pela formação dos profissionais da educação e superar os antagonismos presentes nas estruturas curriculares (Bacharelado $\mathrm{x}$ Licenciatura; conteúdos específicos $\mathrm{x}$ conteúdos pedagógicos; Pedagogia $\mathrm{x}$ Licenciaturas) (Documento Final. X Encontro. ANFOPE, 2000). No XII Encontro da Educação, realizado em agosto de 2004, a trajetória dos debates emergiram posto as normas complementares da LDBN/96 que passa a defender o Curso de Pedagogia como formador acadêmico-científico da educação (ALMEIDA, 2008, p.97).

As impressões apontadas por esta pesquisadora reafirmam a existência de outras concepções sobre o curso, como é o caso do posicionamento do FORUMDIR (Fórum de Diretores de Faculdades Centros de Educação de Universidades Públicas) que, em 2004, na publicação de seu documento de orientação, declarava que o curso de Pedagogia deveria propor-se a uma formação integrada, com vistas à superação da proposta de habilitações que, até então, servia principalmente à gestão educacional.

De acordo com o FORUMDIR, o curso se destinaria à formação de docentes para a educação infantil e séries iniciais do ensino fundamental, a docência das disciplinas pedagógicas e para a atuação nas atividades de gestão em educação, seja esta em processos escolares ou não escolares, e ainda, garantindo a produção e a difusão dos conhecimentos e saberes pedagógicos, conforme destacamos do próprio texto publicado por este colegiado:

O Fórum de Diretores das Faculdades/Centros de Educação das Universidades Públicas Brasileiras (FORUMDIR) também participa da discussão e elaboração das diretrizes para o curso de Pedagogia. Dessa forma, divulga que: o curso de graduação em Pedagogia oferece ao pedagogo uma formação integrada para exercer a docência nas Séries Iniciais do Ensino Fundamental, na Educação Infantil e nas disciplinas pedagógicas dos cursos de formação de professores e para atuar na gestão dos processos educativos escolares e não-escolares, bem como na produção e difusão do conhecimento do campo educacional. Através desse documento, o FORUMDIR propõe uma formação integrada, relacionando a unidade entre Licenciatura e Bacharelado com vistas a superação das habilitações fragmentadas por meio de uma concepção de gestão educacional entendida "como a organização do trabalho pedagógico especialmente no que se refere ao planejamento, à coordenação, ao acompanhamento e à avaliação dos processos educativos escolares e dos sistemas de ensino e o estudo e a participação na formulação de políticas públicas na área de educação" (FORUMDIR, 2004). 
Diante do que expusemos, julgamos que a identidade do curso de Pedagogia sofrera o impacto de todas as situações de crise e de mudança da educação brasileira, ora por carecer de regulamentação clara que lhe conferisse condições para contribuir na transformação da educação, sendo quase que meramente objeto de reorganização, ora pelo fato de sofrer o impacto das demandas que eram impostas às escolas que reivindicariam outros postos de trabalho, sem necessariamente articularem-se pelo viés pedagógico de um projeto de trabalho colaborativo.

No âmbito das atividades de formação dos que eram chamados de especialistas de educação, e posteriormente gestores escolares/educação, como tratarmos esta necessidade de encontro de uma identidade profissional marcou a existência de orientadores e inspetores educacionais, diretores de escola, coordenadores pedagógicos e, posteriormente, supervisores pedagógicos, escolares e de ensino, numa perspectiva essencialmente de sobreposição, que precisaria ser superada para que se alcance algumas intersecções em sua profissionalidade.

Ao investigarmos o processo de formação destes profissionais, e como desenvolvem seu trabalho no âmbito do contexto escolar, pretendemos levantar o conjunto de competências ${ }^{23}$ que orientam e que implicam em sua profissionalidade de modo a contribuir para o desenvolvimento institucional das escolas, que organizam seu trabalho e definem suas prioridades tendo seu projeto pedagógico como foco, aspecto que na proposta de formação de "técnicos em educação" ficaria relegado ao plano das atividades específicas.

\footnotetext{
23 A literatura educacional tem apresentado recorrentemente o emprego do termo "competência", tanto nas propostas com ênfase mais progressista e crítica, como naquelas envolvidas por idéias mais racionalistas e liberais. Em nosso caso, entendemos competência como a orquestração de capacidades e habilidades dos sujeitos, em favor da mudança, produção de conhecimento, melhoria do que se faz, mediando-se as ações pela responsabilidade ética e pelo compromisso político, portanto não se trata da apropriação de mecanismos lineares para se operar com eficiência.
} 


\subsection{0 curso de Pedagogia pós Lei 9394/96: impasses e avanços na formação dos especialistas de educação}

Até este momento, trouxemos a gênese do curso de Pedagogia no Brasil desde 1939. Mais especificamente, passamos pelos impactos da Reforma Universitária de 1968, que motivou a edição do parecer CFE 252/69, qual marcou a proposta de formação, principalmente dos especialistas em educação no curso.

Trataremos daqui em diante, com destaque, os debates que ocorreram a partir da década de 1980, com o impulso do Movimento dos Educadores, culminando na publicação da Lei 9394/96, que regulamentou a formação dos docentes e, no caso desta pesquisa, dos profissionais do magistério dedicados aos ofícios de gestão escolar.

A década de 1980 exigia um profundo debate sobre o sentido dos cursos de Pedagogia, principalmente pela indefinição do caminho formativo que seria adotado, ainda marcado por inúmeros dilemas decorrentes da condição de conflito e ambiguidade de concepções, que até então marcava o curso de Pedagogia, desde a sua origem no país, tanto com relação à organização curricular, aos profissionais egressos, ao tempo destinado ao curso ou ao papel formativo para os bacharéis, assim como a aproximação ou distanciamento da formação do pedagogo com a escola, como espaço educativo e privilegiado para a atuação do mesmo.

Vale iniciarmos a reflexão pelo fato de que o aumento da pressão para novas diretrizes curriculares e educacionais do Brasil emerge da Conferência Mundial de Educação para todos de $1990^{24}$, em que apontara a educação

\footnotetext{
${ }^{24}$ Conferência realizada em 1990, em Jomtien, da qual originou a "Declaração Mundial sobre educação para todos", que discutiu o descompasso entre o crescimento econômico mundial a partir da década de 1980, e os significativos cortes nos setores de investimento social, o que provocou a intensa degradação da educação. Destacou-se a importância do atendimento das Necessidades Educacionais Básicas de Aprendizagem, para uma educação básica fundamental à condição de melhoria qualitativa da educação, e a promoção da dignidade humana, o que implicaria numa mudança no padrão de reformas até então implantadas, e nos modelos de gestão da educação, não apenas como conjunto de procedimentos de racionalização.
} 
como um tesouro a ser descoberto pelas futuras gerações, e que exigiria, conquanto, profissionais que estivessem engajados nas novas demandas e complexidades da sociedade, o que se configura no Brasil com a construção do Plano Decenal da Educação para Todos de 1993.

Os elementos que constituíram a identidade do curso de Pedagogia também foram foco de discussão no cenário da recente LDB e dos dispositivos que regulamentariam a profissionalização oferecida pela Pedagogia, posteriormente definida pela Resolução CNE 1/06 e pelos Pareceres CNE CP 5/05 e 3/06, que abordaremos neste capítulo, para tratar do "lugar" 25 que viria a ser destinado à formação dos especialistas.

Saviani (2008) destacou, que assim como muitos outros aspectos da educação, a conquista de uma identidade para o curso de Pedagogia resultaria do enfrentamento que imporíamos sobre a lógica de expropriação da importância intelectual dos profissionais da educação:

\begin{abstract}
A Lei $n^{\circ}$ 9.394, de 20 de dezembro de 1996 que "estabelece as diretrizes e bases da educação nacional", em vigor a partir de sua publicação no Diário Oficial da União de 23 de dezembro de 1996, embora não tenha incorporado dispositivos que claramente apontassem na direção da necessária transformação da deficiente estrutura educacional brasileira, ela, de si, não impede que isso venha a ocorrer. A abertura de perspectivas para a efetivação dessa possibilidade depende da nossa capacidade de forjar uma coesa vontade política capaz de transpor os limites que marcam a conjuntura presente. Enquanto prevalecer na política educacional a orientação de caráter neoliberal, a estratégia da resistência ativa será a nossa arma de luta. Com ela nos empenharemos em construir uma nova relação hegemônica que viabilize as transformações indispensáveis para adequar às necessidades e aspirações da população brasileira (SAVIANI, 2008, p.238).
\end{abstract}

A existência de um destaque para o tratamento da formação dos profissionais da educação, no caso o capítulo VI da LDB, demonstrava a emergência na definição mais clara para a matéria e a concepção ideológica que orientaria a formação daqueles que passavam a ser chamados de profissionais responsáveis pelos processos de gestão educacional, ao invés de especialista em educação como ocorria até esta época.

\footnotetext{
${ }^{25}$ Nos valemos da expressão "lugar" para nos referirmos ao tempo (horas, carga horária, número de disciplinas) e espaço (disciplinas, atividades, estágio) existente e destinado no curso de Pedagogia para a formação em gestão escolar.
} 
Os oito anos que distanciaram a publicação da Lei de Diretrizes e Bases da Educação, da edição da Constituição Federal demonstraram o quanto o texto original, elaborado pelo Senador Darcy Ribeiro, sofrera emendas e alterações substantivas, principalmente no que se referia às formas de financiamento da educação, e as responsabilidades de atendimento da demanda escolar, o que foi denominado de regime de colaboratividade, que implicaria na constituição de sistemas de ensino locais.

Naquele momento, aspectos como a formação dos profissionais da educação, embora abrangidos pela lei, foram tratados de forma mais aligeirada, fato que exigiu a intensos debates e publicação quase imediata da regulamentação da matéria.

Especificamente o texto da Lei 9394/96, em seu artigo 64, dispôs a formação dos profissionais em exercício de atividades do magistério diferentes da docência da seguinte forma:

A formação de profissionais de educação para administração, planejamento, inspeção, supervisão e orientação educacional para a educação básica, será feita em cursos de graduação em Pedagogia ou em nível de pós-graduação, a critério da instituição de ensino, garantida, nesta formação, a base comum nacional (Lei de Diretrizes e Bases da Educação Nacional, art. 64).

Partindo da diretriz legal, nas Instituições de Ensino Superior (IES) de diferentes naturezas (universidades, centros universitários e faculdades isoladas) tornou-se obrigatório agregar aos cursos de Pedagogia, que até então formavam somente professores, também a formação inicial dos profissionais da educação voltados para as atividades de gestão ${ }^{26}$.

\footnotetext{
${ }^{26}$ A partir do início da década de 1990, com a edição da Constituição de 1988, que previa a universalização da formação superior para os professores, o que foi reiterado pela lei 9394/96, embora existissem várias habilitações, era comum os cursos oferecerem habilitações duplas como: educação infantil e séries iniciais, séries iniciais e educação especial, séries iniciais e disciplinas do magistério, e até disciplinas do magistério e de administração escolar, por exemplo.
} 
Todavia, esta determinação inicial e abrangente da LDB não dissolveu os problemas de identidade do curso, sobretudo no que se refere à capacidade e eficácia dos cursos para o atendimento das novas prerrogativas legais.

A concessão desta autonomia às instituições de ensino superior para a organização dos cursos poderia gerar criatividade em novas propostas, ou também propostas abusivas que não contemplassem as necessidades básicas para a formação do pedagogo, implicando na necessidade da publicação de novas diretrizes curriculares para o curso de Pedagogia, evidenciando-se as novas expectativas do ponto de vista da concepção de curso, da profissionalização dos egressos e da articulação entre a atuação na escola, pesquisa e a superação da dicotomia entre teoria e prática.

O fato de se prever, no mesmo artigo 64, que a formação dos profissionais da educação também dar-se-ia em cursos de pós-graduação mostrava-se dissonante com o propósito de que essa formação também ocorresse nos cursos de Pedagogia, o que trouxe novamente as críticas que ocorriam em décadas anteriores para os anos 1990 e os anos que a sucederiam.

Pesquisadores associados a ANFOPE, FORUMDIR e ANPAE congregavam a defesa de que, se os especialistas atuariam como pedagogos, estes deveriam ter a escola como principal local de trabalho, portanto, deveriam conhecer seus contextos, suas lutas e contradições e produção de valores.

Em situação contrária a esta perspectiva, a formação que se propunha permaneceu reafirmando a ruptura entre uma teoria para profissionalização e outra realidade para a profissionalidade ${ }^{27}$, inclusive concebendo o pedagogo como um profissional formado por inúmeras áreas de especialidade, o que

\footnotetext{
${ }^{27}$ Maria Isabel de Almeida, em sua tese de doutoramento pela FE USP (1999), com o trabalho intitulado "O sindicato como instância formadora dos professores: novas contribuições ao desenvolvimento profissional" analisa a possibilidade do desenvolvimento profissional docente dos professores, considerando o papel do sindicato como instância formadora. Nesta tese discute os conceitos de profissionalidade, profissionalismo e profissionalização, inseridos no contexto das atividades de trabalho dos professores, em meio a condições próprias de exercício.
} 
ocorreria caso a formação passasse a ocorrer basicamente em cursos de especialização e não mais habilitações.

Almeida (1999), ao pesquisar o papel dos sindicatos na construção da identidade profissional dos professores, com vistas ao desenvolvimento profissional destes sujeitos, apresenta em sua tese que a profissionalização foi para os professores um processo de busca de valorização e reconhecimento social, e ao mesmo tempo de enfrentamento da proletarização das condições de trabalho, e dos elementos que poderiam conferir seu controle social e cultural sobre a profissão, ou seja, uma forma de profissionalismo docente em crise. Este profissionalização seria, em última análise, a compreensão de como os professores trilham o caminho do seu trabalho, em meio aos desafios contemporâneos, a posição do Estado, e suas condições de trabalho.

Para a pesquisadora a mudança é fator determinante na construção de outra identidade para os professores, de maneira que tenham elementos eficazes para enfrentarem o desgaste de seu reconhecimento social, para entenderem a profissão docente, e ao mesmo tempo reconhecerem o continuum processo de alterações das situações nas quais o magistério tem colocado novos desafios e, portanto, implicando em outra profissionalidade.

Neste sentido, profissionalidade, profissionalização e profissionalismo são ao mesmo tempo categorias distintas da construção da identidade dos profissionais, e neste caso dos professores, mas ao mesmo tempo categorias indissociáveis, que se vinculam respectivamente, ao modo de organizarem seu trabalho, de colocarem em prática aquilo que pensam e como fazem seu ofício; o processo pelo qual constroem seu percurso e história profissional, e deste modo atribuem mais significado ao seu ofício, construindo, inclusive, sua autoimagem; e finalmente seu reconhecimento social, e cultural, sua condição de valorização e prestígio no campo das profissões e do trabalho.

Críticas severas a esta organização curricular passariam a ser feitas desde a edição da LDB de 1996 e, posteriormente, à resolução CNE CP1/2006, a saber, por Pimenta (2001), Freitas (2002), Brzezinski (2002), e Libâneo (2004). 
Estes estudiosos acreditam que ocorria uma forma de tratamento metodológico na estrutura do curso, incorrendo-se na valorização excessiva dos processos de certificação, preterindo-se melhor qualificação, destacandose principalmente a lógica do desenvolvimento das capacidades mais laborais do que as intelectuais, políticas e científicas.

Segundo Almeida (2008), o que fica indicado na LDB é que se deveria tornar referência para as diretrizes curriculares da Pedagogia, uma organização curricular e pedagógica voltada ao desenvolvimento de competências que ultrapassem os limites das escolas e rompam com a idéia de especializações, apenas:

\begin{abstract}
O novo pedagogo deve estar capacitado para ultrapassar os limites do espaço escolar de trabalho, participar da tomada de decisões e atuar criativamente no processo educacional de maneira a construir uma nova sociedade. A base dessa concepção de formação está levando em consideração as transformações sociais, que por sua vez, provoca mudanças no papel atribuído ao professor, bem como aos outros profissionais da escola. Tais transformações tendem à superação das desigualdades educacionais onde 0 profissional possa ter domínio do conhecimento pedagógico, assim como das relações estabelecidas no interior do processo ensino-aprendizagem (ALMEIDA, 2008, p.138).
\end{abstract}

Ao prever em seus artigos 62 e 63, que a formação dos professores não se daria apenas em cursos de graduação, mas também em institutos superiores de educação, estes dispensados da obrigatoriedade da pesquisa, e que os especialistas poderiam ser formados em cursos de pós-graduação, novamente se acenou para o risco da extinção progressiva do curso de Pedagogia, que a rigor, localizava-se num intenso embaraço de sentido e significado, além de papel acadêmico.

Oportunamente, em 1997, o Ministério da Educação se manifestou através do edital 4/97 da Secretaria de Ensino Superior - MEC, reafirmando a permanência da existência da Pedagogia. Para Maciel e Neto (2004), a instauração dos institutos superiores de educação representava um agravamento da situação da formação dos profissionais da educação, além de ser um movimento institucionalmente contraditório: 
Além disso, como aceitar professores formados nos ISEs por um corpo docente composto somente de $10 \%$ de mestres ou doutores, como determina a Resolução CNE/CP n 1/99, enquanto nas universidades essa proporção vem crescendo a ponto de atingir quase $100 \%$ na maioria delas? Aliás, esse é um requisito exigido pelo MEC para a avaliação dos cursos de graduação, de modo que um curso só obtém conceito A se tiver $50 \%$ ou mais de titulados. Não é paradoxal que o mesmo órgão faça exigências diferentes para diferentes instituições formadoras do mesmo profissional? Não corrobora a minha análise acerca do sistema dual de formação? (MACIEL; NETO, 2004, p. 26).

Por meados de 1999, é encaminhada ao Ministério da Educação, pela comissão de especialistas do curso de Pedagogia, uma proposta de diretrizes curriculares para o curso, que indicava eixos norteadores de uma base nacional comum: sólida formação teórica, unidade entre a teoria e a prática, gestão democrática, compromisso crítico baseado no trabalho coletivo e interdisciplinar e a garantia de formação inicial e contínua aos egressos e demais profissionais, então pedagogos. Nas palavras de Silva (2006):

Esse documento indica que o locus privilegiado da formação dos profissionais da educação para atuação na educação básica e superior são a universidade e suas faculdades/centros de educação, os quais devem ter suas estruturas repensadas. Consequentemente, o entendimento é o de manutenção do curso de Pedagogia e demais Licenciaturas, aos quais também se aplica a necessidade de revisão. A orientação vai no sentido de superar, no caso do primeiro, a fragmentação e suas habilitações e, em se tratando de todas as Licenciaturas, a dicotomia atualmente existente entre a formação dos pedagogos e dos demais licenciados. Esses são os únicos limites fixados no documento no que concerne às questões estruturais, uma vez que o mesmo se encaminha na direção de que as próprias instituições formadoras organizem suas propostas curriculares, orientadas por indicações gerais a todos os cursos, destacando-se entre essas a da "base comum nacional" e a da consideração da docência como a base da identidade profissional de todos os profissionais da educação (SILVA, 2006, p.79).

Enquanto tal proposta da Comissão de Especialistas permanecia "congelada" no MEC, por meio da Resolução CNE CP 01/99 foram regulamentados os ISE - Institutos Superiores de Educação - já em situação de crise identitária.

Esta Resolução foi seguida de derradeira expropriação de sentido, e marcada por publicações consideradas ambíguas, culminando com o Parecer CNE CP 09/01, que sugeria o deslocamento da formação de docente para a educação infantil e fundamental do curso de Pedagogia para os IES. 
Silva (2006) denominou de "período de decretos"28 por edição do dispositivo 3276/99, que destinava à Pedagogia a formação de pedagogo não docente, intencionando-se dar sentido ao já alijados institutos de educação.

Tal decreto fora duramente atacado pelos diversos setores da sociedade representados pelo Fórum de Defesa da Formação de Professores ${ }^{29}$, principalmente pelas recentes normas terem destacado os Institutos Superiores de Educação que raramente supririam seus egressos das necessidades de formação requeridas pela amplitude do conhecimento pedagógico, firmando-se basicamente por força de lei, defendida à época pelo Conselho Nacional de Educação, via manifestação em seu parecer:

O outro ponto de destaque nos Artigos 62 e 63 refere-se à criação dos Institutos Superiores de Educação (ISE). Coerente com o princípio de flexibilidade da LDBEN, a Resolução CNE 01/99 deixa em aberto a localização dos ISE - dentro ou fora da estrutura universitária - e os posiciona como instituições articuladoras. Para tanto, determina a existência de uma direção ou coordenação responsável por articular a elaboração, execução e avaliação do projeto institucional, promovendo assim condições formais de aproximação entre as diferentes Licenciaturas e conseqüentemente o desenvolvimento da pesquisa sobre os objetos de ensino. Aborda ainda, dentre outras questões, princípios de formação, competências a serem desenvolvidas, formas de organização dos Institutos atribuindo-lhes caráter articulador, composição de seu corpo docente, carga horária dos cursos e finalidades do Curso Normal Superior. Aos ISE é atribuída a função de oferecer formação inicial de professores para atuar na educação básica (Parecer CNE CP 09/01).

\footnotetext{
${ }^{28}$ A fase da construção da identidade do curso de Pedagogia, que Silva denomina "período dos decretos" estava sob o comando do Ministro da Educação Paulo Renato de Souza, na gestão Fernando Henrique Cardoso, tendo como algumas das políticas educacionais vinculadas ao tema, a implantação dos ISE, o esvaziamento do sentido do curso de Pedagogia, a redução significativa de investimentos na educação superior pública, a valorização de alternativa para a aceleração da formação de professores, dentre outras. Outro exemplo notável foi o decreto $3554 / 2000$, que para reparar o estrago do decreto sobre os Institutos Superiores Educação, que previa a formação "exclusiva" de professores nestas instituições, substituiu a expressão por "preferencialmente".

${ }^{29}$ Este fórum era composto por profissionais da educação associados a Sindicato Nacional dos Docentes de Instituições de Ensino Superior (ANDES), Associação Nacional pela Formação dos Profissionais da Educação (ANFOPE), Associação Nacional de Política e Administração da Educação (ANPAE), (ANPED), Centro de Estudos Educação e Sociedade (CEDES), Fórum Nacional de Diretores de Faculdades de Educação ou Equivalentes das Universidades Públicas Brasileiras (FORUMDIR), além daqueles que integravam o Fórum Nacional em Defesa da Escola Pública (FNDEP), Fórum Paulista dos Profissionais da Educação Básica (FOPPEB), e Fórum Paulista da Educação Infantil (FPEI).
} 
De maneira geral, a forma pela qual seriam desenvolvidas as atividades neste novo modelo de organização institucional, os ISEs pouco atingiram a situação de existência de cursos de formação de professores que excessivamente se dedicavam à prática e se esvaziavam do exercício da pesquisa, nem tampouco à melhoria das Licenciaturas que formavam professores relativamente conhecedores das diversas áreas do conhecimento, mas muito pouco providos de saberes pedagógicos e condição didática apropriada para a docência.

No ano de 2001, um grupo de educadores que compunham a Comissão de Especialistas em Educação, constituída pelo Conselho Nacional, apresenta a este colegiado uma proposta de diretrizes curriculares para o curso, que tendo como base a docência incorporaria também a formação do pedagogo para atividades não docentes, ainda que tal proposta segmentasse a docência, enfatizando-se a instrumentalização metodológica.

Poucos esforços por parte do Conselho Nacional de Educação eram visíveis na direção de dar distinção ao curso de Pedagogia, o que fica claro com a aprovação do parecer CNE CP 09/01 ${ }^{30}$, que trazia as diretrizes para a formação inicial de professores da educação básica em nível superior, enfatizando a prática profissional e a criação de outras alternativas para a formação dos professores, quase que se eximindo de referência ao curso de Pedagogia, como destacamos:

A formação de professores deve ser realizada como um processo autônomo, em curso de Licenciatura plena, numa estrutura com identidade própria. - Os cursos de formação de professores devem manter estreita parceria com institutos, departamentos e cursos de áreas específicas.

- As escolas de formação de professores devem trabalhar em interação sistemática com as escolas do sistema de educação básica, desenvolvendo projetos de formação compartilhados.

- As escolas de formação devem garantir, com qualidade e em quantidade suficiente, recursos pedagógicos, tais como: bibliotecas, laboratórios, videoteca, entre outros, além de recursos de tecnologia da informação, para

\footnotetext{
${ }^{30} \mathrm{Na}$ ocasião, o parecer fora aprovado pelo Conselho Pleno, tendo sido seus relatores os conselheiros Edla de Araújo Lira Soares, Éfrem de Aguiar Maranhão, Eunice Ribeiro Durham, Guiomar Namo de Mello, Nelio Marco Vincenzo Bizzo e Raquel Figueiredo Alessandri Teixeira (Relatora), Silke Weber (Presidente).
} 
que formadores e futuros professores realizem satisfatoriamente as tarefas de formação.

- As escolas de formação devem garantir iniciativas, parcerias, convênios, entre outros, para a promoção de atividades culturais.

- As instituições de ensino superior não detentoras de autonomia universitária deverão criar Institutos Superiores de Educação para congregar os cursos de formação de professores que ofereçam Licenciaturas em Curso Normal Superior para docência multidisciplinar na educação infantil e anos iniciais do ensino fundamental ou Licenciaturas para docência nas etapas subsequentes da educação básica (Parecer CNE CP 09/2001, item 2.4)

Brzezinsky (1996) anunciou que embora concordasse com a necessidade da atuação do pedagogo em diversos espaços da sociedade, condição esta que requereria saberes pedagógicos, o sentido específico da profissionalidade dos pedagogos seria a educação formal ou não formal, inserindo-se, portanto, no campo educacional e, como consequência, mais precisamente na escola.

Baseado neste modo de compreender o foco da atuação dos profissionais da educação, e dada a característica complexa da instituição escolar, não se poderia prescindir da articulação entre os núcleos de formação e suas relações com os locais de atuação.

A idéia de articulação de núcleos formativos foi determinante para refutar a lógica de habilitações restritivas de cada ofício, principalmente quando adquiridas meramente em cursos sequenciais, uma contradição se considerarmos a formação do pedagogo como profissional que deve atuar na perspectiva da integralidade.

Gatti e Barreto (2009), em uma pesquisa intitulada Professores no Brasil: impasses e desafios ${ }^{31}$, reiteram que o que vem se consolidando é uma relativa

\footnotetext{
${ }^{31}$ A pesquisa "Professores do Brasil: impasses e desafios", de autoria de Bernardete Angelina Gatti e Elba Siqueira de Sá Barreto (2009), com financiamento da UNESCO, dedicaram-se ao levantamento do Estado da Arte das licenciaturas no Brasil, inclusive da Pedagogia. Neste estudo, as pesquisadoras trazem elementos e análises referentes a estrutura das licenciaturas, as propostas de formação dos docentes, seu potencial de atratividade profissional, as licenciaturas ofertadas na modalidade à distancia, e a relação das licenciaturas com as possibilidades de carreira no magistério. Embora não tenha como foco a aproximação com a
} 
ênfase na formação para a docência, expressando que mesmo havendo nas diretrizes curriculares indicação para a formação dos especialistas da educação no curso, esta se daria numa forma de complementaridade, já que desde o início da década tem havido destaque ao debate sobre a formação docente, como uma forma de priorizar as possibilidades de construção de situações de aprendizagem mais eficazes.

Demonstra-se que, se em outro momento histórico destacou-se o "lugar" da formação dos especialistas da educação, se na Pedagogia, nos cursos de complementação a esta licenciatura, ou em situações de pós-graduação, nestes últimos anos passaria a se discutir mais enfaticamente a formação dos professores, o que deixaria para segundo plano o lugar e o modo de profissionalização dos que atuariam em atividades de planejamento, coordenação, administração ou supervisão em educação:

\begin{abstract}
Em 2005 instituíram-se as Diretrizes Curriculares Nacionais para a Formação de Professores para a Educação Básica, cuja redação centra-se no desenvolvimento de competências pessoais, sociais e profissionais dos professores. Postulam essas diretrizes que a formação de professores que atuarão nos diferentes níveis e modalidades da educação básica observará alguns princípios norteadores desse preparo para o exercício profissional específico, que considerem, de um lado, a formação de competências necessárias à atuação profissional, como foco do curso, a coerência entre a formação oferecida e a prática esperada do futuro professor, e, de outro, a pesquisa, como foco no ensino e na aprendizagem, para compreensão do processo de construção do conhecimento. As aprendizagens deverão ser orientadas pelo princípio da ação-reflexão-ação tendo a resolução de situações-problema como uma das estratégias didáticas privilegiadas (Brasil. MEC/CNE, 2002, apud GATTI; BARRETO, 2009).
\end{abstract}

A primeira década de 2000, realmente é tida como obscura em relação à formação dos gestores escolares, algo que se colocava fortemente como marca do curso de Pedagogia, na interpretação de Silva (2006). Inclusive, se observássemos o campo de atuação do pedagogo em atividades não docentes, identificaríamos também a incerteza sobre o significado destes profissionais na melhoria das condições de organização da escola pública e do

formação dos gestores escolares, mas sim dos docentes, apresenta aspectos que corroboram a realidade do pedagogo, num sentido lato. 
sistema, tanto como para a melhoria da profissionalidade dos pedagogos, inclusive docentes.

Como cita a pesquisadora, a respeito do Parecer CNE CP 09/01, esta regulamentação geraria ainda mais dúvidas não somente sobre de que modo seriam formados tais profissionais, mas também o sentido de sua prática profissional, e como o que identificaria o que fariam no processo educacional:

Há, na verdade, uma grande apreensão a respeito dos novos rumos a serem traçados para o curso de Pedagogia no Brasil, uma vez que, até o momento, o que existe é o silêncio, ou então documentos que determinam o que ele não pode fazer, ou o que ele não tem a preferência para fazer, ou até que optam por seu nome não aparecer. O que se tem questionado é o significado de tudo. Em contrapartida, o que se tem como certo quanto às funções do curso de Pedagogia não parece ser muito promissor; a formação de professores para administração, planejamento, inspeção, supervisão e orientação educacional, previstas pelo artigo 64 da LDB, parece ter os dias contados nas instituições que possam assumi-la em nível de pós-graduação (...) (SILVA, 2006, p.88).

O contexto teórico e legal que era proposto pelas novas diretrizes, já no início da última década, atribuía a cada ISE a organização do curso de Pedagogia na forma que a prouvesse melhor, ainda no âmbito dos dispositivos legais anteriores às Diretrizes Curriculares do Curso de Pedagogia, permanecendo o descompasso entre a proposta curricular para a formação do pedagogo e a identidade profissional dos mesmos.

Novamente em 2004, a ANFOPE elabora um documento questionando o Conselho Nacional de Educação ${ }^{32}$ sobre a descaracterização do curso de Pedagogia. Concordamos com a análise realizada por Assis (2007) quando afirma que esta situação gerava uma expressiva dicotomização da formação dos profissionais da educação, que de certa forma, deixavam de ter um lócus

${ }^{32}$ Com a edição da Constituição Federal, que culminou do ponto de vista educacional na edição da Lei de Diretrizes e Bases da Educação Nacional 9394/96, o então Conselho Federal de Educação, para a nomenclatura de Conselho Nacional de Educação, criado em 1995, pela Lei Federal 9.131, uma mudança que não tratava apenas de alteração de expressão, mas da concepção de Estado Nacional que passa a vigorar, com a premissa do fortalecimento dos pactos de colaboratividade para a garantia dos direitos sociais previstos para a efetiva condição de nação democrática. O referido conselho passa a ter o papel não mais de normatização especialmente, para assumir as funções também de planejamento de sistema nacional de educação, formulação e avaliação das políticas públicas, e responsável pelas diretrizes educacionais gerais, cabendo aos entes federados a regulamentação destas. 
acadêmico-científico privilegiado, que deveria ser o curso de Pedagogia. Segundo a pesquisadora:

A característica maior que a educação tem priorizado hoje em dia, que é a do diálogo entre várias áreas do conhecimento, não condiz com a exigência formativa especializada, aliás, vai de encontro com ela, pois como cobrar o reconhecimento da existência e possibilidade de se trabalhar com trans/inter/multidisciplinaridade, se a própria formação do professor ainda é compartimentada, cartesiana (ASSIS, 2007, p. 107).

Com as sucessivas pressões expressas pelas associações de pesquisadores e profissionais da educação, frente à conflituosidade que marcava a "(des) identidade" do curso de Pedagogia, o Ministério da Educação publicou em 2005 a minuta da Resolução que traria as diretrizes curriculares para o curso.

Tal documento fora intensamente criticado pelos colegiados e órgãos de representação dos profissionais da educação e pedagogos, pois permanecia com as intenções de esvaziamento do curso, que até então vinham sendo evocadas e, sobretudo, ao destinar ao curso basicamente à formação docente.

Desta feita, no mesmo ano, decorrente do VII Seminário Nacional sobre Formação de Profissionais da Educação, a ANFOPE, ANPED, FORUMDIR, CEDES e ANPAE publicam documento sobre os vários aspectos que refutavam a versão preliminar editada pelo ministério, reforçando as críticas já feitas desde o final da década passada e, ao mesmo tempo, enfatizavam o que julgavam condição sine qua non nas mesmas diretrizes:

a) sólida formação teórica, inter e transdisciplinar sobre o fenômeno educacional e seus fundamentos históricos, políticos e sociais, promovendo a articulação e domínio dos saberes para a compreensão crítica da sociedade brasileira e da realidade educacional, e ainda, a apropriação do processo de trabalho pedagógico;

b) interação teórica e prática, que resgata a práxis da ação educativa, como elemento inerente ao trabalho pedagógico, tendo a docência como base da formação profissional;

c) a pesquisa como princípio formativo e epistemológico, eixo da organização e desenvolvimento do currículo;

d) gestão democrática e trabalho coletivo como base para a organização do trabalho pedagógico em contextos educativos escolares e não-escolares;

e) compromisso social, ético, político e técnico do profissional da educação, voltado à formação humana e referenciada na concepção sócio-histórica da educação e nas lutas desses profissionais articuladas com os movimentos sociais;

f) articulação entre a formação inicial e continuada do profissional da educação;

g) avaliação permanente e contínua dos processos de formação. 
(Documento final do VII Seminário Nacional sobre a formação dos profissionais da Educação).

Realizadas as análises pelo Conselho Nacional de Educação, diante da quase obrigatoriedade de acolher, ao menos parcialmente, as intensas críticas dos educadores, em dezembro de 2005 foi aprovado o Parecer CNE CP 05/05, que mesmo incorporando sugestões dos segmentos citados anteriormente nesta apreciação preliminar do conselho, propunha que a formação dos especialistas fosse realizada nos cursos de pós-graduação.

Demonstrando a influência conservadora nos rumos da educação, esta proposição aproximara-se como já havia sido proposto nas décadas de 1960 e 1970, o que viria a contrariar tanto a posição das entidades, como incoerente frente ao artigo 64 da Lei de Diretrizes e Bases da Educação 9394/96, sobretudo ao reconhecer a importância do saber pedagógico que transborda a docência, mas definindo o curso para tal finalidade:

\begin{abstract}
$\mathrm{Na}$ aplicação destas Diretrizes Curriculares, há de se adotar, como referência, o respeito a diferentes concepções teóricas e metodológicas próprias da Pedagogia e àquelas oriundas de áreas de conhecimento afins, subsidiárias da formação dos educadores, que se qualificam com base na docência da Educação Infantil e dos anos iniciais do Ensino Fundamental. Assim concebida, a formação em Pedagogia inicia-se no curso de graduação, quando os estudantes são desafiados a articular conhecimentos do campo educacional com práticas profissionais e de pesquisa, estas sempre planejadas e supervisionadas com a colaboração dos estudantes. Tais práticas compreendem tanto o exercício da docência como o de diferentes funções do trabalho pedagógico em escolas, o planejamento, a coordenação, a avaliação de práticas educativas em espaços não-escolares, a realização de pesquisas que apóiem essas práticas. Nesta perspectiva, a consolidação da formação iniciada terá lugar no exercício da profissão que não pode prescindir da qualificação continuada (Parecer CNE CP 05/05).
\end{abstract}

Como virtude, o Parecer CNE CP 05/05 reconhecia a complexidade da formação dos pedagogos e os desafios que se colocavam para a garantia de padrões de exercício profissional mais alinhados às demandas educacionais e às reivindicações históricas sobre a necessidade de articulação do curso de Pedagogia, com a complexidade social, e o reconhecimento de que ser pedagogo decorreria em processos de competência para compreenderem a 
cultura escolar, as políticas educacionais, e as contradições do mundo político e econômico:

Para a formação do licenciado em Pedagogia é central o conhecimento da escola como uma organização complexa que tem a função social e formativa de promover, com equidade, educação para e na cidadania (...). De outro lado, espera-se que forneçam informações para políticas destinadas à Educação Infantil, aos anos iniciais do Ensino Fundamental, bem como à formação de professores e de outros educadores para essas etapas de escolarização. Políticas essas que busquem garantir, a todos, o direito à educação de qualidade, em estabelecimentos devidamente instalados e equipados, gerida por profissionais qualificados e valorizados (Parecer CNE CP 05/05).

Neste mesmo dispositivo, o Conselho Nacional de Educação apontou uma série de habilidades e competências que deveriam ser garantidas aos egressos do curso de Pedagogia, estas não se restringindo apenas às atividades de docência, o que se colocaria como uma contradição no que se colocava como finalidade para o curso.

Como dizer, previa-se a formação de docente, mas propondo a garantia de competências para a organização do projeto educativo e da instituição escolar, ou seja, a gestão. Estava anunciado um currículo inchado para um curso que passara a sofrer a redução do tempo para até três anos, em muitas instituições.

Segundo o mesmo Parecer CNE CP 05/05, o perfil dos gestores deveria ser constituído por competências que lhes pudessem assegurar a atuação em diferentes campos de atuação, que se refeririam à docência e as atividades de gestão:

O campo de atuação do licenciado em Pedagogia deve ser composto pelas seguintes dimensões:

- docência na Educação Infantil, nos anos iniciais do Ensino Fundamental, nas disciplinas pedagógicas do curso de Ensino Médio na modalidade Normal, assim como em Educação Profissional, na área de serviços e apoio escolar, além de em outras áreas nas quais conhecimentos pedagógicos sejam previstos;

- gestão educacional, entendida numa perspectiva democrática, que integre as diversas atuações e funções do trabalho pedagógico e de processos educativos escolares e não escolares, especialmente no que se refere ao planejamento, à administração, à coordenação, ao acompanhamento, à avaliação de planos e de projetos pedagógicos, bem como análise, formulação, implementação, acompanhamento e avaliação de política públicas e institucionais na área de educação; 
- produção e difusão do conhecimento científico e tecnológico do campo educacional (Parecer CNE CP 05/05).

Contudo, contrariamente ao que seria esperado do Parecer CNE CP 05/05, foi enfaticamente destacado na proposta de resolução para as Diretrizes Curriculares para o Curso de Pedagogia, que este não seria o espaço privilegiado para a formação dos profissionais que desenvolveriam atividades do magistério, além da docência, embora aos egressos fossem garantidos conhecimentos sobre estas atividades, durante do curso:

Art. 14. A formação dos demais profissionais de educação, nos termos do art. 64 da Lei $n^{\circ}$ 9.394/96, será realizada em cursos de pós-graduação, especialmente estruturados para este fim, abertos a todos os licenciados.

Parágrafo único. Os cursos de pós-graduação poderão ser disciplinados pelos respectivos sistemas de ensino, nos termos do art. 67 da Lei $n^{\circ}$ 9.394/96 (Parecer CNE CP 05/05, art. 14 do Projeto de Resolução).

Como resultado de mais este momento de debate sobre o curso de Pedagogia, no qual podemos destacar que, uma das preocupações residentes e que nos move nesta pesquisa, seria o "lugar" destinado à formação dos profissionais da gestão escolar no curso de Pedagogia, questão esta que fora novamente publicada também no Parecer CNE CP 03/06 ${ }^{33}$, em fevereiro de 2006, resultante do reexame dos documentos anteriores.

Desta revisão legal, retornou a importância de se fundamentar a formação a partir do princípio da integralidade da atuação profissional, tanto no campo da docência, como nas atividades relacionadas aos processos de gestão da educação, além daquelas atividades que requerem saberes pedagógicos:

Essa redação procura dirimir qualquer dúvida sobre a eventual não observância do disposto no art. 64 da Lei no 9.394/1996, ou seja, assevera que a Licenciatura em Pedagogia realiza a formação para administração,

${ }^{33}$ Este parecer, de autoria das conselheiras Clélia Brandão Alvarenga Claveiro e Petronilha Beatriz Oliveira Gonçalves e Silva, reafirma a perspectiva de ênfase na formação dos docentes no curso de Pedagogia, mas incorpora a importância do curso também prover os egressos de conhecimentos, saberes e instrumentos relacionados às atividades de gestão da educação, em diferentes campos de atuação. 
planejamento, inspeção, supervisão e orientação educacional, em organizações (escolas e órgãos dos sistemas de ensino) da Educação Básica e também estabelece as condições em que a formação pós-graduada para tal deve ser efetivada. Outrossim, que devem ser observadas igualmente as disposições do Parágrafo Único do art. 67 da mesma Lei $n^{\circ}$ 9.394/96, no sentido de que a experiência docente é pré-requisito para o exercício profissional de quaisquer outras funções de magistério, nos termos das

normas de cada sistema de ensino. Fica, portanto, reiterada a concepção de que a formação dos profissionais da educação, para funções próprias do magistério e outras, deve ser baseada no princípio da gestão democrática (obrigatória no ensino público, conforme a CF, art. 206-VI; LDB, art. $3^{\circ}$-VIII) e superar aquelas vinculadas ao trabalho em estruturas hierárquicas burocráticas. Por conseguinte, como bem justifica o Parecer CNE/CP $n^{\circ}$ $5 / 2005$, em tela, sendo a organização escolar eminentemente colegiada, cabe prever que todos os licenciados possam ter oportunidade de ulterior aprofundamento da formação pertinente, ao longo de sua vida profissional. Não mais cabe, como outrora (na vigência da legislação anterior - Lei $n^{\circ}$ 5.540/1968 e currículos mínimos), conceber a formação para as funções supracitadas como privativas dos Licenciados em Pedagogia e, a propósito, este Conselho já aprovou e designou comissão para emitir parecer sobre diretrizes para a formação dos profissionais da educação em relação aos arts. 64 e 67, parágrafo único, da Lei nº 9.394/96 (Parecer CNE CP 03/06).

Apesar de compactuarmos com a manifestação do Conselho Nacional da Educação, no que se refere à incorporação da formação dos demais profissionais do magistério no curso de Pedagogia, decisão esta que de alguma forma reconheceu a condição própria e adequada do curso para dedicar-se à profissionalização dos gestores escolares, o modo de pensar e propor a formação dos demais profissionais referidos no artigo 64 da lei 9394/96, como já citamos anteriormente, não seria solucionado por publicação legal.

Tornou-se temerário, destinar à Pedagogia todas as possibilidades de profissionalização inicial dos egressos, em diversos campos de ofício, sem estabelecer padrões de suporte curricular que assegurasse tal formação, como aprofundaremos adiante nesta pesquisa.

A própria declaração de voto contrário, ao projeto de Resolução, por parte do conselheiro Francisco Aparecido Cordão demonstraria, em certa parte, o risco do curso torna-se uma licenciatura intensamente genérica, fomentando o desprestígio social, acadêmico e científico do curso: 
O preâmbulo do Projeto de Resolução anexo ao Parecer CNE/CP n ${ }^{\circ}$ 5/2005 claramente define que este regulamenta o art. 62 da LDB, isto é, formação de docentes em cursos de Licenciatura para atuar na Educação Básica. O referido Parecer não disciplina o art. 64 da LDB, que trata da formação de outros profissionais de educação que não os professores. Ademais, para o exercício profissional dessas outras funções, de acordo com o parágrafo único do art. 67, "a experiência docente é pré-requisito". Nesses termos, julgo muito mais adequada, para contemplar as preocupações em relação ao art. 64 da LDB, a supressão pura e simples do referido art. 14 do Projeto de Resolução anexo ao Parecer CNE/CP $n^{\circ}$ 5/2005. A emenda retificativa proposta pela Comissão Bicameral de Formação de Professores transforma o curso de Pedagogia em um curso genérico e desfigurado, sem condições de contribuir efetivamente tanto para a valorização dos professores e da sua formação inicial quanto para o aprimoramento da Educação Básica no Brasil (Declaração de voto no Parecer CNE CP 03/06).

Com o reexame apresentado pelo Parecer CNE CP 03/06, definiu-se que a Pedagogia deveria ser também o lócus de formação dos profissionais que atuariam nas atividades de planejamento, coordenação, administração, supervisão e assessoramente pedagógico; entretanto, guardados tais avanços sobre a finalidade da formação no curso, que podemos considerar uma conquista relevante, do ponto de vista do reconhecimento da particular importância da Pedagogia, ficando estabelecido pelas diretrizes do curso que:

Art. $4^{\circ}$ O curso de Licenciatura em Pedagogia destina-se à formação de
professores para exercer funções de magistério na Educação Infantil e nos
anos iniciais do Ensino Fundamental, nos cursos de Ensino Médio, na
modalidade Normal, de Educação Profissional na área de serviços e apoio
escolar e em outras áreas nas quais sejam previstos conhecimentos
pedagógicos.
Parágrafo único. As atividades docentes também compreendem participação
na organização e gestão de sistemas e instituições de ensino, englobando:
I. planejamento, execução, coordenação, acompanhamento e avaliação de
tarefas próprias do setor da Educação;
II. planejamento, execução, coordenação, acompanhamento e avaliação de
projetos e experiências educativas não-escolares;
III. produção e difusão do conhecimento científico-tecnológico do campo
educacional, em contextos escolares e não-escolares (Resolução CNE CP
01/06).

Mas, na realidade, nem tudo seria de fato satisfatório, posto que a própria identidade do curso assentada exclusivamente na forma de licenciatura, o que traria virtudes, no que se refere à compreensão pedagógica da formação, mas também entraves relacionados ao tratamento metodológico e curricular que seria dado ao curso. Entretanto, o texto da Resolução CNE CP 01/06, das 
Diretrizes Curriculares Nacionais para o Curso de Pedagogia, passou a constar o seguinte teor em seu artigo 14:

Art. 14. A Licenciatura em Pedagogia nos termos do Parecer CNE/CP $n^{\circ}$ 5/2005 e desta Resolução assegura a formação de profissionais da educação prevista no art. 64 , em conformidade com o inciso VIII do art. $3^{\circ}$ da Lei $n^{\circ}$ 9.394/96.

$\S 1^{\circ}$ Esta formação profissional também poderá ser realizada em cursos de pós-graduação,

especialmente estruturados para este fim e abertos a todos os licenciados.

$\S 2^{\circ}$ Os cursos de pós-graduação indicados no $\S 1^{\circ}$ deste artigo poderão ser complementarmente disciplinados pelos respectivos sistemas de ensino, nos termos do Parágrafo único do art. 67 da Lei nº 9.394/96.

Todo o movimento em prol da definição de diretrizes curriculares para a Pedagogia fora turbulento, antagônico e de certa forma, marcado por sucedâneos desencontros de proposições, ora pela louvável pluralidade de concepções políticas, pedagógicas e científicas, ora lamentavelmente por pressões externas à escola.

Restariam, pois, significativas arestas na versão final dos Pareceres CNE CP 05/05 e 03/06 do Conselho Nacional, que fundamentaram a resolução das diretrizes para o curso, pois embora tenha mantido algumas situações conflituosas no debate sobre o reconhecimento do pedagogo, estabelecendo a docência como base comum, apresentaram aspectos positivos para a identidade do pedagogo, a exemplo de não ser formado exclusivamente para a docência.

Estruturamos, a seguir, uma comparação sobre a finalidade prevista para o curso de Pedagogia, a partir dos dispositivos legais que, à época, foram vinculados ao estabelecimento das Diretrizes Curriculares: 


\section{Alterações legais nos dispositivos geradores das Diretrizes Curriculares Nacionais para a Pedagogia (1)}

\begin{tabular}{|c|c|c|c|c|}
\hline & $\begin{array}{c}\text { Minuta das Diretrizes } \\
\text { Março/2005 }\end{array}$ & $\begin{array}{c}\text { Proposta da ANFOPE } \\
\text { para a minuta }\end{array}$ & $\begin{array}{c}\text { Parecer CNE CP 5/05 } \\
\text { Dezembro/2005 }\end{array}$ & $\begin{array}{c}\text { Resolução CNE CP } \\
01 / 06 \\
\text { Maio/2006 }\end{array}$ \\
\hline
\end{tabular}

Não coincidentemente, o fato de se estabelecer, a todo o momento, a docência como objeto prioritário da formação da Pedagogia, posição contrária à defendida por muitas instituições de profissionais da educação, os docentes 
passaram a ser vistos como foco central de ditas reformas dedicadas à educação brasileira.

Tais reformas permaneceram dedicadas às ações relacionadas aos profissionais da educação, evidenciando-se uma lógica da responsabilização permanente dos professores, contribuindo para a intensificação do trabalho e destaque a uma formação que priorize o domínio de conhecimentos técnicos e práticos, menos científicos e intelectuais.

Neste contexto se constituíram as Diretrizes Curriculares Nacionais para o Curso de Pedagogia, que na compreensão de Vargas (2007), localiza pontualmente a formação dos pedagogos no contexto ideológico das políticas educacionais das últimas décadas que é marcado por coerção e controle sobre o trabalho docente, como alternativa de fortalecimento de um discurso de qualidade que normalmente se pauta em exigências imediatistas.

Esta idéia de formação e atuação profissional provocaria concepção do pedagogo como "um prático", que supostamente com conhecimentos técnicos é alijado de verdadeiros debates e decisões sobre seu ofício, que aprofunda a condição de desprofissionalização docente e dos demais profissionais do magistério, apontando para uma formação mais instrumentalista, e uma profissionalidade mais cartesiana e tecnificada.

Em 15 de maio de 2006, é publicada a resolução que passaria a conceber a Pedagogia como "lugar" para a formação dos docentes da educação infantil e séries iniciais do ensino fundamental e também dos profissionais que atuariam nos processos de gestão educativa. Isto representou, concomitantemente, um avanço acerca do papel do pedagogo nas diferentes situações de trabalho pedagógico, mas também dedicou uma amplitude formativa considerável ao curso de Pedagogia, o que certamente contribuiria para a continuidade da situação híbrida de organização desta formação.

Esta atribuição de muitas responsabilidades e finalidades para o curso, principalmente acerca das competências desejadas dos egressos, torna-se ainda mais problemática à medida que houve pouca clareza acerca da 
organização curricular que deveria ser tomada como referência para os "novos" cursos que ora formariam docentes, gestores e pedagogos que atuariam em atividades que requerem saberes de natureza pedagógica, o que pôs em risco novamente a Pedagogia, pela relativa generalização em diversos aspectos do curso, como no caso da regulamentação, por exemplo, da carga horária:

Art. $7^{\circ} \mathrm{O}$ curso de Licenciatura em Pedagogia terá a carga horária mínima de 3.200 horas de efetivo trabalho acadêmico, assim distribuídas:

I - 2.800 horas dedicadas às atividades formativas como assistência a aulas, realização de seminários, participação na realização de pesquisas, consultas a bibliotecas e centros de documentação, visitas a instituições educacionais e culturais, atividades práticas de diferente natureza, participação em grupos cooperativos de estudos;

II - 300 horas dedicadas ao Estágio Supervisionado prioritariamente em Educação Infantil e nos anos iniciais do Ensino Fundamental, contemplando também outras áreas específicas, se for o caso, conforme o projeto pedagógico da instituição;

III - 100 horas de atividades teórico-práticas de aprofundamento em áreas específicas de interesse dos alunos, por meio, da iniciação científica, da extensão e da monitoria (Lei 9394/96, artigo $7^{\circ}$ )

É considerável que não apenas as questões relacionadas à carga horária, perfil do egresso, ou capacidades a serem asseguradas pelo curso de Pedagogia, mas também a carga horária, integralmente e sua distribuição, foi motivo de discussão, divergência e diferenciação pelos documentos legais, durante todo o período de construção da resolução normatizadora, como organizamos na comparação, a seguir: 


\section{Alterações legais nos dispositivos geradores das Diretrizes Curriculares Nacionais para a Pedagogia (2)}

\begin{tabular}{|c|c|c|c|c|}
\hline & $\begin{array}{c}\text { Minuta das Diretrizes } \\
\text { Março/2005 }\end{array}$ & $\begin{array}{c}\text { Proposta da ANFOPE } \\
\text { para minuta }\end{array}$ & $\begin{array}{c}\text { Parecer CNE CP 5/05 } \\
\text { Dezembro/2005 }\end{array}$ & $\begin{array}{c}\text { Resolução CNE CP } \\
01 / 06 \\
\text { Maio/2006 }\end{array}$ \\
\hline
\end{tabular}

Após a homologação da Resolução CNE CP 01/06, ficou determinado explicitamente que tal formação não se restringiria à docência, inclusive com a realização de atividades de estágio supervisionado em atividades relacionadas às práticas de gestão dos processos educativos e pedagógicos:

IV - estágio curricular a ser realizado, ao longo do curso, de modo a assegurar aos graduandos experiência de exercício profissional, em ambientes escolares 
e não-escolares que ampliem e fortaleçam atitudes éticas, conhecimentos e competências:

a) na Educação Infantil e nos anos iniciais do Ensino Fundamental, prioritariamente;

b) nas disciplinas pedagógicas dos cursos de Ensino Médio, na modalidade Normal;

c) na Educação Profissional na área de serviços e de apoio escolar;

d) na Educação de Jovens e Adultos;

e) na participação em atividades da gestão de processos educativos, no planejamento, implementação, coordenação, acompanhamento e avaliação de atividades e projetos (g.n) educativos;

f) em reuniões de formação pedagógica. (Lei 9394/96,artigo 13).

Gatti e Barreto (2009), ao avaliarem o conteúdo que configura os cursos de Pedagogia com o advento das diretrizes curriculares para o curso, a partir de um longo estudo estrutural, mesmo que a finalidade não fosse discutir a formação dos gestores escolares, mas sim dos docentes, sugerem que:

A complexidade curricular exigida para esse curso é grande, notando-se também, pelas orientações da resolução citada, a dispersão disciplinar que se impõe, em função do tempo de duração do curso e sua carga horária, dado que ele deverá propiciar "a aplicação ao campo da educação, de contribuições, entre outras, de conhecimentos como filosófico, o histórico, o antropológico, o ambiental-ecológico, o psicológico, o linguístico, o sociológico, o político, o econômico, o cultural", e englobar todos os aspectos previstos pelo o artigo $4^{\circ}$, parágrafo único, de referida resolução (GATTI; BARRETTO, 2009, p. 49).

Julgamos que o problema a ser enfrentado não tratava apenas da inclusão ou não de determinado campo de atuação no rol de possibilidades de formação no curso de Pedagogia ou simplesmente de considerá-lo como um Bacharelado ou Licenciatura, correndo-se o risco de se simplificar a complexidade do caráter pedagógico, curricular, político e científico que devem orientar o processo de formação do pedagogo.

Do ponto de vista da legalidade, o reconhecimento da formação dos gestores escolares, nos termos do artigo 64 da LDB, incorporada por norma à Pedagogia como objeto integrante da constituição profissional do pedagogo e não condição de complementação do curso representou um avanço, porém não dissolveu por imposição legal os dilemas formativos e curriculares.

A diversidade de posições acerca do foco que deveria ser atribuído ao curso de Pedagogia, não se restringiu às manifestações do Conselho Nacional 
de Educação, mas também permeou o que seria defendido pelas entidades de educadores, inclusive em como se deveria postular a formação para o exercício das atividades de gestão, tal qual a diversificação demonstrada pelos documentos, como segue:

\section{Alterações legais nos dispositivos geradores das Diretrizes Curriculares Nacionais para a Pedagogia (3)}

\begin{tabular}{|c|c|c|c|c|}
\hline & $\begin{array}{c}\text { Minuta das Diretrizes } \\
\text { Março/2005 }\end{array}$ & $\begin{array}{l}\text { Proposta da ANFOPE } \\
\text { para minuta }\end{array}$ & $\begin{array}{c}\text { Parecer CNE CP 5/05 } \\
\text { Dezembro/2005 }\end{array}$ & $\begin{array}{c}\text { Resolução CNE CP } \\
01 / 06 \\
\text { Maio/2006 }\end{array}$ \\
\hline
\end{tabular}

Tal movimento de posições divergentes acerca da nova configuração da Pedagogia trazia os rescaldos do histórico dilema sobre a gestão como atividade do pedagogo, logo indissociável deste processo de formação inicial; ou como conjunto de saberes constituintes da identidade profissional do docente, que ora também tornar-se-ia competente para lidar com as questões da gestão; ou ainda, uma forma quase paralela de exercício profissional nas escolas, ainda que baseada no domínio de saberes pedagógicos. 
Tornar-se-ia imperativo a organização de cursos que não apenas incorporassem a possibilidade de certificação dos egressos para esta modalidade de formação, mas sim que propusessem um currículo também comprometido com esta dimensão da profissionalização do pedagogo, tanto no aspecto dos referenciais teóricos presentes no curso, quanto em relação às demais práticas formativas e atividades complementares propostas, considerando portanto os diferentes escopos de ofício a ser incorporados pelos pedagogos nas diferentes atividades profissionais.

Fica posto o desafio da superação da dicotomia historicamente existente no curso de Pedagogia, que aparentemente situa-se entre o "formar-se e o fazer", algo similar à dissonância entre a teoria e a prática, que se concretiza no plano curricular dos cursos e na intensidade das críticas sobre a fragilização presente nos processos formativos propostos, que carecem não raramente de condições, saberes, conteúdos e experiências que sejam expressivas para a resolução de questões que se colocam no âmbito da educação e das práticas pedagógicas, não apenas escolares, nem tampouco docentes, visão esta que procura romper com um conceito de atuação do pedagogo, como um profissional tecnólogo, algo extremamente refutável.

É a este respeito que prosseguiremos nesta pesquisa, apresentando os elementos estruturais que estão presentes numa amostragem representativa de cursos de Pedagogia no Brasil, demonstrando como eles se organizam no período pós edição das Diretrizes Curriculares para o Curso de Pedagogia, de maneira que analisaremos a garantia da formação dos profissionais do magistério que se dedicam às atividades de planejamento, coordenação, administração, inspeção, supervisão e orientação educacional para a educação básica.

A base de análise dos cursos será a constatação de tendências e possibilidades de contribuir para o fortalecimento da formação do pedagogo no exercício destas atividades, a partir de uma perspectiva articulada entre a profissionalização e a profissionalidade dos pedagogos, inclusive, considerando a existência deste campo epistemológico próprio de formação. 


\subsection{0 sentido e o significado dado à Pedagogia: alguns elementos sobre esta licenciatura pós Diretrizes Curriculares Nacionais}

Através da reconstrução do processo histórico que caracterizou o curso de Pedagogia, notamos que sua organização sempre esteve diretamente ligada às tendências históricas da educação, sobretudo em relação aos marcos legais, especificamente as três últimas Leis de Diretrizes e Bases da Educação Nacional, o que embora possa parecer óbvio, expõe a relação entre a complexidade da educação no país e o reflexo sobre a formação dos pedagogos.

Há que se apontar que tais movimentos da educação e do curso de Pedagogia influenciaram os movimentos da escola no que se refere a sua organização e as exigências dos profissionais que lá atuam.

Não se pode ignorar que, por outro lado, tais movimentos escolares também influenciaram a discussão sobre o curso de Pedagogia. Como deixa claro Pinto (2006), o pedagogo é o profissional essencialmente vinculado aos movimentos da escola e dos processos educacionais em seu contexto histórico, entretanto esse impacto da escola sobre a organização dos cursos de Pedagogia parece-nos menos intensa.

Consideremos, porém, que mesmo neste espaço pedagógico, os eventos profissionais se diferenciam e exigem saberes pedagógicos diversos e que implicam capacidades de lidar, inclusive, com a imprevisibilidade de modo específico no campo de profissionalidade de cada conjuntura de atuação do pedagogo em diferentes atividades de docência, planejamento, coordenação, administração, orientação ou supervisão do ensino e na escola.

Embora haja relativa especificidade no estatuto das diferentes profissionalidades do pedagogo, $\mathrm{o}$ fato de se destinarem ao exercício profissional, principalmente na escola pública, e de perseguirem 0 aperfeiçoamento do pensamento e do fazer pedagógico, imputa-Ihes o desafio de garantir a unidade do ser pedagogo em suas múltiplas inserções, a 
considerar: seus saberes técnicos, estéticos, políticos e éticos acerca da profissão de maneira a contribuir para o desenvolvimento da identidade profissional dos gestores escolares (RIOS, 2001).

A maneira de pensar e organizar a formação do pedagogo que defendemos corrobora a perspectiva da integralidade dos saberes para atuar em inserções profissionais nos campos escolares, ou não, que exigem o trabalho pedagógico, implicando numa competência de olhar, analisar e atuar sobre a totalidade do fenômeno pedagógico, o que nos colocaria diante da necessidade de transpor a "formação especializada" apenas por aglutinação de conhecimentos segmentados ou fragmentados, que não correspondem às exigências do trabalho educativo ou a complexidade escolar.

Esta forma de entender o trabalho dos gestores escolares, assim como seu significado na estrutura educacional se assenta numa concepção mais dialética e dialógica acerca do papel da escola, do pedagogo e das aprendizagens, o que, conforme Pinto (2006), tem relação com a formação universitária inicial, mas que sofrem os impactos do contexto do trabalho o que demandaria pensarmos, que formação inicial é esta:

Em que pese a deficiência de estruturação do curso de formação inicial de um
profissional do ensino, o contexto institucional em que ele atuará, muitas vezes,
é o que mais determina sua ação pedagógica. Um pedagogo formado em um
curso de quatro anos, com especialização no último ano, se for trabalhar em
uma escola com um Projeto Político Pedagógico consolidado numa gestão
democrático-participativa, atuará mais de acordo com a proposta pedagógica
da escola do que em função dos princípios norteadores da habilitação cursada
em sua formação inicial (PINTO, 2006, p. 105).

Postulamos o pedagogo como o profissional responsável e capaz de articular o fortalecimento pedagógico da escola como lugar de aprendizagem, mas também constituída por aspectos legais, administrativos, organizacionais, humanos e financeiros, que revelam a existência de atividades relacionadas ao planejamento, administração, assessoramento, supervisão ou orientação educacional - devendo, porém, estarem a serviço do desenvolvimento da institucional. 
Em considerando este conjunto de aspectos sob os quais deve atuar, entendemos que ao pedagogo cabe investigar e compreender a relação entre a profissão docente em diferentes inserções e o mundo do trabalho educativo que contempla uma cultura específica em relação a seus ritos, complexidades e desafios.

Se a aprendizagem e a formação devem ser o centro de sua profissionalidade, estas precisam assentar-se na dialogicidade das mediações culturais, sociais e antropológicas que fazem parte do contexto da escola ou mesmo de espaços não escolares.

Com efeito, para a efetiva mediação e tarefa formativa, é vital que consideremos o patrimônio acumulado pelos diferentes profissionais de coordenação do trabalho pedagógico, sejam estes essencialmente de planejamento, de direção, de supervisão ou inspeção, da coordenação ou da orientação educacional, com o dever de ofício de estarem a serviço do serviço da escola.

Não se pode supor que qualquer formação seja capaz de constituir inicialmente um profissional com habilidades e competências qualitativamente estruturadas para que atue de maneira eficaz, de modo que os pedagogos subsidiem os docentes e os profissionais que desenvolvem a prática pedagógica na escola e não necessariamente o inverso, preterindo o caráter visionário que deve prescrever a atividade do gestor escolar.

Franco (2008) destaca que atribuir o devido valor à Pedagogia, e consequentemente ao pedagogo, é uma das alternativas para se reconhecer a importância de um trabalho científica e epistemologicamente fundamentado para que possa provocar mudanças no complexo mundo educacional, o que se coloca também como uma das formas possíveis para a valorização do magistério. A pesquisadora ainda afirma que,

$\mathrm{Na}$ tentativa de reinterpretar as necessidades formativas do pedagogo, considero importante inverter a epistemologia que tem fundamentado a maioria dos discursos sobre a Pedagogia: acredito na Pedagogia como elemento de identidade à prática docente e não na prática docente como elemento identificador da identidade da Pedagogia. Considero que, pelo que expus, pude deixar fundamentado que a docência, uma das modalidades da práxis 
educativa, deve se organizar pela Pedagogia e não seria correto afirmar que é a Pedagogia que deveria se organizar pela docência. Assim, faço, nessas reflexões iniciais, um breve comentário sobre a questão da base de formação dos profissionais da educação (FRANCO, 2008, p.114).

Compartilhando da idéia de Pedagogia como ciência, defendida pela autora e por Pinto (2006), acreditamos que a atuação do pedagogo na escola é tarefa eminentemente coletiva, isto é, exige que os profissionais do magistério e, neste caso, os "especialistas de educação", então gestores, estejam articulados em favor do projeto da escola, o que não representa uma condição fácil de ser conquistada, pois depende, inclusive, da concepção de educação que estes profissionais trazem de sua formação, de seus saberes profissionais, e das experiências educacionais.

Compreender que as tarefas do pedagogo que atua no campo da gestão são eminentemente pedagógicas corresponde à posição de Brzezinski (2002) a respeito do professor como detentor de saberes que transbordam a sala de aula, possibilitando a compreensão da totalidade da ação educativa.

Para a pesquisadora, esta capacidade precisa ser fomentada em sua formação pautada no propósito da profissionalização, assim, não prescinde da consciência acerca da integralidade epistemológica e da profissionalidade pedagógica e, neste caso, gestão vai além de organização administrativa.

Neste sentido, à medida que julgamos que embora a Pedagogia enquanto ciência da educação seja essencialmente o fundamento de investigação do fazer pedagógico, é no exercício da atividade educativa, não apenas docentes, que são gerados os conflitos e confrontos sobre os quais se lançará a luz da investigação.

Por tal entendimento, nos parece que o fazer pedagógico, como processo de aprendizagem, carece de mediações que devem ser um aspecto significativo da formação do pedagogo, inclusive para a realização de investigações sobre a prática, tanto docente como da gestão escolar. 
Ao redefinir a relevância da formação do pedagogo como grande desafio para a educação e, portanto, à organização dos cursos de Pedagogia para que a condição de complexidade profissional seja contemplada, e adquira solidez e visão de totalidade, Franco (2008), ainda que distinguindo o foco da Pedagogia na ciência e não exatamente no fazer docente, admite que o processo de profissionalização presume a atuação do pedagogo a partir da práxis educativa.

Concordamos plenamente com a admissão de não se tratar apenas de um processo de consecução de certificados de habilitação, mas da constituição de uma identidade pedagógica própria para um profissional que atuará possivelmente em diferentes eixos, sejam eles a docência, a administração ou direção, a coordenação pedagógica, a supervisão ou a orientação educacional:

\begin{abstract}
No processo de sua formação, o pedagogo deve construir profunda intimidade com as questões da docência, do ensino, mas será inconcebível subsumir a formação de pedagogos ao exclusivo exercício docente. A tarefa pressuposta ao pedagogo, ou seja, a de ser um pesquisador crítico da práxis educativa requer uma sofisticada formação; assim como a tarefa de formação de um professor crítico-reflexivo também a exige. Mas os focos da formação são diferentes: ao pedagogo, são os processos constituintes e intervenientes na práxis educativa; ao professor, a ênfase está nos processos dialógicos e dialéticos da relação aluno e conhecimento, quer na construção, quer na apropriação desse processo. Focos próximos e complementares, mas diferentes e que requerem olhares, metodologias, procedimentos e preparos diferenciados (FRANCO, 2008, p. 124).
\end{abstract}

Nesse mesmo sentido, defendemos que o curso de Pedagogia exige a busca permanente de sua identidade e do reconhecimento de sua especificidade, como alternativa para romper com a dicotomia entre teoria e prática, dirimir seus conflitos idiossincráticos, com a superação da ruptura entre o pedagógico docente e o pedagógico que se concretiza nas atividades dos pedagogos que atuam como suporte à docência, ao ensino, além do viés da pesquisa.

Procuramos destacar que o esperado da formação do pedagogo é um escopo de conteúdos e práticas que efetivamente contribuam para que o mesmo desenvolva competência profissional e, no caso desta pesquisa, mais pontualmente, competência para o exercício não apenas da docência, mas das 
atividades relacionadas aos processos educativos de gestão sobretudo na escola pública, inclusive considerando seu caráter público, que é essencialmente político.

O conceito de competência ao qual nos referimos é o que transcende o domínio de destrezas, de capacidades isoladas de operação ou mesmo de eficiência para lidar específica e isoladamente num aspecto de organização dos processos educativos. Adotamos competência como um conjunto "orquestrado" de habilidades e capacidades sobre o fazer de modo que a atuação tenha mais qualidade e relevância para o movimento de melhoria dos processos, portanto não é atributo meramente técnico, ou seja, é mediada pela ética e pela consciência política, como já postulamos.

Libâneo (1985) aponta que o trabalho do pedagogo é por natureza político, pois requer que a articulação do "saber, o saber ser, e do saber fazer", que organizados na forma de um saber crítico permite que os profissionais superem a ilusão da crítica sobre os processos educativos e o fazer pedagógico crítico.

Neste caso, há de se observar que este "fazer" não se refere a práticas espontâneas, ou simplesmente resultantes das incontingências cotidianas, mas circunstanciadas do ponto de vista teórico-científico e contextualizadas do ponto de vista da complexa realidade educacional e das demandas das escolas, uma forma de romper com a racionalidade teórica no fazer pedagógico

Então, o que nos perguntamos é qual o lugar que se tem destinado à formação de pedagogos de modo que a partir de sua profissionalização possam contribuir e atuar na escola, na perspectiva do seu desenvolvimento institucional (Day, 2001). É justamente esta concepção de trabalho que elegemos como fundamento para análise dos cursos de Pedagogia no que se refere às propostas voltadas para a formação de um pedagogo que além da docência e da investigação educativa, que atuará em funções de gestão na escola.

Investigar como os cursos de Pedagogia tratam e abordam a formação dos demais profissionais do magistério (artigo 64 da Lei 9394/96) é uma 
tentativa de encarar, como propõe Demo (2005), os desafios postos à Pedagogia: a duração do curso; sua ambientação epistemológica; a estrutura de uma aprendizagem significativa para os pedagogos; reorientação curricular dos cursos, inclusive do ponto de vista metodológico; superação da ambigüidade histórica da Pedagogia, para dar conta da formação permanente ou continuada dos diferentes atores da educação.

Daqui em diante, apresentaremos algumas considerações preliminares sobre o andamento dos cursos de Pedagogia e sua organização, a partir do que a Resolução CNE CP 01/06 tem proposto com relação à formação dos profissionais da educação que atuarão nas atividades de gestão escolar, conforme artigo 14 da mesma resolução, para que possamos apontar alguns indícios que fundamentarão as conclusões que pretendemos alcançar nesta pesquisa.

Orientaremo-nos pelo pressuposto de que a forma de organização dos cursos e suas características indicam a concepção de gestores escolares que será priorizada durante o processo formativo dos pedagogos, nos cursos de Pedagogia, principalmente porque é no início deste processo de formação que os egressos terão acesso a um conjunto de saberes teóricos, práticos e científicos, acerca de sua profissão e de seu campo profissional.

Embora as matrizes curriculares como referência dos cursos representem ainda que parcialmente o currículo integral dos mesmos, abordar estes documentos nos permite analisar alguns aspectos sobre os princípios e finalidades, as propostas e a formação dos profissionais do magistério, abrangidos pelo artigo 64 da Lei 9394/96.

Será a partir deste conjunto de evidências iniciais que vamos problematizar as propostas contidas nos cursos de Pedagogia para os gestores dos processos escolares e o que defendemos como atuação em atividades de gestão numa perspectiva de desenvolvimento institucional e profissional. 


\subsection{Aspectos preliminares para análise dos cursos de Pedagogia da pesquisa}

Traremos algumas análises do conjunto de dados que se consolidarão como o corpus desta pesquisa, tendo como finalidade abordar dois aspectos fundamentais: o primeiro diz respeito ao estudo da constituição dos cursos de Pedagogia, no que se refere às possibilidades apresentadas para a formação dos profissionais do magistério para as atividades de coordenação, planejamento, administração, supervisão e orientação educacional; e o segundo será direcionado à investigação das contribuições possíveis dos cursos à formação destes profissionais, à construção da identidade dos gestores e ao desenvolvimento de sua profissionalidade na perspectiva do desenvolvimento profissional e institucional.

Cabe-nos salientar que compõem esta pesquisa os currículos de cursos de Pedagogia (matrizes), que estão distribuídos por todo o território nacional, e todos com sua organização a partir da legislação vigente, que se refere às Diretrizes Nacionais para o Curso de Pedagogia, nos termos da Resolução CNE CP 01/06, decorrente dos Pareceres CNE 05/05 e 03/06, que trataram, em especial o último parecer, da formação dos profissionais do magistério que desenvolveriam atividades que não exclusivamente docentes.

Iniciaremos a análise do corpus pelos dados que caracterizam a origem e a vinculação institucional dos cursos que compõem o corpus desta pesquisa, e, portanto, servirão de base para os estudos comparativos.

Selecionamos uma amostra diversificada de instituições em dois grupos de natureza institucional, sendo: 33 públicas e 97 privadas $^{34}$. Dentre os 33 cursos do setor público, $69 \%$ deles são oferecidos por universidades federais e $31 \%$ por universidades estaduais. Com relação aos cursos oferecidos por

\footnotetext{
${ }^{34}$ Antecipamos que no grupo das Instituições de Ensino Superior privadas estão incluídas apenas seis cursos de instituições comunitárias e confessionais, motivo pelo qual julgamos desnecessário a criação de um terceiro grupo de análise, embora tais cursos tenham características qualitativas mais relevantes, e portanto apresentam alguma diferenciação nos seus currículos e propostas de formação dos pedagogos, embora já sofram os efeitos que também incidem sobre as demais instituições de natureza privada de propriedade particular.
} 
instituições privadas, num total de 97 cursos, 63\% são organizados em faculdades isoladas, $28 \%$ por universidades e $9 \%$ vinculados a centros universitários:
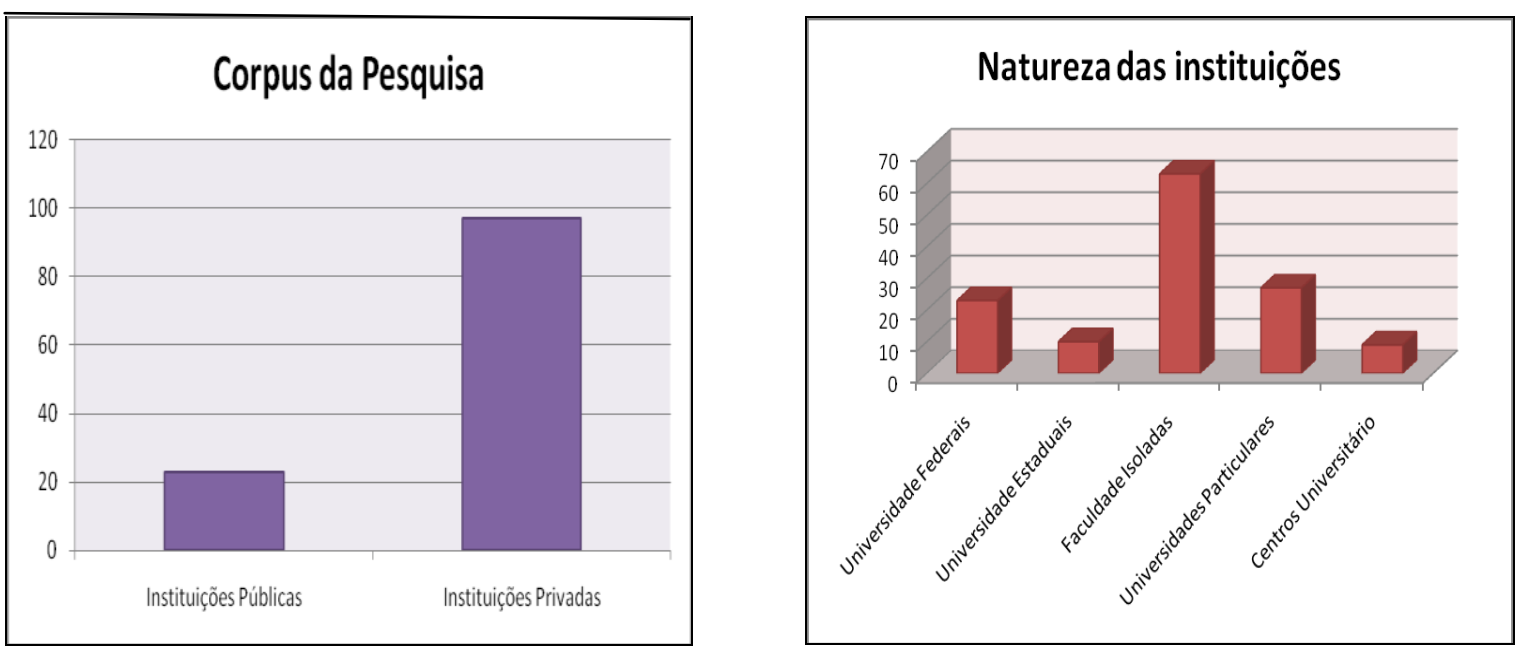

Este conjunto de cursos possibilita identificarmos a tendência de diversidade que existe entre a formatação dos cursos que são oferecidos pelas instituições públicas e privadas, com especificidades curriculares, que se apresentam como reincidentes em cada um dos segmentos de origem administrativa, inclusive em relação aos aspectos que são comuns entre os diferentes segmentos, nas propostas que se referem à formação dos pedagogos que também poderão atuar como gestores escolares.

Ademais, há determinados aspectos relacionados ao quadro de pessoal, do tempo curricular, de disponibilidade de alternativas metodológicas de formação para os alunos que se diferem em unidades públicas e privadas, dada inclusive a estrutura administrativa e organizacional que caracterizam estas instituições.

Outro aspecto ligado à diferenciação institucional, que é apresentado pelos cursos analisados nesta pesquisa, é a variação das formas de organização dos currículos que são oferecidos por instituições de diferentes abrangências, ou seja, cursos de universidades, faculdades e centros 
universitários, que possuem certas peculiaridades em sua proposta de desenvolvimento do ensino, da extensão e da pesquisa (quando há), como condições de apoio e melhoria da formação profissional dos pedagogos, até mesmo, pela eventual existência de outros cursos de licenciatura que poderiam estabelecer diálogos formativos ou de intersecções curriculares em relação à Pedagogia.

Em relação à esta organização curricular, nos dedicaremos à identificação dos conteúdos de formação dos gestores, seja nas disciplinas regulares nas eventuais possibilidades de diversificação de disciplinas, em estágios, ou em atividades complementares.

No que se refere à abrangência geográfica dos cursos, que foram coletados para compor o corpus desta pesquisa, apresentaremos cursos oferecidos em todo o território nacional, de modo que os aspectos demográficos possam compor a identificação de tendência, uma vez que já presumir-se-ia que áreas metropolitanas da região centro-sul do país concentrariam naturalmente maior oferta, o que poderia preterir aspectos presentes em cursos de áreas mais ao norte do país.

Nota-se nesta análise global do conjunto de cursos de Pedagogia, que de fato tal abrangência é pertinente, uma vez que cursos de regiões como norte e nordeste propõem disciplinas como "contador de histórias" " pedagogia dos povos indígenas", "processo educacional no meio rural", "educação indígena"; enquanto cursos da região sudeste, por exemplo, apresentam algumas disciplinas como "pedagogo na empresa", ou "pedagogia e empreendedorismo", "ética e marketing de relacionamento", "educação corporativa", "empreendedorismo e ensino".

Esta diferenciação também implica, de modo geral, nas disciplinas destinadas à formação dos gestores escolares, como trataremos mais adiante, mas que brevemente acenamos. Enquanto cursos mais isolados geograficamente ainda apresentam predominantemente disciplinas mais genéricas como "gestão escolar", nas regiões mais economicamente centralizadas identificam-se disciplinas como "gestão de resultados", "gestão 
do currículo", "gestão de políticas públicas", embora esta diferenciação, isoladamente, não possa ser tomada como indicador de melhor qualidade de formação do pedagogo, mas como um aspecto que difere esta formação.

Os dados gerais de desenvolvimento da educação básica nas escolas públicas do Brasil, no caso o IDEB $2011^{35}$, indicam que a grande maioria dos estados das regiões sul e sudeste tem resultados mais elevados do que estados da região norte e nordeste. Por outro lado, os dados demonstrados pelo IDESP, que se refere à avaliação do rendimento escolar das escolas estaduais do Estado de São Paulo, indicam que tais resultados não dependam apenas, e exclusivamente, do que fazem e como trabalham os profissionais nas escolas públicas.

Poderíamos inferir que, do ponto de vista das propostas e ações de formação de professores, e, por analogia, aos profissionais do magistério que atuam em atividades de suporte pedagógico (coordenação, assessoramento, planejamento, administração, supervisão ou orientação educacional) existiriam especificidades nos cursos oferecidos nestas regiões, o que Ihes possibilitaria resultados diferenciados quando da atuação nas escolas e nos sistemas de educação. Inclusive deve-se observar o excesso de indicadores de avaliação que têm determinado o modo de organização das escolas públicas no país.

\footnotetext{
${ }^{35}$ Os resultados do IDEB (Índice de Desenvolvimento da Educação Básica) no Brasil indicam avanço durante o período 2005 - 2007 - 2009 - 2011, nos diferentes níveis da educação básica: anos iniciais do $\operatorname{EF}(3,6-4,0-4,4-4,7)$; anos finais do $\operatorname{EF}(3,2-3,5-3,7-3,9)$; ensino médio $(3,1-3,2-3,4-3,4)$, o que sugere que políticas públicas educacionais e a forma de gestão, também na escola, que tem sido destinada a elas tem gerado impacto no que tange aos resultados de desempenho dos alunos. Entretanto, quando a exemplo, lidamos com o IDESP (Índice de Desenvolvimento da Educação em São Paulo), tomando por base a série histórica 2007 a 2013, notamos que mesmo com a implantação de uma série de medidas que buscaram "reformar o sistema paulista", ainda há oscilações, e situações de queda nos índices que demonstram o desempenho, e pretensamente a aprendizagem dos alunos. Os resultados podem nos induzir a conclusão de que algo na gestão escolar, em seus diferentes aspectos, tem se diferenciado nas unidades que possuem os anos iniciais do EF $(3,23-3,25-3,86-$ $3,96-4,24-4,28-4,42$ ), ao obterem resultados progressivos e substanciais, diferentemente dos anos finais do EF $(2,54-2,60-2,84-2,52-2,57-2,50-2,50)$, e no final do ensino médio $(1,41-1,95-1,98-1,81-1,78-1,91-1,83)$. A diferença a que nos referimos não se restringe apenas a profissionalização dos pedagogos que atuam nesta atividade, mas também nas condições efetivas sob as quais se desenvolve a profissionalidade de diretores, professores coordenadores e supervisores de ensino.
} 
Entretanto, não se pretende desconsiderar outros aspectos relacionados às políticas públicas educacionais, ou mesmo, indicadores econômicos da região, nem tampouco, julgar que a regionalidade seja fator predominante no estabelecimento de padrões de qualidade dos cursos e da formação dos profissionais, mas fator que influencia as propostas dos cursos, sobretudo em razão do contexto da localização do curso.

Não obstante, a distribuição demográfica regional brasileira dos cursos analisados representam proporcionalmente as diferentes áreas do país, possibilitando uma amostragem de elementos curriculares comuns das diferentes regiões e, por outro lado, características que podem demonstrar alguma especificidade nas propostas de formação do pedagogo, no que se refere à estrutura dos cursos.

Destarte, das 130 matrizes curriculares de cursos que compõem esta pesquisa há a seguinte distribuição geográfica: 11\% (14 cursos) se localizam no norte do país, 15\% (19 cursos) são oferecidos nos estados da região nordeste, $10 \%$ (13 cursos) são ofertados na região centro-oeste, 17\% (28 cursos) se referem a estados do sul do país, e 47\% (61 cursos) estão instalados nos estados da região sudeste.

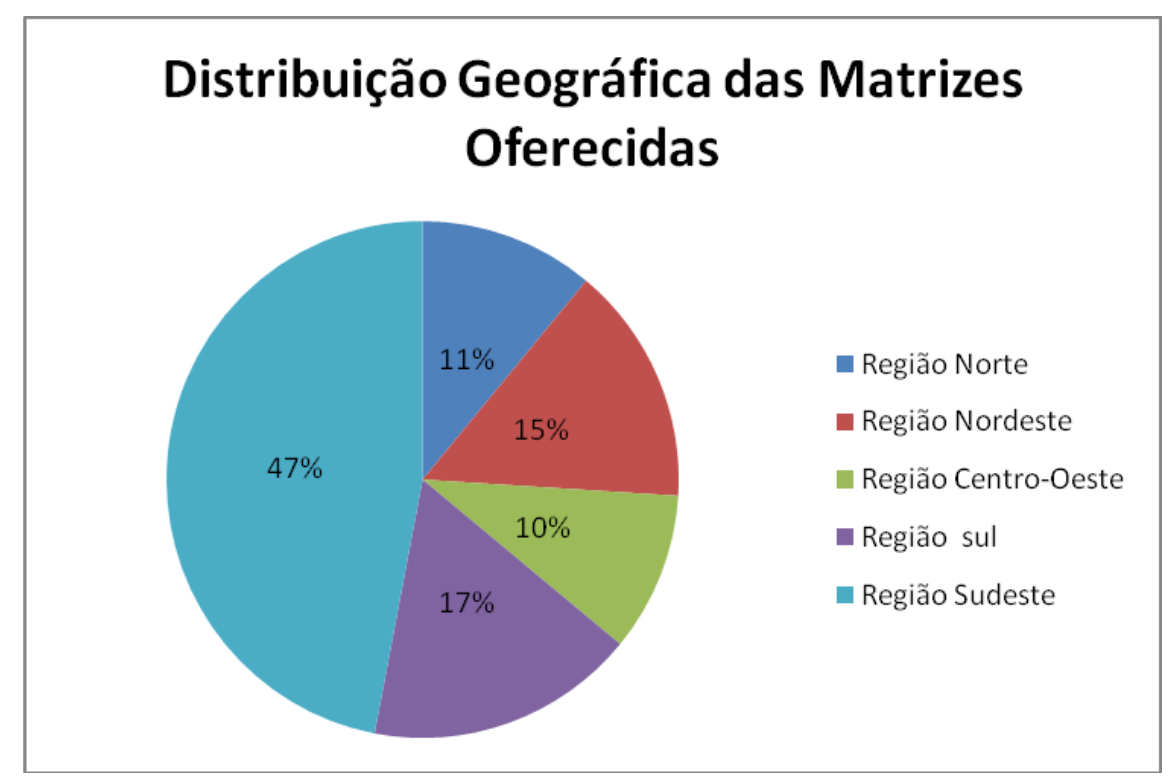


Com esta abrangência regional, também temos como intuito apresentar cursos que são desenvolvidos em regiões com diferentes níveis de escolaridade entre a população, e portanto, em áreas onde existam diferenciação na inserção local dos pedagogos que mesmo formados, a partir das diretrizes nacionais de cursos, recebem em seu processo de profissionalização inicial elementos específicos que têm relações com o enfoque educacional local.

Ainda sobre a abrangência geográfica da pesquisa, do total dos cursos analisados $59 \%$ pertencem a centros urbanos do país, enquanto que os demais $41 \%$ estão localizados em áreas consideradas como regiões de interior, o que possibilitou a identificação de marcas nas propostas de formação dos pedagogos, em virtude provavelmente, da influência das peculiaridades geográficas.

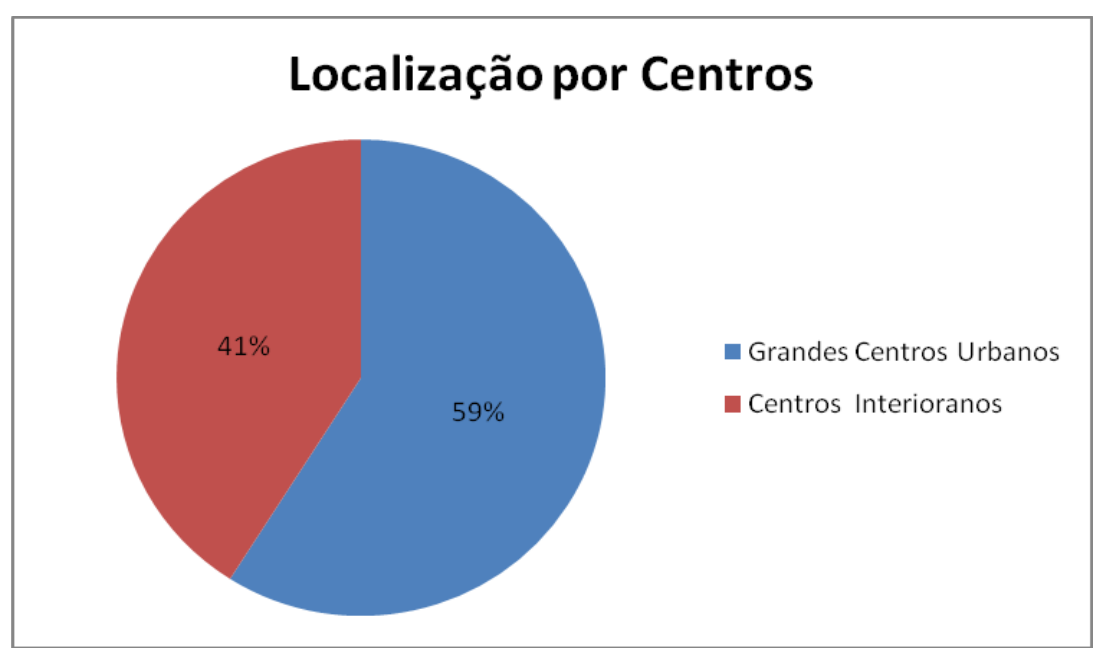

Um próximo aspecto que destacamos com relação às matrizes, é a proposta de modulação oferecida pelos cursos analisados, considerando sua organização em semestralidade ou anualidade. Neste caso, $93 \%$ dos cursos (121), que tomamos como elemento de análise, adotam organização semestral, enquanto que os demais, $7 \%$ (9), estão sob organização anual. 
Dentre todos os 130 cursos, apenas $24 \%$ deles, prevêem situações de matrículas optativas no interior dos semestres ou anos, ou seja, disciplinas cujos alunos podem fortalecer optativamente seu percurso formativo e, do total de cursos, apenas $8 \%$ oferecem a possibilidade de que os futuros pedagogos cursem disciplinas optativas ou eletivas, que poderiam promover a aproximação com saberes ou áreas do conhecimento que também enfoquem a atuação do pedagogo como gestor escolar ou educacional. Constituindo-se a situação demonstrada a seguir:

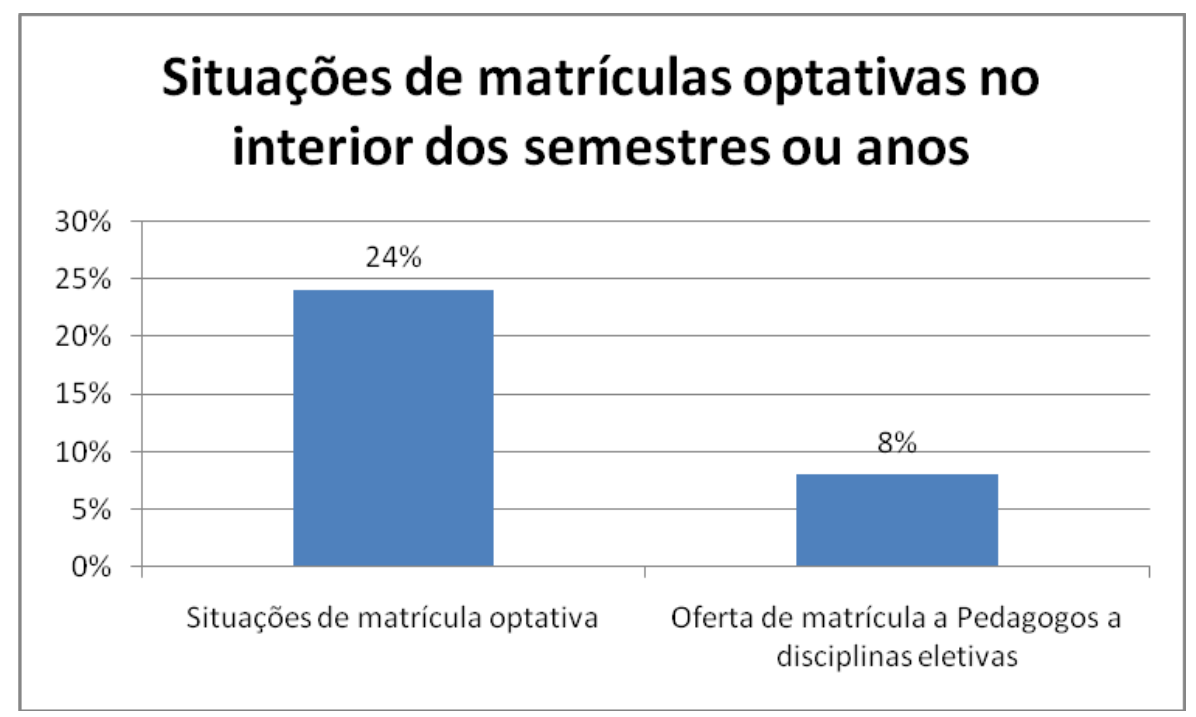

A possibilidade de diversificação curricular a qual nos referimos anteriormente aparece em $66 \%$ das instituições públicas de ensino superior, mas em apenas $15 \%$ das instituições privadas, o que infere uma aproximação de tratamento pedagógico no curso em determinados segmentos institucionais. 


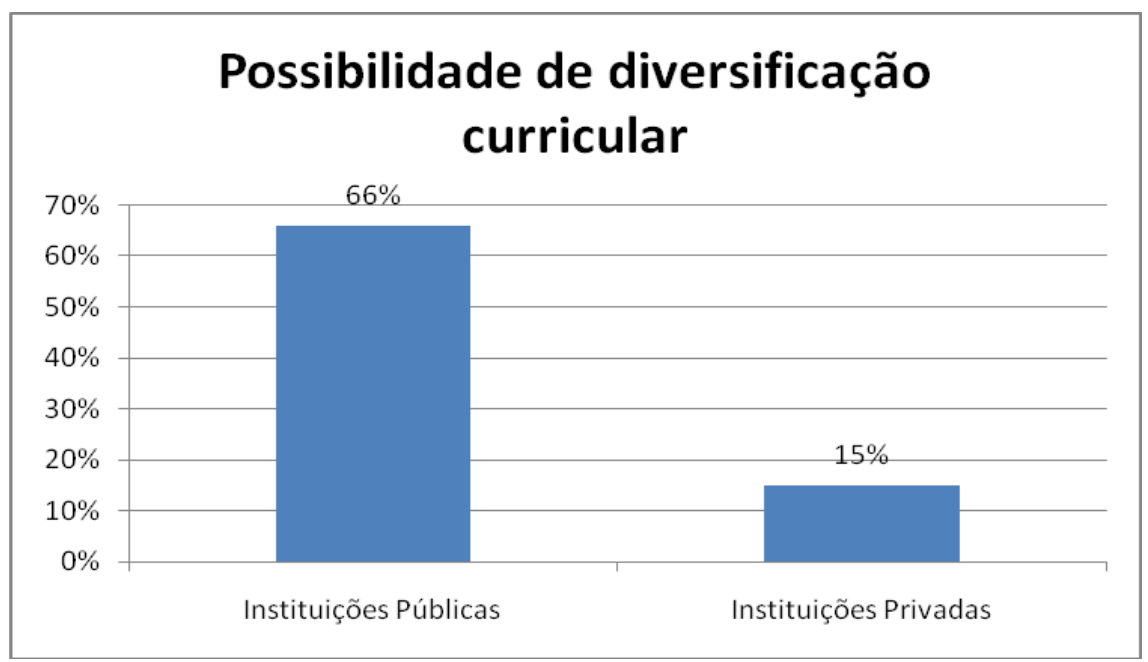

De modo geral, as possibilidades de flexibilização do itinerário formativo do pedagogo são extremamente herméticas, padronizadas e pré determinadas, não possibilitando a maioria dos egressos experiências no próprio curso o desenvolvimento de autonomia para aprofundamento de estudos ou a investigação diferenciada sob alguns aspectos que poderiam ser contemplados em situações opcionais ou eletivas, ainda que resguardada a necessidade da garantia de uma base geral de conhecimentos fundamentais e próprios da Pedagogia.

O cenário que vai se construindo por estas estruturas dos cursos mostra-se paradoxal em relação a como se forma o pedagogo, e o que se espera que construam como perfil profissional e, neste caso, sob o que atuarão como gestores escolares, um trabalho desenvolvido a partir de procedimentos e atitudes autônomas e com intelectualidade para a tomada de decisão, algo que a nosso ver já começa a ser pouco prestigiado nos cursos de formação destes profissionais, pelos indícios apresentados.

Como já apresentamos anteriormente, dos 130 cursos analisados, 121 são organizados em semestres, e os demais anualmente. Esta predominância de cursos semestrais demonstra situações que podem provocar conjunturas com reflexo ambígüo na formação. Se, por um lado, é possível que se destine ênfase a determinados aspectos da formação que se julga mais significativos em cada período de integralização; por outro, corre-se o risco de uma intensa 
fragmentação curricular $^{36}$ que se materializa pela pulverização de inúmeras disciplinas.

Corre-se ainda o risco de que a modulação semestral do curso sirva para repetir, de forma velada, a organização de blocos formativos que quando muito, se bem estruturados, destinam-se ao atendimento das diferentes possibilidades de atuação do pedagogo, ou seja, blocos para a formação pedagógica geral, docência na educação infantil, docência no ensino fundamental, conhecimentos sobre administração escolar ou supervisão educacional prioritariamente.

Este cenário implica uma formação por segmentos, que corre o risco de não se distanciar muito das ultrapassadas habilitações, caso esta proposta não seja bem articulada. Todavia, esta cautela também deve existir em cursos anuais que não se eximem de elegerem focos de destaque na formação e, neste caso, preterir determinados saberes que poderiam ser construídos por um período mais longo.

Ainda tratando da situação de organização estrutural dos cursos objetos desta pesquisa, constatamos que aliado ao sistema de fluxo dos períodos do curso, como apresentaremos posteriormente, este implica em fragmentação de muitas disciplinas durante períodos consideravelmente curtos: 3 (três) anos ou 6 (seis) semestres, provocando efeito deletério sobre o currículo.

Como a edição das Diretrizes Curriculares para o curso de Pedagogia, por meio da Resolução CNE CP 01/06, o caput do seu artigo $7^{\circ}$ estabeleceu o mínimo de 3.200 horas para a integralização do curso, entretanto, ao referir-se às categorias de atividades, especificou 300 (trezentas) horas para estágio supervisionado e 100 (cem) horas para atividades teórico-práticas; as demais

\footnotetext{
${ }^{36}$ A propósito desta degradação do curricular no curso de Pedagogia, notamos que a finalidade do mesmo e o modo de organização do currículo são dois grandes problemas encontrados durante, e após a definição das Diretrizes Curriculares do Curso de Pedagogia. Não obstante a isto, a discussão e reflexão acerca do currículo, também no âmbito da formação do pedagogo se mostra como uma fragilidade, pelo que constatamos nas matrizes curriculares, fato que compromete a formação deste profissional, que tem como um dos maiores desafios, ser curriculista.
} 
horas, 2.800 (duas mil e oitocentas), seriam voltadas para as atividades formativas, como já demonstramos anteriormente neste capítulo.

A nosso ver, isto incorporou uma série de possibilidades de oferecimento de atividades que viriam a compor estas horas, o que embora valorizasse o projeto pedagógico das instituições, também viabilizou o "enxugamento" dos cursos, inclusive pelo fato da citada resolução se omitir do período exigido para a integralização, como cita o inciso I do mesmo artigo:

2.800 horas dedicadas às atividades formativas como assistência a aulas, realização de seminários, participação na realização de pesquisas, consultas a bibliotecas e centros de documentação, visitas a instituições educacionais e culturais, atividades práticas de diferente natureza, participação em grupos cooperativos de estudos (inciso I, artigo $7^{\circ}$ da Resolução CNE CP 01/06).

Corroborando esta afirmação, dos 130 cursos analisados, foram identificados 32 cursos (24\%) estruturados em até 3 anos ou 6 semestres; 9 cursos (7\%), estão organizados em 3 anos e meio, ou 7 semestres; enquanto que outros 82 cursos (63\%) são organizados em períodos até 4 anos ou 8 semestres, restando apenas $6 \%$ dos cursos (7) com propostas curriculares estendidas a mais de 4 anos ou 8 semestres ${ }^{37}$, também estes predominantemente oferecidos por instituições públicas. Tem havido uma combinação dramática: a redução progressiva do tempo do curso, com a inserção de um número cada vez maior de "atividades complementares", em

\footnotetext{
${ }^{37}$ Quando Ministro da Educação, Fernando Haddad aprovou, com a edição da Portaria Ministerial 818, de 18 de junho de 2010, o Instrumento de Avaliação para Reconhecimento dos Cursos de Licenciatura em Pedagogia, no âmbito do Sistema Nacional de Avaliação do Ensino Superior - SINAES, indicando como um dos requisitos mínimos para o curso o período de integralização de 4 (quatro) anos, ou 8 (oito) semestres, o que deve gerar impacto e redimensionamento nos cursos em vigência, embora ainda careça de regulamentações complementares. Este fato já havia ocorrido semelhantemente em 2006, quando o então Diretor do Departamento de Supervisão de Ensino Superior do Ministério da Educação, Mário Portugal Pederneiras, editou um Despacho com efeito de "recomendação", para que o curso de Pedagogia fosse integralizado em, no mínimo, quatro anos, ou oito semestres, já reconhecendo à época, certa compressão do tempo destinado à formação dos pedagogos.
} 
curso mais extensos, nas instituições privadas, que absorvem a maioria dos alunos do ensino superior.

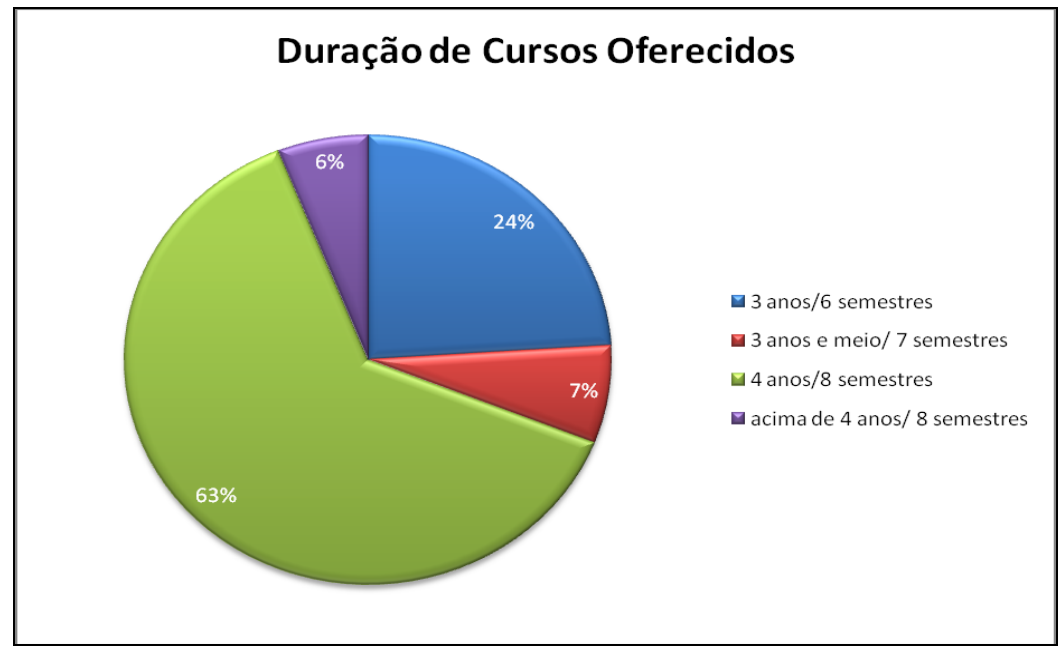

Em princípio, quando analisamos os dados de integralização dos cursos paira uma tranqüilidade pelo percentual de cursos com 4 anos, ou mais, entretanto esta é uma percepção apenas aparente, pois ao separarmos as instituições por sua natureza pública ou privada, constatamos que enquanto nas públicas nenhum curso é oferecido em tempo menor ao de 4 anos, nas privadas, que são responsáveis pela formação da maioria dos profissionais da Pedagogia, 43\% dos cursos já tinham menos de 4 anos, até 2010, com a tendência progressiva de expansão da condição para outras instituições privadas, como demonstramos, a seguir:

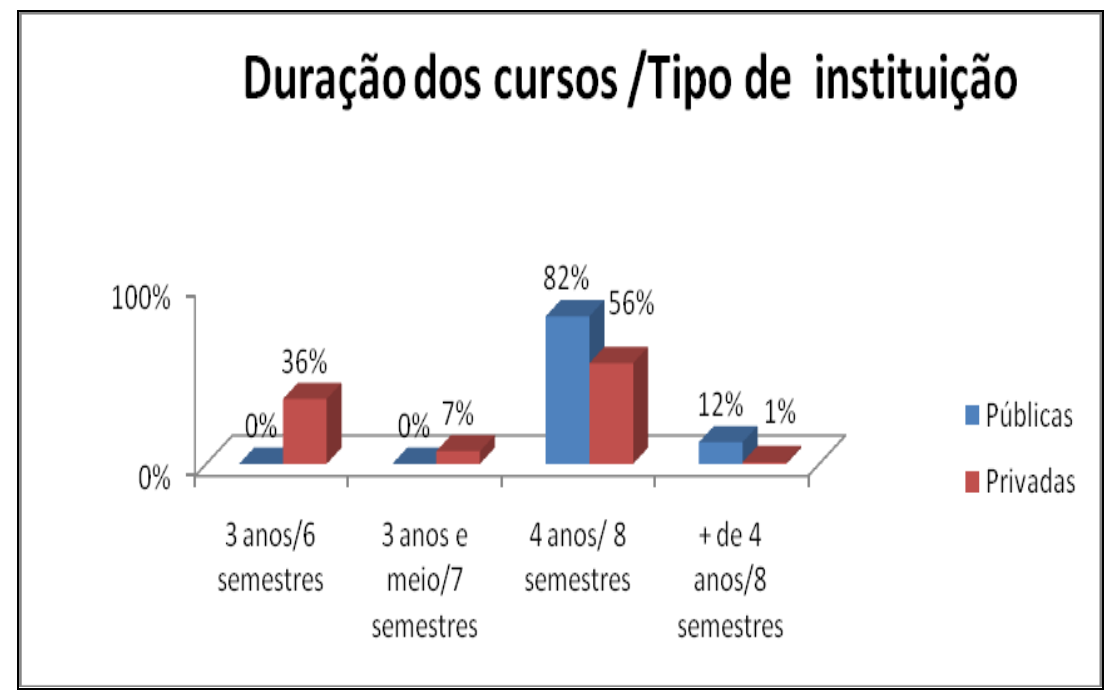


Presumimos que esta variação nas propostas de duração dos cursos para a formação do pedagogo, embora seja legal, exigiria atividades intensamente interdisciplinares e integradas, inclusive como alternativa de maximização do tempo, característica esta que não notamos na estrutura das matrizes, perceptivelmente convencionais, como será exposto na análise das disciplinas que constam destes currículos, caso contrário, a despeito das exigências, permaneceremos flagelando de modo fragmentário e superficialista de sistematizar a profissionalização daqueles que poderão atuar em diferentes ofícios no magistério.

Outro aspecto relevante diz respeito à estrutura dos cursos que analisaremos nesta pesquisa, nos dedicamos a uma coleta representativa de cursos da modalidade presencial, de modo a garantir um parâmetro organizativo aproximado de todos os objetos de análise; considerando-se que cursos desenvolvidos a distância preconizam outra organização metodológica, curricular e de carga horária prática em seu desenvolvimento.

Por se tratarem de cursos presenciais, possibilitou-nos coletar a situação em relação a carga horária semanal: $58 \%$ de cursos têm 20 horas de aulas semanais (76 cursos), enquanto cerca de 10\% destes (13 cursos), têm cerca de 16 horas de aulas presenciais na estrutura curricular. Somente $3 \%$ dos cursos, ou seja, 4 cursos, se organizam com carga horária de aula menor do que 16 horas aulas semanais.

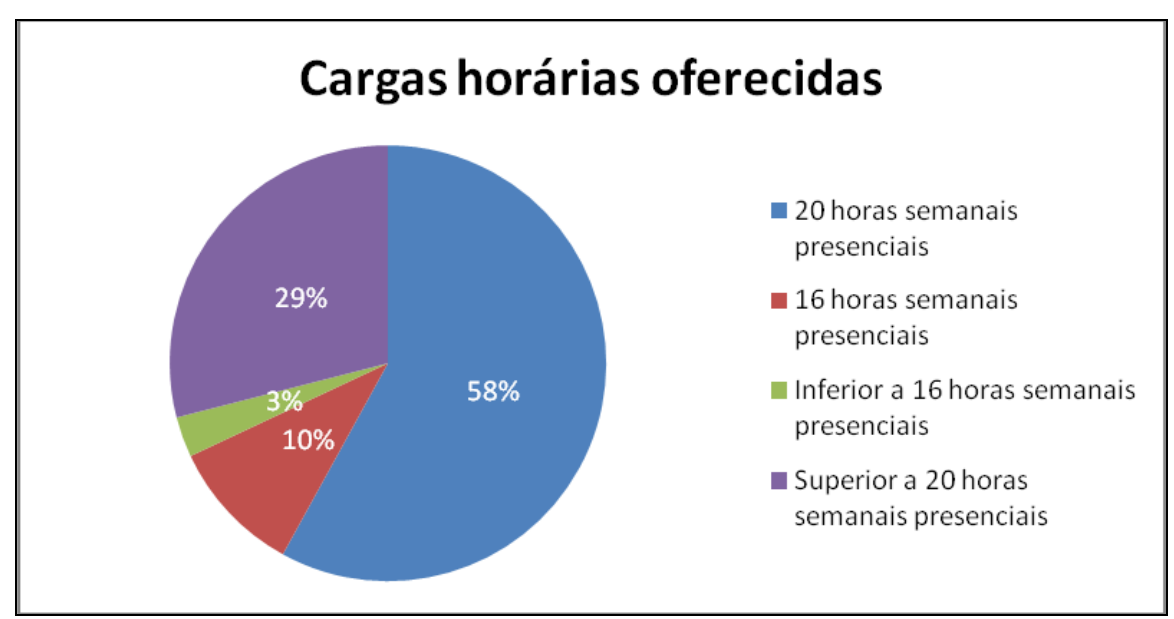


Esta variação de carga horária das aulas, entre a amostragem dos cursos com os quais trabalhamos, pode ser fator agravante da eficácia do cumprimento do que está previsto legalmente em relação aos vários campos de atuação do pedagogo. É presumível que quanto menos tempo se tem para formar aqueles que atuarão em tantos campos de atuação, mais crítica tornarse-á a condição formativa.

O fato de estarmos nos detendo ao estudo de um curso que, em tese, será base formativa dos muitos egressos, quando nos referirmos à formação universitária inicial, nos permite refletir sobre as possibilidades e limitações pedagógicas de ambientes virtuais, de atividades desenvolvidas mais independentemente pelos alunos, ou de propostas complementares extras.

A nosso ver, o ambiente acadêmico é aspecto fundamental na construção do perfil profissional, inclusive pelas incursões realizadas na relação professor e aluno, entre os alunos, e entre estes protagonistas e o projeto institucional em ação.

Esta nos parece uma das formas mais autênticas de experienciação do ambiente acadêmico universitário. Neste sentido, 91\% das instituições públicas propõem que os alunos estejam neste ambiente ao menos 20 horas semanais, enquanto que nas instituições privadas, $53 \%$ propõem o mesmo período de permanência, enquanto que ainda nestas $26 \%$ organizam suas atividades presenciais em cerca de 16 horas semanais, como apresentamos:

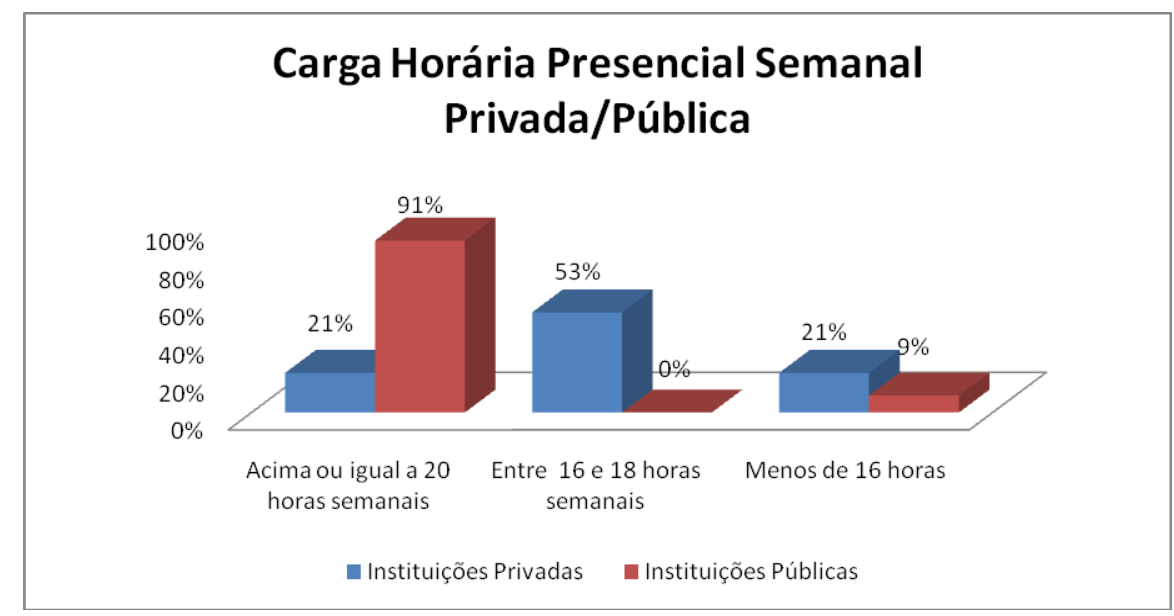


Tal conjuntura de disposição de tempo na relação professor - aluno, em aulas, que consideramos momento privilegiado de formação, dado o fato de ser um dos elementos prioritários da ação do pedagogo, agrava ainda mais a celeuma que ora se assenta sobre o curso de Pedagogia, e isto invalida a hipótese de que criar diferentes percursos de formação no interior do curso seja a resolução para esta situação imprecisa: formar um profissional que atue em cada vez mais ofícios educacionais, em cada vez menos tempo efetivo de formação inicial e com alternativas didático - metodológicas cronicamente mais obsoletas.

Além da variação da carga horária "de aulas", que constituem os cursos, esta poderia ser apenas um dos fatores de diferenciação e identidade do projeto pedagógico das propostas. Contudo, lidamos com o fato de encontrarmos uma variação considerável a respeito do que é denominado como "atividades complementares" nos cursos de Pedagogia.

É fato que "atividades complementares" e diversificadas podem e devem enriquecer a formação dos egressos, ampliando as alternativas de contato do aluno com as várias possibilidades formativas e do mundo externo à academia; entretanto, isto reduz significativamente o tempo de trabalho efetivo entre alunos e professores, uma vez que o próprio Parecer CNE CP 03/06 trata de forma genérica do que seriam tais atividades, como podemos verificar:

- atividades complementares envolvendo o planejamento e o desenvolvimento progressivo do Trabalho de Curso, atividades de monitoria, de iniciação científica e de extensão, diretamente orientadas por membro do corpo docente da instituição de educação superior decorrentes ou articuladas às disciplinas, áreas de conhecimentos, seminários, eventos científico-culturais, estudos curriculares, de modo a propiciar vivências em algumas modalidades e experiências, entre outras, e opcionalmente, a educação de pessoas com necessidades especiais, a educação do campo, a educação indígena, a educação em remanescentes de quilombos, em organizações não governamentais, escolares e não-escolares públicas e privadas (Parecer CNE CP 03/06).

Como reflexo desta indefinição sobre o que é disposto como atividades complementares à formação do pedagogo, ainda que esta seja salutar à referência das diferentes experiências educativas ou das modalidades 
oferecidas, constatamos 34 (trinta e quatro) ${ }^{38}$ nomenclaturas que, embora se diferenciem em títulos, remetem-se às atividades complementares, muitas delas presentes em um único curso, o que torna a atividade complementar quase que em "atividade fundamental" para a formação do pedagogo.

Para que possamos demonstrar a amplitude da presença destas "atividades complementares" nos cursos de formação do pedagogo, identificamos que dentre os 130 cursos analisados, 36\% (47 cursos) propõem até 200 horas de atividades complementares, 27\% (35 cursos) apresentam mais de 300 horas destinadas a estas atividades, enquanto que $7 \%$ (9 cursos) deste conjunto destinam mais de 500 horas do total da carga horária do curso para esta modalidade de atividades, todas de natureza privada, como segue:

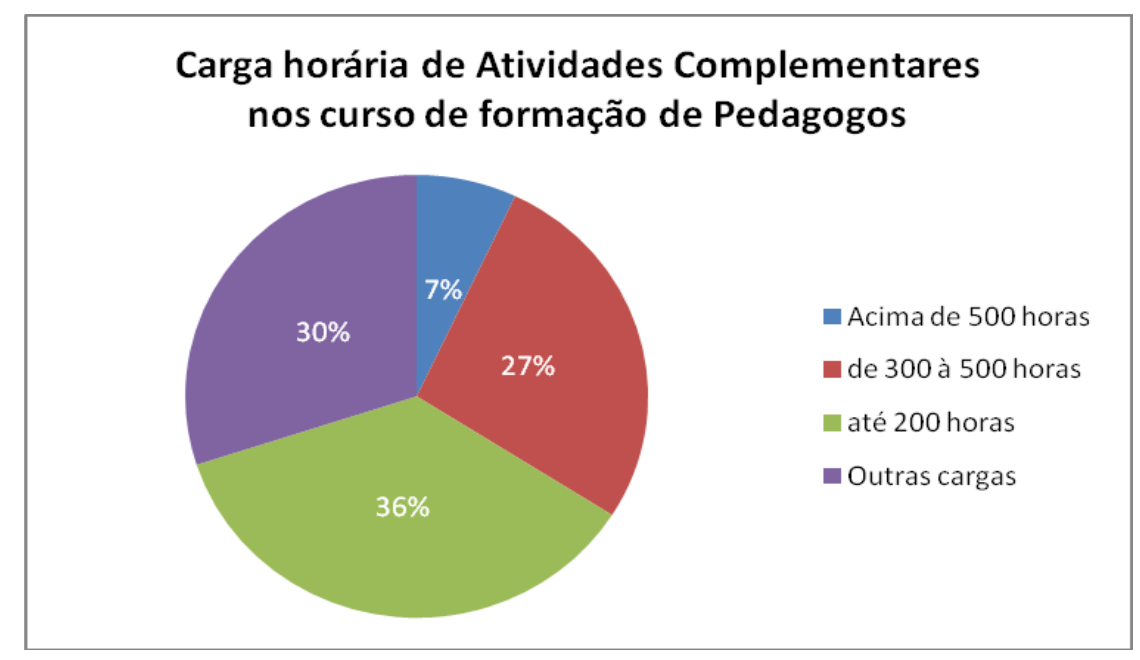

Enquanto $88 \%$ das públicas não sugerem mais de 300 horas de atividades complementares, nas instituições privadas $64 \%$ superam este parâmetro de horas para esta modalidade formativa. Ressalva-se ainda que, para o levantamento destas horas, não incluímos as que se destinam às atividades de estágio supervisionado, obrigatoriamente organizadas em, no

\footnotetext{
${ }^{38}$ Dentre as nomenclaturas a que fizemos menção citamos: estudos independentes, atividades de aprofundamento, atividades científicos culturais, atividades complementares, núcleo integrador, pesquisa e prática em educação, atividades práticas, projeto integrador, estudos integradores, prática educativa, seminário socializador, núcleo de aprofundamento e diversificação de estudos, projeto de pesquisa interdisciplinar, pesquisa e prática em educação, atividades teórico-práticas de aprofundamento, seminários integradores, dentre outros.
} 
mínimo, 300 horas durante a formação, como demonstramos no gráfico a seguir:

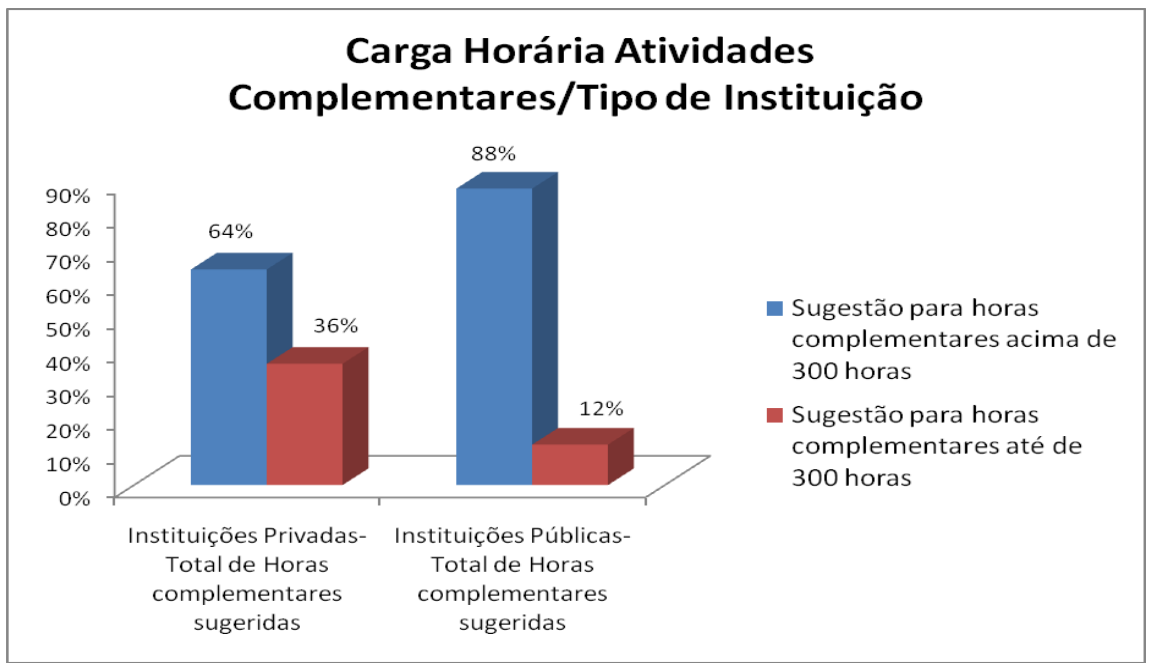

Também não identificamos nas matrizes curriculares referências claras e explícitas que possam indicar propostas de atividades complementares mais intensamente voltadas à formação dos pedagogos que atuarão em atividades de planejamento, coordenação, assessoramento, supervisão, administração ou orientação educacional, o que demonstra a expressão da prioridade legal em formar os docentes, mas desprestigia a indicação do artigo 14 da Resolução CNE CP 01/06, em garantir também a formação para outros ofícios presentes na esfera educacional.

Quando tratamos do quesito estágio supervisionado obrigatório do curso de Pedagogia, encontramos uma realidade semelhante a que apresentamos, ainda que preliminarmente, sobre o oferecimento de disciplinas na organização curricular do curso.

Seguindo a determinação legal, $69 \%$ dos cursos propõem que os estágios sejam realizados no campo da docência e de atividades de gestão, todavia, as propostas de gestão estão concentradas nas atividades de administração; $14 \%$ dos cursos propõem estágio apenas no campo da docência, enquanto que $17 \%$ dos cursos exploram atividades de estágio tanto 
na docência, gestão, como em outros campos de atuação do pedagogo, demonstrando abaixo:

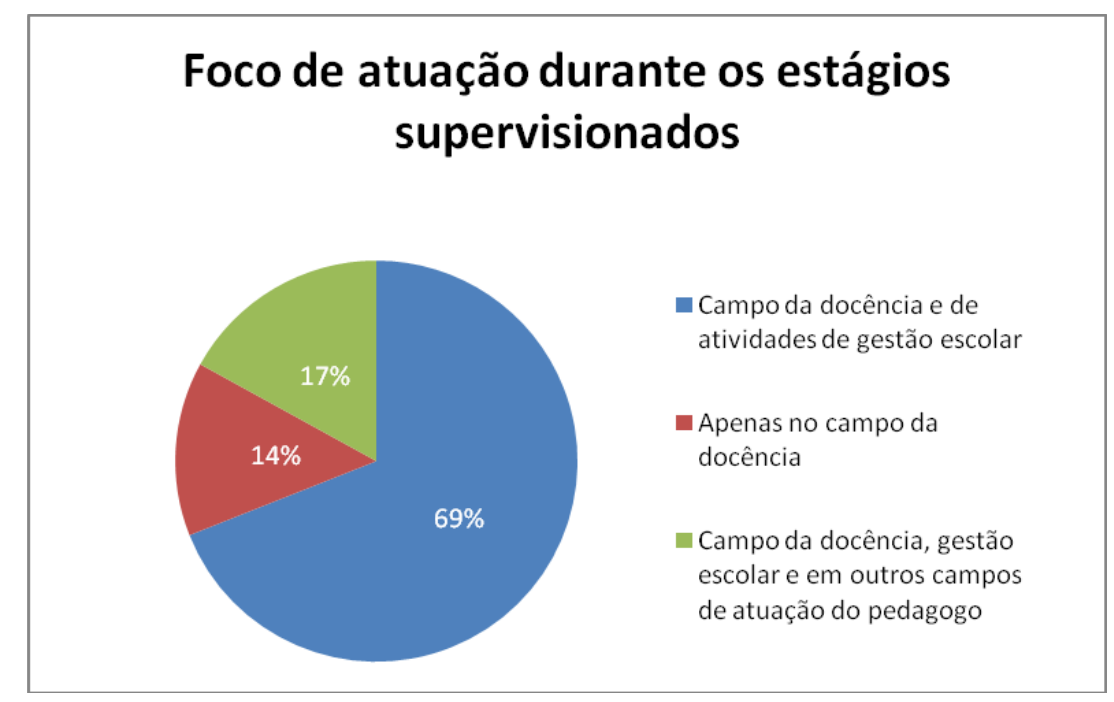

É interessante ressaltar que dentre todos os cursos que fizeram parte desta pesquisa $6 \%$ deles incluem em seu projeto pedagógico atividades de "prática profissional" distinta das atividades de estágios supervisionados obrigatórios e, neste caso, há oportunidade de reconhecimento de oportunidades autônomas de desenvolvimento e prática dos saberes vinculados à sua formação, já no campo de trabalho, sem necessariamente estar submetido à condição de supervisão obrigatória, ou em atividades diversas das escolares, principalmente.

Constata-se, portanto, que na maioria absoluta dos cursos, as atividades formativas estão vinculadas ao foco que se destina enfaticamente à formação do docente para o ensino fundamental, e mais abreviadamente para a educação infantil, ratificando o viés formativo priorizado pelos cursos neste processo de profissionalização inicial, permanecendo a gestão numa condição lacônica.

De maneira semelhante às disciplinas e os conteúdos que visam a formação dos gestores escolares, verificamos que estas atividadades de aproximação com o campo de trabalho (estágio, prática profissional, residência 
pedagógica, dentre outras) têm um lugar periférico nos cursos, e este afastamento também ressoa no depoimento dos egressos da Pedagogia, que já atuam nos ofícios de gestão escolar, principalmente quando afirmam que os estágios que realizaram, ou os estagiários que recebem, pouco se aproximam do que, de fato, acontece e é importante na organização da escola.

Com o propósito de continuarmos a estruturar esta discussão, apresentaremos de maneira mais sistematizada o conceito de gestão que tem estado em destaque no campo da educação e, como resposta, os referenciais teóricos que apontam o que concebemos como gestão para o meio educacional e escolar, numa perspectiva que tenha a ver com autonomia e reflexão crítica, e não gerenciamento, nos valendo, inclusive, de algumas evidências trazidas pelos cursos de formação de pedagogos, que também serão gestores escolares e educacionais. 


\section{CAPÍTULO II}

\section{Conceitos e fundamentos da gestão escolar e a profissionalidade dos gestores}

Neste capítulo, apresentaremos algumas evidências de que 0 movimento do curso de Pedagogia está relacionado às demandas que surgiram após a regulamentação para os profissionais do magistério responsáveis pela gestão escolar e da educação, em decorrência das novas formas de organização da estrutura escolar e do próprio sistema de ensino brasileiro, culminando na lei 9394/96 $6^{39}$.

Nas últimas cinco décadas, o sistema educacional brasileiro passou alterações significativas em sua estrutura, não apenas do ponto de vista legal, mas também no que se refere às formas de regulação das instituições, às metodologias de avaliação tanto da melhoria da aprendizagem como do desenvolvimento institucional, à premissa do atendimento da demanda escolar em regime de colaboratividade, além da destinação de responsabilidade própria para os sistemas de ensino, sobretudo os municipais, implicando numa mudança a respeito de como tal gestão passaria a ser feita.

No entanto, o fato de os sistemas de ensino expandirem gerou um movimento paradoxal: por um lado, as funções do magistério responsáveis pelas atividades que citamos anteriormente e que estão previstas no artigo 64 da Lei 9394/96, se multiplicaram e fizeram-se presentes tanto nas instâncias

\footnotetext{
${ }^{39}$ De modo geral, a LDB 4024/61 anunciava a obrigatoriedade do ensino, ainda que destinado para as séries iniciais, e permanecia com a organização de grupos escolares e ginásios, o que implicava numa certa organização do trabalho pedagógico e das exigências para a gestão dos estabelecimentos, ainda num modelo mais clássico e altamente seletista, do ponto de vista da demanda atendida. No caso da LDB 5692/71, houve uma aproximação com a abordagem tecnicista da escola, o que provocou por um lado a "escola juntada", que passou a atender o $1^{\circ}$ e $2^{\circ}$ graus, enquanto que o colegial tendia a habilitações profissionalizantes, o que não causou aprofundamento sobre a discussão do papel fundamental da escola na sociedade, dos professores diante do currículo escolar e da formação a eles destinada. Com o advento da LDB 9394/96, ficou evidenciada a preocupação com a formação dos profissionais da educação, como dispõem os artigos 61 a 67, uma vez que ainda surgiram inúmeros dilemas, a ênfase na articulação entre docência e gestão foi definida, assim como a importância da construção colaborativa do projeto de cada escola, a atuação dos gestores na gestão dos processos escolares e o destaque ao regime de colaboratividade.
} 
mais abrangentes, como nos sistemas estaduais, assim como os menores, ou seja, os sistemas municipais de educação.

Por outro, o ritmo acelerado de expansão e a própria discussão sobre a identidade dos pedagogos, em especial nos últimos 70 anos, impactou mais uma vez sobre as concepções acerca do que caberia a estes profissionais e como se daria a sua inserção nas atividades pedagógicas, muito devido à expansão dos sistemas municipais e estaduais de educação.

Mais objetivamente, buscou-se equacionar, a alarido que até então marcara a indefinida identidade do pedagogo no Brasil, e dos "especialistas de educação", quando o Parecer CFE 252/69, permaneceria tão vívido como as demais inquietações acerca de quem seria este pedagogo nos diversos ofícios do magistério, principalmente a partir da década de 1990.

Com efeito, este hibridismo em relação ao que seria ser profissional do magistério na gestão do trabalho teria como pano de fundo a discussão sobre qual seria o conceito de gestão escolar ou gestão educacional levado à prioridade para sistematização do trabalho educacional e escolar, considerando os modelos teóricos e práticos que orientam esta dimensão do trabalho em educação e o que se entende propriamente por gestão em educação nas escolas públicas, que estabelecemos como um dos objetos de análise da pesquisa, que devem assumir um papel formativo que vai além da vinculação estatal.

\subsection{A gestão do trabalho na escola: do conceito e das expectativas profissionais}

No capítulo anterior, trouxemos os dados históricos que demonstram como se desenvolveu o curso de Pedagogia no Brasil, mais precisamente a respeito do que se refere ao movimento de formação dos profissionais do magistério que se dedicariam às atividades de gestão escolar, a forma de planejamento, administração, supervisão, inspeção, coordenação ou orientação educacional. 
Destacamos que, embora as mudanças no curso de Pedagogia e nas propostas de formação dos especialistas, atualmente, gestores, ocorressem também em razão das mudanças sociais, assim como a educação enquanto aspecto da organização social, a celeuma existente na definição da identidade do pedagogo contribuiria, desde a década de 1940, para que se aprofundasse a deterioração da identidade do pedagogo, ora concebida como extremamente pontual e tecnicista, ora como intensamente generalista, sequer reconhecendo o foco pedagógico que deveria articular os diferentes campos de atuação deste profissional, principalmente na escola pública.

A formação dos profissionais do magistério para atividades de gestão chegaria a padecer de coerência no que se referiria à articulação necessária do pedagogo, em diferentes situações de atuação na escola. Haja vista que, neste local, a complexidade dos problemas não se manifesta de forma segmentada, apesar de não raramente serem tratados desta forma.

Por conseqüência desta ruptura entre o reconhecimento da essência pedagógica indispensável tanto para o trabalho docente, como no fazer dos demais pedagogos, durante muito tempo, idealizaram-se as atividades de docência como dissociadas ou inferiores à capacidade de se exercer tarefas de gestão do processo escolar, principalmente.

A fragilidade identitária do pedagogo no que diz respeito tanto a formação como à atuação, conseqüentemente, a sua profissionalidade na educação foi muito bem retratada por Silva (2006). De acordo com este autor, as décadas de 1970 a 1990 podem ser consideradas como períodos de intensa ebulição a respeito de quem seriam os profissionais pedagogos tanto no contexto de formação acadêmica, quanto no mundo do trabalho.

Já nos anos seguintes, não apenas se manteve a indefinição de como este processo se consolidaria, mas este se agravaria por exigir que os anseios dos educadores fossem alcançados com uma espécie de identidade decretada, como se assim ocorresse no plano da realidade, ou mesmo das idéias pedagógicas. 
É a promulgação da Lei de Diretrizes e Bases da Educação Nacional de dezembro de 1996 que demarca certa substituição emblemática do ponto de vista dos mecanismos legais e dos marcos teóricos sobre os profissionais responsáveis pelas atividades do magistério não dedicados exclusivamente à docência.

Não coincidentemente, é neste mesmo dispositivo legal que se subtrai, em seu artigo 64, a nomenclatura de "especialistas em educação" e se destaca tanto nos princípios educacionais, como no referencial de organização da escola, a expressão de "gestão democrática", como cita o inciso VIII do artigo $3^{\circ}$ "gestão democrática do ensino público, na forma desta Lei e da legislação dos sistemas de ensino", e em relação aos demais profissionais do magistério, como podemos conferir a seguir:

A formação de profissionais de educação para administração, planejamento,
inspeção, supervisão e orientação educacional para a educação básica, será
feita em cursos de graduação em Pedagogia ou em nível de pós-graduação, a
critério da instituição de ensino, garantida, nesta formação, a base comum
nacional (artigo 64, Lei 9394/96)

Do ponto de vista legal, a Lei de Diretrizes e Bases da Educação de 1996 apontou algo significativo no que se pode considerar como referência de formação e atividades de exercício dos profissionais responsáveis pela organização do processo educativo. Então, em meados da década de 1990, passou-se a considerá-los "profissionais do magistério" e não mais especialistas, que seriam fracionadamente habilitados em cursos seqüenciais, numa proposta quase supletiva.

Por outro viés, como aponta Saviani (2008), as Diretrizes Curriculares do Curso de Pedagogia, ao elegerem a prática docente como foco da formação do pedagogo, evidencia que a escola é o lócus privilegiado desta profissionalização. O que demonstra, ao mesmo tempo, um suposto afastamento dos egressos do curso em relação à escola, onde já estiveram durante muito tempo para apurarem sua capacidade de análise e, por outro lado, provoca-os a uma aproximação que seja contributiva para a identificação 
do sentido de seu trabalho pedagógico que precisa estar comprometido com a educação como direito cidadão.

Vale apontar que as $\mathrm{DCNP}^{40}$ apresentam uma diversidade significativa de competências para o trabalho a serem desenvolvidas no curso de Pedagogia, são previstas 16 competências gerais para os egressos ${ }^{41}$, tanto no plano da docência, como no das atividades de organização integrada da escola, além da investigação pedagógica.

Isto dado, é de se esperar que um pedagogo que seja formado em sua plenitude terá condições não apenas para a docência de qualidade, mas também para realizar atividades de planejamento, coordenação, administração e supervisão do trabalho educativo numa perspectiva mais integrada, o que nos faz pensar numa atuação pautada no princípio da gestão.

O termo gestão aplicado à educação foi utilizado, em Barcelona, na realização do $1^{\circ}$ Congresso Interuniversitário de Organização Escolar, em 1990. Tal emprego gerou deslizes, equívocos, contradições e desvios de finalidade e o mesmo continuaria após alguns anos, principalmente pelo fato de ter sido transplantado da área da administração para a educação. Podemos afirmar que este foi um fato determinante da investida do pensamento econômico e estratégico, de forma abrupta e impactante, na educação.

Segundo Glatter (1992), a ambigüidade que circundava o conceito de gestão se relacionava a idéia de controle dos mecanismos de trabalho, aproximando-se a proposta de manipulação, mas por outro lado, a proposta de organização das práticas de trabalho, a criação de formas mais sistematizadas para o alcance dos objetivos estabelecidos, mesmo no campo da educação.

\footnotetext{
${ }^{40}$ Aqui nos referimos as Diretrizes Curriculares Nacionais para o Curso de Pedagogia.

${ }^{41}$ Conforme previsto no artigo $5^{\circ}$ da Resolução CNE CP 01/06, publicada em 15 de maio deste ano, estabelecendo as Diretrizes Curriculares Nacionais para o Curso de Licenciatura em Pedagogia, deverão ser garantido este conjunto de competências aos egressos formados pelo curso (conforme anexo), de modo que tenham garantidas capacidades e habilidades para atuação docente, nas atividades de gestão do processo educacional, no trabalho pedagógico a ser desenvolvido em outros espaços formativos não escolares, e a prática da pesquisa e investigação do fenômeno pedagógico.
} 
Enfim, defendiam a lógica mais racionalista possível para um modelo de gestão voltado aos resultados mensuráveis, especialmente.

Para 0 autor ${ }^{42}$, contraditoriamente, neste primeiro congresso no qual ganhou vulto a expressão "gestão", o propósito era de superar a concepção racionalista e mecanicista de pensar o trabalho educativo, e apontar para um modo de orientação coletiva da atuação dos profissionais para as possibilidades de mudança e inovação em relação ao que se desenvolve profissionalmente.

Este movimento iniciou já na década de 1950, quando conceitos como o de cliente da educação, trabalho em equipe, liderança como função de intermediação do treinamento, além da redução da concepção de qualidade a aperfeiçoamento, atendimento em maior escala e ampliação das redes, apresentaram-se como elementos marcantes do discurso empresarial.

Desta apropriação com o conceito de gestão é que também se originou a temerária aproximação com a lógica de funcionamento das instituições escolares, que tem um papel social e político próprio, com o mundo empresarial, entretanto a lógica do mundo empresarial, que economicamente tem outras finalidades. Libâneo, Oliveira e Toschi (2005) contribuem significativamente para a compreensão desta distinção entre a organização da escola e a administração eficiente, em seus estudos. Para eles,

A administração eficiente e a tecnologia educacional são complementares ao enfoque sistêmico. A administração eficiente busca a racionalização do trabalho, bem como o controle do processo produtivo e o aumento da produtividade, ao passo que a tecnologia educacional se preocupa com o

\footnotetext{
${ }^{42}$ Ron Glatter (1992) defende o "conceito de gestão" relacionado à construção de praticas, mecanismos e instrumentos para a inovação, mudança e melhoria das formas de alcance dos objetivos educacionais, que devem estar vinculados a valores. Neste sentido, destaca que não pode haver um divórcio entre a dimensão política do "organizar" o trabalho com a sua dimensão técnica, assim a atividade de gestão não pode ser tomada apenas como instrumentalista, mas também como intelectual, que se insere num contexto político de desenvolvimento da prática e exige a participação dos professores, alunos e comunidade escolar para sua realização. Portanto, para ele, gestão é a organização de capacidades, de instrumentos, objetivos e ações, que possam contribuir para a melhoria e desenvolvimento institucional, e este desenvolvimento não pode prescindir da participação autêntica das diferentes pessoas que fazem parte do processo educativo.
} 
método científico, para obter eficiência, eficácia e qualidade no processo pedagógico - todos os componentes educacionais (objetivos, administração, estruturas, meios de ensino, custos, tecnologia e outros) devem ser considerados. Manifesta-se, desse modo a tentativa de vincular a educação ao novo paradigma produtivo, na ótica do que se denomina neotecnicismo. Há uma volta ao discurso do racionalismo econômico, do gerenciamentoladministração privado como modelo para o setor público e do discurso do capital humano - formação de recursos humanos. (LIBÂNEO; OLIVEIRA; TOSCHI, 2005, p. 103-104)

Estas duas referências conceituais sobre "gestão" entrariam em confronto com o propósito socialmente crítico e intelectual, uma vez que a gestão escolar não se restringe a práticas de gerenciamento da escola, mas de organização de diferentes situações profissionais, contextuais e situacionais mais complexas e próprias da cultura educativa e institucional.

Todavia, criticidade e autonomia implicam que as práticas organizativas articulem de forma também pedagógica e especificamente cultural o que se faz, neste caso na escola, inclusive por se tratar de um processo essencialmente humano, dialético e de permanentes mudanças impulsionadas por fatores internos e externos, que precisam se voltar prioritariamente para oportunidades de aprendizagem colaborativa.

Concordamos com Tardif (2002), ao defender que os saberes da profissão docente e, portanto dos pedagogos que atuam na gestão escolar, não se restringem ao campo da compreensão teórica, nem tampouco exclusivamente da atividade exclusivamente prática, e sim pela confluência dos elementos que constituem a sua profissionalidade, o que constitui a práxis profissional, implicando a articulação das práticas dos pedagogos que atuam na escola e a compreensão dos princípios e sentido de seus ofícios.

Ainda sob o risco de um novo generalismo acadêmico, baseado na pulverização de conteúdos específicos durante o curso, para Saviani (2008), a orientação curricular do curso de Pedagogia, a partir de 2006, apresenta a possibilidade de uma formação mais plural do pedagogo, mas que também poderia se configurar como uma possível ameaça à formação docente ou dos 
demais profissionais do magistério, se não implantado com critérios claros e qualitativos. Diz ele:

\begin{abstract}
Ora, um aluno que é preparado para o exercício da docência assimilando os conhecimentos elementares que integram o currículo escolar; estudando a forma como esses conhecimentos são dosados, seqüenciados e coordenados ao longo do percurso das séries escolares; compreendendo o caráter integral do desenvolvimento da personalidade de cada aluno no processo de aprendizagem; e aprendendo o modo como as ações são planejadas e administradas, está sendo capacitado, ao mesmo tempo para assumir a docência, para coordenar e supervisionar a prática pedagógica, orientar o desenvolvimento dos alunos e planejar e administrar a escola; e, assegurada essa formação, estará também capacitado a inspecionar o funcionamento da escola (SAVIANI, 2008, p.153).
\end{abstract}

Desta forma, o próprio conceito de gestão precisa ser redimensionado a partir das Diretrizes Curriculares Nacionais da Pedagogia. Neste caso, se buscarmos significados atribuídos ao sentido de gestão escolar e educacional, não deixaremos de encontrar contextos também variáveis, que ora enfatizam a relevância da atuação pedagógica que os profissionais venham a realizar, ora nos faz defrontar com conceituações que mais se aproximam da idéia de gerenciamento da escola, como uma macroestrutura.

Como exemplo da diversidade de elementos que constituem o conceito de gestão, trazemos, em situação de destaque, alguns exemplos de concepções de educadores que demonstram qual a abordagem que adotam acerca desta atividade e campo de trabalho na educação e na escola.

Para Fernandez (2006):

O conceito de Gestão Escolar, relativamente recente, é de extrema importância para que se tenha uma escola que atenda às atuais exigências da vida social: formar cidadãos e oferecer, ainda, a possibilidade de apreensão de competências e habilidades necessárias e facilitadoras da inserção social. Para fim de melhor entendimento, costuma-se classificar a gestão escolar em três áreas, que funcionam interligadas, de modo integrado ou sistêmico: Gestão Pedagógica, Gestão de Recursos Humanos e Gestão Administrativa (FERNANDEZ, 2006, p.130).

A estudiosa entende que gestão se refere à articulação de saberes de diferentes aspectos organizativos da escola e que se aproximam da 
perspectiva de otimização de recursos existentes, vinculada aos processos de exercício de capacidades e competências para a melhoria funcionalista, embora aponte o vínculo que deve ter com a vida social.

Na interpretação de José Carlos Libâneo (2005):

O gestor escolar deve ser um líder pedagógico que apóia o estabelecimento das prioridades, avaliando, participando na elaboração de programas de ensino e de programas de desenvolvimento e capacitação de funcionários, incentivando a sua equipe a descobrir o que é necessário para dar um passo à frente, auxiliando os profissionais a melhor compreender a realidade educacional em que atuam, cooperando na solução de problemas pedagógicos, estimulando os docentes a debaterem em grupo, a refletirem sobre sua prática pedagógica e a experimentarem novas possibilidades, bem como enfatizando os resultados alcançados pelos alunos. O gestor deverá animar e articular a comunidade educativa na execução do projeto educacional, incrementando a gestão participativa da ação pedagógico-administrativa, conduzindo a gestão da escola em seus aspectos administrativos, econômicos, jurídicos e sociais. O gestor é o articulador/mediador entre escola e comunidade. Ele deve incentivar a participação, respeitando as pessoas e suas opiniões, no que chamamos de gestão democrática. Como dirigente, cabe-lhe ter uma visão de conjunto e uma atuação que apreenda a escola em seus aspectos pedagógicos, administrativos, financeiros e culturais (LIBANEO, 2005, p. 332)

Para este pesquisador, o conceito de gestão está vinculado à perspectiva de desenvolvimento de aspectos da escola, com foco na melhoria das práticas e articulação de diferentes segmentos do trabalho escolar, sem conceber que um seja mais determinante que outro. $\mathrm{Na}$ visão deste pesquisador, liderança pressupõe participação colaborativa e solução compartilhada de problemas que possam fazer parte do cotidiano da escola, portanto não é apenas uma medida técnica.

Segundo os estudos e concepção defendida por Paro (2008):

O gestor escolar tem de se conscientizar de que ele, sozinho, não pode administrar todos os problemas da escola. O caminho é a descentralização, isto é, o compartilhamento de responsabilidades com alunos, pais, professores e funcionários. Isso, na maioria das vezes, decorre do fato de o gestor centralizar tudo, não compartilhar as responsabilidades com os diversos atores da comunidade escolar. $\mathrm{Na}$ prática, entretanto, o que se dá é a mera rotinização e burocratização das atividades no interior da escola, e que nada contribui para a busca de maior eficiência na realização de seu fim educativo (PARO, 2008, p. 130). 
Segundo esta perspectiva teórica, gestão do trabalho na escola não se reduz à organização de procedimentos de rotinas ou burocráticas, que muito pouco contribui para a partilha das responsabilidades, o que não permite que os sujeitos tenham consciência crítica acerca dos problemas que fazem parte da escola, em especial das instituições públicas, que tem contextos próprios.

A função, de acordo com Borges (2008), exige mobilização, como afirma:

\footnotetext{
Sua função envolve atividades de mobilização, de motivação e de coordenação. Dirigir uma escola implica colocar em ação os elementos do processo organizacional (planejamento, organização, avaliação) de forma integrada e articulada. Assim, o gestor é a figura que deve possuir e liderança, no clima de organização da escola que pressupõe a liberdade de decidir no processo educativo e não nos gabinetes burocráticos (BORGES, 2008, p. 83).
}

A visão de gestão presente nos estudos de Borges (2008) se relaciona à direção, ou seja, pressupõe a capacidade de decidir sobre o clima da escola, de gerir o processo estratégico de organização da escola, logo a estratégia é tida como competência tão significativa quanto o conhecimento, inclusive, neste caso, estabelece capacidades psicológicas - como a de motivação como determinantes para a eficácia da gestão.

De acordo com o pensamento defendido por Hengemuhle (2004):

Considera-se a Gestão Pedagógica o lado mais importante e significativo da gestão escolar. Cuida de gerir a área educativa propriamente dita da escola e da educação escolar. Estabelece objetivos, gerais e específicos, para o ensino. Define as linhas de atuação de acordo com os objetivos e o perfil da comunidade e dos alunos. Propõe metas a serem atingidas. Elabora os conteúdos curriculares. Acompanha e avalia o rendimento das propostas pedagógicas e dos objetivos e o cumprimento das metas. Avalia o desempenho dos alunos, do corpo docente e da equipe escolar como um todo (HENGEMUHLE, 2004, p. 191).

Neste caso, Hengemuhle (2004) defende gestão escolar como uma forma de priorizar a organização e o desenvolvimento pedagógico da escola, com foco na melhoria do projeto de trabalho, portanto está relacionada à definição de objetivos e metas, derivadas do aspecto pedagógico. 
Esta diversidade de concepções acerca do que se entende como gestão escolar, e portanto como atribuições destinadas aos profissionais que se responsabilizam por tais atividades, é resultante da própria compreensão do papel e do sentido que a escola tem recebido, sobretudo a partir das últimas décadas, no caso brasileiro, em virtude das mudanças ocorridas no campo educacional, tendo a se destacar principalmente cinco aspectos que julgamos relevantes e influentes no que demarcam as referências sobre gestão nos sistemas de ensino:

$\checkmark$ primeiro, no início da década de $1990,83 \%$ dos brasileiros em idade escolar básica eram efetivamente atendidos pela escola, índice que se elevou para $98 \%$ em 2008, segundo dados do INEP, evidenciando que um imenso contingente de excluídos adentrou a escola pública brasileira. Este fato promoveu impacto no perfil da população atendida, fenômeno este que teve início na década de 1960 e passou a exigir outra forma de arranjo institucional;

$\checkmark$ segundo, a Lei de Diretrizes e Bases da Educação Nacional de 1996 ratificou a presença do modelo político federalista na gestão da educação, implicando na definição de papéis para o poder federal e para os demais setores federados, munidos de autonomia para a gestão de seus sistemas, e portanto, para organizarem seus sistemas de funcionamento, algo que se consolidou inclusive pelas novas diretrizes de financiamento. Isto aponta para a necessidade de profissionais responsáveis pela mobilização e implementação do projeto pedagógico;

terceiro, os dados da avaliação do PISA $^{43}$ (2006) indicam que apesar da democratização do acesso à educação, nossas escolas carecem de

\footnotetext{
${ }^{43}$ Programme for International Student Assessment (PISA) é um sistema de avaliação de larga escala, organizado pela OECD da Comunidade Européia e no Brasil coordenado pelo INEP, é aplicado desde o ano 2000, a cada 3 anos, com foco de avaliação a cada edição em uma das áreas de conhecimento, sendo elas: Linguagem, Matemática e Ciências. $\mathrm{O}$ exame aponta $\mathrm{O}$ desempenho dos alunos numa escala de até 600 pontos, sendo que o Brasil obteve a média de 412 pontos em Leitura, 386 pontos em Matemática, e 405 pontos em Ciências, atingindo a média de 401 pontos na edição de 2009. Os dados do PISA, ora demonstrados, indicam que é
} 
uma profunda melhoria nos padrões de qualidade, uma vez que tivemos a $48^{a}$ posição na proficiência em leitura, $52^{a}$ em Ciências, e mais precariamente ainda $53^{a}$ em conhecimentos de Matemática; os dados de 2009 indicam que o Brasil permanece no $54^{\circ}$ lugar de 65 países que participam do exame. Não diferentemente, os resultados do IDEB ${ }^{44}$ (2009), que varia numa escala de 0 a 10, aponta que nos anos iniciais do ensino fundamental os alunos atingiram a média de 4,6 (meta de 4,2 ); nas séries finais do ensino fundamental atingiu 4,0 (meta 3,8); e no ensino médio 3,6 (meta de 3,5); em todos os casos demonstrando que no que tange a desempenho ainda estamos distantes de resultados consideráveis. No entanto, a taxa de aprovação de cada etapa citada anteriormente é de $88,5 \%, 81,3 \%$ e $75,9 \%$, respectivamente, o que demonstra que a mudança das práticas de gestão do acesso e permanência tem apresentado resultados. Por outro lado, em Língua Portuguesa os alunos alcançam nas séries iniciais do ensino fundamental: 184,3 pontos em Língua Portuguesa e 204,3 pontos Matemática; nas séries finais do ensino fundamental 244 pontos em Língua Portuguesa e 248,7 pontos em Matemática; e no ensino médio: 268,8 pontos em Língua Portuguesa e 274,7 pontos em Matemática, apontando que a progressividade da melhoria do desempenho dos alunos no decorrer da vida escolar não é regular;

fundamental que sejam estabelecidos outras formas de gestão do sistema educacional brasileiro, visto que o desempenho dos estados não apresenta abismos entre si; e também mudança nas práticas e experiências de gestão nas escolas, o que exige capacidade e conhecimento dos profissionais responsáveis em lidar com a complexidade da aprendizagem.

${ }^{44}$ O IDEB (Índice de Desenvolvimento da Educação Básica) foi criado pelo INEP em 2007, em uma escala de zero a dez. Sintetiza dois conceitos igualmente importantes para a qualidade da educação: aprovação e média de desempenho dos estudantes em Língua Portuguesa e Matemática. $O$ indicador é calculado a partir dos dados sobre aprovação escolar, obtidos no Censo Escolar, e médias de desempenho nas avaliações do INEP, o SAEB e a Prova Brasil. (www.inep.gov.br). A avaliação do desempenho dos alunos no IDEB é aferida pela aplicação da Prova Brasil, que avalia a proficiência mais enfaticamente em Língua Portuguesa e Matemática, numa escala de 0 a 500 pontos, o que permite avaliar o domínio das mesmas competências (a partir das mesmas questões, que tem variação dos níveis de complexidade atribuídos em cada ano) em diferentes anos da escolaridade e aplicação da prova aos alunos. A meta nacional é a de alcance de índice 6 para os anos iniciais do ensino fundamental até o ano de 2020. 
$\checkmark$ quarto aspecto, destaca sobretudo que a partir da última década (2000), quando os sistemas de ensino, dentre eles e principalmente o de São Paulo, passam a definir medidas de destaque a adesão e sistemas de avaliação baseados em ciclos ou progressão continuada, acompanhados de instrumentos de avaliação de sistema de larga escala, construção de currículo próprio, e de alternativas metodológicas para tratamento da carreira do magistério, muitos dos quais são estritamente vinculados aos resultados do desempenho da escola, e portanto, relacionados à cultura e aos ritos organizativos da escola, algo que apresenta alguns subsídios para a equipe de gestão, mas desprestigia sua autonomia, protagonismo e capacidade criativa;

Evidentemente, este conjunto de medidas de mudança do padrão de gestão de resultados do trabalho e vínculo com políticas de mérito sobre a carreira implica sobre o modo de agir no que se refere às práticas de gestão das unidades escolares.

$\checkmark$ finalmente, um quinto dado se refere às políticas contemporâneas, dos últimos 30 anos de reforma do Estado, que baseada na lógica da eficiência e racionalidade, altera a presença do poder público na gestão dos setores sociais, inclusive no que diz respeito ao financiamento, ao funcionamento e aos mecanismos de controle dos setores públicos, como a escola e todo o sistema de ensino.

Este conjunto de elementos, embora não somente eles, impactaram de forma significativa nas expectativas sobre a forma de organização da escola pública desejada para o alcance exitoso de tal orientação política educacional, de forma geral imposta pelo Estado, em suas diferentes esferas de poder ${ }^{45}$.

\footnotetext{
${ }^{45}$ A obra "Educação Básica no Brasil - construindo o país do futuro", publicada pela editora Campus (2009), apresenta, embora que enfaticamente em dados estatísticos, uma leitura das motivações, impactos e entraves de diversas políticas públicas aplicadas no Brasil, sobretudo a
} 
Por tais circunstâncias, estes elementos imprimem, no âmbito regional e local de trabalho dos gestores escolares, outras formas de definição de prioridade, de organização de suas agendas institucionais, de objetivos e metas, redimensionamento dos conteúdos determinantes para sua formação e dos docentes, além de realocar seu papel profissional nas atividades, na busca de superar a concepção "gerenciamento" de recursos financeiros, materiais e procedimentos administrativos.

Desta feita, o modelo que vai se impondo ao trabalho nas escolas é uma forma contemporânea de organização burocrática na qual o anonimato das decisões não raramente determina todo o processo funcionalista das instituições.

Embora reconheça a existência de sujeitos integrantes dos processos, estes se tornam vítimas de falsas representações de autoridade, de poder e de legitimidade, que quando muito são prepostos das lógicas já estabelecidas, no caso da educação, por uma pedagogia burocrática, que passa a orientar a estruturação da vida dos demais que atuam no cotidiano social das instituições (FORMOSINHO; ARAÚJO, 2007).

Atentemos para o fato de que a Lei de Diretrizes e Bases da Educação Nacional, derivada dos avanços constitucionais de 1988, reconheceu a importância da autonomia para o desenvolvimento das instituições escolares, principalmente no que se refere à flexibilização das alternativas de organização pedagógica, ou seja, toca na autonomia e democratização, mas também incentiva a livre iniciativa.

partir da década de 1990, destacando seus efeitos sobre a expansão do ensino, o impacto da mudança de financiamento, a implementação e a repercussão dos indicadores de avaliação no sistema educacional brasileiro, as evidências acerca da qualidade da educação brasileira com base em elementos estatísticos, as razões relacionadas às políticas de mérito vinculadas à carreira do magistério, assim como o processo de expansão das taxas líquidas de atendimento na educação básica. Ressaltamos, que os organizadores deste trabalho: Fernando Veloso, Samuel Pessoa, Ricardo Henrique e Fábio Giambiagi são todos da área econômica e não da Pedagogia, o que já demonstra a penetração desta ciência no campo da educação, evidenciam os efeitos destas políticas e de seus resultados sobre o funcionamento da educação, permitindo-nos detectar muitos de seus efeitos sobre o trabalho que vem sendo realizado pelos gestores escolares, em virtude da doutrina de gestão indicada pelos sistemas de educação, sejam eles municipais, estaduais ou federal. 
Os dispositivos que a regulamentaram, em especial as inúmeras manifestações do Conselho Nacional de Educação acerca das novas diretrizes para a formação de professores, dariam a orientação para os sistemas de ensino, inclusive em se tratando dos pontos que trouxemos anteriormente, uma vez que a formação dos demais profissionais do magistério, não seria até então objeto de apreciação específica.

Nas últimas décadas do século $X X$, o que toma vulto na sociedade é o discurso de um modelo de gestão do trabalho escolar e educativo baseado numa orientação burocrática de padrões de funcionamento, de planejamento do trabalho pedagógico, de currículo e de dispositivos estruturalistas para o financiamento da educação e mesmo para os processos de gestão da carreira, como a meritocracia. Neste contexto, como se pode definir a idéia de gestão educativa pelo princípio da autonomia?

Firmou-se o desencontro entre o texto legal a ser implementado e as expectativas que realmente poderiam promover a autonomia nas práticas de gestão e de trabalho nas escolas, inclusive com a avalanche de diretrizes, um tanto quanto impositivas, por parte dos órgãos centrais nos sistemas, principalmente a respeito de avaliação, currículo, formação de professores, projetos didáticos, cerceando a construção de um projeto de gestão pela própria escola, mesmo havendo uma organização de sistema.

Normativamente, o Parecer CNE CP 03/06 que orientou a formação a ser desenvolvida nos cursos de Pedagogia e, portanto, dos pedagogos que viriam a atuar nas diversas atividades do magistério, previu um conjunto de atividades profissionais que também seriam imprescindíveis aos docentes. Nestes termos, os legisladores explicitaram o que concebiam, à época, como princípios para atuação dos gestores, a saber:

Parágrafo único. As atividades docentes também compreendem participação na organização e gestão de sistemas e instituições de ensino, englobando:

I - planejamento, execução, coordenação, acompanhamento e avaliação de tarefas próprias do setor da Educação;

II - planejamento, execução, coordenação, acompanhamento e avaliação de projetos e experiências educativas não-escolares; 
III - produção e difusão do conhecimento científico-tecnológico do campo educacional, em contextos escolares e não-escolares (artigo $4^{\circ}$, Lei 9394/96).

Esta concepção expressa pelas relatoras do parecer Clélia Brandão Alvarenga Craveiro e Petronilha Beatriz Gonçalves e Silva demonstra que ao pensar nas demais atividades do magistério, concebe-se a docência como matriz de atuação, e portanto seus saberes são considerados suportes para o desenvolvimento do planejamento, coordenação, supervisão ou administração do trabalho pedagógico e escolar.

Formosinho \& Araújo (2007) sugerem que ao ser implantado, este modelo de gestão dos processos educacionais de autonomia aparente, no qual a burocracia e controle permanecem como referências de organização do trabalho e das intervenções nas práticas de gestão, se instituiu uma forma específica de relação entre a escola, os sujeitos e o poder.

Esta lógica de burocracia aparente provocou compreensões ilusórias sobre as pretensas propostas de avaliação do trabalho pedagógico, de liberdade de construção dos procedimentos cotidianos, de autonomia para manutenção financeira, que na prática são relegadas à margem dos planos ou de discursos intencionais, uma vez que o controle dos mecanismos que podem provocar as mudanças consideradas necessárias são determinantes no trabalho, como afirmam as pesquisadoras:

\footnotetext{
Na sua relação com as escolas, a administração da educação utiliza um juízo de conformidade de meios com meios e não um juízo de conformidade com os meios, com os fins. Se considerarmos que os instrumentos legais que operacionalizam as decisões, sobretudo os decretos-leis, os decretos regulamentares, as circulares funcionam como meios, e não como fins em si, então a maior parte da ação burocrática concretiza-se no juízo da conformidade dos meios práticos utilizados pelas escolas para concretizarem a sua atuação com os meios legais definidos pelo governo, pelos ministros e, no caso dos micro-normativos, pela própria administração. (FORMOSINHO; ARAUJO, 2007, p. 300).
}

Características próprias do sistema educacional brasileiro favorecem a indefinição do que concebemos como gestores escolares, mas que também 
são eminentemente profissionais do magistério, e o que se estabelece como parâmetros de atividades que circunscrevem a profissionalidade de cada um destes ofícios (planejamento, administração, supervisão, inspeção, coordenação e orientação), implicando sobre a ausência de uma identidade destes ofícios que, do ponto de vista sociológico, os afasta do conceito de profissão.

Aspectos como a extensão continental e, consequentemente, as inúmeras unidades federativas; a multiplicidade de formas de organização dos sistemas educativos, como resultado da própria desigualdade econômica, padrões de financiamento, estruturação e qualidade diferenciados; diversificadas formas de provimento dos postos de trabalho de gestores educacionais pelos pedagogos; além dos requisitos legais para ingresso são elementos que preliminarmente sinalizam tal indefinição, que autentica a justificativa de aumento de mecanismos de controle perverso sobre os profissionais e sobre o que fazem.

Os mecanismos de controle existentes, numa forma de organização de trabalho burocrático, também contribuem para a proposição de instrumentos frágeis de articulação dos profissionais, como formas de evidenciar sua pouca capacidade de violação das rígidas normas impostas pelo sistema, o que seria uma forma de se acenar para uma perspectiva de mudança necessária para a continuidade do controle, que permanece detendo as decisões e os rumos a serem tomados.

O princípio de gestão a ser disseminada contemporaneamente não é apenas baseado num rol de procedimentos administrativos ou técnicos, mas é um sistema cultural de organização do trabalho que fortalece a compreensão de que os sujeitos tornam-se cada vez mais responsáveis pelos resultados institucionais, independentemente do valor social e público que lhes é dado e, mais gravemente, do sentido ético e pedagógico do suporte do Estado que Ihe é transferido. 
Nesta mesma perspectiva, os estudos desenvolvidos por Formosinho \& Araújo (2007) tem apontado que ocorre uma mistura de burocracia, controle e limitação da potência criativa das escolas e de seus profissionais:

\begin{abstract}
A comunidade escolar restringe-se aos elementos que podem ser enquadrados na cadeia hierárquica da administração da educação e sujeitos ao poder disciplinar do Estado: professores, funcionários e alunos. Ela não tem autonomia - nem autonomia científica, em autonomia curricular, nem autonomia organizacional, nem autonomia administrativa nem financeira. É um serviço dirigido pelos serviços centrais através de despachos normativos, circulares e instruções diretas, sendo que a sua direção se encontra fora dela (FORMOSINHO; ARAUJO, 2007, p. 320).
\end{abstract}

Esta ilusão de autonomia apontada pelas pesquisadoras limita a atuação dos gestores, confere-lhes mais responsabilidades e expropria-os das condições necessárias para o trabalho, provocando a situação de desprofissionalização, que não se restringe à atuação docente.

Quando a instituição tem, ou consegue ter, um ambiente de trabalho suficiente para a avaliação de suas ações, para a construção de seu projeto, para identificar seu projeto, verificando suas fragilidades, enfrentando os aspectos mais frágeis e ainda compreendendo seu papel cultural nas mudanças que podem ser produzidas acerca das possibilidades de construção de conhecimentos dos seus alunos e profissionais, é sinal de que está aderindo a uma concepção de gestão mais colaborativa, que supera a racionalidade técnica, estritamente baseada em procedimentos burocráticos.

Luck (2009) destaca que esta abordagem colaborativa de gestão escolar não depreende de liderança e que ao contrário, está relacionada à forma pela qual os gestores exercem a liderança institucional, articulando as forças institucionais e enfrentando coletivamente os desafios que vão se apresentando no cotidiano escolar e educativo, como destaca:

A cultura organizacional é aprendida e formada coletivamente, a partir das experiências nas quais um grupo se envolve, na medida da influência de uma liderança, seja formal ou informal, seja intencional ou espontânea. A liderança orientadora do modo de ser e de fazer pode ocorrer de maneira espontânea e em nome de valores pessoais, (resultando em condições muito comumente desfavoráveis aos objetivos educacionais, desde que os valores pessoais não estejam afinados com os educacionais), ou organizada em nome de valores 
sociais e institucionais, mediante liderança efetiva como esse enfoque. Essa cultura na escola é formada pela sua história, em sua vinculação externa com a comunidade, o sistema de ensino de que faz parte, assim como pela dinâmica interna de interações, que marca, de maneira indelével, o modo como os desafios são enfrentados, como as pessoas os percebem e reagem diante deles, dentre outros aspectos. (LUCK, 2009, p.117)

Esta perspectiva participativa e democrática de gestão, no que se refere ao contexto legal brasileiro, está diretamente ligada ao que dispõe o artigo 12 da Lei 9394/96, prevendo a orientação da gestão da escola, pelo projeto pedagógico ${ }^{46}$ que na instituição deve ser construído, e assim deve ser o eixo orientador dos profissionais que desempenham funções de planejamento, direção, coordenação, supervisão e orientação pedagógica.

A concepção de gestão que elegemos como referência a ser desenvolvida nos cursos de Pedagogia e objeto de ações de formação inicial e continuada se contrapõe à lógica cartesiana ou racionalista de respostas às demandas escolares, derivado do modelo weberiano.

Entendemos como Tedesco (1995), que aos gestores escolares cabe a articulação das potencialidades que caracterizam sua instituição, enfrentando os desafios do sistema, inclusive quando se trata da compreensão das políticas educacionais, algo que não é uma tarefa meramente técnica, como afirma o autor:

A conciliação educacional pressupõe, portanto, o reconhecimento do outro e a negociação de formas de trabalho comuns. Ela não elimina o conflito, nem as tensões, nem as diferenças. Não significa uniformidade. É evidente que continuará a haver interesses distintos e tensões entre, por exemplo, as demandas do mercado de trabalho e a formação integral da personalidade, entre os valores particulares das famílias e o universalismo da cultura escolar, entre a autonomia local e a necessidade de coordenação em nível regional ou

\footnotetext{
${ }^{46}$ No Programa Salto para o Futuro, veiculado pela TV ESCOLA, em agosto de 2005, o Prof. Dr. José Cerchi Fusari (FEUSP) participou da mesa de debate, sob o tema "A formação contínua como um dos elementos organizadores do projeto político pedagógico da escola", e na ocasião apontou com profunda pertinência o fato do projeto ser "a alma" da escola, tendo que explicitar a razão de existência institucional, de mobilização dos diferentes sujeitos em torno dos objetivos e metas estabelecidos pela comunidade escolar, de servir como uma carta de intenções tanto aos pais e alunos, como aos professores, dando rumo ao trabalho da escola, e possibilitando que a mesma vá desenhando sua identidade, valorizando a autonomia e a capacidade de contribuição de cada sujeito, inclusive numa demonstração de compromisso político. Esta nos parece ser uma das demonstrações mais evidentes de que a gestão da escola precisa estar à serviço do projeto pedagógico.
} 
nacional. Mas a busca de conciliação cria um mecanismo pelo qual esses conflitos e tensões são resolvidos mediante o diálogo e os acordos para ação (TEDESCO, 1995, p.134).

Concebemos gestão como concepção de organização do trabalho e conjunto de práticas presentes no exercício desta atividade que pressupõe o desenvolvimento colaborativo do trabalho, de modo a contemplar a melhoria da qualidade ${ }^{47}$ do que é realizado na instituição escolar, envolvendo os diferentes segmentos que nela atuam, utilizando as ferramentas operacionais disponíveis e os aportes possíveis, com vistas a resultados qualitativos e à mudança da forma de realizar com maior eficácia o trabalho.

No entanto, não apontamos apenas o aperfeiçoamento dos métodos com base na racionalização ${ }^{48}$ dos processos, apoiado na otimização economicista de recursos e condições, que implica em certa deterioração dos valores relacionais humanos, tendo como efeito um aprofundamento da

\begin{abstract}
47 A discussão sobre qualidade em educação é um tanto quanto diversa, entretanto destacamos a advertência e o conceito de qualidade apresentado em agosto de 2011, na Carta de Campinas, resultante do Seminário de Avaliação e Políticas Públicas Educacionais, em Campinas, que registrou: No que tange à qualidade, parece-nos que a avaliação tem sido utilizada como a redentora dos males da educação, transformando-se em um fim em si mesma. Há uma ilusão social de que avaliar os sistemas garante qualidade. Entende-se que aumentar a proficiência dos estudantes nos exames é o mesmo que elevar a qualidade, sendo esta medida somente por meio de indicadores e dados. Conceito polissêmico tanto do ponto de vista pedagógico, quanto social e político, a qualidade da educação não pode ser compreendida de forma descolada da historicidade do termo, favorecendo uma maneira superficial de entendimento e uso do mesmo. Assim, entendemos a qualidade na educação como um fenômeno complexo que possui determinações intraescolares (currículo, formação docente, gestão escolar, avaliação da aprendizagem, condições de trabalho, infraestrutura das escolas etc.) e extraescolares (condições de vida da população, capital econômico, cultural e social das famílias dos alunos, entorno social da escola, distribuição de renda, violência, entre outros). Disponível em http://blog.centrodestudos.com.br/carta-de-campinas/acessado em15.09.2011
\end{abstract}

${ }^{48}$ O processo de racionalização dos métodos e processos baseia-se nas contribuições teóricas do que atribuímos modernização weberiana, teoria pela qual o alemão Max Weber defendeu a idéia de que os homens são responsáveis e autores permanentes de estruturas lógico burocráticas com a finalidade de maximização de resultados e alcance de metas, baseando-se em ações desencadeadas analiticamente, e pela qual embora o meio de inserção seja determinante para o estabelecimento das necessidades de racionalização, logo os processos sociais não seriam apenas influentes, mas determinantes na definição das formas de controle e burocracia presente nos processos produtivos, econômicos e sociais, assim, ao mesmo tempo que estas dimensões da sociedades tornam-se autônomas na sua maneira de funcionamento e na construção de mecanismos próprios de controle, tem como parâmetro orientador a racionalidade. 
compreensão do mundo de forma fracionada, ora pela sociologia, ora pela ciência, pela moral ou pela produção, mas sim uma concepção e prática de gestão que tenha compromisso com a melhoria da escola pública.

Neste mesmo percurso de entendimento, Casassus (1995) defende que o propósito da modernização está ligado à mudança de orientações e procedimentos, principalmente do ponto de vista das normas e finalidades do trabalho, o que provoca uma forma de gestão das atividades, logo é um fenômeno que tem sido determinante para o pensamento acerca das estruturas burocráticas educativas.

No âmbito das questões educacionais, principalmente nas últimas duas décadas, desenvolveu-se um conjunto de medidas de gestão com a intenção de se configurarem como reformas ${ }^{49}$. Estas afirmaram os pressupostos da administração escolar com intensa aproximação com o modelo empresarial, conjecturando menor regulação e financiamento do Estado, aplicação de medidas de controle típicas de mercado, sob a justificativa de que tais procedimentos se fazem necessários para a melhoria da qualidade educacional, abalada pela significativa expansão do atendimento a quase totalidade dos brasileiros em idade escolar obrigatória.

A introdução deste referencial ideológico de administração tratou de dar conta, de forma até mesmo pouco sutil, de assegurar a mercantilização a educação $^{50}$, supondo que o ensino ou a aprendizagem pudessem ser

\footnotetext{
49 João Palma Cardoso Filho (2009), em seu texto "A política educacional no Estado de São Paulo", tratou de realizar uma retrospectiva sobre as reformas educacionais no Estado de São Paulo, destacando o processo de mudança das orientações do sistema paulista em razão da alternância de poder, ainda que sob a égide de uma mesma orientação partidária, que resultou na sobreposição de medidas pedagógicas, estruturais, e de formação de profissionais da educação, gerando, em que pese alguns avanços nos indicadores da educação, uma relativa descontinuidade das políticas educacionais e na definição de uma orientação para a gestão educacional e escolar que efetivamente apontasse para uma meta a ser perseguida nos últimos 20 anos, principalmente.
}

${ }^{50} \mathrm{Na}$ obra "A falsificação do consenso: simulacro e imposição da reforma educacional do neoliberalismo, de Pablo Gentili (1998), e Frigotto \& Ciavatta (2003) no texto "Educação básica no Brasil na década de 1990: subordinação ativa e consentida à lógica do mercado", os autores, como exemplos, traçam o histórico e as implicações das reformas destinadas à educação brasileira, como forma de racionalização dos recursos destinados para esta área social, a ampliação da mercantilização dos processos educacionais e a aproximação extrema 
abrangidos pela idéia de produto, e que a relação interpessoal na escola pudesse ser enquadrada nos parâmetros de cliente e oferta.

Defendemos, enfaticamente, escola não é empresa, professores não são operários, nem tampouco alunos são clientes, inclusive como sugerem Libâneo, Oliveira e Toschi (2005):

Em todas as reformas educativas, a partir da década de 80 , a questão da qualidade aparece como tema central. Na realidade, a educação busca um novo paradigma, que estabelece o programa da qualidade. Mas esta não pode ser tratada nos parâmetros da qualidade economicista. A escola não é uma empresa. O aluno não é cliente da escola, mas parte dela. É sujeito que aprende, que constrói seu saber, que direciona seu projeto de vida. Além disso, a escola implica formação voltada para a cidadania, para a formação de valores - valorização da vida humana em todas as dimensões. Isso significa que a instituição escolar não produz mercadorias, não pode pautar-se pelo "zero defeito", ou seja, pela perfeição. Ela lida com pessoas, valores, tradições, crenças, opções. Não se pode pensar em "falha zero" objetivo da qualidade total nas empresas. Escola não é fábrica, mas formação humana. Ela não pode ignorar o contexto político econômico (LIBÂNEO; OLIVEIRA; TOSCHI, 2005, p.117).

Não obstante, os riscos estruturais de tal mercantilização da organização escolar e educacional provocariam o fortalecimento de um conceito sobre trabalho pedagógico que poderia ser banalizado ao restringir-se pelo alcance prescritivo de resultados ou metas externos às demandas da escola, ou ainda ser considerado invariavelmente como decorrente da atuação da equipe escolar, sobretudo dos gestores escolares.

Alinhando as condições de trabalho e a complexidade do contexto sócioeducativo que tem marcado o cenário nacional, principalmente com políticas públicas que enfatizam a expansão do atendimento e do acesso e, portanto, ampliação dos sistemas educacionais, nos deparamos com a ênfase nas

do discurso sobre o trabalho dos profissionais do magistério ao daqueles que atuam em organizações privadas e, por conseqüência, tem outros fins para seu trabalho. Uma das severas críticas dos autores é que tais reformas têm sido altamente conservadoras do ponto de vista do esvaziamento do Estado na manutenção dos direitos sociais como a educação pública e a valorização do investimento material como forma de justificar a educação como prioridade política, sem conseguir, no entanto, produzir mudanças efetivas de resultados de desenvolvimento. 
práticas de racionalização, corroborando uma lógica tecnocrática de gestão que se afasta da intelectualidade crítica, na qual deve se fundamentar o trabalho.

Este concepção de organização da escola e modo de trabalho se afasta da construção de uma identidade profissional que quebre o isolamento e supere o disciplinamento das atividades institucionais, sobretudo em relação ao que fazem os profissionais responsáveis pela gestão escolar e aos docentes para os quais devem também dedicar sua atividade de articulação entre a profissionalidade e as demandas contemporâneas educacionais.

Ainda com base nos estudos de Casassus (1995), o fato de a educação estar num cenário de modernização não significa admitir um menor controle do Estado sobre o processo educativo, nem sequer mudanças substantivas na conjuntura das condições para o trabalho nas quais se inserem as escolas, reafirmando um modelo de responsabilização dos sujeitos em relação à instituição como mecanismo de descentralização e valorização dos resultados, como identificador da qualidade educacional.

A qualidade em educação que defendemos não é apenas a qualidade de resultados, de indicadores ou estatísticas, mais aquela que proporciona a realização e o atendimento dos cidadãos em relação aos seus direitos sociais, culturais, materiais, produtivos e econômicos. A propósito, é aquela que contribui para que sejam autônomos para idealizarem seus desejos e compreenderem suas necessidades, sob uma visão crítica e consciente do mundo no qual vivemos.

Não se trata apenas de oferecer possibilidade de acesso para todos, mas também de Ihes garantir oportunidades concretas em relação aos bens culturais, científicos e humanos, para que todos alcancem o que apontamos como qualidade de educação, o que implica em pensar uma forma própria de gestão na educação que possa atender a este objetivo.

Defendemos que a qualidade educacional precisa estar ligada ao sentido da escola pública, que preconiza não ter caráter seletista, dogmático ou baseado no propósito de rentabilidade de resultados viáveis ou lucrativos. 
Tomada como direito, a educação como condição subjetiva de todos, não pode prescindir da promoção da gestão baseada nas práticas sociais que sejam contributivas da construção dos saberes, da humanização e da equidade e, portanto, não se trata apenas de um processo de administração de recursos ou implantação de procedimentos mais estratégicos ou racionais, mas da construção de uma cultura democrática de participação e responsabilidade na organização de todo o trabalho educativo, e esta é uma forma de expressão do seu sentido público de existência.

As considerações de Libâneo (2004) a respeito dos padrões desejados em educação vão ao encontro do que acreditamos. Elas apontam que a qualidade defendida é uma qualidade social que promova:

a) sólido desenvolvimento cognitivo e científico dos sujeitos que protagonizam a escola;

b) promoção de situações que valorizem as práticas e a condição de cidadania e de valores ético e morais significativos;

c) oportunidade democrática de elevação da escolaridade da população, indistintamente;

d) experiências de interação entre a cultura escolar e as outras culturas dos espaços sociais;

e) situação favorável de desenvolvimento profissional dos docentes, assim como equipamento infra-estrutural adequado.

f) incorporação das tecnologias da informação nas situações de aprendizagem;

Também apoiados nestes aspectos, acreditamos que a qualidade em educação tem relação com a qualidade da formação profissional e se intercambiam, uma vez que a primeira é resultante do modo e da eficácia do trabalho desenvolvido, enquanto que a segunda significa $o$ ato de construir algo, neste caso, a profissionalidade do gestor escolar, que precisa se revestir 
desta concepção de qualidade baseada na melhor condição educativa, alcançada pelo profissionalismo.

Isto posto, nos referimos à profissionalização, pois esta pode finalmente representar a transformação da condição de ofício de um determinado exercício de trabalho em uma profissão ${ }^{51}$, dotada de seus atributos próprios. Para Jobert (2003), esta profissionalização, assim como no caso de outros profissionais intelectuais ou manuais, é algo que está inserida no campo das mudanças históricas e sociais, inclusive no das transformações do mundo do trabalho, que não se restringem ao campo pedagógico ou educativo.

No caso dos gestores escolares, temos visto que a própria história recente da Pedagogia tem contribuído para esta dissonância entre profissionalização, profissionalidade e profissionalismo, uma vez que tanto o espaço de formação inicial tem carecido de identidade, como o lócus de sua profissionalidade é, ao mesmo tempo, espaço de antagonismos de interesses, contradições ideológicas, mas também de produção de conhecimento e cultura.

Há de reconhecermos que a gestão passa a ser estratégia do Estado para as reformas educativas sucedaneamente propostas e baseadas nos princípios de eficiência, eficácia e produtividade.

De modo geral, esta concepção e orientação de gestão definida pelos sistemas educacionais é organizada por decisões hierarquizadas com forte transferência de responsabilidade para os protagonistas da escola, o que afronta qualquer perspectiva de gestão mais emancipatória, colaborativa, e que se paute na valorização das culturas institucionais, relegando à escola o papel de executora de programas, projetos ou planos definidos externamente.

\footnotetext{
${ }^{51}$ Vários pesquisadores do campo da educação, dentre os quais, Antonio Nóvoa (PT), José Contreras (ES), Carlos Marcelo Garcia (ES), Maurice Tardif (CN), Claude Dubar (FR), Marisa Vorraber Costa e Maria Isabel de Almeida (BR), tem discutido a pertinência do ofício docente no campo das profissões ou de semi-profissões, considerando alguns fatores como: a situação de expropriação de seus instrumentos e recursos para o trabalho; a sobrerregulação do Estado sobre os fazeres deste profissionais; o aprofundamento das condições extenuantes de trabalho pelas quais nas últimas décadas têm desenvolvido seu trabalho; a precarização das condições de formação inicial e continuada destes profissionais, culminando no empobrecimento dos saberes essenciais ao exercício da profissão; além da profunda desvalorização social e econômica da carreira do magistério.
} 
No âmbito deste modo de se pensar a gestão da escola, assenta-se a exigência de qual gestor escolar é desejado para a realização eficiente deste tipo de prática perversa.

Os aspectos anteriores foram marcantes nas políticas educacionais ${ }^{52} \mathrm{de}$ muitos países da América Latina, a partir da década de 1990, e tomados como determinantes para as ações de gestão de sistema, e as práticas de gestão escolar. Por consequência, passaram a ser decisivos tanto nas matrizes de profissionalização como na profissionalidade dos gestores.

Esta concepção de gestão implica, não raramente, em propostas pragmáticas que impõem aos gestores escolares tarefas ou percursos de trabalho, que recorrentemente servem para atender a uma rotina burocrática ilusionista, que se revestem de aparente poder de ação ou decisão, ou ainda, a finalidades de racionalização dos meios e recursos educacionais disponíveis, sejam eles materiais, financeiros ou humanos. A alienação profissional acaba por marcar a profissionalidade esvaziada de sentido pleno.

Por reconhecer a complexidade da gestão escolar, entendemos que esta composição de trabalho gestor e, consequentemente, da profissionalidade dos que a desenvolvem, não é um conjunto de ações que deva se nortear exclusivamente pelos princípios das teorias da administração, pois a escola situa-se num campo de relações dialéticas que exige a superação da interpretação dicotômica entre as atividades essenciais que são desenvolvidas no seu interior.

\footnotetext{
52 Pesquisas realizadas por Rosa Maria Torres (2001), sistematizadas em especial, na obra "Itinerários pela educação latino-americana" apontam a utilização banalizada que se encontra termos como "reforma, mudança, inovação", como se estes se referissem ao mesmo processo de intervenção numa determinada realidade. A autora, a partir de visitas a muitos países da América Latina, traz um panorama da situação das instituições, dos educadores e de experiências vividas. A pesquisadora distingui que no seu modo de pensar, as reformas são impositivas, "de cima para baixo", enquanto que a "inovação" é um fato que ocorre normalmente em escalas menores, sobretudo na escola, onde as práticas educativas e as políticas se efetivam, e portanto, a autora destaca que nosso grande desafio na gestão da escola é provocar a "mudança educativa" que seria uma forma de lidar com as reformas educacionais de maneira que estas sejam inovadoras, e isto depende da maneira pela qual a escola está organizada.
} 
A dicotomia de compreender a articulação dos fazeres pedagógicos na escola, e que incorre no equívoco de sugestionar que a atividade da docência é subalterna aos "especialistas" de educação, além de não contribuir para a consciência da responsabilidade coletiva institucional, reproduz estratégias de liderança impositiva ou apenas instituída, contribuindo, quase que naturalmente, para $\mathrm{o}$ afastamento entre $\mathrm{si}$, dos pedagogos que atuam na escola, ainda que em atividades correlatas de suporte pedagógico ao trabalho docente.

Enfrentar esta situação de atuação fragmentária e tecnocrática pressupõe que os cursos que formam os profissionais, que atuarão como gestores escolares, sejam mais complexos, integrados e abrangentes no que se refere aos conteúdos formativos propostos e ao perfil profissional dos egressos, de maneira a superarmos o equívoco de se compreender determinadas atividades como algo próprio e possível apenas a um segmento de pedagogos, e isto depende de uma profunda mudança de profissionalização.

Desta forma, quando nos referimos às mudanças educacionais, é incontestável que as práticas de gestão, ou seja, dos profissionais que atuam nas atividades de coordenação, direção, orientação, supervisão ou inspeção escolar não podem prescindir desta consciência reflexiva e de aprofundamento intelectual para a atuação diante dos desafios da educação.

Esta postura profissional é fundamentada, senão pela profissionalização imbricada aos contextos reais dos sujeitos e, desta forma, através da Pedagogia, e do que trazem os egressos de seus respectivos percursos formativos.

\subsection{Dos dilemas conceituais sobre "especialistas" em educação e "gestores escolares": legalidade e atuação}

Discutimos, na seção anterior, o conceito de gestão escolar que julgamos pertinente ao contexto da escola para um trabalho mais 
emancipatório. Neste momento da pesquisa, discutiremos que apesar de terem sido criados novos dispostos legais, não se superou a consagração de certos "especialismos" e, por analogia, da ruptura entre a existência dos profissionais do magistério, vinculados ao suporte pedagógico, e o próprio sentido pedagógico da escola, além do trabalho docente.

Como indicamos anteriormente, a profissionalidade dos que atuam nas atividades do magistério, seja no âmbito da escola pública, seja fora dela, mas em função da organização dos processos educativos, é profundamente afetada não somente pelos contextos formativos, mas também pelos dilemas do mundo do trabalho escolar e pelas alterações que circunscrevem a educação.

Ademais, estamos diante da contradição entre a teoria e a prática, inclusive por que a profissionalização dos gestores escolares também padece de inúmeras alegações sobre a apresentação de uma teoria na formação que não corresponde aos desafios da prática, e esta, por sua vez, é muitas vezes realizada sem significativo aprofundamento crítico, nem tampouco de um pensamento intelectual e cientificamente mais estruturado.

Estudos históricos apontam que os processos de formação dos profissionais da educação, nos séculos XVII, XVIII e XIX, foram basicamente marcados por fundamentos filosóficos e didáticos que primavam pela aprendizagem da instituição.

A partir do século $X X$, passou-se a conceber a educação a partir de fundamentos mais acentuadamente psicológicos acerca do desenvolvimento da aprendizagem, do processo de ensino e da organização educativa. No caso do Brasil, o aspecto psicológico passou a influenciar diretamente as concepções de formação dos especialistas, no curso de Pedagogia.

Assim, os cursos de formação do pedagogo no Brasil, a partir do final da década de 1930, baseavam sua proposta na mesma lógica que orientaria a produção fabril e industrial em expansão, a segmentação do trabalho, a fragmentação das atividades, tendo em vista a especialização como uma alternativa de aprimoramento. No caso da gestão, em virtude do aumento dos 
chamados "Jardins da Infância", era a função de Diretor de Estabelecimento Escolar que tinha destaque.

A partir do final da década de 1960, o fortalecimento de fundamentos psicológicos sobre a educação imprimiria a marca de atividades vinculadas a aspectos mentais, afetivos, emocionais, como forma de mobilização de capacidades para a resolução de problemas ou tomada de decisões, o que contribuiu, no campo da Pedagogia, para o destaque à formação dos orientadores educacionais.

Este encaminhamento dado à Pedagogia demonstrava, ainda timidamente, que diferentes aspectos da atuação precisariam estar juntos aos conhecimentos técnicos, o que contraporia a idéia da especialização, mas a defesa de um conjunto de capacidades, que deveriam estar em função de determinadas tarefas, o que orientaria o princípio da idéia de atividades de gestão.

Um exemplo bastante emblemático de como eram concebidas as atividades de gestão dos processos pedagógicos na escola é o que fica exposto na argumentação do então conselheiro Valnir Chagas, quando da apreciação do que fundamentaria o histórico Parecer CFE 252/69, que trataria das habilitações para as atividades de especialistas no magistério:

\begin{abstract}
A profissão que lhe corresponde é uma só, e por natureza, não só admite como exige, "modalidades diferentes" de capacitação, a partir de uma base comum. Não há, em conseqüência, porque instituir mais de um curso, porquanto mesmo nas habilitações que as universidades e os estabelecimentos isolados venham a acrescentar, a maior parte das disciplinas se repetirá fatalmente em todas, com pouca ou nenhuma adaptação (...) Entendemos que sob o título geral de Curso de Pedagogia, será possível reunir aspectos dos mais variados numa solução capaz de explorar as virtuosidades da nova lei (Parecer CFE 252/69, p.6).
\end{abstract}

O trecho do Parecer que passou a orientar o curso de Pedagogia a partir da década de 1960, expressa claramente a pretensão de uma formação que fosse capaz de encampar as várias demandas para o trabalho do pedagogo, mas, contraditoriamente previa esta profissionalização desejada pela via do "parcelamento das titulações", que passaram a ser chamadas de habilitações. 
Não trataremos, nesta pesquisa, exclusivamente do dilema da diferenciação acerca do conceito de "especialistas em educação e gestores escolares", mas também de como este se insere no campo da formação dos profissionais que se dedicam a tal atividade, que nos parecem mais determinantes que as insígnias de ofício.

Para enfatizar a diferença entre ser especialista ou ser gestor escolar, ou demonstrar a fragilidade das especializações, reiteramos a complexidade das atividades de coordenação, administração, orientação educacional, supervisão ou inspeção escolar, que se circunscrevem no contexto exigente da educação e da profissionalização dos pedagogos, como profissionais do magistério, para os dias atuais.

Podemos nos perguntar em relação à formação que atualmente é proposta para os pedagogos:

1. Há uma lógica de centralização ou descentralização na construção das ações de formação profissional no projeto pedagógico das escolas?

2. Há metodologias mais criativas para a organização do trabalho local, que é diverso em cada escola?

3. Há referências uníssonas que atentam para a possibilidade de autonomia das escolas?

4. Há formas de atuar que concebam o gestor escolar como profissional capaz de articular as necessidades e a valorização das competências institucionais?

5. Há formas de atuação profissional que possam superar a implantação de ações que correm ao largo das demandas emergentes das escolas públicas?

Para nos reportarmos ao que diferenciamos como especialistas em educação e gestores escolares, apontamos que a concepção de escola, e portanto da cultura de organização do trabalho é fundamental para que diferenciemos estas duas perspectivas. 
Neste caso, concebemos a escola como uma organização aprendente, ou seja, espaços que ampliam sua capacidade de desenvolvimento e produção de resultados, principalmente a partir do aproveitamento das competências que serão construídas coletivamente, não se limitando ao domínio apenas de destrezas ou de habilidades.

O Parecer CNE CP 03/06, que revisou o Parecer CNE CP 05/05, e tornou-se base para a definição das Diretrizes Curriculares do Curso de Pedagogia, apontou que a perspectiva de formação dos profissionais da educação, que se dedicariam às atividades de gestão escolar e educacional, não se restringiria a uma compreensão segmentada do trabalho escolar ou de determinadas atividades fragmentadas na escola.

A existência deste dispositivo legal, fruto das manifestações das associações de educadores que o precederam, assim como das discussões que o sucederam, não significava que as atividades do pedagogo não tenham foco próprio de atuação ou atribuições específicas, mas que todos estes profissionais precisam se orientar por um conjunto de competências comuns e necessárias à organização do trabalho pedagógico, como se refere o documento:

As Diretrizes Curriculares para o Curso de Pedagogia aplicam-se à formação inicial para o exercício da docência na Educação Infantil e nos anos iniciais do Ensino Fundamental, nos cursos de Ensino Médio de modalidade Normal e em cursos de Educação Profissional, na área de serviços e apoio escolar, bem como em outras áreas nas quais sejam previstos conhecimentos pedagógicos. A formação oferecida abrangerá, integradamente à docência, a participação da gestão e avaliação de sistemas e instituições de ensino em geral, a elaboração, a execução, o acompanhamento de programas e as atividades educativas. $\mathrm{Na}$ organização do curso de Pedagogia, dever-se-á observar, com especial atenção: os princípios constitucionais e legais; a diversidade sociocultural e regional do país; a organização federativa do Estado brasileiro; a pluralidade de idéias e de concepções pedagógicas, a competência dos estabelecimentos de ensino e dos docentes para a gestão democrática (Parecer CNE CP 05/05, p.6).

Não se trata de um processo restritamente técnico, mas sobretudo intelectual, criativo e pedagógico, pois deriva de aprendizagens que promovem 
a superação de carências que limitam as possibilidades de melhoria da qualidade do que se faz e que evoca a descentralização do poder.

A escola se torna aprendente e ensinante desde que haja uma cultura colaborativa e um clima organizacional voltado para a aprendizagem compartilhada que surgem de experiências pedagógicas significativas entre os sujeitos que integram o processo educativo da escola, o que decorre das condições de trabalho existentes, e isso é um exercício de democracia.

Desta forma, esta tarefa de construção de cultura aprendente não é simples, nem tampouco desafio a ser conquistado por qualquer profissional que seja exclusivamente "habilitado" para o exercício de um posto de trabalho ou uma função burocraticamente instituída.

Construir um clima de trabalho promissor e qualitativo tem a ver com a compreensão sobre a relação entre os diferentes segmentos da escola, sobre os diferentes atores do processo, sobre as diferentes implicações das ações que são desenvolvidas no campo profissional cotidiano dos profissionais da educação.

Pelo sentido complexo e colaborativo que está presente no trabalho escolar, consideramos que seja pertinente uma prática que articule o que é feito pelos diferentes sujeitos de ofício, e é esta articulação com propósitos significativos de organização que reconhecemos como gestão, realizada não por um especialista, por mais que o seja, mas por práticas sustentadas por princípios éticos que considerem o coletivo da escola e do processo educativo.

Assmann (2004) entende que criar este clima colaborativo de trabalho implica em atuar a partir de práticas que se organizem por uma concepção especifista de educação e por uma compreensão circunstanciada pela importância da articulação entre os aspectos complexos deste processo:

É preciso criar climas organizacionais que funcionem como ecologias cognitivas. No plano de execução, não contam apenas as atuações individuais mas o clima organizacional. Não que se esteja supondo um novo tipo de automatismo, ou seja, co-gênese automática entre contextos e individualidades no que se refere ao aprender a aprender. Mas os esforços individuais isolados não criam aprendizagens coletivas. Foi a uma tomada de consciência disso 
que foi amadurecendo temas como o da inteligência coletiva (ASSMANN, 2004, p.93).

Acreditamos que é necessário valorizar as possibilidades criadas pela cultura colaborativa e intelectual. Para Tedesco (1995), a exigência colocada diante dos profissionais da educação e, neste caso, mais especificamente aos gestores escolares, que são os responsáveis pelas atividades de coordenação, planejamento, administração e supervisão, é o desenvolvimento do trabalho em uma perspectiva de que a instituição se configura como uma escola total ${ }^{53}$, como referência a perspectiva orgânica, o que indica a mudança do trabalho, mas também o risco do produtivismo.

Não se pode, no entanto, negar a subjetividade das ações que podem carecer de relações interpessoais, nem tampouco limitar-se a racionalidade da ciência objetiva que permite a análise dos processos e das intenções. Este é um risco do que tem sido chamado de "escolas ou professores totais", que numa visão crítica, devem se caracterizar não pelo "fazer tudo", mas pelo "refletir" em sua totalidade.

Com efeito, o trabalho dos gestores escolares precisa superar o risco de certos modelos de gerenciamento fundamentalista, que indicam uma análise fragmentária da organização da escola, pressupondo que as práticas ora exaustivamente técnico administrativas, ora prioritariamente pedagógicas é a alternativa para se articular o trabalho escolar, preterindo-se que o foco principal das atividades de gestão da escola e das atividades pedagógicas é a garantia da aprendizagem dos alunos e dos profissionais.

\footnotetext{
${ }^{53}$ Fullan e Hargreaves (2000) destacam que as escolas totais não se caracterizam por serem instituições perfeitas, mesmo porque estas, como instituições coletivas, detêm virtudes e limitações. No entanto, desenvolvem seu trabalho de forma a potencializar intensamente suas capacidades, competências e oportunidades, enfrentando, com clareza, suas ameaças e fraquezas, que implicam sobre o clima da escola e impedem, muitas vezes, que as práticas educativas, mesmo que elaboradas e fundamentadas, sejam ineficazes em muito pela sua fragmentação ou pela ruptura entre os princípios institucionais, os objetivos e metas definidos, e as conduta dos protagonistas do projeto.
} 
Afirmamos, pois, que reconhecer a colaboratividade como um imenso desafio para os gestores escolares é uma forma de estabelecer qual será a metodologia organizativa de trabalho, implicando assim em como serão definidas suas condutas diante das muitas variáveis que compõem a escola e demandam um funcionamento orgânico.

Dentre estas variáveis, destacaríamos que cabe essencialmente aos gestores, a organização do espaço, da organização do fluxo de documentos escolares, das prioridades em alocação de pessoal, de elaboração de roteiro de atividades culturais no projeto escolar, da contribuição profícua de cada sujeito, da estrutura e função dos instrumentos avaliativos utilizados na escola, do tratamento do acervo de livros da escola, das oportunidades de presença da comunidade na escola e da atribuição de valor aos momentos formativos na escola, ou fora dela, dentre outros aspectos.

Considerando-se as implicações decorrentes da concepção de gestão sobre a organização do trabalho escolar, inferimos, mais uma vez, que a idéia de formação baseada no paradigma de "especialistas" é insuficiente para se compreender a indissociabilidade de cada aspecto do funcionamento escolar, na constituição de sua integralidade institucional, assim alertemos, não basta apenas a mudança de nomenclatura.

No caso brasileiro, a recente normatização sobre a formação dos profissionais do magistério, mais precisamente em 2006, constatamos que os sistemas educacionais ainda vivem certa indefinição a respeito de quem são esses e o que cabe a estes profissionais na estrutura da educação, além do que lhes é devido nas propostas de carreira do magistério.

Como exemplo desta celeuma acerca dos responsáveis pela gestão pedagógica, apresentamos alguns dados oficiais que demonstram o fato de que nos sistemas de ensino não se tem uma orientação comum sobre as funções compreendidas como necessárias e suas respectivas exigências e campos de atuação, em diversos quesitos, como demonstraremos no quadro a seguir: 


\section{Amostragem dos cargos e funções de suporte pedagógico nos sistemas de ensino ${ }^{54}$}

\section{Redes Estaduais}

\begin{tabular}{|c|c|c|c|c|c|}
\hline Sistema & Funções existentes & Formação exigida & $\begin{array}{l}\text { Formas de seleção e } \\
\text { provimento }\end{array}$ & $\begin{array}{l}\text { Experiência } \\
\text { docente }\end{array}$ & Local de atuação \\
\hline São Paulo & $\begin{array}{l}\text { Supervisor de Ensino, Diretor de } \\
\text { Escola, Professor Coordenador } \\
\text { Pedagógico }\end{array}$ & $\begin{array}{l}\text { Pedagogia para Diretor e } \\
\text { Supervisor e Licenciatura } \\
\text { para Professor } \\
\text { Coordenador }\end{array}$ & $\begin{array}{l}\text { Concurso Público para Supervisor e } \\
\text { Diretor, e processo seletivo para } \\
\text { Professor Coordenador }\end{array}$ & 3 a 10 anos & $\begin{array}{l}\text { Diretoria de Ensino e Escola } \\
\text { para o Supervisor, Escola para } \\
\text { o Diretor e Professor } \\
\text { Coordenador }\end{array}$ \\
\hline Paraná & $\begin{array}{l}\text { Professor, que atuará como } \\
\text { Supervisor Escolar, Orientador } \\
\text { Educacional, Diretor de } \\
\text { Estabelecimento de Ensino }\end{array}$ & Pedagogia & $\begin{array}{l}\text { Concurso para docente com } \\
\text { subseqüente processo seletivo e } \\
\text { eleição para Supervisor, Orientador e } \\
\text { Diretor }\end{array}$ & 3 a 5 anos & Escolas \\
\hline Alagoas & $\begin{array}{l}\text { Diretor de Escola e Coordenador } \\
\text { Pedagógico }\end{array}$ & $\begin{array}{l}\text { Pedagogia e } \\
\text { Especialização em Gestão }\end{array}$ & $\begin{array}{l}\text { Eleição para Diretor e designação em } \\
\text { comissão pela Secretaria de Educação }\end{array}$ & 3 anos & Escolas \\
\hline $\begin{array}{l}\text { Minas } \\
\text { Gerais }\end{array}$ & $\begin{array}{l}\text { Coordenador Pedagógico, } \\
\text { Orientador Educacional, Diretor } \\
\text { de Escola e Supervisor Escolar }\end{array}$ & Pedagogia & $\begin{array}{l}\text { Eleição para Diretor e concurso ou } \\
\text { processo seletivo para os demais }\end{array}$ & 3 a 6 anos & Escolas \\
\hline
\end{tabular}

${ }^{54}$ Esta amostragem se baseou na opção por estados e também por cidades (tanto as capitais, como as localizadas no estado de São Paulo) que tivessem representatividade populacional, e por conseqüência maior abrangência do sistema educacional. Consideramos também a opção por localidades que possibilitassem, assim como no caso das matrizes curriculares dos cursos, uma abrangência geográfica, seja do país ou do estado, para a uma análise mais significativa dos dados, de modo que possam apresentar evidências que se mostram (ou não) presentes em diferentes regiões territoriais. Embora tenha sido feito contato por meio eletrônico com várias outras Secretarias Estaduais e Municipais de Educação, de cidades que se enquadrariam neste perfil de amostragem, apenas as que aqui apontamos deram a devolutiva das informações e dados. 


\begin{tabular}{|l|l|l|l|l|l|}
\hline $\begin{array}{l}\text { Espírito } \\
\text { Santo }\end{array}$ & $\begin{array}{l}\text { Coordenador Pedagógico, } \\
\text { Diretor de Escola e Pedagogo }\end{array}$ & Pedagogia & $\begin{array}{l}\text { Concurso Público ou designação pela } \\
\text { Secretaria }\end{array}$ & 3 a 5 anos & Escolas e Secretaria \\
\hline $\begin{array}{l}\text { Rio de de } \\
\text { Janeiro }\end{array}$ & $\begin{array}{l}\text { Coordenador Pedagógico, } \\
\text { Diretor de Escola e Inspetor } \\
\text { Escolar }\end{array}$ & $\begin{array}{l}\text { Licenciaturas para } \\
\text { coordenador e Pedagogia } \\
\text { para os demais }\end{array}$ & $\begin{array}{l}\text { Concurso para Inspetor Escolar e } \\
\text { processo seletivo além de indicação } \\
\text { para os demais }\end{array}$ & 3 a 5 anos & Escolas e SEE \\
\hline $\begin{array}{l}\text { Rio Grande } \\
\text { do Sul }\end{array}$ & $\begin{array}{l}\text { Coordenador Pedagógico, } \\
\text { Orientador Educacional, Diretor } \\
\text { de Escola e Supervisor } \\
\text { Educacional }\end{array}$ & Pedagogia & $\begin{array}{l}\text { Eleição para Diretor e concurso ou } \\
\text { processo seletivo para os demais }\end{array}$ & 3 a 8 anos & Escolas e SEE \\
\hline
\end{tabular}

Redes Municipais de Capitais de Unidades Federativas

\begin{tabular}{|l|l|l|l|l|}
\hline Sistema & Funções existentes & Formação exigida & Formas de seleção e provimento & $\begin{array}{l}\text { Experiência } \\
\text { docente }\end{array}$ \\
\hline São Paulo & $\begin{array}{l}\text { Supervisor Escolar, Diretor de Escola e } \\
\text { Coordenador Pedagógico }\end{array}$ & Pedagogia & Concurso & 3 a 6 anos \\
Curitiba & $\begin{array}{l}\text { Coordenador Pedagógico, Diretor de } \\
\text { Escola e Pedagogo }\end{array}$ & Pedagogia & $\begin{array}{l}\text { Processo seletivo de designação, } \\
\text { acompanhado de eleição pela } \\
\text { comunidade escolar }\end{array}$ & 3 anos \\
\hline Porto Velho & $\begin{array}{l}\text { Supervisor Escolar, Orientador } \\
\text { Educacional e Gestor Escolar }\end{array}$ & $\begin{array}{l}\text { Pedagogia } \\
\text { Concurso ou processo seletivo }\end{array}$ & Não requerido \\
\hline Florianópolis & $\begin{array}{l}\text { Coordenador Pedagógico, Orientador } \\
\text { Educacional e Diretor de Escola }\end{array}$ & $\begin{array}{l}\text { Licenciatura para } \\
\text { Diretor e Pedagogia } \\
\text { para os demais }\end{array}$ & Concurso e Escolas & Escolas \\
\hline
\end{tabular}




\begin{tabular}{|c|c|c|c|c|c|}
\hline Porto Alegre & $\begin{array}{l}\text { Supervisor Escolar, Orientador } \\
\text { Educacional, Diretor de Escola, } \\
\text { Coordenador Pedagógico }\end{array}$ & $\begin{array}{l}\text { Pedagogia ou Pós- } \\
\text { Graduação em } \\
\text { Educação }\end{array}$ & $\begin{array}{l}\text { Concurso para docente, seguido de } \\
\text { eleição para os demais cargos }\end{array}$ & 3 a 5 anos & Escolas \\
\hline Recife & $\begin{array}{l}\text { Coordenador Pedagógico, Orientador } \\
\text { Educacional e Supervisor de Ensino }\end{array}$ & Pedagogia & $\begin{array}{l}\text { Eleição para Diretor, processo seletivo } \\
\text { para os demais }\end{array}$ & 3 a 6 anos & Escolas e SEE \\
\hline Vitória & $\begin{array}{l}\text { Diretor de Escola e Especialista } \\
\text { Educacional }\end{array}$ & Pedagogia & Eleição pela comunidade escolar & 3 anos & Escolas \\
\hline Fortaleza & $\begin{array}{l}\text { Supervisor Escolar ou Coordenador } \\
\text { Pedagógico, Orientador Educacional e } \\
\text { Diretor de Escola }\end{array}$ & Pedagogia & Processo Seletivo ou indicação & 3 a 5 anos & Escolas \\
\hline
\end{tabular}

\section{Redes Municipais de Cidades do Estado de São Paulo}

\begin{tabular}{|l|l|l|l|l|}
\hline Sistema & Funções existentes & Formação exigida & Formas de seleção e provimento & $\begin{array}{l}\text { Experiência } \\
\text { docente }\end{array}$ \\
\hline Santo André & $\begin{array}{l}\text { Diretor de Escola, Coordenador de } \\
\text { Serviço Educacional }\end{array}$ & $\begin{array}{l}\text { Pedagogia para o } \\
\text { Diretor e } \\
\text { Licenciatura para o } \\
\text { Coordenador }\end{array}$ & Designação de professor titular & Escolas \\
\hline Avaré & $\begin{array}{l}\text { Supervisor de Ensino, Diretor de Escola e } \\
\text { Professor Coordenador }\end{array}$ & $\begin{array}{l}\text { Pedagogia para } \\
\text { todos }\end{array}$ & $\begin{array}{l}\text { Concurso para Diretor e Supervisor e } \\
\text { designação para Professor } \\
\text { Coordenador }\end{array}$ & 5 anos \\
\hline $\begin{array}{l}\text { Bragança } \\
\text { Paulista }\end{array}$ & $\begin{array}{l}\text { Supervisor Escolar, Diretor de Escola e } \\
\text { Professor Coordenador }\end{array}$ & $\begin{array}{l}\text { Pedagogia e } \\
\text { Licenciatura com } \\
\text { Especialização }\end{array}$ & $\begin{array}{l}\text { Concurso para Diretor, Nomeação em } \\
\text { Comissão para Professor Coordenador } \\
\text { e Supervisor }\end{array}$ & \begin{tabular}{l}
5 anos \\
\hline
\end{tabular} \\
\hline
\end{tabular}




\begin{tabular}{|c|c|c|c|c|c|}
\hline Guarulhos & $\begin{array}{l}\text { Supervisor Escolar, Diretor de Escola, } \\
\text { Coordenador Pedagógico }\end{array}$ & $\begin{array}{l}\text { Pedagogia para } \\
\text { todos }\end{array}$ & $\begin{array}{l}\text { Concurso para Diretor e Supervisor e } \\
\text { processo seletivo para o coordenador }\end{array}$ & $\begin{array}{l}8 \text { anos, } 5 \text { anos e } 3 \\
\text { anos, } \\
\text { respectivamente }\end{array}$ & SME e Escolas \\
\hline São Caetano & $\begin{array}{l}\text { Diretor de Escola, Coordenador } \\
\text { Pedagógico e Orientador Pedagógico }\end{array}$ & $\begin{array}{l}\text { Pedagogia para } \\
\text { todos }\end{array}$ & Livre provimento - nomeação & Não requisitado & Escolas \\
\hline Jales & $\begin{array}{l}\text { Supervisor Escolar, Diretor de Escola e } \\
\text { Professor Coordenador }\end{array}$ & $\begin{array}{l}\text { Pedagogia para } \\
\text { todos }\end{array}$ & $\begin{array}{l}\text { Nomeação de livre provimento para } \\
\text { Supervisor, Concurso para Diretor e } \\
\text { Processo Seletivo para Professor } \\
\text { Coordenador }\end{array}$ & $\begin{array}{l}8 \text { anos, } 5 \text { anos, e } 3 \\
\text { anos }\end{array}$ & SME e Escolas \\
\hline $\begin{array}{l}\text { São Bernardo } \\
\text { do Campo }\end{array}$ & $\begin{array}{l}\text { Diretor de Escola, Coordenador } \\
\text { Pedagógico, Orientador Pedagógico e } \\
\text { Supervisor de Ensino }\end{array}$ & $\begin{array}{l}\text { Pedagogia para } \\
\text { todos }\end{array}$ & Concurso para todos os cargos & 3 a 8 anos & Escolas \\
\hline Hortolândia & $\begin{array}{l}\text { Supervisor Escolar, Diretor Escolar e } \\
\text { Coordenador Pedagógico }\end{array}$ & $\begin{array}{l}\text { Pedagogia para } \\
\text { todos }\end{array}$ & $\begin{array}{l}\text { Processo Seletivo para todos os } \\
\text { cargos }\end{array}$ & 5 anos & SME e Escolas \\
\hline Ourinhos & $\begin{array}{l}\text { Diretor de Escola e Coordenador } \\
\text { Pedagógico }\end{array}$ & $\begin{array}{l}\text { Pedagogia ou Pós- } \\
\text { Graduação em } \\
\text { Educação }\end{array}$ & Nomeação em comissão & 5 anos & Escolas \\
\hline $\begin{array}{l}\text { Ribeirão } \\
\text { Preto }\end{array}$ & $\begin{array}{l}\text { Coordenador, Diretor de Escolar, } \\
\text { Supervisor de Ensino }\end{array}$ & $\begin{array}{l}\text { Pedagogia ou } \\
\text { Especialização em } \\
\text { Gestão }\end{array}$ & Concurso Público e Processo seletivo & 3 anos & Escolas \\
\hline Barretos & $\begin{array}{l}\text { Coordenador Pedagógico, Orientador } \\
\text { Pedagógico, Supervisor de Ensino e }\end{array}$ & Pedagogia & $\begin{array}{l}\text { Processo seletivo e designação pelo } \\
\text { executivo }\end{array}$ & 3 a 5 anos & Escolas \\
\hline
\end{tabular}




\begin{tabular}{|c|c|c|c|c|c|}
\hline & Diretor de Escola & & & & \\
\hline Jundiaí & $\begin{array}{l}\text { Coordenador Pedagógico, Diretor de } \\
\text { Escola e Supervisor Educacional }\end{array}$ & Pedagogia & $\begin{array}{l}\text { Concurso para Diretor, seleção e } \\
\text { designação para os demais }\end{array}$ & 3 a 8 anos & Escola e SME \\
\hline $\begin{array}{l}\text { Mogi das } \\
\text { Cruzes }\end{array}$ & $\begin{array}{l}\text { Coordenador Pedagógico, Diretor de } \\
\text { Escola e Supervisor de Ensino }\end{array}$ & Pedagogia & $\begin{array}{l}\text { Concurso público e processo seletivo } \\
\text { interno para os docentes }\end{array}$ & 3 a 5 anos & Escolas e SME \\
\hline $\begin{array}{l}\text { São José dos } \\
\text { Campos }\end{array}$ & $\begin{array}{l}\text { Orientador Educacional, Coordenador } \\
\text { Pedagógico, Diretor de Escola, } \\
\text { Supervisor de Ensino }\end{array}$ & Pedagogia & Concurso público e avaliação seletiva & 3 a 6 anos & Escolas e SME \\
\hline Araçatuba & $\begin{array}{l}\text { Coordenador Pedagógico, Orientador } \\
\text { Educacional, Diretor de Escolar e } \\
\text { Supervisor de Ensino }\end{array}$ & Pedagogia & $\begin{array}{l}\text { Processo seletivo para coordenador e } \\
\text { orientador, concurso para Diretor e } \\
\text { Supervisor }\end{array}$ & 5 a 8 anos & Escolas e SME \\
\hline Tupã & $\begin{array}{l}\text { Diretor de Escola e Coordenador } \\
\text { Pedagógico }\end{array}$ & Pedagogia & Processo seletivo e designação & 3 a 5 anos & Escolas \\
\hline
\end{tabular}


Embora não tenhamos apresentado os dados de todos os sistemas educacionais brasileiros, inclusive devido à diversificação das realidades e a própria morosidade ou negação dos sistemas no fornecimento de tais dados, o que acreditamos ficar explicitado é uma tendência de como estão dispostos os cargos e funções pedagógicas pelos sistemas de ensino das redes estaduais e grandes capitais do país, assim como de cidades de grande expressão populacional do estado de São Paulo.

Se por um lado, podemos inferir que esta diferenciação é resultante da autonomia dos sistemas de ensino, pressuposto fundamental em um estado democrático; por outro, a fragilidade de referências mais abrangentes do que se entende como tempo de experiência docente para o exercício destas atividades, habilitação apenas em Pedagogia ou especialização, sobreposição de papéis de coordenador e orientador em alguns sistemas, por exemplo, além da diferenciação das formas de provimento de cargos da mesma natureza, implica também na provável ampliação do que se define como identidade formativa do pedagogo para estas atividades.

Pelos quadros anteriormente apresentados, percebemos que os sistemas de ensino também se encontram em processo de compreensão e definição da identidade, ainda incerta, dos profissionais da gestão escolar em seus quadros profissionais, diferenciando-se quanto aos cargos, à experiência de docência, à titulação exigida para provimento dos cargos e funções e, consequentemente, às atribuições destinadas para cada segmento dentro do sistema.

Note-se que todos os cargos ou funções de gestão existentes nos sistemas de ensino, que exemplificamos, se fundamentam em saberes essencialmente pedagógicos, há ainda em duas localidades das pesquisadas (em Florianópolis e Rio de Janeiro, para cargos que não seja o de Diretor de Escola), a não exigência da formação em Pedagogia para o exercício de tais funções, supondo que exclusivamente as disciplinas chamadas de 
pedagógicas ${ }^{55}$, das licenciaturas diversas, sejam suficientemente satisfatórias para tal formação e atuação.

Em outro aspecto, a exigência da experiência docente é um aspecto comum dos sistemas exemplificados, o que corrobora a idéia de que a prática docente é considerada fundamental para o exercício das demais funções de planejamento, coordenação, administração, orientação, inspeção e supervisão em educação.

Contudo, a exigência de experiência apenas docente pode avalizar que sejam compreendidos alguns aspectos deste ofício do pedagogo, mas não garante que as bases formativas, para o cumprimento das atribuições a eles destinadas, sejam realizadas efetivamente, superando a lógica de hierarquização de tarefas.

Há ainda uma correspondência entre os sistemas cujo provimento das funções ou cargo se dá de forma livre, e a não solicitação de alguns dos requisitos que julgamos fundamentais para o exercício desta atividade: o tempo no magistério e a licenciatura plena em Pedagogia.

Nos sistemas nos quais o provimento se dá por concurso público de provas e/ou títulos, a Pedagogia é sempre solicitada como titulação exigível para o exercício da atividade, e nestes também há exigência de tempo de experiência docente e, em alguns, a pós-graduação em gestão escolar ou educacional é colocada como requisito.

\footnotetext{
${ }^{55}$ Apesar de não ser objeto de investigação, nem tampouco elemento de aprofundamento teórico desta pesquisa, apontamos que de modo geral, os cursos de licenciaturas para a formação de professores da educação básica, regidos pela Resolução CNE CP 01/02, não tem a rigor um conjunto de disciplinas obrigatórias, o que podemos considerar como louvável, tendo em vista a referência de tal dispositivo regulamentador à obrigatoriedade de conhecimentos: específicos da área do saber, pedagógicos, didáticos e metodológicos, e educacionais, com a obrigatoriedade do estágio e da prática profissional em situações não periféricas do curso. Todavia, o estudo realizado sobre as licenciaturas por Gatti \& Barretto (2009) aponta a existência de uma realidade bacharelesca nestes cursos, que restringem os conteúdos de formação docente a disciplinas como Didática, Psicologia da Educação, Organização do Sistema Educacional e Prática de Ensino (e eventualmente, alguma outra disciplina de Fundamentos da Educação). O que apesar da relevância destas disciplinas formativas reduz significativamente as possibilidades de compreensão da profissão docente.
} 
Destacamos que a função de Diretor de Escola está presente em todos os sistemas de ensino, diferentemente da coordenação pedagógica ou da supervisão escolar, o que indica, de certa forma, que os aspectos organizacionais da escola, sobretudo o que está ligado aos elementos de seu funcionamento cotidiano, têm destaque nos sistemas de ensino.

Esta condição desvela o valor ainda dado às práticas de administração da escola, preterindo-se a sistematização do trabalho pedagógico com os professores, ou articula as práticas escolares por meio do projeto pedagógico, bem como o conjunto do que se faz na escola com as políticas educacionais orientadoras do sistema.

Percebe-se ainda que, em todos os sistemas, a função de direção de escola, exercida por pedagogos é existente, embora em alguns sistemas já se atribua o título de gestor escolar, o que demonstra que ao se referir a atividades de gestão escolar existe uma associação direta com as práticas de administração escolar.

Mesmo com o grande valor devido à direção de escola, esta ênfase pode nos fazer incorrer em situação que venha a preterir as atividades de coordenação, planejamento ou supervisão em educação, uma vez que, historicamente, a atividade de direção está relacionada à organização das rotinas e dos fluxos escolares, algo equivocado se não houver, prioritariamente, o desenvolvimento institucional e pedagógico da escola.

Ainda no caso dos Diretores de Escola, constata-se um forte movimento de provimento do cargo pelo processo de eleição pela comunidade escolar ou pelos pares, o que difere dos demais cargos, nos quais há forte presença de processos seletivos mistos, ou concurso público de provimento de cargo, como no caso do Estado de São Paulo, que implica esta forma na maioria dos sistemas municipais do estado.

É concebível também, que esta tendência acerca das formas de provimento do cargo de Diretor de Escola esteja diretamente ligada ao conceito ou controle de poder nos sistemas. 
Se analisarmos a tendência percebida no caso dos coordenadores pedagógicos, verificamos que a presença deste profissional tem ocorrido em praticamente todos os sistemas de ensino e, em muitos casos, juntamente ao orientador educacional, o que implica numa compreensão clara e objetiva de seus papéis no desenvolvimento pedagógico da escola, que aparentemente é eleito como um foco do trabalho escolar.

Como não se poderia desejar, não há uniformidade na organização dos sistemas quanto ao ofício dos gestores escolares, todavia em muitos sistemas estaduais e municipais ainda permanecessem com modalidades menos estáveis de seleção destes profissionais, o que demonstra a emergência da construção de uma carreir ${ }^{56}$ mais consistente e valorizada para o magistério, e portanto comprometida também com o desenvolvimento profissional.

Situação análoga ocorre no caso dos supervisores, na qual encontramos referência à supervisão escolar, educacional, pedagógica ou de ensino, e neste caso, o que aparentemente pode remeter apenas a uma distinção de nomenclatura entre os sistemas, reflete uma compreensão maior do processo educacional e o papel destes profissionais no sistema, assim aproximando-os mais dos fazeres escolares e da gestão do projeto pedagógico.

Todavia, é fundamental destacar que o trabalho da supervisão se apóia na ligação entre a escola e o sistema, à luz das políticas públicas, ou das demandas e comandos institucionais do poder central, atuando no sentido de garantir a implantação das diretrizes dos sistemas, o que está diretamente

\footnotetext{
${ }^{56}$ Registra-se ainda que a ambigüidade acerca da formação dos gestores escolares, e a ambigüidade na sua profissionalidade foram conjugadas a deterioração da carreira do magistério nos últimos anos, período no qual se tornou recorrente o tratamento da carreira quase que exclusivamente à formação continuada dos profissionais, empobrecendo o sentido da mesma. Notável exemplo desta situação é encontrado na rede estadual de São Paulo, desde meados da década de 1990, quando da Lei Complementar 836/97, sob a gestão de Teresa Roserley Neubauer da Silva, na Secretaria da Educação, houve o enfoque nas ações ditas de formação. Somente a partir de 2011, com a gestão do Secretário Herman Jacobus Cornelis Voorwald e seu Adjunto João Palma Cardoso Filho é retomada a discussão de carreira com a rede e as entidades de classe, incorporando as questões de formação, salário e condições de trabalho dos profissionais do magistério. Apesar de um Plano de Carreira não ter sido concretizado, o aceno com a situação da valorização do magistério sinaliza que algo de muito errado acontece na carreira, no âmbito na SEE SP, nos últimos 20 anos, no mínimo.
} 
vinculado à forma de provimento que é estabelecida para este cargo, neste caso, é importante que analisemos o papel atribuído à supervisão.

Esta situação está ligada a uma grande indagação acerca da profissionalização e profissionalidade daqueles que atuarão neste ofício: que supervisores queremos e necessitamos? E portanto, o que a Pedagogia oferece para que tais profissionais sejam formados, como também no caso de diretores, coordenadores e orientadores?

A condição híbrida que notamos mesmo entre municípios da mesma unidade federativa, no caso de São Paulo, ou entre grandes cidades no país, reflete que as competências ${ }^{57}$ exigidas para o exercício das atividades de gestão necessitam da definição de um perfil profissional, construídos principalmente nas situações iniciais de formação.

Ora, num cenário nacional no qual se reconhece tanta diversidade, aproximando-se da indefinição, dos campos de atuação para os pedagogos que trabalham nas atividades de suporte pedagógico, é possível se supor que o desafio de uma diretriz nacional de formação para tais profissionais padece da insuficiência de elementos de referência para tal profissionalização inicial.

Podemos inferir ainda que esta pluralidade de condições acerca da existência do trabalho dos pedagogos, que atuam nas atividades de suporte pedagógico nos sistemas de ensino, reflete, ainda que parcialmente, a concepção educacional orientadora de cada sistema, a análise que fazem

57 Segundo Rios (2001), o termo "competência" pode ter surgido em substituição pretensamente mais abrangente para termos como "capacidade, habilidade, conhecimento", de modo a permitir uma maior flexibilização e amplitude da expressão que fazemos uso para nos referir a algo realizado com maior e melhor qualidade, como se os termos anteriormente citados, isoladamente não fossem mais capazes de incorporar toda a complexidade de "competência". Entretanto, a autora alerta que apesar desta possibilidade de ampliação do entendimento acerca do conjunto de atributos que devem estar presentes nos profissionais para a realização do trabalho com maior êxito, o que se tem percebido é a apropriação abusiva do termo "competência", como se esta condição fosse resultante apenas das iniciativas e intenções mais individuais dos profissionais, que pressionados pelos documentos oficiais são aclamados ao exercício de todas suas capacidades para o alcance de melhores resultados, sem que as condições concretas da realização do trabalho pouco sejam alteradas. Neste sentido, julgamos que há virtude na adoção do termo "competência" desde que a concepção pela qual se expressa considere a complexidade dos sujeitos, dos espaços e entorno do trabalho, das condições de exercício profissional, dos elementos que constituíram a formação destes atores, e da consciência profissional. 
acerca do trabalho a ser desenvolvido pela escola e seus profissionais, as competências que precisam ser desenvolvidas na e da escola pública, e também a perspectiva de formação pedagógica que é desejada pelos sistemas de ensino no âmbito das unidades escolares.

Vieira (2009) já apontou que ao tratarmos da atuação dos gestores escolares, precisamos também apontar que a própria história da Pedagogia, traz marcas de fragmentação e hierarquização, assim como o modo de se pensar a organização da escola.

Com efeito, é esta mudança conceitual que ratificaria a impropriedade da habilitação de profissionais da educação para atuarem como especialistas, que teoricamente adquiriam as bases para o trabalho pelo acúmulo de certificações vinculadas e complementares.

(...) no entanto, tudo isso é passado; quem pretendia obter habilitação, por apostilamento em Administração Escolar de $1^{\circ}$ e $2^{\circ}$ Graus, Supervisão Escolar de $1^{\circ}$ e $2^{\circ}$ Graus e Orientação Educacional, já deve tê-la obtido. Hoje, os conceitos sobre a amplitude da formação e da atuação dos professores de Educação Básica são distintos, porque a organização das escolas e dos demais órgãos dos sistemas de ensino também está diferente, especialmente pelos efeitos da gestão democrática e da maior qualificação de todos os profissionais da educação escolar. Não há mais habilitações no Curso de Pedagogia, com ingresso a partir de 2007 ou mesmo para os que ingressarem antes, mas foram conduzidos por suas respectivas instituições formadoras a um projeto de curso já atualizado (Parecer CNE CP 09/2009) ${ }^{58}$.

Como já se presumiria dos próprios títulos das disciplinas ${ }^{59}$, presentes nos cursos de Pedagogia, desde o final da década de 1930, essas

\footnotetext{
58 Parecer CNE CP 09/2009, que consubstanciou resposta à Faculdade de Educação da Universidade Federal de Minas Gerais acerca do Esclarecimento sobre a qualificação dos Licenciados em Pedagogia antes da Lei $n^{\circ}$ 9.394/96, para o exercício das atuais funções de gestão escolar e atividades correlatas e sobre a complementação de estudos, com apostilamento.

${ }^{59}$ O Parecer CFE 252/69 ratificava a existência de muitas disciplinas existentes no curso de Pedagogia, sob a lógica da "especialização dos profissionais", o que poderia ser notado pela presença de disciplinas como: Estrutura e Funcionamento do Ensino, Orientação Vocacional, Medidas Educacionais, Inspeção da Escola, Administração da Escola, Princípios e Métodos, Estatística aplicada à educação, e ainda fragmentando seu oferecimento em módulos relacionados ao $1^{\circ} \mathrm{grau}, 2^{\circ}$ grau ou ensino superior, em alguns casos.
} 
demonstravam seu caráter estruturalista e instrumentalista, pouco destacando as questões emergentes na educação, tendo perdurado até meados dos anos 1990, lançava-se a identificar e a operacionalizar os mecanismos burocráticos de controle ou quando muito, a regulação da escola, e atualmente o papel dos gestores no sistema.

Face às incertezas em relação à formação dos profissionais do magistério, que atuariam nas atividades de suporte pedagógico ${ }^{60}$, no texto da LDBEN de 1996, a perspectiva de as escolas passarem a ter relativa autonomia de gestão dos seus processos, mesmo que no contexto da proposta de modernização do Estado, inaugurou a necessidade de formação de tais profissionais para as atividades de gestão escolar e para a gestão educacional $^{61}$ como concepções menos estratificadas do pensamento de organização do trabalho educativo.

O fato da fragmentação epistemológica não ser apenas marca da formação dos gestores escolares, mas uma característica do processo educacional brasileiro tornou-a instrumento de controle, de domínio de classes, de popularização ideológica e por tal natureza, reafirmou a aproximação da estrutura educacional com procedimentos fundamentalmente voltados à eficiência e racionalização, fundamentos do sistema econômico.

Este padrão de gestão corrompe o princípio fundamental de se preservar a educação como direito social e portanto, setor no qual a

${ }^{60}$ Termo utilizado, inicialmente, no plano de carreira da Secretaria de Educação do Estado de São Paulo para designar os profissionais que atuariam nas atividades de planejamento, coordenação, administração e supervisão educacional, nos termos da lei complementar 836/97. Este termo foi progressivamente adotado por outros sistemas de ensino para referência aos mesmos profissionais.

${ }^{61}$ Diferimos aqui estas duas perspectivas de trabalho, que, na verdade, são indissociáveis: a gestão educacional compreende as políticas públicas da educação, portanto a atividade de normatização e estabelecimento de diretrizes e regulação de todo o sistema; e a gestão escolar se refere às atividades próprias de organização do trabalho institucional das unidades, que mesmo sob a jurisdição a um sistema, define alternativas próprias de organização dos saberes pedagógicos, da alocação de recursos, da relação com o entorno, de propostas que destaquem a melhoria do trabalho realizado e os resultados de aprendizagem. Contudo, há de se resguardar que em ambas as perspectivas da atividade de gestão, o fazer pedagógico, aprendizagem dos sujeitos, e o desenvolvimento profissional e institucional precisam se configurar como essência do trabalho, sob o risco da gestão perder seu sentido pedagógico. 
valorização dos profissionais é fundamental para seu desenvolvimento, provocando impasses, como apontou Oliveira (2008), no qual em países como o Brasil, a educação é tida como uma despesa para o Estado.

Aliado a isto os resultados de aprendizagem ou mesmo de desempenho e desenvolvimento dos sistemas de ensino ainda carecem de melhoria significativa, recursos são normalmente vinculados a índices do sistema, ou vice versa, o que implica em padrões de orientação do trabalho de gestão dos sistemas educacionais e da escola.

Para Vieira (2009), a gestão escolar, a partir da década de 1990, precisa se tornar uma forma de metacompreensão do trabalho da escola, dos seus profissionais e do seu projeto institucional, que será otimizado pela articulação dos diferentes aspectos da organização escolar. Assim, no seu trabalho, com o qual concordamos, aponta que,

\footnotetext{
São tarefas específicas da escola a gestão de seu pessoal, assim como seus recursos materiais e financeiros. Noutras palavras, cabe a ela gerir seu patrimônio imaterial e material. $O$ primeiro refere-se às pessoas, às idéias e à cultura produzida em seu interior; o segundo diz respeito a prédios e instalações, equipamentos e laboratórios, livros, enfim, tudo aquilo que se traduz na parte física de uma instituição escolar. Além dessas atribuições, e acima de qualquer outra dimensão, porém, está a incumbência de zelar pelo que constitui a própria razão da escola - o ensino e a aprendizagem (VIEIRA, 2009, p.44).
}

Neste mesmo momento histórico, instaurou-se o desafio aos gestores para lidarem com o paradoxo anunciado pela Constituição Federal, atualmente regulamentado pela Lei de Diretrizes e Bases, da expansão acelerada do acesso e a permanência dos alunos, e de se dar conta desta expansão com padrões de qualidades consideravelmente adequados.

Resultante também das novas diretrizes educacionais de 1996, a redefinição dos padrões de qualidade em educação e das expectativas de aprendizagem passa a ser uma exigência para os sistemas escolares, inclusive sobre a referência da própria LDB, em seu artigo $4^{\circ}$. Entretanto, esta busca de qualidade estaria aliada às diretrizes de eficiência e racionalização do Estado. 
A tarefa de realizar a gestão dos processos educativos e, neste caso, a gestão escolar, que nunca foi pouco complexa, a partir da década de 1990 passou a ter maiores exigências, demandas tanto da sociedade como do sistema local, nacional e internacional, e pela própria instauração de uma cultura de divulgação de índices sobre o desempenho da escola jamais visto na educação brasileira, desafios que passariam a ser colocados, seja pelos aspectos qualitativos da educação, seja pelos quantitativos, exigindo uma resposta profissional bastante complexa e integrada.

Não mais se trata de ser especializado num determinado segmento de trabalho na escola, pois, de modo geral, em muito pouco resulta ter um profissional capaz de organizar com nível de excelência os processos burocráticos institucionais, constituindo uma escola com uma organização administrativa exemplar, mas que apresente resultados pedagógicos qualitativamente pífios, muitas vezes em razão de obstáculos no trabalho pedagógico ou ainda, em um frágil projeto pedagógico relativamente visionário, que pouco contemplar as necessidades reais.

Este descolamento entre os meios pelos quais se exercita a profissionalidade e os seus fins, foi justamente a grande crítica tecida por décadas à concepção de gestão e de atuação profissional do pedagogo, que fora promulgada pelo Parecer CFE 252/69, no qual cada um que podia mais, em virtude de sua titulação, sendo que na verdade menos tinha condições de intervir na escola, em decorrência de várias exigências de especializações acerca da profissionalidade e da ausência de conhecimentos sobre todos os elementos que compõem a cultura da escola.

É patente, todavia, que a superação de uma modelo de trabalho baseado em uma suposta especialização na escola, fundamentado na compreensão do arranjo da escola pela lógica da racionalidade técnica não se consolida por imposição de dispositivos legais ou pela apresentação de políticas educacionais pontuais e transitórias.

Estas especificidades do trabalho requerem investimento em uma formação profissional dos profissionais de gestão, mais comprometida com a compreensão da escola pública e em seus dilemas e avanços na história. 
Desta forma, está vinculada à concepção de educação construída por estes profissionais, e não apenas à aquisição de conhecimentos instrumentais para a profissionalidade a qual se destinam.

Contrariamente ao que expusemos, não apenas deixar-se-á de valorizar as oportunidades e possibilidades de trabalho na escola como também correrse-á o risco de negligenciar determinados aspectos da escola, provocando a degradação do seu funcionamento administrativo, financeiro e/ou pedagógico. Por esta razão, é fundamental que as práticas de gestão escolar se organizem a partir de saberes que articulem teoria e prática, além da compreensão e da intervenção no clima da escola ${ }^{62}$.

$\mathrm{Na}$ concepção de Veiga (1998) e Hengemuhle (2004), o momento histórico em que vivemos aponta para as diretrizes educacionais dos sistemas de ensino e para o projeto pedagógico da escola. Ambos precisam ser focos do trabalho e, portanto, da profissionalidade dos gestores escolares. Por isso, é necessário adotar-se uma forma de compreensão integrada no impacto e na responsabilidade das atividades de coordenação, planejamento, orientação, administração e supervisão educacional para a melhoria dos resultados de aprendizagem das equipes e dos alunos.

Esta mudança no entendimento sobre a gestão das escolas, da organização dos procedimentos de trabalho, ou das rotinas para a regulação das ações de planejamento, implantação e acompanhamento ligados às atividades de desenvolvimento institucional confere às escolas uma situação de crise identitária, inclusive sobre seus ritos de trabalho e compreensão estabelecida às práticas burocráticas. Isto deve repercutir na metodologia de trabalho de todos os profissionais envolvidos.

Temos a indicar, pelos estudos realizados durante esta pesquisa, que a mudança das práticas de gestão influenciará decisivamente o modo de

\footnotetext{
${ }^{62}$ Em seu livro A escola como organização aprendente, Fullan e Hargreaves (2001) destacam a importância do que chamam de clima escolar, ou seja, das construções e relações que se intercambiam através das práticas profissionais, na construção de um ambiente mais propício para a aprendizagem colaborativa dos profissionais ou para a formação de alternativas de organização dos segmentos mais compartimentados, obstruindo a melhoria institucional e a possibilidade da escola desenvolver-se de forma mais total.
} 
organização da escola, que poderá transitar de uma tendência científicoracional ou autogestionária para outras possíveis tendências como a interpretativa ou a democrático-participativa.

Como resultado, poderá produzir uma concepção sócio-crítica sobre a profissionalidade dos pedagogos que atuam na escola, exigindo intelectualidade, ou estaremos fadados a uma atuação meramente tecnocrática, revestida de uma pseudo autonomia, como também advertem Libâneo, Oliveira e Toschi (2005), ao afirmarem que

Há, pelo menos, duas maneiras de ver a gestão educacional centrada na escola. Na perspectiva neoliberal, pôr a escola como centro das políticas significa liberar boa parte das responsabilidades do Estado, deixando às comunidades e às escolas a iniciativa de planejar, organizar e avaliar os serviços educacionais. Já na perspectiva sociocrática, a decisão significa valorizar as ações concretas dos profissionais na escola que sejam decorrentes de sua iniciativa, de seus interesses, de suas interações (autonomia e participação), em razão do interesse público dos serviços educacionais prestados, sem com isso, desobrigar o Estado de suas responsabilidades. (LIBÂNEO; OLIVEIRA; TOSCHI, 2005, p. 295)

Os próprios sistemas de ensino, ao determinarem o perfil dos gestores escolares para o provimento de cargos em suas estruturas, quando da realização de concursos públicos ou processos seletivos, procuram relacionar um conjunto de competências ${ }^{63}$ que devem portar para o exercício mais eficaz

\footnotetext{
${ }^{63}$ Embora estejamos distantes da anuência de muitos pesquisadores do campo da educação no que se refere ao "conceito de competência" relacionado à formação e à atuação dos professores e dos demais profissionais do magistério, tomados este conceito por referencia, ao concordar com as Rué (2009), que apresenta a competência como um processo de formação centrado na pessoa, em suas capacidades, possibilidades de formação e na compreensão de seu contexto. Aproximamo-nos, portanto, do conceito de competência mais presente nas abordagens realizadas na Alemanha, que entendem o desenvolvimento das capacidades dos profissionais de forma ecológica e globalizadora, ou mesmo dos estudos realizados no Reino Unido, que concebem as competências como capacidades integradas entre si, e diferentemente de americanos que aproximam este conceito da maior especialização do sujeito. Todavia, as ponderações de Almeida (2009), embora combativa ao conceito de competência, também nos alertam para o risco da tomada deste conceito como slogan de políticas educacionais descontinuadas que apenas expropriam os professores de suas capacidades de construção de conhecimento, abstraindo-os da realidade do campo de trabalho.
} 
do seu trabalho; o que indica que tais atributos necessários para esta qualidade profissional também decorrem da formação inicial dos pedagogos.

Demonstraremos, no quadro a seguir, as competências previstas para os egressos do curso de Pedagogia e as desejadas no perfil dos gestores escolares, trazendo, como exemplo, os casos previstos nos dispositivos legais da Secretaria de Estado da Educação de São Paulo, na circunstância do provimento de tais cargos ou funções, tendo em vista a abrangência da rede pública estadual.

Neste quadro, a proposta é identificar criticamente as eventuais relações entre as competências previstas para os egressos dos cursos de Pedagogia, e as capacidades e habilidades sugeridas como fundamentais, não apenas para o provimento de cargos ou funções de gestão escolar, mas para o desenvolvimento da profissionalidade destes profissionais, diante de objetivos assinalados pelas atuais políticas educacionais dos sistemas, como segue: 


\section{Análise comparativa: Competências dos egressos do curso de Pedagogia e competências dos gestores da Rede Estadual de São Paulo}

\begin{tabular}{|c|c|c|c|c|c|c|c|c|c|c|c|}
\hline Competências para Gestores da SEE SP & $\begin{array}{l}\text { Competências } \\
\text { Supervisor de Ensino } \\
\text { (Resolução SE 70/10) }\end{array}$ & S1 & S2 & S3 & S4 & S5 & S6 & S7 & S8 & s9 & $\mathrm{S} 10$ \\
\hline \multirow{2}{*}{$\begin{array}{l}\text { Competências para os egressos do curso de Pedagogia } \\
\text { (Resolução CNE CP 01/06, artigo } 5^{\circ} \text { ) }\end{array}$} & $\begin{array}{l}\text { Competências } \\
\text { Diretor de Escola } \\
\text { (Resolução SE 70/10 } 0^{64} \text { ) }\end{array}$ & D1 & D2 & D3 & D4 & D5 & D6 & D7 & D8 & D9 & D10 \\
\hline & $\begin{array}{l}\text { Competências } \\
\text { Professor Coordenador } \\
\text { Pedagógico (Resolução } \\
\text { SE 88/07) }\end{array}$ & $\begin{array}{c}\text { PCP } \\
1\end{array}$ & $\begin{array}{l}\mathrm{PCP} \\
2\end{array}$ & $\begin{array}{c}\mathrm{PCP} \\
3\end{array}$ & $\begin{array}{c}\text { PCP } \\
4\end{array}$ & $\begin{array}{l}\mathrm{PCP} \\
5\end{array}$ & $\begin{array}{l}\text { PCP } \\
6\end{array}$ & $\begin{array}{l}\text { PCP } \\
7\end{array}$ & & & \\
\hline $\begin{array}{l}\text { I - atuar com ética e compromisso com vistas à construção de uma } \\
\text { sociedade justa, equânime, igualitária; }\end{array}$ & & $\begin{array}{l}\mathbf{X} \\
\mathbf{X}\end{array}$ & & & $X$ & & & & & & \\
\hline \multicolumn{12}{|l|}{$\begin{array}{l}\text { II - compreender, cuidar e educar crianças de zero a cinco anos, de } \\
\text { forma a contribuir, para o seu desenvolvimento nas dimensões, entre } \\
\text { outras, física, psicológica, intelectual, social; }\end{array}$} \\
\hline $\begin{array}{l}\text { III - fortalecer o desenvolvimento e as aprendizagens de crianças do } \\
\text { Ensino Fundamental, assim como daqueles que não tiveram } \\
\text { oportunidade de escolarização na idade própria; }\end{array}$ & & $x$ & & & & $\begin{array}{l}\mathbf{X} \\
\mathbf{X}\end{array}$ & & & & & \\
\hline $\begin{array}{l}\text { IV - trabalhar, em espaços escolares e não-escolares, na promoção da } \\
\text { aprendizagem de sujeitos em diferentes fases do desenvolvimento } \\
\text { humano, em diversos níveis e modalidades do processo educativo; }\end{array}$ & & & & $X$ & & $\begin{array}{l}\mathbf{X} \\
\mathbf{X} \\
\mathbf{X}\end{array}$ & & & $\begin{array}{l}\mathbf{X} \\
\mathbf{X}\end{array}$ & & \\
\hline
\end{tabular}

\footnotetext{
${ }^{64}$ A Resolução SE 70/10 foi substituída pela Resolução SE 52/13, sobretudo para a atualização do referencial bibliográfico que orienta o perfil dos gestores para concursos e processos seletivos na rede estadual de São Paulo, mas mantendo proposta semelhante na disposição de competências e habilidades desejadas, o que nos permite considerá-la como instrumento de referência para a análise comparativa a que nos propusemos.
} 


\begin{tabular}{|c|c|c|c|c|c|c|c|c|c|c|}
\hline $\begin{array}{l}\text { V - reconhecer e respeitar as manifestações e necessidades físicas, } \\
\text { cognitivas, emocionais, afetivas dos educandos nas suas relações } \\
\text { individuais e coletivas; }\end{array}$ & $\begin{array}{l}\mathbf{X} \\
\mathbf{X}\end{array}$ & & & & & $X$ & & & & \\
\hline \multicolumn{11}{|l|}{$\begin{array}{l}\text { VI - ensinar Língua Portuguesa, Matemática, Ciências, História, } \\
\text { Geografia, Artes, Educação Física, de forma interdisciplinar e adequada } \\
\text { às diferentes fases do desenvolvimento humano; }\end{array}$} \\
\hline $\begin{array}{l}\text { VII - relacionar as linguagens dos meios de comunicação à educação, } \\
\text { nos processos didático-pedagógicos, demonstrando domínio das } \\
\text { tecnologias de informação e comunicação adequadas ao } \\
\text { desenvolvimento de aprendizagens significativas; }\end{array}$ & & $\begin{array}{l}\mathbf{X} \\
\mathbf{X}\end{array}$ & $X$ & & $\begin{array}{l}\mathbf{X} \\
\mathbf{X}\end{array}$ & & $X$ & $\begin{array}{l}\mathbf{X} \\
\mathbf{X}\end{array}$ & & \\
\hline $\begin{array}{l}\text { VIII - promover e facilitar relações de cooperação entre a instituição } \\
\text { educativa, a família e a comunidade; }\end{array}$ & & & $\begin{array}{l}X \\
X\end{array}$ & & $X$ & & & $X$ & & \\
\hline $\begin{array}{l}\text { IX - identificar problemas socioculturais e educacionais com postura } \\
\text { investigativa, integrativa e propositiva em face de realidades complexas, } \\
\text { com vistas a contribuir para a superação de exclusões sociais, étnico- } \\
\text { raciais, econômicas, culturais, religiosas, políticas e outras; }\end{array}$ & $\begin{array}{l}\mathbf{X} \\
\mathbf{X}\end{array}$ & & & $\begin{array}{l}\mathbf{X} \\
\mathbf{X}\end{array}$ & $X$ & & & $\begin{array}{l}\mathbf{X} \\
\mathbf{X}\end{array}$ & & \\
\hline $\begin{array}{l}\text { X - demonstrar consciência da diversidade, respeitando as diferenças de } \\
\text { natureza ambiental-ecológica, étnico-racial, de gêneros, faixas } \\
\text { geracionais, classes sociais, religiões, necessidades especiais, escolhas } \\
\text { sexuais, entre outras; }\end{array}$ & $\begin{array}{l}\mathbf{X} \\
\mathbf{X}\end{array}$ & & & & & $X$ & & & & \\
\hline $\begin{array}{l}\mathrm{XI} \text { - desenvolver trabalho em equipe, estabelecendo diálogo entre a área } \\
\text { educacional e as demais áreas do conhecimento; }\end{array}$ & & $X$ & $X$ & $X$ & & & & $\begin{array}{l}\mathrm{X} \\
\mathrm{X}\end{array}$ & $\begin{array}{l}\mathrm{X} \\
\mathrm{X}\end{array}$ & $\begin{array}{l}\mathbf{X} \\
\mathrm{X}\end{array}$ \\
\hline $\begin{array}{l}\text { XII - participar da gestão das instituições contribuindo para elaboração, } \\
\text { implementação, coordenação, acompanhamento e avaliação do projeto } \\
\text { pedagógico; }\end{array}$ & $X$ & $X$ & $\begin{array}{l}\mathrm{X} \\
\mathrm{X} \\
\mathrm{X}\end{array}$ & $X$ & $\begin{array}{l}\mathbf{X} \\
\mathbf{X}\end{array}$ & $\begin{array}{l}\mathbf{X} \\
\mathbf{X}\end{array}$ & $\begin{array}{l}\mathbf{X} \\
\mathbf{X}\end{array}$ & $\begin{array}{l}\mathbf{X} \\
\mathbf{X}\end{array}$ & $\begin{array}{l}X \\
X\end{array}$ & \\
\hline $\begin{array}{l}\text { XIII - participar da gestão das instituições planejando, executando, } \\
\text { acompanhando e avaliando projetos e programas educacionais, em } \\
\text { ambientes escolares e não-escolares; }\end{array}$ & $X$ & $X$ & $\begin{array}{l}X \\
X\end{array}$ & $X$ & $\begin{array}{l}\mathbf{X} \\
\mathbf{X}\end{array}$ & $\begin{array}{l}X \\
X\end{array}$ & $\begin{array}{l}X \\
X\end{array}$ & $\begin{array}{l}X \\
X\end{array}$ & $\begin{array}{l}X \\
X\end{array}$ & \\
\hline $\begin{array}{l}\text { XIV - realizar pesquisas que proporcionem conhecimentos, entre outros: } \\
\text { sobre alunos e alunas e a realidade sociocultural em que estes } \\
\text { desenvolvem suas experiências não escolares; sobre processos de } \\
\text { ensinar e de aprender, em diferentes meios ambiental- ecológicos; sobre } \\
\text { propostas curriculares; e sobre organização do trabalho educativo e } \\
\text { práticas pedagógicas; }\end{array}$ & & $X$ & $\begin{array}{l}X \\
X\end{array}$ & $X$ & $\begin{array}{l}X \\
X \\
X\end{array}$ & $\begin{array}{l}X \\
X\end{array}$ & $\begin{array}{l}\mathbf{X} \\
\mathbf{X}\end{array}$ & $\begin{array}{l}X \\
X\end{array}$ & $\begin{array}{l}X \\
X\end{array}$ & $\begin{array}{l}x \\
X\end{array}$ \\
\hline
\end{tabular}




\begin{tabular}{|c|c|c|c|c|c|c|c|c|c|c|}
\hline $\begin{array}{l}\text { XV - utilizar, com propriedade, instrumentos próprios para construção de } \\
\text { conhecimentos pedagógicos e científicos; }\end{array}$ & & $\begin{array}{l}X \\
X \\
X\end{array}$ & & & $X$ & $\begin{array}{l}\mathbf{x} \\
\mathbf{x}\end{array}$ & $\begin{array}{l}X \\
X \\
X\end{array}$ & $\begin{array}{l}\mathbf{x} \\
\mathbf{x}\end{array}$ & $\begin{array}{l}\mathbf{x} \\
\mathbf{x}\end{array}$ & \\
\hline $\begin{array}{l}\mathrm{XVI} \text { - estudar, aplicar criticamente as diretrizes curriculares e outras } \\
\text { determinações legais que lhe caiba implantar, executar, avaliar e } \\
\text { encaminhar o resultado de sua avaliação às instâncias competentes. }\end{array}$ & $\mathbf{x}$ & X & $\begin{array}{l}\mathbf{X} \\
\mathbf{X}\end{array}$ & $x$ & $\begin{array}{l}\mathbf{X} \\
\mathbf{X}\end{array}$ & $\begin{array}{l}X \\
X \\
X\end{array}$ & $\begin{array}{l}\mathbf{x} \\
\mathbf{x}\end{array}$ & & $\begin{array}{l}\mathbf{X} \\
\mathbf{x}\end{array}$ & $\begin{array}{l}\mathbf{x} \\
\mathbf{x}\end{array}$ \\
\hline
\end{tabular}


Como antecipamos, o instrumento construído se destina à análise comparativa das competências apontadas como marcos de aprendizagem para os egressos do curso de Pedagogia, referindo-se ao conjunto de habilidades profissionais aos quais os concluintes devem dominar para atuarem, e comparativamente as competências apontadas como fundamentais pela Secretaria de Estado da Educação de São Paulo ${ }^{65}$, para os gestores que ocupam estas as funções de Supervisor de Ensino, Diretor de Escola e Professor Coordenador Pedagógico na rede estadual.

Embora esta análise se refira especificamente a comparação entre a matriz formativa dos gestores escolares no curso de Pedagogia e o perfil desejado para os que atuam na rede estadual paulista, pode ser considerada uma tendência no processo de formação e atuação de tais pedagogos, sobretudo pela influência que o modelo de organização do sistema estadual empreende sobre os sistemas municipais do estado de São Paulo, além da semelhança de organização em outros sistemas de ensino estaduais.

Esta análise, portanto, destina-se a ajuizar em que medida o perfil profissional desejado aos profissionais que ingressarão nas atividades de gestão escolar e educacional, e principalmente das escolas, encontram possibilidades de aquisição ou apropriação (previsão legal) de conhecimentos e habilidades nos cursos de formação inicial em Pedagogia, e que em tese, devem "habilitá-los" para tal atuação profissional neste campo do magistério, considerando sua profissionalidade.

Um primeiro aspecto relevante é que notamos intensa articulação entre as competências apresentadas como desejáveis aos egressos do curso de Pedagogia e os saberes requeridos aos profissionais responsáveis pela gestão nas escolas da rede estadual, ou por outros sistemas.

\footnotetext{
${ }^{65}$ As matrizes de competência estabelecidas pela Secretaria de Estado da Educação de São Paulo se apóiam no caso de Professores Coordenadores Pedagógicos, na Resolução SE 88/07, e no caso de Diretores de Escola e Supervisores de Ensino, inicialmente na Resolução SE 70/10, e posteriormente na Resolução SE 53/12. Ambos dispositivos legais que subsidiaram a coleta destes dados e a presente análise, constam dos anexos desta tese.
} 
Se por um lado, este fato apresenta considerável coerência no que se propõe, ao menos em tese, como base formativa; por outro, representa também que a abordagem enfaticamente destinada a alguns aspectos, como a gestão de resultados ou a otimização de recursos traz em si uma concepção própria de gestão escolar e sobre a própria educação, enfatizando excessivamente o trabalho voltado para o alcance de resultados, de superação de metas, de formas mais eficazes de lidar com instrumentos de avaliação, podendo inclusive desvirtuar o papel da avaliação na (e para) a escola.

Outro aspecto que destacaríamos é que tanto nas competências elencadas pelas diretrizes do curso de Pedagogia, quanto nas competências requeridas pela Secretaria de Estado da Educação de São Paulo para os profissionais da gestão, há foco na dimensão pedagógica do trabalho.

Todavia, a indistinção mais clara sobre o que cabe a cada um dos profissionais, seja na coordenação, na administração ou na supervisão, ou mesmo orientação educacional (quando houver), pode dilatar a indefinição do que é propriedade mais específica do campo de atuação de cada um dos ofícios do pedagogo na escola, em que pese seus aspectos de convergência, como se tudo coubesse a todos ao mesmo tempo na escola.

Esta condição pode aprofundar o processo de perda de identidade profissional daqueles que atuam em aspectos relativamente específicos em determinadas situações pedagógicas, educativas e institucionais, mesmo porque, tal condição não se supera apenas com a extinção de "habilitações de curso", mas com outra forma de propositura para a formação e o desenvolvimento destes profissionais, enfrentando-se a realidade na qual, poucos sabem o que tem e como devem fazer, há uma grande tendência de repetirem os modelos com os quais tiveram contato ou indícios.

Não se trata apenas da abolição das habilitações, fato já concretizado legalmente, para que possamos construir uma forma sócio-crítica de gestão, ainda que tal medida possa ter trazido algumas contribuições, o fato é a melhoria da profissionalização dos gestores escolares, de maneira que mesmo aprofundando seus conhecimentos em determinados ofícios a serem 
desempenhados na escola, estejam intimamente ligados pela essência pedagógica do que tem a ser feito.

A esse respeito, Libâneo, Oliveira e Toschi (2005) corroboram as nossas considerações acerca da importância do projeto pedagógico da escola pública no Brasil, da organização coletiva da equipe escolar, da prática profissional colaborativa, e da consciência acerca das intencionalidades do trabalho, sobretudo, do trabalho de gestão na escola:

\begin{abstract}
Uma visão sociocritica propõe compreender dois aspectos interligados: de um lado, a organização como uma construção social envolvendo a experiência subjetiva e cultural das pessoas; de outro, essa construção não como um processo livre e voluntário, mas mediatizado pela realidade sociocultural e política mais ampla, incluindo a influência de forças externas e internas marcadas por interesses de grupos sociais sempre contraditórios e, às vezes, conflituosos. Tal visão busca relações solidárias, formas participativas, mas também valoriza os elementos internos do processo organizacional - o planejamento, a organização, a gestão, a direção, a avaliação, as responsabilidades individuais dos membros da equipe e a ação organizacional coordenada e supervisionada, já que esta precisa atender a objetivos sociais e políticos muito claros, relativos à escolarização da população. (LIBÂNEO; OLIVEIRA; TOSCHI, 2005, p. 323)
\end{abstract}

A leitura comparativa dos dispositivos legais também indica que embora existam competências que se referem ao conhecimento sobre diretrizes gerais da educação, sobre a articulação entre a escola, a comunidade e outras instâncias de sistema, presumindo que os gestores sejam competentes para lidar com os desafios das linguagens ou das relações, principalmente quando nos aproximamos das competências específicas.

Entretanto, estas competências apresentadas não evidenciam o desenvolvimento de capacidades que tenham vínculo mais contundentemente político, ou que se posicionem como sujeitos intelectuais responsáveis pela tomada de decisão ou conferência de poder, o que pode aludir a uma função mais voltada a procedimentos técnicos, ainda que os pressupostos iniciais sejam voltados para objetivos e metas pedagógicas, o que implica em risco de uma qualidade profissional controlável e ilusória.

Observa-se também que mesmo nas competências gerais para os profissionais da gestão, não há menção mais específica ou direta às questões 
de ensino, a exceção da proposta de se considerar a capacidade de compreensão e inferência sobre as diretrizes curriculares ou sobre a proposta curricular apresentada pela rede.

Tal abordagem de competências pelos sistemas destina mais enfaticamente o domínio da capacidade de ensino aos docentes, correndo-se o risco, a nosso ver, de fragmentar o que é ensinar, o que é saber, garantir aprendizagem e ser competente para organizar e desenvolver processos educativos institucionais, como se fossem situações dissociadas na escola.

Percebe-se também pela análise das competências apresentadas como fundamentais aos egressos do curso de Pedagogia que há uma relação muito próxima entre a matriz de competências do curso de Pedagogia para os profissionais a serem formados e as competências desejadas pelo sistema de ensino estadual paulista.

No entanto, ao analisarmos as matrizes curriculares dos cursos de Pedagogia, detectamos um espaço formativo pouco expressivo na maioria dos casos que nos serviram de base para discussão, como aprofundaremos adiante na análise do que apresentam mais especificamente as matrizes curriculares dos cursos.

Esta análise comparativa sobre a formação superior e o que é exigido dos profissionais que atuam nas atividades de gestão, demonstra que existe uma ênfase paradoxal em dois extremos no que se refere ao exercício profissional: o discurso do desenvolvimento de competências, mas a ênfase em aspectos mais pragmáticos do trabalho, requerendo quase que tão somente aquisição de habilidades.

Este paradoxo fica ainda mais evidente quando nos reportamos à profissionalidade dos gestores ao lidar com: gestão de resultados a partir de instrumentos e sistemas avaliativos, gestão de diretrizes gerais da educação e legislação principalmente aplicadas ao projeto pedagógico, gestão do currículo e dos processos de aprendizagem, e gestão de pessoas em suas relações e 
conflitos. Ou seja, todos estes profissionais podem atuar no sentido de garantir a atividade essencial do projeto pedagógico das escola: a aprendizagem?

Há, portanto um destaque aos aspectos de macro funcionamento da escola, o que nem sempre é elemento determinante para o alcance de uma escola e de uma educação de qualidade, já que esta qualidade para ser alcançada não pode prescindir de ações locais de decisão, de atuação política dos gestores, de autonomia para a tomada de decisões e desenvolvimento de práticas institucionais que evidenciem a cultura da escola e em seu projeto pedagógico.

Este projeto pedagógico deve ser tomado como instrumento de construção colaborativa das equipes locais e não apenas da cultura escolar socialmente difundida. O que implica em projetos de formação de tais profissionais que se voltem para esta concepção de formação de gestão, ou que as competências já estabelecidas pelos dispositivos legais dêem o tom de tal concepção mais emancipatória e intelectual, afastando-se de uma atuação mais tecnocrática.

As evidências que apresentamos sobre o perfil dos egressos do curso de Pedagogia, e o que é esperado pelos sistemas de ensino, tomando a rede estadual de São Paulo como base, se reafirma não apenas pelo que os dispositivos legais da rede estadual apresentam como competências gerais esperadas dos profissionais da gestão no magistério, mas também quando se analisa o conjunto de habilidades e capacidades, chamadas de "habilidades específicas" destinadas aos ofícios de Diretor de Escola e Supervisor de Ensino.

Mais detalhadamente, no caso de Diretor de Escola, onde estão previstas vinte e uma destas capacidades específicas para os pedagogos que exercem este ofício, pudemos classificar que de modo geral: sete estão vinculadas à gestão de resultados e processos de avaliação; sete à gestão de diretrizes e política educacional e sistema legal; duas se voltam mais especificamente à gestão do currículo; três priorizam gestão de pessoas; e 
outras duas competências se referem ao plano de trabalho do diretor e às ações de formação continuada para os profissionais da escola e para si.

Já no caso dos Supervisores de Ensino, onde estão previstas vinte e três competências específicas para os pedagogos que atuarão neste ofício, pudemos chegar aos seguintes dados: oito estão vinculadas à gestão de resultados e processos de avaliação; sete à gestão de diretrizes e política educacional e sistema legal; três que se voltam mais especificamente à gestão do currículo: uma prioriza gestão de pessoas; e outras quatro competências se referem ao plano de trabalho do supervisor, a ação supervisora e a ações de formação continuada para a equipe de supervisão de ensino.

Habilidades Específicas para cargos de Diretor e Supervisor (*)

\begin{tabular}{|c|c|c|}
\hline $\begin{array}{l}\text { Habilidades para o Diretor } \\
\text { de Escola }\end{array}$ & $\begin{array}{l}\text { Campo das Habilidades } \\
\text { Específicas exigidas }\end{array}$ & $\begin{array}{l}\text { Habilidades para o } \\
\text { Supervisor de Ensino }\end{array}$ \\
\hline $10,11,12$ e 15 & $\begin{array}{l}\text { Relações Humanas e } \\
\text { Comunitárias }\end{array}$ & 12 \\
\hline $1,4,5,6,8$ e 16 & $\begin{array}{l}\text { Currículo, Conhecimento e } \\
\text { Aprendizagem }\end{array}$ & $1,5,6,13$ e 14 \\
\hline $2,3,4,6,8,9$ e 14 & $\begin{array}{l}\text { Políticas Públicas, } \\
\text { Legislação e Normas }\end{array}$ & $2,3,4,6,8,9$ e 10 \\
\hline $6,7,13,14,17,18,19$ e 20 & $\begin{array}{c}\text { Avaliação e Indicadores de } \\
\text { Desempenho }\end{array}$ & $6,7,11,15,16,17,18$ e 19 \\
\hline 13 & $\begin{array}{c}\text { Profissão, Formação } \\
\text { Contínua e } \\
\text { Profissionalização }\end{array}$ & $6,20,21$ e 22 \\
\hline
\end{tabular}

(*) Conjunto de habilidades específicas estabelecidas para o exercício dos cargos de Diretor de Escola e Supervisor de Ensino da rede estadual paulista, conforme a Resolução SE 70/10, como segue no anexo II deste trabalho.

A análise do quadro apresentado demonstra que há um intenso destaque para as habilidades que se referem ao trabalho destinado às práticas avaliativas, à análise de indicadores e resultados, ao atendimento de políticas públicas educacionais e sua implementação, corroborando a perspectiva de 
gestão que já apontamos marcante no discurso educacional contemporâneo, e que se aproxima de metodologias mais eficientes de melhoria de desempenho.

Identificamos que competências relacionadas à gestão de resultados avaliativos; implementação de projetos e de práticas baseadas em experiências metodológicas inovadoras; organização e mediação nas situações e espaços destinados à formação profissional docente; atividades de articulação entre a comunidade e a escola; e, finalmente, processos de melhoria do desenvolvimento da aprendizagem e institucionais são destacados no perfil previsto para estes profissionais, segundo a SEE SP, e que convergem com os marcos de aprendizagens para os egressos da Pedagogia, segundo as Diretrizes Curriculares Nacionais para o Curso de Pedagogia.

Entretanto, no caso de Diretores como de Supervisores há um destaque menos significativo nas habilidades necessárias para as práticas de gestão de pessoas ou das ações de profissionalização dos profissionais da educação, e mais precisamente da escola, o que vai de encontro à melhoria dos resultados e da qualidade da educação, uma vez que para que isto aconteça precisamos de profissionais que tenham melhor formação ${ }^{66}$, e que esta tenha sentido com seus contextos de trabalho, numa profissionalização significativa.

Notamos ainda que embora exista a ênfase nas questões relacionadas à avaliação da aprendizagem, institucional e sistema, e aos indicadores de avaliação; questões curriculares, ou ainda políticas públicas, os percursos formativos que tomamos como corpus desta pesquisa demonstram que nem

\footnotetext{
${ }^{66}$ No trabalho apresentado na ANPED, em 2010, "Desenvolvimento profissional docente: uma atribuição que também é do sindicato", Maria Isabel de Almeida traz contribuições muito relevantes para a discussão do processo de profissionalização dos professores, destacando que este é um processo que precisa ocorrer para além dos muros da escola, e que deve levar em conta as possibilidades de articulação dos professores pelas suas reivindicações profissionais de diferentes naturezas. É importante destacar que a prática da reivindicação das categorias profissionais também pode ser reconhecida como uma forma de construção de sua identidade social, tecida a partir dos encontros entre aqueles que partilham de dilemas, conflitos, compreensões, necessidades e conquistas a serem socializadas, seja para sua apropriação crítica, seja para a superação. Portanto, o sindicato não é tomado apenas como espaço de lutas pela carreira, apesar de dever ser um foco, mas também de causas tão relevantes quanto, como o debate ideológico, pedagógico e intelectual, logo de intensa profissionalização.
} 
mesmo estes conteúdos têm recebido tal prioridade na formação dos pedagogos, quando muito sendo propostos fragmentada ou isoladamente, como trataremos detalhadamente no capítulo III do trabalho, ao analisar o perfil anunciado pelos sistemas e profissionais e o proposto pelos currículos dos cursos.

Observamos, pela relação entre as competências da formação do pedagogo e as competências esperadas para os gestores da rede estadual, que há o atendimento de determinadas demandas estabelecidas pelo próprio sistema estadual paulista, ao menos no que se referem à proposta formativa das diretrizes. Existem entre ambas - as diretrizes e os referenciais legais do sistema estadual, inúmeras correspondências indicando o esperado sobre a atuação dos gestores escolares, que não se restringem à resolução de questões técnicas ou procedimentos administrativos.

Ao realizar-se uma análise mais pormenorizada, podemos notar que as competências esperadas dos gestores escolares são diretamente relacionadas aos pressupostos legais próprios das diretrizes curriculares da Pedagogia ou ao perfil desejado pelo sistema estadual, não havendo maior destaque para o projeto pedagógico da instituição.

Por outro lado, a escola não é apenas uma instituição reprodutivista, mas também é o espaço onde, através da práxis profissional, se constroem relações de poder; por consequência, confrontam-se lógicas que orientarão os modelos de gestão do sistema e as perspectivas educativas de tais instituições, optando-se pela ruptura entre planejamento e execução do sentido intelectual da escola ou pelo enfrentamento de modos de organização essencialmente baseados no burocratismo ${ }^{67}$.

A fragmentação que se faz presente no campo da educação, não se trata apenas de um fracionamento técnico que existe na realização do trabalho, mas também da impregnação do valor de capital e de uma forma extenuante

\footnotetext{
${ }^{67}$ Sobre a lógica burocrática do trabalho na escola, Monica Gather Thurler (2001) destaca com propriedade o impacto desta concepção de organização do trabalho sobre o clima da escola, e sobre o impedimento constituído acerca das possibilidades da escola se desenvolver como instituição aprendente, em suas diferentes zonas de trabalho.
} 
de obrigação de envolvimento e dedicação dos profissionais para a realização do mesmo (KUENZER, 2003).

Esta lógica de proposta de formação dos gestores escolares e de pensar a forma de atuarem nas escolas, está relacionada diretamente à fragmentação ou multitarefa que determina o fazer: à automação ou autonomia pela qual é realizada e à padronização ou criatividade que se caracterizam como estratégias sociológicas determinantes na profissionalidade, inclusive dos pedagogos, características que resultam da divisão do conhecimento profissional, o que não se resolve apenas com o discurso do desenvolvimento de competências, que podem servir apenas como habilidades a priori desvinculadas da intelectualidade crítica e emancipatória.

Em razão deste contexto de crise identitária e de construção de distintas formas de trabalho, Hengemuhle (2004) defende que são construídos outros significados para a instituição escolar e para a atividade de seus profissionais, assim como para seus processos de trabalho e para os ofícios que na escola são praticados.

Este fato implica, inclusive, em se desenvolver outras propostas de formação e profissionalização diante de outras necessidades que se apresentam para atuar, como cita:

\footnotetext{
As crises desestabilizam as pessoas e as instituições. No entanto, diante dos contextos e do desejo humano de buscar respostas, se as crises forem bem administradas, individual e coletivamente, possibilitam reconstruções e avanços significativos. É muito difícil dar crédito a pessoas, ou instituições que, aparentemente, estão vivendo em calmaria, pois isso é um sinal de comodidade e falta de criatividade para inovar. Tais pessoas, ou tais instituições preferem dar as costas ao mundo e fazer de conta que tudo está bem (HENGEMUHLE, 2004, p.168).
}

A proposição apresentada pelo autor, assim como os elementos sobre a perspectiva de gestão, que defendemos e apontamos até agora, legitima a construção de uma organização para o trabalho na escola pública, que não se sustenta pela lógica da profissionalidade baseada no trabalho dos 
"especialismos" profissionais, que supostamente atuariam isoladamente em segmentos organizativos da escola, ou fora dela, em se tratando de sua regulação.

Não se trata de afirmar que os especialistas pouco colaboraram para a mudança da escola, até porque, não deixaram de existir ou foram transformados, mas que esta maneira de atuar pode alcançar determinadas melhorias de resultados pela atuação em segmentos de trabalho mais isolados, mas dificilmente o desenvolvimento institucional proveniente da articulação das várias atividades, para que se alcance objetivos e metas colaborativamente definidos e vinculados aos contextos reais da prática.

Acreditamos que as atividades de gestão, como forma de suporte à atividade pedagógica e à docência, reconhecem que, embora exista distinção entre os fazeres escolares, não deve haver consagração da ruptura dissociativa do que substancialmente precisa orientar a sua profissionalidade.

Quanto a isto, deve-se ter consciência de que a atuação de planejamento, administração, coordenação ou supervisão precisam priorizar o desenvolvimento pedagógico, o qual deve ser o eixo orientador das práticas escolares. Neste sentido, Libâneo (2004) destaca que,

(...) a organização escolar necessária é aquela que assegura os meios mais eficazes para atender os objetivos e funções da escola. Nesse sentido, acreditamos que a principal razão para que as escolas sejam mais bem organizadas e administradas é a melhoria da qualidade das aprendizagens escolares dos alunos. Ou seja, uma escola bem organizada e gerida, é aquela que cria e assegura as melhores condições organizacionais, operacionais e pedagógicas de desempenho profissional dos professores, de modo que os seus alunos tenham efetivas possibilidades de serem bem-sucedidos em suas aprendizagens (LIBÂNEO, 2004, p.263).

A tarefa de garantir esta aprendizagem não é algo que se restringe ao trabalho apenas dos professores, assim implica na articulação entre a construção do pensamento pedagógico e o seu desenvolvimento na ação prática do fazê-lo, querendo afirmar que: para docentes ou gestores a prioridade do trabalho deve ser a aprendizagem. 
Afirmamos, ainda, que o professor ao projetar as suas aulas, precisa administrá-las durante o exercício da docência; do mesmo modo, o diretor deve realizar a supervisão da dimensão pedagógica em sua escola, assim como supervisão demanda visão coordenada sobre a escola. Assim, torna-se condição sine qua non que o coordenador administre as ações, espaços e tempos, por exemplo, de formação profissional nos horários próprios a que se destina na escola; cabendo ainda aos profissionais, que se dedicam à supervisão, a orientação e acompanhamento da implantação do projeto da escola, observadas as regulamentações do sistema.

Consideramos, por esta congruência entre as atividades, que todas se baseiem na realização da docência, como fonte primária de ofício na relação educativa de ensino e aprendizagem, de conhecimento e de investigação, sem desprezar o caráter epistemológico da pesquisa, que reveste a ciência da educação.

Esta é a premissa que nos leva a destacar novamente que não há sentido a ser atribuído aos ofícios relacionados à gestão escolar, senão quando estão comprometidos e compromissados com o dever da escola que é o de ensinar e, portanto, de destinar as atividades profissionais distintas em campos de atuação mais congruentes na finalidade de que os protagonistas aprendam naquela instituição.

Destarte, os saberes que orientam os fazeres dos gestores escolares precisam ser profundamente pedagógicos no seu campo de atuação, embora esta dimensão pedagógica não prescinda da competência técnica inerente a cada ofício. Tais saberes pedagógicos são a razão de ser da escola e do processo educativo, ou seja, mais significativos do que habilidades essencialmente especializadas, sob o risco de distanciarmo-nos da confluência necessária para os mesmos objetivos, como Silva Jr. (2003) alertara que,

Foi a busca da substancialidade própria da administração que de alguma forma a afastou do ensino. Em busca de sua identidade a administração escolar, e por extensão, a supervisão afastaram-se do ensino para não serem com ele confundidos. A procura teórica freqüentemente deu origem a distância pessoal: como "administrador 
ou supervisor não me cabe pensar as situações de sala de aula. "Como" professores não cabe a "eles" pensar os problemas da administração. Logo, "como" supervisor, meu interlocutor "natural" e exclusivo na escola será o diretor, aquele que não se ocupa do trabalho docente (SILVA, 2003, p.105).

Portanto, não se trata apenas de substituir a nomenclatura de especialistas para gestores, como se a mudança se concretizasse apenas por alteração semântica. É fundamental a mudança do paradigma, no qual se assenta a profissionalidade destes profissionais, e a concepção teórica, que sustenta e orienta esta forma de atuação e de atribuição de sentido democrático à escola e à educação.

Transformar os modos e o sentido do trabalho em gestão escolar tem a ver com profissionalização, e uma profissionalização de pedagogos para que sejam criticamente capazes de lidar com os diferentes segmentos da organização do trabalho escolar, que politicamente conscientes e críticos, refletem sobre seu contexto e condições de trabalho, de modo que se pautem em atitudes mediadas pela ética.

O conceito de especialistas em educação, além de reafirmar a ideologia de que as atividades se organizam de forma estratificada, fortalece e reafirma a idéia da responsabilidade do outro, uma vez que cada um, supostamente, detém o monopólio do saber sobre os conhecimentos de determinadas atividades pedagógicas na escola. Esta perspectiva reforça a lógica da responsabilidade e da competência profissional individualista, contrapondo-se às propostas colaborativas de desenvolvimento institucional.

Ao apontarmos este esgotamento da concepção de especialistas, alertamos para a ilusão provocada pelo fato de que haver outra nomenclatura seria suficiente para o surgimento de outras formas de trabalho, como antecipamos. Contudo, reafirmamos, não o é, pois tratamos não apenas de especialistas, mas de superar os especialismos profissionais.

Conseqüentemente, não basta a substituição de terminologias sobre a organização da escola ou seus profissionais, mas a construção de uma cultura mais participativa, criativa, comprometida com a mudança que é exigida pelo 
mundo e pela sociedade, que traz para a escola e seus gestores, outros significados para o trabalho.

Compreendemos que se trata de outra formação, pois implica em uma proposta que articule aquisição de conhecimentos, procedimentos, saberes científicos e atitude política diante de seu trabalho, com o efetivo desenvolvimento de habilidades e competências que possibilitem: a compreensão dos aspectos teóricos educacionais, como as políticas públicas, a cultura escolar e da escola e os referenciais de gestão do trabalho; a articulação dialógica entre os diferentes segmentos do campo educacional; e a compreensão crítica entre a gestão escolar, as demandas e as percepções da sociedade civil.

Condição alheia a estas competências e habilidades, legitima que o ofício docente, assim como os que dele decorrem, seria apenas exercício laboral restringido-as à condição de semiprofissão, dado o desequilíbrio das forças, sobretudo externas, que controlam sua profissionalidade, deslegitimando o caráter educativo que deve ter a escola, sob o vil argumento do discurso democrático reducionista, a sugestão de conteúdos práticos voltados para a eficiência e à mercantilização das atividades profissionais (SACRISTÁN, 1998). Logo, a atividade dos gestores escolares não é exclusivamente técnica, o que implica na análise de seus processos de constituição.

Ao defendermos que formar gestores escolares competentes nas atividades de gestão escolar, no sentido de desenvolvimento intelectual dos diferentes sujeitos que constituem a escola, reconhecemos que se trata de uma tarefa permanente de exercício de liderança escolar, como possibilidade permanente de apoio aos docentes, que realizam a atividade nuclear da escola e portanto, lidam cotidianamente com a complexidade que enreda o trabalho escolar, exigindo iniciativas que favoreçam o trabalho colaborativo e o entendimento da missão social que a escola tem a cumprir.

Esta liderança precisa ser capaz de apoiar os professores durante as constantes mudanças para: investir no protagonismo participativo, fortalecer a sustentabilidade de práticas escolares exitosas e implantar o projeto da escola, 
buscando alternativas que superem os problemas próprios da estrutura institucional. Isto faz com que a profissionalidade dos gestores escolares seja uma tarefa nada fácil, nem tampouco alheia à abrangência do cotidiano educacional.

Ademais, quando nos referimos aos desafios da profissionalidade dos gestores escolares e educacionais, incluímos também a tarefa de constituíremse como formadores da profissionalização dos professores (PERRENOUD, 2003), à medida que o sentido do trabalho de gestão deve ser a garantia das condições adequadas ao exercício do ensino, e conquanto qualitativamente relevantes para situações de aprendizagem.

Embora este processo tenha início nos espaços acadêmicos, é na escola, circunstanciada pelas questões específicas e cotidianas, que os professores afirmam a pertinência dos seus saberes e vivenciam desafios que evocam as capacidades de construírem outras respostas para o trabalho.

No movimento de conscientização crítica acerca da profissão, os professores vão lapidando seu profissionalismo e este processo precisa ser mediado pela ação daqueles que atuam no suporte pedagógico da atividade docente e na organização do trabalho escolar, que, ao mesmo tempo, vão construindo outras formas de trabalho e de compreensão da gestão, e isto exige profunda mudança na profissionalidade e na profissionalização dos gestores escolares.

A mudança, a qual no referimos, pressupõe participação críticocolaborativa de diferentes segmentos, uma vez que requer que os gestores, no papel de profissionais intelectuais, implementem uma forma de coordenação pedagógica, que envolva todos os sujeitos no compromisso de aprender; administrem a escola com propósito de vincularem todas as dimensões do trabalho na escola; supervisionem a educação com a postura propositiva e investigadora, acerca de outras alternativas para a resolução dos dilemas da escola; e planejem o trabalho pedagógico com foco nas prioridades institucionais.

Esta expectativa de mudança do trabalho é algo que não pode prescindir de uma prática dialética e dialógica, superando metodologias estáticas ou 
fragmentárias de gestão da escola. Se isto não acontecer, correr-se-á o risco destes profissionais se tornarem meramente gerentes de afazeres escolares, subtraindo, de seu ofício, o caráter intelectual, político e pedagógico que devem ser permanentes.

\subsection{O que dizem os profissionais da gestão escolar a respeito dos desafios de sua profissionalidade}

Quando tratamos dos fazeres dos profissionais da educação, estamos também lidando com o que Fullan (2009) denomina como um dos elementos da mudança do processo educacional, e não apenas um conjunto de ações que se configura como mais uma reforma que abrange a proposta curricular, a estrutura de fluxos e as atribuições profissionais.

Defender a mudança na educação pressupõe também a formulação de outra maneira de organização no modo de agir dos docentes e, neste caso, principalmente dos gestores escolares, o que está relacionada ao modo de como Ihes são apresentados os conteúdos formativos em seu processo de formação inicial, no nosso caso, no curso de Pedagogia.

Agir profissionalmente em favor de mudanças que promovam a atuação profissional mais eficaz e qualitativa exige dos gestores escolares uma postura que articule o "ser crítico reflexivo" ao "ser intelectual"68, como uma tentativa de romper com a racionalidade técnica no trabalho dos profissionais do magistério, baseado numa lógica supostamente instrumentalista para a formação dos mesmos, numa referência ao modelo de "habilitações" que supunha conhecimentos segmentados entre si, seriam capazes e suficientes para tornar os sujeitos competentes para atuarem nos diversos segmentos da escola, ou ainda compreender a escola integralmente.

\footnotetext{
68 Nos referimos à distinção apresentada por Giroux (1997) e Zeichner (2002), ao apresentarem que a capacidade do profissional do pensar é algo que o torna reflexivo à medida que coloca em função da resolução mais qualitativa e eficaz dos problemas as capacidades resolutivas provindas do conhecimento e do pensamento que já tem. Entretanto a intelectualidade se mostra como uma forma mais abrangente, integradora e sistêmica de "pensar" em como lidar com estas questões, inclusive fazendo uso das condições e oportunidades culturais já construídas e possíveis na organização do pensamento para atuar.
} 
Alternativamente deve-se optar por uma concepção que agregue a complexidade da realidade, os dilemas do exercício da profissão e os saberes construídos pelos profissionais (saberes práticos com saberes políticos e científicos), o que conceituaríamos como práxis.

Práxis se constitui como uma forma de enfrentar o discurso de que a teoria pedagógica é algo menos valoroso durante o fazer profissional, ou inversamente, que o fazer dos profissionais está relegado a uma categoria de saber menos significativo para a constituição e compreensão do ofício dos gestores escolares e dos professores.

De acordo com os depoimentos dos profissionais do magistério responsáveis pela gestão escolar - professores coordenadores, diretores de escola e supervisores de ensino - um dos grandes desafios com o qual se deparam no exercício de seus ofícios é a superação da dicotomia entre a teoria e a prática.

A contradição a que nos referimos se refere ao que se espera como resultante do trabalho dos gestores escolares e aquilo que, de fato, conseguem realizar no seu cotidiano, permanentemente agindo na urgência que contribui para o isolamento de cada profissional, como se uma destas categorias de ofício devesse, ou pudesse existir, prescindindo uma da outra.

Embora já tenhamos apresentado no capítulo anterior, entendemos como gestão escolar o conjunto de práticas e concepções que orientam o modo e a forma de articulação dos diferentes segmentos do trabalho educativo na escola, de maneira que seja possível o desenvolvimento do projeto da instituição, considerando as políticas de sistema no qual a escola está inserida e as demandas decorrentes dos sujeitos que fazem parte deste contexto.

Tal compromisso com protagonismo crítico, se compromete com o propósito de garantir diferentes e significativas situações de aprendizagens de alunos e profissionais, e portanto, destacamos que o foco de todo seu trabalho escolar deve estar voltado para a melhoria do desenvolvimento pedagógico institucional. 
Nesta perspectiva de gestão escolar que apresentamos, insere-se a necessidade da prática dialógica, dialética e intelectual, condição que pressupõe um modo de agir dos gestores para além da adesão a rotinas procedimentais de organização do trabalho, e que também não é aferido apenas por indicadores sejam eles internos ou externos, mas sobretudo, pelos movimentos de trabalho que implicam na mudança da cultura da escola, em especial as que são públicas, como priorizamos nesta pesquisa.

Como tratamos no capítulo 1 , desde a implementação do curso de Pedagogia no Brasil, no final da década de 1930, a formação dos profissionais do magistério responsáveis pelas atividades de administração, planejamento, coordenação, inspeção, orientação e supervisão, padece de clareza e identidade mais definida.

Lidamos com esta relatividade do fazer quando tratamos das matrizes teóricas que orientam o que de fato distingue cada um destes profissionais, quando nos voltamos para a identificação do que é que os articula do ponto de vista da atuação profissional e o que, a nosso ver, é essencialmente o sentido de ser pedagogo na escola, isto é fundamental analisar os possíveis impactos da formação destes profissionais sobre sua profissionalidade no âmbito das escolas, principalmente.

Historicamente, a década de 1990 foi marcada pelo aumento sem precedentes do número de profissionais formados em Pedagogia, quer seja por meio da alternativa da complementação pedagógica dos cursos de licenciatura em Pedagogia com suas diversas (e dispersas) habilitações, e também dos cursos de especialização.

Entretanto, o fato desta multiplicação acelerada dos cursos e a indefinição de diretrizes curriculares alinhadas com as demandas escolares não contribuiriam para a presença de conhecimentos necessários para lidar com os desafios cotidianos, resultado dos movimentos de ampliação de uma formação aligeirada e compensatória, caracterizada principalmente, a partir do final da década de 1960, marcou não somente a formação dos docentes, mas sobretudo dos demais profissionais do magistério. 
Como efeito da multiplicação de habilitações consagrada pelo Parecer CFE 252/69, foi aprofundada a visão de que o fazer de cada um destes profissionais carecia de aprofundamento e especificidade tal que se desvincularia ou tornar-se-ia independente dos demais campos de atuação destes profissionais. Este é um reflexo dos resultados das reformas na Pedagogia sem garantir efetivamente uma mudança no que se esperava dos seus profissionais no sentido de transformar a escola e a educação.

Uma das conseqüências deste fato foi a disseminação, até meados da década de 1980, de um modo de fazer profissional que tornasse o ofício da administração uma forma quase programática de controle dos fluxos internos da escola; a atividade de supervisão como um instrumento ora de inspeção das demandas do Estado, ora de um segmento de alinhamento legal; a orientação como uma possibilidade de auto identidade dos sujeitos com a escola; a coordenação pedagógica como um mecanismo de divulgação das propostas curriculares de tempos em tempos editadas, como se todas estas atividades não estivessem vinculadas pela sua finalidade e seu sentido de existência ${ }^{69}$.

Mais recentemente, a literatura especializada tem se dedicado não apenas à conceituação do que é gestão, mas também à discussão a respeito do papel e do sentido da gestão escolar no sistema educacional, em razão de inúmeras iniciativas governamentais, que focam, ao menos em tese: a melhoria dos resultados educacionais, a ampliação do envolvimento dos diferentes segmentos na construção e discussão da cultura escolar, a mudança do padrão de organização e a construção de matrizes curriculares de referência no sistema; além dessas, otimização e desburocratização da transferência de recursos e responsabilidades.

69 A pesquisa de doutoramento realizada por Pinto (2006) apresenta algumas das características da forma de atuação do pedagogo escolar no campo da coordenação, orientação e direção, a partir da análise do movimento histórico das mudanças da escola e as implicações sobre estes profissionais, considerando o processo de construção da identidade destes sujeitos e ofícios. No caso da supervisão de ensino, Tachinardi (2007), em sua tese de doutoramento, contemplou a historicidade da supervisão de ensino mais detalhadamente no estado de São Paulo, e assim os conflitos e dilemas na construção da identidade profissional que a pesquisadora defende. 
É de se presumir que a formação destes profissionais, precisa, de alguma forma, tecer interseções com esta perspectiva de atuação baseada na autonomia, na intelectualidade e na complexidade, inclusive para que possa se avançar naquilo que atualmente se espera daqueles que realizam a gestão escolar, tanto para a melhoria dos resultados e conseqüências do trabalho que vem sendo realizado nas escolas, como para a construção de argumentos profissionais que sejam suficientemente capazes de confrontarem propostas que eventualmente desprezem o caráter emancipatório que deve estar presente no trabalho a ser realizado pelos gestores escolares.

Analisando as questões de número 1 e 3 dos questionários aplicados a professores coordenadores pedagógicos (16), diretores de escola (14) e supervisores de ensino (12), percebemos que a atuação dos gestores escolares é identificada mais permanentemente por atividades que poderiam ser contempladas em três grandes dimensões: filosófica doutrinária (ligada à missão educativa), formativa organizacional (ligada às atividades essenciais no trabalho educativo) e prática operativa (ligada às rotinas cotidianas necessárias), como procuramos sistematizar no quadro a seguir:

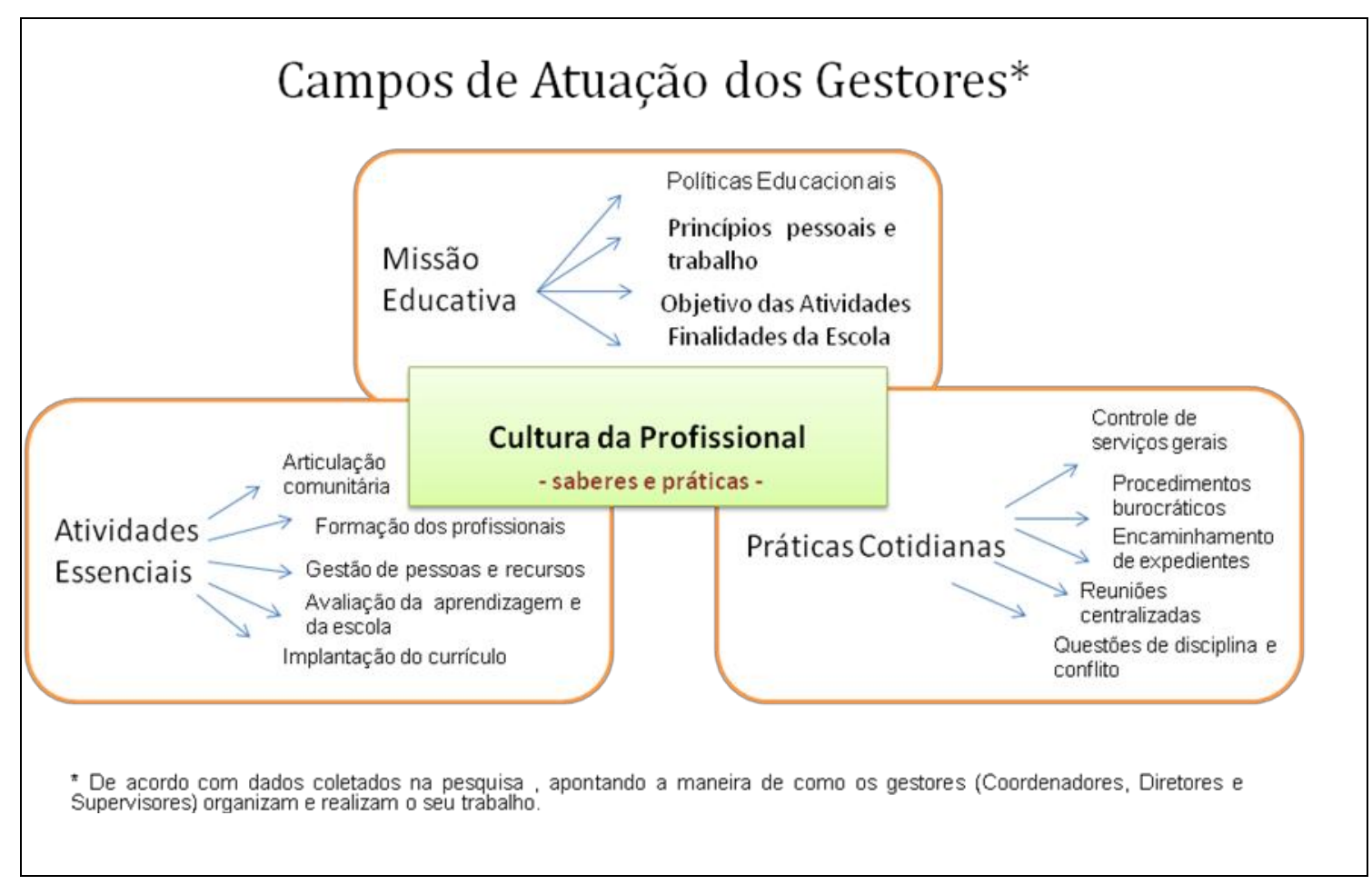


O quadro apresentado sistematiza os principais elementos que estão presentes no trabalho dos gestores escolares, classificados em três campos de atividades, atividades estas que foram apresentadas pelos gestores participantes da pesquisa.

É certo apontar que algumas delas, como encaminhamentos de expedientes e reuniões centralizadas, são mais intensas aos diretores e supervisores, enquanto que a formação dos profissionais tem maior presença nas respostas dos professores coordenadores, portanto, o esquema se refere à apresentação das atividades comuns, variando sua intensidade.

A existência de atividades compartilhadas pelos gestores na realização das atividades de gestão da escola demonstra que embora exista especificidade no ofício de cada profissional, há um conjunto de saberes teóricos, práticos e técnicos aos quais não podem prescindir para uma atuação mais eficaz e portanto, precisam se fazer presentes na sua formação. Contudo, as atividades dos campos mais práticos estão diretamente vinculadas à missão educativa da escola púbica, ou seja, à concepção política que aderem ao trabalho.

O conjunto de atividades que são apontadas pelos profissionais demonstra a complexidade exigida para a realização do trabalho dos gestores, e que para tanto não se restringe à aquisição de conhecimentos isolados nem tampouco estratégias lineares para resolução dos problemas e dos desafios escolares.

Avigora-se a importância de que a atuação dos gestores ocorra a partir de práticas colaborativas de compreensão da cultura da escola e atuação sobre ela, o que, a nosso ver, implica na construção de uma cultura profissional própria para cada instituição, em que pese os referencias de identidade de cada ofício e para referenciais de identidade para as escolas. Então, como estes saberes e estas práticas estão presentes na formação inicial dos gestores escolares? 
O que notamos, pela constatação destes diversos aspectos que aparecem ao tratarmos do que fazem os gestores, é que a concepção de gestão presente nesta idéia de articulação de diferentes dimensões do trabalho dos profissionais do magistério se assenta num movimento de articulação dos vários aspectos de funcionamento e motivos de existência da escola pública no Brasil.

Neste caso, a atuação destes profissionais gestores não pode se materializar por meio de procedimentos cartesianos, que até eventualmente poderiam solucionar determinados problemas e entraves da escola, mas poucos seriam eficazes para enfrentar os dilemas da escola e do sistema educativo, marcados pela complexidade.

O que já sinalizamos, é que do mesmo modo que a atuação dos gestores escolares é uma atividade altamente complexa e multifacetada, sua formação inicial nos cursos de Pedagogia vem sendo garantida apenas pela apresentação de conteúdos apresentados genericamente, seja do ponto de vista de disciplinas curriculares, atividades complementares, ou seja, do ponto de vista de problemas isolados.

Ao invés da possibilidade de atuar a partir de práticas da colaboratividade, a profissionalidade dos gestores escolares, seja por sua formação, pela estrutura dos sistemas ou mesmo pelas condições de trabalho postas, acaba se caracterizando muitas vezes pelo isolamento, uma vez que o trabalho realizado pelos gestores escolares, embora pensado a partir de outros referenciais teóricos, se depara com elementos culturais e determinantes políticos que favorecem o exercício fracionado de seu ofício.

Os depoimentos trazidos pelos gestores escolares (professores coordenadores pedagógicos, diretores de escola e supervisores de ensino) demonstram o conhecimento de uma matriz de atuação apresentada pela Secretaria de Estado da Educação de São Paulo - SEE SP, que destaca o fundamento pedagógico de seu trabalho. Entretanto, alguns aspectos culturais 
e organizacionais que circunscrevem suas práticas obstaculizam esta realização.

Procuramos analisar, a partir das categorias apresentadas por Lima (2002), os principais desafios que os gestores escolares apresentam para atuar efetivamente numa proposta de colaboratividade, analisando a natureza das habilidades e capacidades requeridas para se enfrentar os diversos problemas de trabalho, conforme o que fazem no dia a dia, e as principais dimensões culturais do trabalho dos educadores.

Ressalte-se que as condições de trabalho sob as quais atuam e de como o realizam, de acordo com o que apresentaram nos questionários aplicados, indicam que a formação dos gestores escolares precisa apontar possibilidades de que identifiquem e atuem sobre: a amplitude da interação das atividades de trabalho (dimensão dos sujeitos que conseguem envolver no trabalho educativo); a freqüência desta interação (o modo pelo qual é sistematizado o trabalho e sua permanência); e a abrangência da interação (de que modo o trabalho dos gestores implica sobre o dos demais profissionais e a escola).

Estes aspectos acerca da forma de atuação nos levam a considerar que para atuarem nesta perspectiva é significativo que sua formação inicial, como já tratamos, se dedique efetivamente à compreensão da escola de forma sistêmica e integrada, à profissionalização, que se opõe à idéia das extintas habilitações da Pedagogia.

Para tanto, identificamos as principais capacidades exigidas aos gestores escolares, em relação às dimensões do trabalho, segundo a percepção dos próprios sujeitos que participaram da pesquisa: 
CAPACIDADES EXIGIDAS NAS DIMENSÕES DO TRABALHO DO GESTOR

\begin{tabular}{|c|c|c|c|}
\hline $\begin{array}{l}\text { Dimensões da } \\
\text { Cultura de } \\
\text { Trabalho }\end{array}$ & $\begin{array}{l}\text { Principais } \\
\text { Capacidades/Habilidades } \\
\text { exigidas, segundo os } \\
\text { Professores } \\
\text { Coordenadores }\end{array}$ & $\begin{array}{l}\text { Principais } \\
\text { Capacidades/Habilidades } \\
\text { exigidas, segundo os } \\
\text { Diretores }\end{array}$ & $\begin{array}{l}\text { Principais } \\
\text { Capacidades/Habilidades } \\
\text { exigidas, segundo os } \\
\text { Supervisores }\end{array}$ \\
\hline Densidade & $\begin{array}{l}\text { - reconhecer a equipe } \\
\text { docente como foco de } \\
\text { organização de seu } \\
\text { trabalho; } \\
\text { - identificar as } \\
\text { características dos alunos } \\
\text { da escola, sugerindo } \\
\text { alternativas para o } \\
\text { trabalho pedagógico; } \\
\text { - articular } \\
\text { pedagogicamente as } \\
\text { ações de formação dos } \\
\text { professores; } \\
\text { - participar intensamente } \\
\text { na implantação do projeto } \\
\text { pedagógico da escola }\end{array}$ & $\begin{array}{l}\text { - perceber o movimento do } \\
\text { trabalho escolar e os } \\
\text { fatores que implicam sobre } \\
\text { como todos atuam; } \\
\text { - mediar } \\
\text { permanentemente as } \\
\text { relações interpessoais } \\
\text { entre os sujeitos que } \\
\text { participam da escola; } \\
\text { - conhecer o projeto da } \\
\text { escola, } \\
\text { - mobilizar esforços } \\
\text { coletivos para a sua } \\
\text { implementação e } \\
\text { desenvolvimento. }\end{array}$ & $\begin{array}{l}\text { - compreender o sentido e } \\
\text { as implicações das políticas } \\
\text { públicas estaduais e a sua } \\
\text { forma de interferência sobre } \\
\text { o projeto pedagógico da } \\
\text { escola, podendo contribuir } \\
\text { para sua articulação; } \\
\text { - compreender a } \\
\text { característica profissional } \\
\text { de cada uma das equipes } \\
\text { escolares, e suas } \\
\text { influências sobre a cultura } \\
\text { de cada instituição; } \\
\text { - distinguir a cultura } \\
\text { institucional de cada uma } \\
\text { de suas escolas, e as } \\
\text { práticas decorrentes desta } \\
\text { condição. }\end{array}$ \\
\hline Centralização & $\begin{array}{l}\text { - articular os professores } \\
\text { em torno dos objetivos de } \\
\text { formação dos horários } \\
\text { específicos; } \\
\text { - organizar os professores } \\
\text { para que tenham práticas } \\
\text { colaborativas de trabalho; } \\
\text { - coletar informações } \\
\text { referentes à organização } \\
\text { pedagógica da escola, } \\
\text { para socialização com os } \\
\text { professores; } \\
\text { - acolher do diretor de } \\
\text { escola as demandas para } \\
\text { o trabalho de } \\
\text { coordenação. }\end{array}$ & $\begin{array}{l}\text { - responder, se possível, } \\
\text { imediatamente sobre } \\
\text { problemas escolares de } \\
\text { todas as complexidades; } \\
\text { - atuar, mesmo com a } \\
\text { carência de equipe, de } \\
\text { maneira que possa } \\
\text { partilhar a realização mais } \\
\text { racionalizada das } \\
\text { atividades escolares; }\end{array}$ & $\begin{array}{l}\text { - concentrar as informações } \\
\text { sobre as mudanças e } \\
\text { diretrizes legais para } \\
\text { orientação aos demais } \\
\text { gestores; } \\
\text { - organizar } \\
\text { permanentemente a equipe } \\
\text { de supervisão de ensino da } \\
\text { diretoria como espaço de } \\
\text { decisões e deliberações; } \\
\text { - sistematizar as } \\
\text { informações dos setores e } \\
\text { atribuições de trabalho, } \\
\text { para a reorientação da } \\
\text { atividade profissional; } \\
\text { - identificar as diferenças e } \\
\text { semelhanças do trabalho } \\
\text { pedagógico das escolas, } \\
\text { promovendo práticas } \\
\text { colaborativas de }\end{array}$ \\
\hline
\end{tabular}




\begin{tabular}{|c|c|c|c|}
\hline & & & intercâmbio. \\
\hline Fragmentação & $\begin{array}{l}\text { - responder a inúmeros } \\
\text { expedientes e informações } \\
\text { solicitadas repetidamente } \\
\text { pelos órgãos centrais, } \\
\text { - realizar atividades } \\
\text { escolares que não são } \\
\text { próprias da coordenação } \\
\text { pedagógica, mas se } \\
\text { apresentam pela falta de } \\
\text { equipe de trabalho } \\
\text { operacional }\end{array}$ & $\begin{array}{l}\text { - emitir documentos } \\
\text { excessivamente } \\
\text { informativos, } \\
\text { principalmente para as } \\
\text { Diretorias; } \\
\text { - realizar atividades } \\
\text { enfaticamente de caráter } \\
\text { administrativo e financeiro, } \\
\text { exigindo a dedicação } \\
\text { intensa de tempo para } \\
\text { procedimentos que não } \\
\text { permitem atuar } \\
\text { intensamente nas ações } \\
\text { pedagógicas. }\end{array}$ & $\begin{array}{l}\text { - responder a inúmeros } \\
\text { expedientes administrativos } \\
\text { que não demonstram a } \\
\text { aprendizagem como } \\
\text { prioridade; } \\
\text { - verificar as condições de } \\
\text { funcionamento permanente } \\
\text { e precário de muitas } \\
\text { escolas, preterindo o } \\
\text { acompanhamento } \\
\text { formativo. }\end{array}$ \\
\hline
\end{tabular}

Nota-se que as capacidades exigidas aos gestores escolares em seus diferentes ofícios remetem à compreensão da escola como uma unidade hipercomplexa de trabalho e portanto, que não se restringe aos conhecimentos específicos de determinados campos de atuação (administrativo, pedagógico, legal e humano). Este fato exige que estes profissionais detenham conhecimentos capazes de ampará-los no olhar e atuar sobre a cultura institucional.

Entretanto, quando analisamos as 130 matrizes dos cursos de Pedagogia que se dedicam também à formação dos gestores escolares e educacionais, notamos algumas situações formativas que assim caracterizamos e agrupamos em quatro campos:

$\left.1^{\circ}\right) 42 \%$ dos cursos de Pedagogia analisados tratam a formação do gestor escolar como uma área praticamente complementar à docência, restringindo-se ao oferecimento da disciplina Gestão Escolar ou Gestão Educacional e eventuais inserções nos instrumentos de gestão (legislação, currículo, avaliação, ainda que estes tenham enfoque para a formação docente).

Esses cursos, não raramente, oferecem várias disciplinas de 40 horas, 2 ou 3 semestres do curso, implicando numa proposta de formação generalista, que apresenta os princípios conceituais do que a literatura tem chamado de 
gestão escolar, desconsiderando a complexidade do próprio tema, ou ainda, a abrangência pela qual deve ser tomada esta atividade de atuação.

Neste caso, corre-se o risco de que a formação dos gestores escolares seja marcada pela ausência de conhecimentos relacionados aos legítimos campos de atuação destes profissionais quando do exercício de seu trabalho, ou mesmo realizando equivocadamente uma transferência de conhecimentos da docência para a gestão, como se esta não fosse dotada de identidade própria;

$\mathbf{2}^{\circ}$ ) Os dados coletados pelas matrizes curriculares, demonstram ainda que $28 \%$ das instituições restringem a formação mais especificamente para as atividades de suporte pedagógico, incluindo em seus currículos disciplinas como "Gestão Escolar" ou "Gestão Educacional".

Além disso, $84 \%$ dos cursos com essa estruturação são de natureza privada, predominantemente em faculdades isoladas, que por terem como missão basicamente a oferta do ensino, não desenvolvem experiências de formação dos gestores, nem tampouco dos docentes, e muito menos se orientam por procedimentos de pesquisas e práticas investigativas para a resolução de problemas de gestão nas instituições escolares;

$3^{\circ}$ ) $74 \%$ dos cursos de Pedagogia analisados dedicam algumas disciplinas à formação de gestores escolares, porém, elas estão vinculadas aos aspectos gerais do trabalho da escola ou do sistema educativo, encontrando maior incidência de disciplinas relacionadas à avaliação, currículo, legislação; ao invés dos problemas, desafios e os contextos escolares.

Apesar de haver neste grupo a virtude de uma maior diversificação de disciplinas que possam contemplar conteúdos mais abrangentes sobre a organização da escola, o que pode contribuir para maior possibilidade de se estabelecer intersecções entre o que fazem os profissionais e os dilemas escolares, ainda predomina uma organização segmentada, proposta em blocos de conteúdos da atividade profissional, permanecendo a proposta diluída de formação dos gestores escolares ao longo do tempo formativo, como se os 
conteúdos de trabalho se configurassem isolados e não se constituíssem na articulação entre si na escola e no sistema escolar;

$4^{\circ}$ ) $14 \%$ dos cursos de Pedagogia apresentam proposta de organização curricular com disciplinas dedicadas ao estudo de questões conceituais e balizares da gestão escolar e educacional, mas que também integram estes conceitos aos problemas e desafios que fazem parte do trabalho dos gestores escolares como: a compreensão da escola como um organismo institucional, dos campos de atuação do gestor escolar como instrumento de articulação com o trabalho docente, de compreensão da inserção das instituições educativas no contexto de sistemas de ensino.

No capítulo 3, iremos aprofundar a configuração das propostas dos 130 cursos de Pedagogia que formam gestores escolares no Brasil, trazendo os dados qualitativos e quantitativos sobre a organização do currículo, as oportunidades formativas, a articulação de estágios e atividades complementares, além da apresentação de possibilidades optativas de aprofundamento da formação dos pedagogos que atuarão como gestores escolares, levando em consideração o que os atuais gestores apontam como necessidades e demandas no que fazem.

Um dos lados perversos deste modo de formação que não dedica o devido destaque à profissionalização dos gestores escolares é o de permanecer com uma proposta segmentada do ponto de vista dos campos de atuação, fracionada no aspecto de cada atividade, e superficial quanto o significado do que precisam fazer estes profissionais na escola para construir culturas mais colaborativas.

Esta forma de fracionamento do trabalho dos gestores permite que se continue transferindo a responsabilidade sobre a própria formação, atuação e conquista de resultados a cada profissional; que se mantenha o controle e a subordinação impostos pelos planos governamentais, marcantemente definidos pelo imperativo da execução do trabalho, da intensificação da atuação e da expropriação dos conhecimentos produzidos no interior da profissão e pelos 
sujeitos. Isto provoca que o que se denomina o "mal estar docente" estendido não apenas aos docentes, mas também aos gestores escolares.

Para Sacristán (1998), a condição do ofício docente e, neste caso, ampliamos a leitura para o caso dos gestores escolares, que o são em condições diferenciadas de exercício, se consolida à medida que detém maior reconhecimento social a respeito da importância de tal tarefa, capacidade de construção de status, regulação de seu ofício e propriedade dos elementos que orientam a forma de exercício da atividade profissional.

A melhoria das oportunidades e das alternativas de formação dos gestores escolares precisa estar de algum modo relacionada a como se define seu modo de trabalho e se estabelece as prioridades de trabalho, o que representa uma manifestação de autonomia profissional.

A rede estadual de educação de São Paulo estabeleceu uma matriz de competências para a realização do trabalho dos gestores escolares em sua atividade profissional, com o objetivo de fortalecer e otimizar os esforços e intensificar a presença do fazer pedagógico nas práticas de gestão desenvolvidas.

Como tratamos anteriormente no quadro do tema 2.2, a matriz de competências defendida pela Secretaria de Estado da Educação de São Paulo é amplamente contemplada pelo perfil do egresso dos cursos de Pedagogia, estabelecido pelas Diretrizes Curriculares do Curso, nos termos da Resolução CNE CP 01/06, o que não significa necessariamente que tal perfil tenha sido contemplado no interior dos cursos de formação, como será discutido no capítulo 3. Essa constatação nos leva a compreender que há um movimento descompassado entre a formação proclamada e a formação praticada.

Também como parâmetro de análise a respeito de como os gestores escolares realizam seu trabalho nas escolas e no sistema, e quais competências são mais mobilizadas para realizar estas atividades, traremos alguns dados que apontam como as capacidades e habilidades exigidas no cotidiano se relacionam ao que lhes é (e se é) pretensamente apresentado nos cursos de formação em Pedagogia. 
Nosso intuito é o de comparar o que é previsto regimentalmente pela Secretaria e a intensidade de mobilização destas competências no seu dia a dia, de modo que possamos validar ou refutar a importância destas competências constarem nas matrizes de formação dos cursos.

No questionário aplicado, estabelecemos uma escala de indicação de prioridades destas competências mobilizadas na realização do trabalho, que variou de 1 (um) para as competências menos presentes e mobilizadas e 5 (cinco) para as competências mais mobilizadas. As competências foram agrupadas pelos focos de trabalho que identificamos nos documentos legais da rede estadual que tratam do perfil dos profissionais envolvidos nesta pesquisa $^{70}$.

As respostas formuladas pelos gestores escolares, que foram coincidentes com a literatura contemporânea sobre a gestão escolar e educacional e com os referenciais que orientam as matrizes de competências estabelecidas pelo sistema estadual, reconhecem o que é elencado como prioridade, efetivamente se colocando como o grande propósito de trabalho cotidiano, demonstrando que há relativa convergência entre o perfil de gestor escolar apresentado pela SEE SP, e os aspectos do trabalho para os quais os gestores estabelecem foco na profissionalidade:

Análise dos eixos de atuação x competências mobilizadas pelos gestores

\begin{tabular}{|l|c|c|c|}
\hline Focos de trabalho dos gestores & $\begin{array}{c}\text { Professor } \\
\text { Coordenador }\end{array}$ & $\begin{array}{c}\text { Diretor de } \\
\text { Escola }\end{array}$ & $\begin{array}{c}\text { Supervisor de } \\
\text { Ensino }\end{array}$ \\
\hline Aprendizagem & 4,2 & 4,4 & 4,1 \\
\hline Ensino e Planejamento & 4,4 & 3,9 & 4,7 \\
\hline Avaliação & 4,2 & 4,6 & 4,8 \\
\hline Currículos e Programas & 4,1 & 4,6 & \\
\hline
\end{tabular}

\footnotetext{
${ }^{70}$ No caso do Professor Coordenador Pedagógico, as matrizes de referência do perfil está na Resolução SE 88/07, enquanto que no caso de Diretores de Escola e Supervisores de Ensino, esta matriz de competências do perfil encontra-se publicada na Resolução SE 70/10, posteriormente atualizada pela Resolução SE 52/13.
} 


\begin{tabular}{|l|c|c|c|}
\hline Formação profissional & 4,6 & 3,6 & 4,0 \\
\hline Política Educacional e Sistema & - & 4,1 & 4,6 \\
\hline
\end{tabular}

As habilidades e competências previstas para os gestores nos dispositivos legais citados foram agrupadas nestes "focos do trabalho", e no questionário cada participante indicou a intensidade que prioriza este foco no seu exercício profissional. O conjunto de índices (de 1 a 5 ) atribuídos por cada segmento de gestores originou este índice médio de prioridade, por foco de trabalho e por oficio gestor.

Notamos que dentre as atividades que constituem os eixos orientadores do trabalho dos gestores, e que, portanto circunscrevem a sua profissionalidade de modo mais intenso são: a gestão da aprendizagem, política educacional e sistema educacional, e gestão dos processos avaliativos institucionais e de aprendizagem.

Identificados os eixos principais de atuação no trabalho dos gestores, é presumível que são os que mais exigem mobilização de competências, entretanto, carecem de ênfase na sua formação inicial, tanto do ponto de vista da constituição de um repertório teórico que possibilite a compreensão destes aspectos, como de experiências e reflexão sobre situações práticas que promovam uma relativa imersão na realidade de trabalho, e realizem uma leitura crítica dos contextos.

Mais uma vez, pode-se sugerir que a escola pública, no que se refere ao modo de funcionamento e de organização, precisa ser considerada em seu aspecto mais orgânico, uma vez que os resultados nos processos avaliativos da eficácia institucional são decorrentes da forma de gestão das situações de aprendizagem e de que modo se mobiliza para o desenvolvimento do currículo, e da própria formação de seus profissionais, ou seja, uma demonstração de qual é o perfil, o propósito e o modo de se fazer gestão em cada unidade.

Do mesmo modo, a compreensão a respeito das políticas educacionais e da forma pela qual a escola lida com as manifestações do sistema educacional em seu projeto definem a melhoria das situações de aprendizagem que a escola poderá oportunizar para seus alunos, ou de formação profissional para os que nela trabalham e, portanto, refere-se a como se realiza a gestão da formação e da aprendizagem na instituição e neste caso, como os gestores escolares constroem e desenvolvem sua profissionalidade. 
Se tomarmos por base o conceito de profissionalidade como a propriedade dos saberes e competências inerentes ao campo de trabalho, o controle de mecanismos de regulação sobre a produção destes saberes, e construção de saberes práticos que se consolidam pela exercício das formas de realização de seu ofício (não exclusivamente formas práticas de fazer, mas também o pensamento estratégico sobre o como fazer), concluiremos que o contexto de intensa regulação externa sobre os profissionais da educação demonstra, de fato, que os educadores não se constituem efetivamente como profissionais.

Reconhecer que o trabalho de gestão não é uma forma de aplicação de técnicas de organização institucional, mas sim uma atividade profissional que exige a interação dos saberes que se tem sobre o contexto com os princípios e finalidade que se deseja alcançar na instituição construindo assim uma forma específica de prática de gestão em cada instituição, ainda que existam referenciais orientadores gerais.

Pela ótica do protagonismo crítico, este trabalho de coordenação representa a significação do trabalho do gestor como tema de desenvolvimento pedagógico da escola, até porque a própria prática tematizada passa a objeto de investigação da profissionalização, que raramente avança para além da leitura superficial do "fazer prático", como brevemente indicamos quando apresentamos como as propostas de formação em Pedagogia tem tratado a gestão, na forma já superada de habilitações, seja na forma de licenciatura que permaneça compartimentando os referidos saberes.

A intensa contradição entre o que dizem fazer e o que julgam mais significativo reside não apenas em lacunas na compreensão sobre o seu ofício, mas também nas relações e condições materiais e efetivas de trabalho, e que remonta a como os gestores escolares, que supostamente são os profissionais que lidariam com o poder de articulação e mobilização para o avanço do projeto pedagógico, tornam-se alijados das reais condições de exercício do poder $^{71}$ inerente aos ofícios de gestores escolares, tornando-o apenas uma

${ }^{71}$ A forma de lidarmos com a gestão da instituição escolar, ou com o processo de administração da escola pública, tem a ver diretamente com a visão que temos sobre o suposto 
categoria sociológica pseudo praticada, e que se torna um obstáculo para a construção de uma cultura colaborativa de gestão dos processos educativos e escolares.

A relação entre uma relativa fragilidade na formação dos gestores escolares e sua inserção num campo de trabalho, no qual as condições reais de realização do mesmo não se apresentam suficientemente estruturadas, conforme vamos reconhecendo pelos dados desta pesquisa, remete a condição de exercício de um poder potencial, tanto da escola como de seus profissionais, uma vez que aquilo que se atribui à escola como possibilidade de fazer ou de decidir sobre o seu fazer padece de relação com aquilo que realmente se consegue realizar no cotidiano da escola.

De certo modo, esta dinâmica não raramente frenética do trabalho, exige muitas capacidades e habilidades dos gestores escolares, chegando ao ponto de impregná-los de dúvidas sobre o sentido dos seus fazeres, ampliando a indefinição do que realmente se é quando se atua em ofícios voltados ao suporte pedagógico, como apontam os participantes da pesquisa, em relação ao que lhes é exigido.

A ausência de compreensão sobre o sentido da gestão escolar induz muitos dos sujeitos que participam da escola a considerarem que atuar nestes ofícios pressupõe o afastamento da sala de aula, da docência e, principalmente, do que acontece na sala de aula, condição esta que provoca a desvalorização da atividade dos professores e a invalidação do que fazem os gestores escolares, dificultando ainda mais que atuem colaborativamente, como defendem Fullan e Hargreaves (2001), ao afirmarem que

Tradicionalmente, o ensino tem sido considerado uma carreira "plana". A única forma de alargar o nosso papel era afastarmo-nos da sala de aula para ocupar uma posição administrativa. Esta tradição encerra dois problemas fundamentais. Primeiro, passarem-se muitos anos no espaço da aula sem

poder existente na escola, e a concepção de educação que queremos organizar. Segundo Paro (2008), "o poder-fazer da escola que temos, já em termos potenciais, é muito menor do que o que ela oficialmente declara ter. As causas desse fracasso são muito variadas e, em sua maioria, tem sido denunciadas as mais diversas formas quer pela academia, quer pelos grupos interessados em solução. Mas uma importante causa pouco discutida e que parece estar na base de todo o problema do baixo desempenho do ensino é precisamente essa timidez de sua ambição no provimento de cultura". 
estímulo exterior substancial reduz o empenhamento, a motivação e a eficácia. As boas idéias e as inovações desenvolvidas pelos docentes, individualmente, estão muitas vezes inacessíveis aos outros membros da profissão. Passar anos a fio a desempenhar o mesmo papel é intrinsecamente enfraquecedor e provoca a dessensibilização. Vinte anos de experiência a fazer a mesma coisa equivalem a um ano de experiência multiplicado por 20 vezes.

As orientações curriculares obrigatórias também afectam as relações que os docentes mantêm com os seus colegas. O objectivo de conseguir que os professores trabalhem em conjunto de uma forma mais próxima pode ser prejudicado por um currículo que é visto por eles como estando de tal forma definido que existe pouca coisa acerca da qual possam colaborar. Portanto, um currículo, administrativamente controlado, pode estabelecer limites importantes na colaboração entre docentes. Nesse sentido, atribuir aos educadores e as escolas maiores responsabilidades no desenvolvimento do currículo pode constituir um dos maiores desafios a mudança do contexto do ensino. A separação entre currículo e ensino é um legado histórico que se pode transformar numa falácia educativa. É tempo de voltar a juntá-los. (FULLAN; HARGREAVES, 2001, p.31)

Os depoimentos trazidos pelos gestores escolares ainda indicam que há uma relativa ausência ou dualidade nos aspectos que constituem a identidade destes "formadores de professores", seja porque em muitos casos a condição para se tornar gestor parece ser a de necessariamente afastar-se da sala de aula, seja pelo fato de entenderem, em muitos casos, que a docência é um ofício do pedagogo na escola, sob o qual está prevista a tarefa de ensinar, enquanto a outros pedagogos "mais especializados", compete compreenderem mais amplamente a escola, e estes seriam os verdadeiros gestores.

Isto significa que desde a formação inicial destes profissionais, e posteriormente durante sua atuação, é fundamental a construção de saberes que contribuam para que os mesmos sejam capazes de fazer de seu ofício uma profissão, aprimorando a compreensão e a capacidade de análise das práticas que constituem sua profissionalidade.

Os gestores escolares, que participaram desta pesquisa, indicam que os conhecimentos trazidos no curso de Pedagogia, quando de sua formação superior inicial, são insuficientes e relativamente descolados do que fazem e de como atuam em suas escolas. Isto demonstra a fissura que permanece entre três aspectos da formação profissional dos profissionais do magistério: o que se propõe a formar, o que se forma e o que se faz durante o exercício do trabalho. Por outro lado, demonstra por parte dos gestores um grau mais significativo da compreensão a respeito dos papeis profissionais exigidos e da 
insuficiência de conhecimentos de diversas naturezas para se enfrentar tais desafios.

Como efeito destas condições insuficientes para o exercício do ofício de gestores escolares, multiplicam-se as propostas que supostamente seriam capazes de melhorar a formação profissional, intensificando-se a responsabilização destes profissionais acerca dos resultados da escola, justificando-se a inexistência de investimentos permanentes e reais na carreira sob a lógica da meritocracia, aprofundando-se o mal estar sobre os profissionais do magistério, inclusive afirmando-se que, em muitas vezes, os resultados institucionais são absolutamente decorrentes das ações dos gestores escolares e dos seus professores.

Tal fato circunscreve-se num campo de intensificação das relações de controle e de redução da autonomia de trabalho dos profissionais do magistério, conferindo-lhes capacidades e atribuições excessivamente baseadas no "dever de", e num escopo de práticas externamente definidas por agentes que são responsáveis pela indicação de políticas públicas mais amplas, objetivos do sistema educacional, metas educacionais de Estado, preterindo-se o valor do projeto da escola, e como devem os gestores atuar sobre ele, o que os torna não raramente meros executores de planos e de tarefas, alijados do processo de decisão, como denuncia Contreras (2002).

Para Fullan \& Hargreaves (2001), os sistemas educativos são modalidades organizativas nas quais os sujeitos expressam suas crenças, demonstram suas contradições e constroem seus saberes, inclusive a partir dos dilemas da profissão. Isto significa que constroem a cultura profissional de seu ofício e os supostos dispositivos (psicológicos, práticos e intelectuais) utilizados para o enfrentamento do que imaginam como ameaças reveladas nas suas formas de organização social para a profissionalidade.

Partindo da idéia anterior, podemos conceber que a construção da profissionalidade é um fenômeno também histórico e não apenas técnico e portanto, compreender a atividade profissional dos gestores escolares é uma das formas de indagação acerca do que se estabelece como matriz do profissional competente, que envolve práticas complexas de atuação e muitas 
vezes contraditórias, pois anunciam uma suposta autonomia, mas também reproduzem e denunciam o controle burocrático do seu trabalho e o trabalho docente.

No âmbito do desenvolvimento das escolas, a heresia do individualismo é um dos grandes dilemas a serem compreendidos e não apenas refutados, como se a colaboração e colegialidade fossem as únicas formas possíveis de articulação e de realização do trabalho profissional, algo que é intensamente proposto pelas reformas educativas, e assim apresentado como um dos imensos desafios aos gestores escolares, senão o maior deles.

Diferente disso é a capacidade do gestor reconhecer que diferentes atividades a serem desenvolvidas na escola requerem possivelmente formas plurais de organização das equipes, o que não afasta a importância da partilha dos interesses e necessidades comuns.

As prioridades que os gestores estabelecem para a organização de seu trabalho, conforme vimos no primeiro quadro desta subseção, demonstram que a mudança por eles desejada e a perseguição de resultados mais satisfatórios para suas escolas não se conquista apenas por práticas individualizadas ou baseadas em atividades estritamente técnicas.

Logo, isto requer dos gestores competências para articular os princípios e objetivos do projeto da escola, as expectativas e capacidades do trabalho dos indivíduos, além das orientações que integram o sistema educacional, como afirmam Fullan e Hargreaves (2001):

Os profissionais de uma escola precisam também ter consciência de que nem sempre a necessidade real do grupo coincide com as necessidades da própria instituição. As vezes os professores constatam os problemas, mas não se sentem motivados a enfrentá-los com a energia necessária. Em certos casos, alguns problemas precisam ser solucionados antes de outros. Por exemplo, a equipe tem consciência de que há muitos problemas de disciplina a resolver, mas a necessidade real do grupo é de ter mais apoio da direção e das autoridades do ensino. Perante essas situações, os dirigentes escolares precisam ter lucidez e competência parar formular as melhores estratégias de tomadas de decisão, fazendo combinar as necessidades sociais e mais amplas a atender $e$ as necessidades do grupo de professores (FULLAN; HARGREAVES, 2001, p.89).

Paradoxalmente, o discurso do trabalho coletivo há tempos incorporado pelo repertório existente na literatura educacional e dos profissionais da 
educação em muitos espaços escolares, acaba configurando um cenário de senso comum, constituindo, muitas vezes, contextos de isolamento de trabalho e gerando um avanço ilusório na gestão, na qual resultados são aparentemente exitosos.

Porém, diante disso, não se muda a cultura da escola, ora por práticas clandestinas que também não contribuem para a apropriação de aprendizagens mais significativas, ou ainda, colegialidades falsamente constituídas, pautando-se fundamentalmente na lógica burocrática, agregando raras contribuições para uma gestão que priorize a criatividade profissional, a autonomia dos profissionais e o desenvolvimento institucional.

$\mathrm{Na}$ pesquisa realizada, os gestores escolares afirmam que o curso de Pedagogia é marcado por uma série de rupturas entre o que se propõe como escopo teórico de formação e o que se realiza no âmbito das escolas, mas que mesmo assim, trouxe contribuições em determinados aspectos para o modo de ser pedagogo e para a realização de seu ofício profissional.

O reconhecimento de ambigüidade que os gestores tecem acerca de sua profissionalização e profissionalidade nos remete a dizer que a qualidade presente nos cursos de formação dos pedagogos tem estreita relação com as possibilidades de reflexão acerca das alternativas para a resolução das situações-problema presentes na instituição escolar e nos sistemas educativos, embora os dados - tanto dos questionários como da estrutura curricular dos cursos - ainda apontem inúmeras limitações neste sentido.

Segundo os gestores participantes da pesquisa, alguns conteúdos presentes na sua formação inicial mostraram-se significativos para a organização e na realização da sua atividade profissional, destacando, no entanto, maior ênfase a conteúdos relacionados aos conceitos e fundamentos, e menos às práticas e dilemas da escola: 


\section{Conteúdos relevantes do Curso de Pedagogia para o trabalho de suporte pedagógico, segundo os gestores escolares}

\begin{tabular}{|l|l|l|}
\hline \multicolumn{1}{|c|}{ Professores Coordenadores } & \multicolumn{1}{|c|}{ Diretores de Escola } & \multicolumn{1}{c|}{ Supervisores de Ensino } \\
\hline - discussão sobre teorias da & - conhecimento sobre os & - conhecimento dos \\
aprendizagem; & fundamentos legais da educação & fundamentos legais da educação \\
- concepção de currículo; & brasileira; & brasileira; \\
- função da avaliação e dos & - diferentes aspectos presentes & - conhecimento dos principais \\
indicadores na escola; & na atividade de gestão escolar; & dispositivos legais relacionados \\
- papel do professor & - importância da valorização da & à organização do sistema \\
coordenador; & avaliação como instrumento de & educacional; \\
- finalidade da atividade & trabalho na escola; & - aproximação da supervisão \\
educativa na escola; & - o papel do diretor de escola na & escolar com as questões \\
- importância da alternância & mobilização para o trabalho & relacionadas à avaliação e ao \\
pedagógica na escola. & coletivo e a gestão de pessoas; & currículo escolar; \\
& - atuação do diretor de escola na & - papel do supervisor de ensino \\
& implementação do projeto & na proposição de ações de \\
& pedagógico da escola. & formação profissional. \\
\hline
\end{tabular}

Todos os diretores de escolas e supervisores de ensino ouvidos são formados em Pedagogia. Com relação aos professores-coordenadores, é interessante o fato de que os não pedagogos acreditam que o curso de Pedagogia poderia trazer ganhos na forma com que executam o seu trabalho. De acordo com seus depoimentos, se fizessem o referido curso desenvolveriam:

- Maior compreensão das questões trazidas tanto pelos professores como das propostas pela Secretaria, principalmente no que se refere à abordagem curricular ou à avaliação, que são temas altamente relevantes e pertinentes para a discussão nos HTPCs e momentos de formação continuada da equipe;

- Maior densidade na articulação do papel de professorcoordenador-pedagógico nas atividades que são efetivamente pedagógicas, evitando que involuntariamente se dediquem às atividades mais burocráticas e administrativas do cotidiano escolar; 
- Maior capacidade para a realização - de forma mais intensa e qualitativa - das ações e das discussões a respeito da prática pedagógica docente, uma vez que nas licenciaturas das áreas específicas de conhecimento estes conteúdos não são tidos como prioridades;

- Maior possibilidade de realizar a seleção de materiais e conteúdos formativos que estejam mais adequadamente articulados à formação de professores, inclusive do fortalecimento do seu potencial de discussão, de como estes aspectos são fundamentalmente pedagógicos;

- Maior possibilidade de aperfeiçoamento do discurso e dos argumentos pedagógicos que estão presentes em todas as ações de formação, sobretudo com a intenção de enfrentar a realidade de superação da dicotomia entre a teoria e a prática no trabalho docente e pedagógico.

Quando retomamos o desafio de garantir o desenvolvimento profissional e institucional nas escolas, valendo-nos das práticas compartilhadas de gestão, deparamo-nos com o fato destes precisarem atuar na perspectiva de uma cultura colaborativa e, neste caso, parece-nos fundamental que quanto mais intensa for a compreensão dos gestores acerca do trabalho dos professores, maior é a possibilidade de autenticidade do diálogo.

Entretanto, julgamos que, se a relação de gestão na escola é baseada também na validação das práticas e dos discursos, o fato de os gestores escolares terem sido docentes mostra-se como um diferencial substantivo na forma de realizar e pensar seu trabalho, portanto, ponderando a partir das discussões desta pesquisa, é desejável que o tenham sido.

Considerando as colaborações de Fullan \& Hargreaves (2001), acreditamos que os profissionais que atuam na escola se organizam alternativamente em diferentes formas (individualismo, colaboração, colegialidade artificial e a balcanização), alternativas mais ou menos eficazes para a mudança, como fenômenos que ocorrem porque os profissionais 
constroem as suas estratégias de trabalho interno, no caso da sala de aula e o ensinar, influenciados por colegas de trabalho na sua própria identidade profissional.

Tal processo é decorrente da cultura institucional que tem a ver com o "conteúdo e a forma" que caracterizam a organização do trabalho dos profissionais na instituição, ou seja, está diretamente ligado a como se realiza a gestão escolar, que é o instrumento de construção das práticas coletivas e dos diversos segmentos na escola.

Neste caso, a organização das formas de trabalho da instituição e o desenvolvimento da cultura institucional são aspectos que estão diretamente ligados à forma adotada em cada instituição na prática da gestão da escola e da concepção de educação de seus gestores, dado que as práticas decorrentes da gestão são resultantes de todo um conjunto de orientações, princípios e práticas destinadas à organização do funcionamento da instituição como instrumento de enfrentamento dos desafios e dos dilemas do cotidiano escolar, este voltado à construção de contratos colaborativos, como defendem Fullan e Hargreaves:

As culturas colaborativas reconhecem e dão voz ao propósito dos docentes. Ironicamente, nesse tipo de culturas, os desacordos são mais fortes e mais freqüentes do que noutras, pois os propósitos, os valores e a relação de ambos com a prática, são discutidos. Este desacordo torna-se possível devido à existência de uma base sólida de segurança fundamental em que se baseiam as relações entre os docentes - uma segurança que permite a discussão aberta e a discordância temporária, na certeza de que a continuidade das relações não será ameaçada. Nas culturas colaborativas, a análise dos valores e dos propósitos não se efectua num único momento (por exemplo, quando o pessoal docente participa na redaç̧ão da declaração da missão da escola) sendo, pelo contrário, um processo contínuo que abrange todo o estabelecimento de ensino. Todavia, as discordâncias também se tornam possíveis, porque existe um vasto acordo sobre os valores e as orientações fundamentais que os docentes desenvolvem e procuram concretizar ao longo do tempo. Nestas culturas, os propósitos não são inteiramente idiossincráticos, pois ganham grande parte da sua força com o facto de serem desenvolvidos e partilhados com os outros colegas (FULLAN; HARGREAVES, 2001, p.69).

A complexidade das formas de organização do trabalho escolar, que reflete a multiplicidade das formas e alternativas metodológicas de realização das atividades de gestão, tem como grande desafio romper com o isolamento 
entre o que acontece na sala de aula e o que ocorre nos demais espaços da escola.

O isolamento ao qual nos referimos decorre, na maioria das vezes, da criação de um pseudo status profissional, como se aos professores coubesse exercer a docência e garantir a aprendizagem dos alunos, e aos demais profissionais do magistério, que atuam na gestão, coubesse a coordenação do trabalho na escola através de diferentes ofícios, que supostamente seriam menos laboriosos do que ensinar, mais pautados em práticas burocráticas, desvinculadas do sentido pedagógico que deve ter uma escola plenamente pública.

Este contexto no qual os profissionais da escola se encontram numa relação mais aproximada da concorrência do que da colaboratividade, demonstra a forma inescrupulosa e egoísta que vai sendo incorporada tanto de professores como de gestores em relação ao modo de como se identificam uns com os outros, refletindo os efeitos perversos do controle externo que Ihes é imposto, da ausência de condições de melhoria de suas práticas mediadas pelo local de trabalho, além do constante processo de expropriação da autonomia destes profissionais, fazendo dessa resistência um modo de se protegerem em relação às críticas e às interferências internas e externas quando se sentem frágeis diante dos contextos.

Esta dualidade na forma prática de ver o trabalho dos pedagogos na escola não deixa de ser certa forma de concretização da desconfiança sobre a reciprocidade que deve haver entre os pedagogos, que atuam na docência, e os pedagogos, que atuam como gestores, num processo contínuo e permanente de relações entre os sujeitos, o qual implica em possíveis formas de interlocuções que sistematizamos nas análises da dissertação de mestrado $^{72}$ que desenvolvemos entre 2004 e 2007.

\footnotetext{
72 Esquema de nossa autoria, construído a partir dos depoimentos dos participantes da pesquisa de mestrado que desenvolvemos sob orientação da Profa. Dra. Maria Isabel de Almeida, junto à Faculdade de Educação da Universidade de São Paulo (2007), intitulada: "A profissionalidade dos supervisores de ensino da rede estadual paulista: interfaces com os fazeres escolares". Na ocasião, nos dedicamos a demonstrar as variáveis relações entre os supervisores de ensino e a escola. Entretanto os dados que coletamos na atual pesquisa corroboram a afirmação que as relações entre os gestores escolares e os docentes também
} 
Vale ressaltar que na pesquisa realizada, investigamos o caso da supervisão de ensino, de modo geral, mas finalizamos a hipótese de que algumas de suas considerações podem ser ampliadas para as demais situações de ofícios de gestão escolar e entre os professores.

As análises demonstraram que os modos pelos quais as relações de diálogo e poder se constituem entre os gestores escolares e os demais sujeitos da escola são resultantes da perspectiva de trabalho que se constrói em cada unidade e é fator determinante no fortalecimento de pactos e de projetos colaborativos que contemplam as necessidades de diferentes segmentos da escola. Sugerindo assim as seguintes estruturas de relação:

Tendências identificadas nas relações de poder entre a escola (E) e a Supervisão (S)
1) $\mathrm{E}$

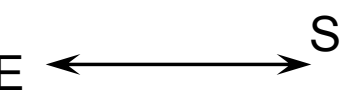
A escola autoritariamente influenciada pela Supervisão.
Escola determinando a ação da
2) Supervisão.

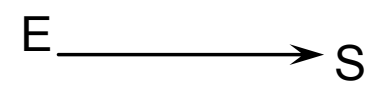
3)

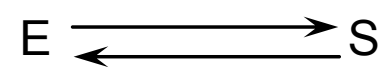
Diálogo construtivo e formativo entre a escola e a Supervisão.
4) Supervisão ausente e omissa em relação à escola.

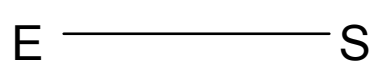
5) $\mathrm{E}$ desorientando a escola. permite deduzir algumas características do processo de gestão na unidade. 
6) Escola ora indiferente, e ora inalterada em relação à ação Supervisora.

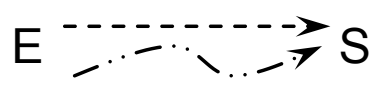
$\mathrm{E} \Longleftrightarrow \mathrm{S}$ A relação entre a Supervisão e a escola é dialógica, 7) visando uma prática pedagógica crítica e reflexiva.

Quadro 1: Organizado a partir dos depoimentos de Professores e Professores-Coordenadores e Diretores sobre a relação de trabalho com os supervisores de ensino.

As relações apresentadas no quadro anterior reiteram, a partir dos dados desta pesquisa, que a relação de poder estabelecida entre aqueles que realizam a atividade educativa no espaço escolar está diretamente ligada às formas como são construídos os mecanismos de regulação do trabalho institucional e a relação que se estabelece com as políticas do sistema.

Portanto, podemos sugerir com propriedade que tais relações são resultantes da forma de gestão desenvolvida. Quanto mais autêntica e dialógica for a forma de gestão da escola, maiores serão as possibilidades de se dar visibilidade à cultura da escola e às suas demandas, necessidades e avanços, contemplando seu papel na construção da democracia cidadã.

Consideramos que a matriz de saberes que orientará a profissionalidade e a profissionalização dos gestores escolares, deve ser colocada como prioridade, pois entendemos que o processo de formação inicial, neste caso no curso de Pedagogia, está diretamente ligado aos conhecimentos e instrumentos iniciais utilizados pelos gestores para a organização do seu fazer.

É certo que devido ao tempo de atuação profissional as experiências vão incorporando elementos cotidianos da prática, que são capazes de atribuir valores sobre os saberes teóricos inicialmente apresentados.

Assim, destacaríamos que a formação de tais profissionais, nos cursos de Pedagogia, se coloca como determinante para a construção de um modo de gestão voltado ao controle do trabalho, às práticas procedimentais e ao 
funcionamento eficaz da rotina; ou desejavelmente outro modo de gestão que priorize o desenvolvimento profissional e institucional: a atuação pela resolução de problemas, a mobilização da dimensão coletiva de trabalho diante da ação colaborativa, dentre outras características, sob uma prática conscientemente crítica mediada pelo projeto pedagógico da escola.

Reafirmamos aqui as proposições de Paro (2010) ao defender que o pressuposto de gestão mais amparado em princípios progressistas e democráticos não garante por si só o bom funcionamento institucional, ou o alcance de bons resultados, ou ainda um espaço que assegure os interesses, mesmo que genuínos de alguns de seus segmentos. Argumenta o autor que para tanto é necessário um conjunto de práticas exercidas por sujeitos, comprometidos com o propósito social e político de emancipação e autonomia que deve ter a escola, e isto está diretamente ligado à forma de realização da gestão do trabalho educativo e escolar:

\begin{abstract}
Embora não seja este o lugar para discutir com detalhe toda uma nova concepção de organização da escola que contemple sua natureza necessariamente democrática, parece importante ressaltar um aspecto que precisa obrigatoriamente ser levado em conta num projeto de reestruturação da escola que tenha tal escopo. Não basta, como tem usualmente acontecido, lutar pelo atendimento dos direitos e interesses (legítimos) de cada um dos vários setores da escola (professores, funcionários não docentes, corpo discente, pais e comunidade em geral), embora isso também deva estar em pauta. É preciso que o objetivo final que oriente a democratização seja o aluno e o desenvolvimento de sua autonomia, pois o fim de uma escola democrática é precisamente a formação de personalidades humano-históricas em seus alunos (PARO, 2010, p.68).
\end{abstract}

A atribuição de importância ao curso de Pedagogia na formação dos gestores escolares se reafirma, sobretudo quando reconhecemos que este pode ser o locus de articulação das diferentes categorias dos saberes que constituem a atuação profissional dos pedagogos nestas atividades.

É nesta perspectiva de diversificação de saberes que Dubar (2003) entende as maneiras pelas quais se designam os saberes necessários à realização exitosa do trabalho como resultante da atividade em um determinado ofício, o que nos leva também a defender que o trabalho dos 
gestores escolares não é essencialmente prático, nem exclusivamente teórico, e nem tampouco se baseia apenas em procedimentos técnicos.

Ao considerarmos estas categorias de saberes que se fazem presentes na realização do trabalho, podemos sugerir que o profissionalismo é constituído por conhecimentos derivados de diferentes campos de saberes, o que exige uma formação rigorosa e complexa, podendo-se destacar:

a) para a corrente que valoriza os saberes práticos, a formação precisa estar fundada no fazer e baseada profundamente nas questões concretas do oficio, concepção que pode provocar certa desvalorização do conhecimento "escolar", definindo como melhoria o desempenho mais qualificado em relação ao "que fazem";

b) para a corrente que aprecia os saberes teóricos orienta-se pela relação com a competência acadêmica que os profissionais detêm. Esta formação baseia-se em pressupostos mais enciclopédicos acerca do ofício, valorizando o ensino como uma forma de melhoria do desempenho profissional;

c) há ainda aqueles que acreditam na dominância dos saberes técnicos e colocam os saberes da ciência em função da resolução de problemas da prática, não sendo nem indutiva (como para os práticos), nem dedutiva (como para os teóricos). Estes acreditam que a experiência é um aspecto de orientação para o trabalho com melhores resultados e vinculam diretamente 0 trabalho e a ciência; e

d) os que definem a formação como uma maneira de aquisição de saberes da organização, alternativa que entende que as três dimensões anteriores precisam ser integradas e internalizadas pelo sujeito e que, portanto, estão diretamente vinculados aos valores políticos que orientam a tendência profissional para a qual se credita maior valor e pertinência em relação ao que se deseja alcançar.

Os questionários respondidos pelos gestores escolares demonstram que os fazeres que eles desempenham em sua atividade profissional, para que sejam realizados com maior grau de eficácia, exige que sejam capazes de 
articular estes saberes que procuramos apresentar anteriormente em quatro categorias.

Entretanto, afirmam que grande parte dos conhecimentos adquiridos em sua formação inicial não contempla esta abordagem mais sistêmica que abranja diferentes categorias dos conhecimentos que sustentam a realização do trabalho, apontando que na maioria das experiências formativas, os conhecimentos priorizados podem ser vinculados aos saberes teóricos ou técnicos, em detrimento das categorias prática e de organização, como aprofundaremos no próximo capítulo.

Assim sendo, almejamos inferir que pensar na gestão do trabalho da escola, confere-nos o dever de superar a visão pragmática que compreende a profissão docente como eminentemente prática, isoladamente teórica, ou ainda, "a serviço" da resolução de problemas determinados por sujeitos ou por organismos definitivamente externos a ela.

A gestão da escola é uma atividade que exige um processo de aprofundamento na forma de trabalho das escolas, articulando, ao mesmo tempo, a intensidade do pensamento teórico sobre o que orienta nossas decisões e os fazeres práticos, que caracterizam a nossa atuação.

As condições nas quais os gestores escolares atuam no desenvolvimento de ações em suas escolas são realmente marcadas por contradições e carecem de elementos conjunturais, que se configurem como suporte efetivo ao seu trabalho.

Segundo os sujeitos desta pesquisa, há um descolamento permanente entre as competências anunciadas como fundamentais para o trabalho, as capacidades e habilidades provocadas durante os cursos de formação dos gestores e, principalmente, o que são compelidos a realizar no cotidiano de trabalho, mediante condições bastante adversas, uma forma de profanação do trabalho docente.

Conforme Nóvoa (1995), para que a profissionalização seja mais exitosa é necessário que haja atuação em tempo integral (o que implica em condições 
de carreira para a desnecessidade de acúmulo de funções), suporte legal para o exercício cotidiano do ofício, criação de instituições específicas para a formação de professores e constituição de associações profissionais. Considerando-se o que temos no Brasil, podemos identificar que vários destes elementos estruturam-se com considerável fragilidade.

Pelos elementos que apresentamos anteriormente, além das contribuições trazidas por Day (2001), evidencia-se que os ofícios dos profissionais do magistério passam por indagações, uma vez que a definição do "ser profissional" vem sofrendo em decorrência de situações paradoxais, uma vez que as virtudes no campo da educação, como a ampliação do atendimento da quase totalidade da população na educação básica, se agrega a medidas tecnocráticas, como a imposição de sistemas de avaliação externos, controle de financiamento e determinação do currículo pelas agências estatais.

Com efeito, a idéia de "profissionalismo" também passa por mudanças, enquanto alguns pesquisadores afirmam que existe um aumento da autonomia, entre eles Hargreaves (1994), Thurler (2001), Perrenoud (2006), Luck (2008); outros, como Contreras (2002), Garcia (2004), Libâneo (2005) e Paro (2010) compreendem que o que se intensifica é a ruptura entre o desenvolvimento profissional e o desenvolvimento institucional, principalmente pela intensificação das práticas de controle sobre o funcionamento da escola pública e o exercício da profissão docente.

No capítulo III desta pesquisa, iremos tratar justamente de como os cursos de Pedagogia, ora responsáveis pela formação inicial dos gestores escolares, têm apontado e proposto alternativas para uma abordagem desta constituição profissional que é extremamente complexa, que exige competências de diferentes naturezas, que possam contribuir para o desenvolvimento profissional dos sujeitos da escola e para o desenvolvimento institucional da escola.

Neste caso, o intuito é analisar em que medida os cursos de formação corroboram esta concepção de gestão escolar que temos apresentado e que possibilidades de formação dos gestores sugerem em suas estruturas curriculares. 
Se o desenvolvimento profissional for perseguido, a profissionalidade ampla toma lugar de uma espécie de profissionalidade restrita, favorecendo o fortalecimento do grau de autonomia, consciência e reflexão com as quais estes profissionais construirão juízo de valor acerca de sua própria prática e a dos demais como forma de resistência ao aumento do controle burocrático, não se bastando, portanto, o domínio de conteúdos compartimentados ou aquisição de habilitações fragmentadas, em que pese os saberes mais especificamente necessários para a realização de cada uma das atividades de gestão da escola.

A formação de professores e, neste caso, de gestores escolares colocase como um dos maiores desafios e, ao mesmo tempo, uma das maiores virtudes no enfrentamento das circunstâncias que envolvem o trabalho dos formadores que atuam em atividades de coordenação, direção e supervisão do trabalho pedagógico.

Presumimos que os saberes dos gestores escolares precisam ser contextualizados na sua ação para que se tornem elementos autênticos de formação. Isto implica em ser também necessária uma formação para tais profissionais durante o processo pedagógico das escolas, articulando os diferentes saberes enunciados, os contextos da prática e as expectativas de resultados do ofício. 


\section{CAPÍTULO III}

\section{Da formação inicial e profissionalidade dos gestores escolares: possibilidades de desenvolvimento institucional}

Neste capítulo, analisaremos mais detalhadamente os dados nos quais apoiamos a pesquisa, com base na organização curricular dos cursos de Pedagogia, e considerando o que julgamos como elementos formativos relevantes para os egressos que atuarão no campo da gestão pedagógica. Assim, o objetivo é destacar os elementos do currículo que podem contribuir para a superação de certa "identidade perdida", que transita entre a formação para a gestão baseada num relativo especialismo "de um pouco", ou a do gestor "de um tudo", ambos em situação complexa no contexto da escola.

Segundo Dubar (1997), do ponto de vista da identidade social, um dos processos mais significativos na construção da identidade profissional é a saída do sistema acadêmico para a entrada no mundo do trabalho, momento no qual terá que lidar com suas percepções de mundo, suas capacidades e características, suas expectativas de trajetória profissional, as exigências do mundo do profissional e o coletivo mediado pelo trabalho.

Neste momento da história de vida dos sujeitos, também ocorre a legitimação relacional com os processos de trabalho, com outros indivíduos e com as organizações, ou seja, é um movimento praticamente historiográfico, entre sujeito e contexto, forjando seu "novo ser", sua identidade diante da profissão.

Em nosso entendimento, é possível que neste cenário, a identidade dos professores seja construída de forma apoiada por outros profissionais, ou que relegados ao risco de isolamento na escola, sofram do "choque de realidade", que tornará sua introdução e permanência na carreira muito mais árdua, indesejável e incongruente aos propósitos desejáveis do trabalho educativo. 
Esta proposta de análise das matrizes curriculares dos cursos de Pedagogia combinada com as necessidades que os pedagogos apontaram nos questionários acerca do seu trabalho, e como lidam com as mesmas a partir de sua formação, espera indicar possíveis alternativas para a superação de uma profissionalização relativamente degradada, de maneira a nos dedicarmos a alternativa mais integradora, que possibilite uma compreensão mais sistêmica da cultura escolar e da cultura da escola.

Trata-se, portanto, de analisar a atual proposta de formação destes profissionais, não para indicarmos se eles refletem ou não sobre a prática, apenas, mas sim de que modo refletem sobre o seu trabalho, e no que se apoiam para a sua profissionalidade.

O cenário que já antecipamos é que no período pós Lei 9394/96, os cursos de Pedagogia, aderiram a um processo de inclusão de uma série de "disciplinas curriculares", como se tal pulverização de conteúdos, sem a definição de uma identidade para estes profissionais, fosse suficiente para o atendimento do previsto no artigo 64 da própria lei.

Neste sentido, apontaremos quais as convergências entre a formação inicial oferecida aos gestores e os desafios vividos por estes profissionais no sentido de contribuírem para o desenvolvimento institucional, considerando se o que vivemos é uma situação de muitos olhares formativos possíveis em relação ao que se faz, ou uma "colcha de retalhos", no que tange às idéias pedagógicas.

Partimos do pressuposto de que, se não há vinculação entre a profissionalização, ainda que inicial, e a profissionalidade dos sujeitos, ocorre de fato a ampliação do discurso que insiste na ruptura entre a teoria e a prática, como se a primeira se estruturasse apenas no plano das idéias, enquanto que a segunda se assentasse num terreno esgotado de alternativas de ação para a melhoria do trabalho institucional, condição esta que contribui severamente para o processo de desprofissionalização e o afastamento de um profissionalismo que não pode apenas ser técnico, nem tampouco apenas 
prático, se o propósito for o desenvolvimento da autonomia da escola e a atuação intelectual e reflexiva dos profissionais.

Analisarmos os cursos e também o que afirmam os professores coordenadores pedagógicos, diretores de escola e supervisores de ensino situa-se na concepção pela qual entendemos que não se aplica o princípio de primeiro se pensar e formar-se, para depois viver e fazer na escola, uma vez que tais profissionais, se já imersos no contexto educativo vivenciam a organização da escola, e portanto o local de trabalho e conteúdo desta própria profissionalização, logo não pode ser preterida no processo.

Se uma das grandes tarefas dos profissionais que atuam nas atividades de gestão escolar é a de entender e agir na escola numa perspectiva mais ampla, considerando sua complexidade, as análises que aqui faremos se reportarão ao que precisam ter para esta tarefa, e como os cursos de formação podem corroborar a esta perspectiva. Será que os próprios profissionais se vêem como competentes para esta tarefa? Ou seja, em que medida sua formação contribuiu para pensarem e organizarem sua profissionalidade também para o desenvolvimento institucional?

Ao elegermos a concepção de desenvolvimento institucional como referência de trabalho para os gestores escolares, defendemos um modo de se pensar e agir sobre a escola que se coloque a serviço da construção de uma educação de qualidade essencialmente social, pela qual se estabeleçam compromissos profissionais e pedagógicos claros, e que portanto se efetivem por uma ação profissional que não seja fragmentada, possibilitando a construção de saberes profissionais a partir da práxis, e daí a importância do que trazem da sua formação inicial para a organização de seu trabalho.

Como anunciado no método da pesquisa, a multirreferencialidade de elementos a serem analisados pode ser esquematizada da seguinte forma: 


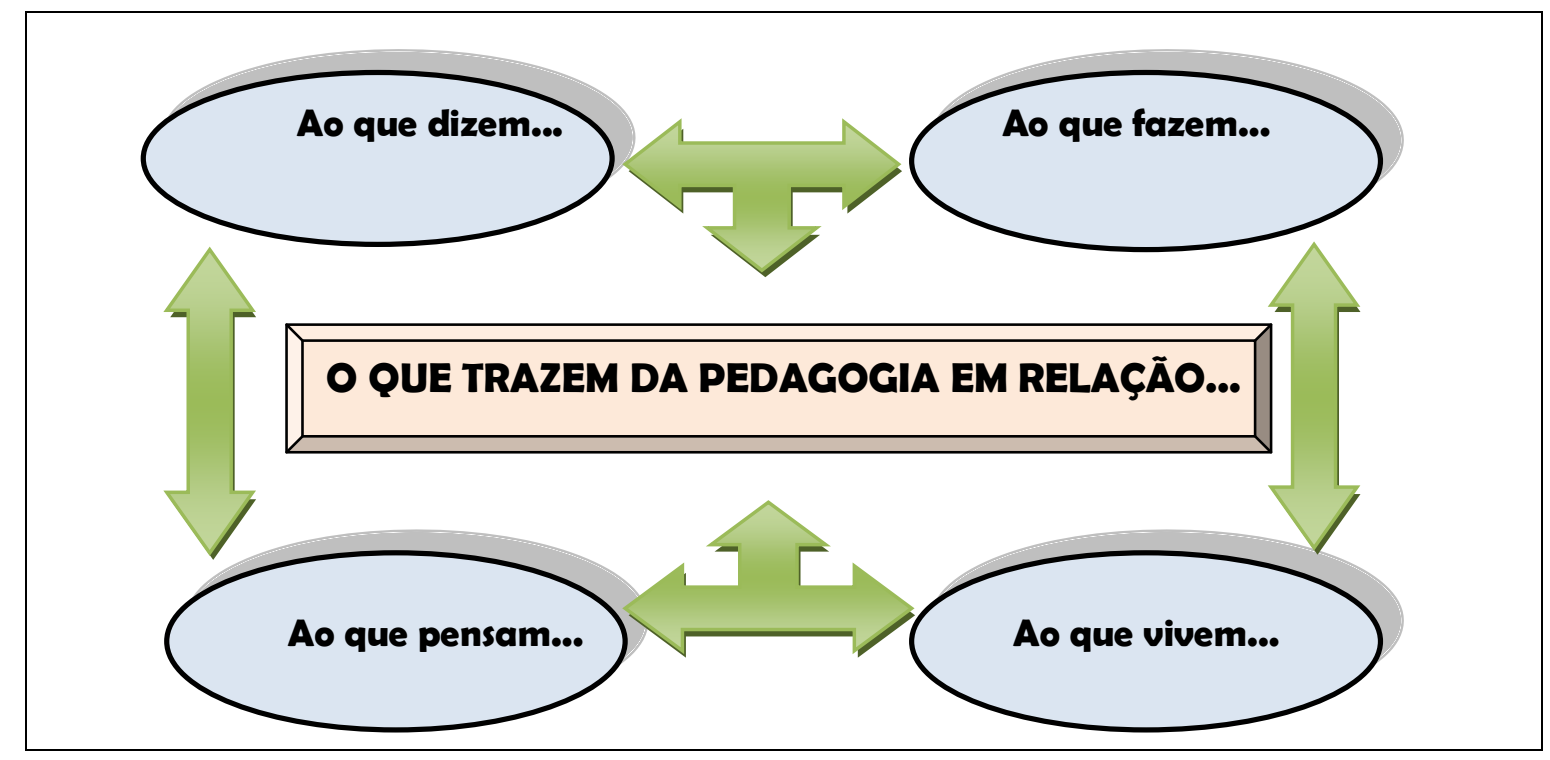

A partir destes elementos será elaborada a conclusão da pesquisa, assim como apontamentos considerados necessários em relação à organização dos cursos de Pedagogia, voltada também à formação dos gestores escolares, além de outros campos de atuação, de modo que contemplem mais efetivamente esta área de atuação do pedagogo, superando a condição de um relativo "complemento" oferecido ao longo do curso.

\subsection{A proposta de formação para os gestores escolares: o que trazem os cursos de Pedagogia}

A partir deste momento apresentaremos algumas análises acerca da tendência apresentada pelos cursos de Pedagogia no Brasil, no que se refere à formação inicial dos profissionais que atuarão como gestores escolares nas atividades de suporte pedagógico.

Não obstante a prerrogativa legal de destaque para a formação docente em tais cursos, no caso desta pesquisa, nos deteremos na construção dos elementos que apontam as possíveis aproximações que estão previstas no 
curso com as atividades de gestão na escola, principalmente, considerando que ser gestor escolar pressupõe a experiência docente ${ }^{73}$.

Nesta perspectiva, em muitos casos, os egressos da Pedagogia, já tecem algumas aproximações acerca de como se efetiva o exercício destas atividades profissionais.

Embora a formação dos gestores escolares ocorra também pelas experiências vividas no contexto da escola, espaço no qual enfrentará, mesmo enquanto docente, os dilemas da organização do seu trabalho, do trabalho coletivo, da organização da escola e da articulação institucional, entendemos que na formação inicial pode existir a oportunidade de uma compreensão antecipada acerca do sentido da existência dos gestores escolares, vislumbrando a atuação do pedagogo para além da docência, em campos mais específicos do trabalho pedagógico.

Por reconhecer na formação inicial uma etapa fundamental da profissionalização dos sujeitos, à medida que pode apresentar-lhes de forma mais sistematizada conteúdos formativos mais significativos, ou não, para o início do exercício profissional, a análise que apresentamos para a construção da tese desta pesquisa se fundamenta nas tendências apresentadas pelos currículos dos cursos de Pedagogia, como indicação de qual trajetória de formação dos gestores é oferecida aos egressos.

A partir da análise das matrizes curriculares dos 130 cursos de Pedagogia, identificamos que nos cursos das instituições públicas (33), a formação inicial para a atuação no campo da gestão escolar e educacional apresenta-se em torno de 4 a 11 disciplinas em todo o curso, sendo que em apenas $22 \%$ destes cursos tais conteúdos são priorizados em menos de 4

\footnotetext{
${ }^{73}$ Conforme levantamos nos estudos realizados nesta pesquisa, há predominantemente nos sistemas educacionais brasileiros a exigência da experiência docente como exigência para o exercício de atividades de suporte pedagógico, variando, contudo o tempo requerido de experiência para cada um dos ofícios, e também em cada sistema, mesmo quando tratamos de redes estaduais e municipais da mesma unidade federativa.
} 
disciplinas durante toda a formação, enquanto que em cerca de $54 \%$ dos cursos são oferecidas ao menos 7 disciplinas vinculadas à formação para a gestão escolar $^{74}$.

Quando tratamos de analisar os cursos das instituições privadas (97), identificamos que a mesma formação ocorre essencialmente no trabalho de 2 a 8 disciplinas que compõem o curso, sendo que em $65 \%$ dos cursos analisados tais conteúdos são priorizados em até 5 disciplinas; apenas 10\% destes oferecem 7 ou mais disciplinas vinculadas diretamente à formação do gestor.

Apesar deste indicador apresentar evidências mais quantitativas, há de se considerar que existe em muitos cursos uma presença um tanto quanto superficial dos conteúdos da formação do gestor, a qual ocorre em momentos bastante pontuais do curso, inviabilizando a discussão permanente do trabalho nesta perspectiva, além de desfavorecer a articulação dos conteúdos gerais do curso com aqueles mais pertinentes à atuação do gestor.

A existência desta quantidade de disciplinas nos cursos destaca a formação inicial dos gestores escolares nos cursos de Pedagogia num período um tanto quanto restrito num processo de formação que ocorre integralmente entre 6 a 8 semestres, provocando, não raramente, que os conteúdos deste campo de atuação do pedagogo fiquem relegados a momentos isolados.

Constatamos que a formação mais dedicada aos conteúdos de formação dos gestores escolares ocorre de 2 a 4 semestres dos cursos de Pedagogia, sendo que em $78 \%$ das instituições públicas ocorre num período que varia entre 3 a 4 semestres do curso, com a carga horária entre 60 e 80 horas nestas

\footnotetext{
${ }^{74}$ A literatura educacional mais recente tem se referido à nomenclatura gestor escolar na tentativa de se afastar das habilitações vigentes até 2006 e que adotava a nomenclatura de especialistas em educação. Sem embargo das implicações teóricas que já tratamos nesta pesquisa, o que nos parece mais relevante não é o fato de que o profissional seja mais especialista em um determinado campo de atuação, como naturalmente ocorre após algum tempo de experiência, mas que a condição de especialista em determinado ofício, não o leve à uma visão parcial do trabalho relacionado à organização da escola ou sua profissionalidade, provocando desconhecimento ou impotência em relação à diversidade das atividades.
} 
disciplinas. Nestas, em $22 \%$ dos cursos, as disciplinas são oferecidas em mais de 4 semestres do curso, chegando quando muito a 6 semestres de todo 0 curso.

Em cursos de instituições privadas, esta formação é priorizada no período de 2 a 3 semestres, em cerca de 44\% dos cursos, com carga horária que varia entre 40 e 80 horas em cada disciplina. Em cerca de $38 \%$ dos cursos privados são oferecidas mais de 4 disciplinas para a formação dos gestores.

As disciplinas que se dedicam mais intensamente aos conteúdos de formação dos gestores escolares se concentram nos últimos semestres do curso, o que reforça a concepção de que a gestão escolar é um campo de atuação na maioria das vezes concebido como de "fechamento" da formação, ocorrendo quase que de maneira paralela aos demais campos de atuação dos egressos do curso de Pedagogia.

Fica também demonstrada a idéia equivocada de que os conteúdos da gestão escolar são mais complexos do que a docência ou a própria atuação do pedagogo e que em decorrência disso, devem ser apresentados ao final do curso, o que está em desacordo com o pressuposto de que todos os conteúdos formativos são dotados de seu sentido acadêmico, científico, intelectual e técnico, e desta forma articulam-se.

Mesmo num contexto no qual existem muitas pesquisas acerca da identidade do pedagogo e conseqüentemente, a efetiva qualidade dos seus cursos de formação inicial, como uma forma de se buscar respostas mais propositivas para o cenário complexo da escola.

Constatamos que na maioria dos cursos, permanece uma formação baseada no oferecimento de disciplinas mais generalistas e tradicionais no campo da gestão escolar, que já foram inauguradas no curso de Pedagogia desde o Parecer CFE 252/69 como, por exemplo, Política ou Legislação 
Educacional, Gestão Escolar ou Educacional, Estrutura e Funcionamento da Educação e Organização da Educação Básica.

Em 48 cursos analisados, a formação do pedagogo com foco na gestão escolar está centrada basicamente nestas disciplinas, sendo que $74 \%$ destes cursos estão em instituições privadas. Conquanto estas disciplinas estejam presentes em $85 \%$ dos cursos oferecidos por instituições privadas, fato este que isoladamente não representa nenhum entrave na formação, identificamos algumas "disciplinas complementares" na perspectiva deste campo de atuação.

Outro aspecto que traz indício de um relativo afastamento da formação do gestor escolar no âmbito dos cursos de Pedagogia é a ausência da discussão da própria ciência pedagógica, ou mesmo da identidade do pedagogo, inclusive no que se refere à identidade do professor, existindo mais intensamente a discussão de aspectos metodológicos e práticos relacionados ao trabalho do pedagogo que atua predominantemente na docência.

Nota-se, portanto, que mesmo ao atender a Resolução CNE CP 1/06, a qual prescreve o foco na formação para a docência, há uma condição rarefeita no que se refere ao sentido político e pedagógico da existência destes profissionais, o que se manifesta ainda mais quando tratamos da gestão escolar, muito em razão do tratamento atribuído nos cursos de Pedagogia.

Constatamos que em muitos casos, mais exatamente em 92 dos 130 cursos analisados, são propostas disciplinas como Avaliação, Planejamento ou Currículo como correlatas à formação do gestor escolar ${ }^{75}$, o que é real, caso

\footnotetext{
${ }^{75}$ Mesmo considerando apenas como uma normatização legal, ao menos em princípio, em fevereiro de 2012, o Conselho Estadual de Educação do Estado de São Paulo publicou a Deliberação CEE 111/12, que apresentou novos dispositivos para a regulamentação da formação dos profissionais da educação básica, formados nos cursos de Pedagogia, indicando no inciso IV do artigo $4^{\circ}$, que ao menos 400 horas dos cursos deverão ser destinadas à formação dos docentes para a atuação em outros campos de trabalho, conforme previsto na Resolução CNE CP 01/06. A mesma deliberação estabelece que minimamente 100 horas destinadas ao estágio supervisionado deverão ser realizadas junto ao acompanhamento de atividades de gestão escolar e educacional. Esta regulamentação pontual da norma nacional indica, ainda que restritivamente às instituições vinculadas ao sistema estadual de ensino, a
} 
não fossem tratadas com foco essencialmente na docência, mas se apontassem o papel dos futuros gestores na organização de práticas escolares que contemplem estes aspectos.

Em não havendo esta abordagem nestas disciplinas do curso de Pedagogia, corre-se o risco de ampliar a desvalorização do papel dos gestores na construção destes aspectos no projeto da escola, implicando numa inversão do propósito de conceber as atividades dos profissionais da gestão escolar como meio para a melhoria da avaliação, currículo ou do planejamento da escola, e não uma perspectiva de fim, que intenciona demonstrar equivocadamente que "a escola é a cara de seus gestores".

Esta situação se mostra também muito presente quando constatamos que em cerca de $46 \%$ dos cursos, as disciplinas mais convencionais para esta formação mais pedagógica são supostamente complementadas apenas com uma outra normalmente denominada de Gestão do Trabalho Pedagógico, indicando a ilusória preparação para lidar com "este conteúdo", como se não fosse a razão da existência da gestão na escola, supondo-se que suas concepções e representações são necessariamente responsáveis pelo que ocorre na escola.

Podemos também inferir que esta forma de apresentação dos conteúdos acerca da profissionalidade e da profissionalização dos gestores escolares é decorrente da própria condição de busca da identidade para o curso de Pedagogia, como espaço formativo que deve, a priori, estabelecer suas prioridades conceituais, científicas e epistemológicas, de modo que não permaneça uma situação na qual a presença da pluralidade curricular é tão grande que se configura como indefinição do propósito específico do que se deseja.

possível fragilidade, ou excessiva flexibilidade, para a formação dos gestores escolares nos atuais cursos de Pedagogia. 
Para situarmos esta percepção acerca do que entendemos como pluralidade excessiva nos currículos dos cursos de Pedagogia, que dificulta a compreensão clara e objetiva "do que e como se quer formar", e também do "espaço" restante a ser atribuído à formação dos gestores escolares, apontamos, por exemplo, a multiplicidade de disciplinas encontradas nos cursos.

Estas tantas disciplinas do curso de Pedagogia, de modo geral, apresentam vínculo mais efetivo com outros campos de atuação, ou mesmo que requerem um maior aprofundamento ou continuidade de estudos, sob o risco de se tornarem apenas "ensaios de aprendizagem", num curso que deve dar conta de tantos outros aspectos específicos de atuação do pedagogo.

Neste caso, ilustramos a seguir esta gama de disciplinas, apontando como exemplos, o que acontece com propostas mais vinculadas propriamente à área da saúde, das artes, do corpo, da sociologia, das tecnologias.

Não se trata de refutarmos a importância da abordagem de conteúdos estritamente de ensino e aprendizagem, mas de perceber que uma formação própria para o pedagogo, já difícil de ser alcançada em tempo restrito, corre o risco de maior aligeiramento quanto a tantas diversidades, como podemos notar: 


\section{Disciplinas diversas nos cursos de Pedagogia}

\begin{tabular}{|c|c|c|}
\hline Artes & $\Rightarrow$ & $\begin{array}{l}\text { Educação Musical, Teatro, Teatro e Música, } \\
\text { Psicodrama, Consciência do Corpo, Socionomia e } \\
\text { Psicodrama. }\end{array}$ \\
\hline Tecnologia & $\Longrightarrow$ & $\begin{array}{l}\text { Vídeo e Educação, Produção de Vídeo na Escola, } \\
\text { Radio e Televisão, Multimídias educacionais e EaD. }\end{array}$ \\
\hline Sociologia & $\Longrightarrow$ & $\begin{array}{l}\text { Relações Humanas, Direitos Humanos e Educação, } \\
\text { Educação Ética e Estética, Educação em Direitos } \\
\text { Humanos, Movimento Social e Prática Pedagógica, } \\
\text { Economia Política. }\end{array}$ \\
\hline Saúde e Ciências & & $\begin{array}{l}\text { Neurofisiologia, Psicopedagogia, Nutrição, } \\
\text { Psicolinguística, Psicanálise e Educação, Educação } \\
\text { e sexualidade, Neurociências e desenvolvimento do } \\
\text { cérebro, Ecopedagogia. }\end{array}$ \\
\hline Questões Sociais & $\Rightarrow$ & $\begin{array}{l}\text { Educação para grupos populares, Educação do } \\
\text { Campo, Educação para a Terceira Idade, Cultura } \\
\text { Afro Brasileira, Movimentos Sociais e Educação. }\end{array}$ \\
\hline
\end{tabular}

É notável a impressão de que muitos conhecimentos de natureza mais específicos tornam-se compatíveis para a incorporação ao currículo da Pedagogia apenas com a inclusão da expressão "educação"76. Neste caso, conteúdos, práticas, processos sociais e até ciências mais específicas ocupam

${ }^{76}$ O quadro que ora apresentamos, demonstra a interpretação exagerada do artigo $2^{\circ}$ da Resolução CNE CP 01/06, ao prever que a formação e o currículo de Pedagogia contemplariam os diferentes campos de atuação do pedagogo e dos demais campos de atuação que do conhecimento pedagógico se valerem, como cita: "As Diretrizes Curriculares para o curso de Pedagogia aplicam-se à formação inicial para o exercício da docência na Educação Infantil e nos anos iniciais do Ensino Fundamental, nos cursos de Ensino Médio, na modalidade Normal, e em cursos de Educação Profissional na área de serviços e apoio escolar, bem como em outras áreas nas quais sejam previstos conhecimentos pedagógicos". Ora, dada a amplitude da necessidade de conhecimentos pedagógicos, ou minimamente de um olhar que se aproxime do reconhecimento da condição humana para aprender, ensinar e produzir conhecimentos, há de se reconhecer que toda a atividade humana também se circunscreve por relações também pedagógicas, ainda que não necessariamente escolares, ou docentes. Contemplar todas estas possibilidades em um curso de formação já seria tarefa impossível, ainda mais em cursos que se encontram em tempos de duração incontestadamente suprimidos. 
espaço nos cursos, sob o discurso de estarem a serviço da educação, ou pela educação se servir destas, o que nos obriga a um currículo infinito, dada a amplitude do ato educativo.

Como já antecipamos, o relativo isolamento destinado à formação do pedagogo com vistas a atuarem dentro de campos específicos do trabalho pedagógico na escola, no caso da gestão, é resultante da combinação de vários fatores, dentre os quais: reduzida carga horária, oferecimento basicamente em períodos finais do curso, escassez de disciplinas que contemplem os diferentes aspectos da gestão e da profissionalidade dos gestores em diferentes ofícios, dentre outros.

Conseqüentemente, permanece um notório conservadorismo na organização curricular e na proposta de formação destes profissionais no âmbito dos atuais cursos de Pedagogia.

Segundo constatamos em pesquisa, $42 \%$ dos cursos sustentam os conteúdos formativos para estes ofícios, através da disciplina Gestão Escolar, mantendo conteúdos que discutem com maior ênfase as práticas da administração escolar. Isso ratifica que há um discurso que anuncia a demanda por novas formas de organizar e embalar o trabalho da escola.

Entretanto, permanece ainda uma realidade de oferecer instrumentos clássicos ou remotos desta prática, mesmo que sob nova roupagem teórica, creditando ao Diretor de Escola maior responsabilidade em relação ao desenvolvimento da escola.

Constamos, a partir das matrizes curriculares analisadas, que apenas nestes cursos existem mais de 50 nomenclaturas atribuídas à disciplina, indicando alguma tendência no trabalho a ser desenvolvido no programa da disciplina, sendo a mesma o espaço mais intensivo na abordagem dos conteúdos para a formação dos gestores escolares. 
O fato que apresentamos anteriormente resulta da desarticulação ao se discutir o ato pedagógico propriamente em sala de aula, que emana da ação entre alunos e professores, e o ato pedagógico que precisa fundamentar toda a ação educativa na escola, e porquanto, de todos os seus profissionais e em todas as suas práticas, considerando que na escola, pedagógico deve ser tanto o ato de trabalho, como o ambiente integralmente.

Esta inversão na maneira de os cursos formarem os pedagogos ressoa também na confusão relacionada à dimensão conceitual de gestão escolar, gestão educacional e gestão pedagógica, como se tratássemos de sujeitos com a mesma profissionalidade, embora existam convergências, ou de atividades com as mesmas finalidades e atributos nos sistemas de educação.

Os elementos que coletamos pelas matrizes curriculares dos cursos corroboram o entendimento de que a gama de adjetivos atribuídos à expressão gestão, no âmbito da formação dos gestores escolares, é um forte indício, não apenas das várias formas de se realizar o trabalho de gestão, mas da falta de clareza acerca do que é definido como atividade de gestão quando nos referimos a instituições educativas, neste caso, especificamente à escola pública.

Com efeito, concluímos que há uma permanente generalização do uso da expressão, combinado com uma prática de incorporar discussões específicas e complexas do trabalho dos gestores escolares em uma disciplina que supostamente possa incorporar todos estes conteúdos formativos.

Identificamos que a disciplinas variam de nomenclatura conforme 0 recorte teórico que se estabelece como prioritário, preterindo-se a complexidade da profissionalização dos gestores, citando como exemplo: 


\section{As diversas nomenclaturas sobre Gestão}

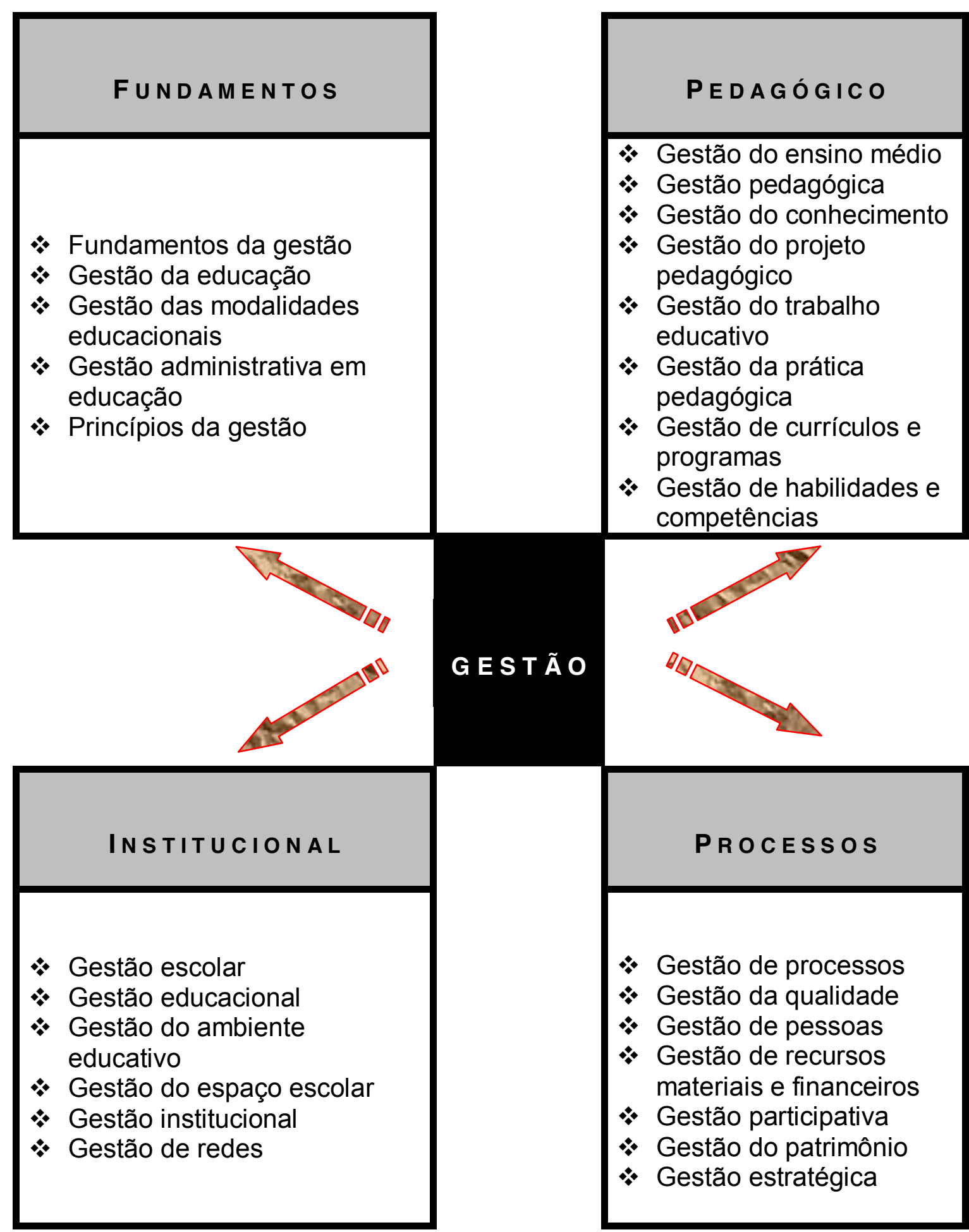


A partir destes elementos, podemos também identificar os diversos componentes que integram o trabalho do gestor escolar e, que portanto, o processo de profissionalização dos mesmos, ainda que na modalidade inicial, não pode se apresentar de maneira tão reducionista ou limitada a momentos exclusivos do curso.

Por outro lado, não se trata de disseminar disciplinas que aparentemente formariam o pedagogo em diferentes aspectos, mas sem refletirmos como os conteúdos e o currículo do curso se articulam para que os egressos possam lidar de forma mais competente e efetiva com os problemas a serem enfrentados, e que via de regra, não se constituem apenas por um aspecto do trabalho.

É fundamental que superemos a fragmentação de um pensamento de formação que, bem ao contrário, precisa ser sistêmico, evitando-se, inclusive, que tenhamos a manutenção e defesa de currículos que embora inchados, se tornam inócuos nesta perspectiva de um pedagogo, que atuando como gestor, tenha o campo pedagógico como centro do seu trabalho.

Na continuidade da análise da organização dos cursos de Pedagogia, identificamos outra tendência marcante: a aproximação dos currículos dos cursos com aspectos e elementos provenientes das instituições do mercado empresarial ou corporativo e, portanto, designados não pela lógica do sentido político pedagógico da escola, mas por uma lógica mais economicista.

Esta composição nos currículos corresponde também ao que é dito pelos profissionais que já atuam nos ofícios da gestão escolar: coordenadores pedagógicos, diretores de escola e supervisores de ensino afirmam o alto grau de vinculação destinado ao seu trabalho e o alcance de resultados e indicadores, a aplicação de recursos e implementos, a apropriação de práticas ligadas à gestão de processos, investimento nos discursos de liderança e gerenciamento, dentre outros aspectos que são marcantes em conteúdos 
definitivamente presentes em disciplinas que encontramos em vários cursos de Pedagogia que analisamos, como:

\begin{tabular}{|c|c|c|}
\hline \multicolumn{3}{|c|}{ D I SC I P L I N A S } \\
\hline $\begin{array}{l}\text { Chefia e liderança. } \\
\text { Gestão de recursos } \\
\text { humanos. } \\
\text { Marketing em } \\
\text { educação. } \\
\text { Pedagogia } \\
\text { empresarial. } \\
\text { Empreendedorismo. } \\
\text { sistemas escolares. }\end{array}$ & $\begin{array}{l}\text { Gestão de processos. } \\
\text { Gestão de pessoas. } \\
\text { Finanças em } \\
\text { educação. } \\
\text { Desenvolvimento de } \\
\text { pessoal e } \\
\text { gerenciamento. } \\
\text { Organização de } \\
\text { sistemas e métodos. }\end{array}$ & $\begin{array}{l}\text { Fundamentos e } \\
\text { práticas do } \\
\text { gerenciamento } \\
\text { escolar. } \\
\text { Gestão estratégica } \\
\text { em educação. } \\
\text { Pedagogia nas } \\
\text { instituições. } \\
\text { Empreendedorismo e } \\
\text { ensino. } \\
\text { Gestão } \\
\text { Organizacional }\end{array}$ \\
\hline
\end{tabular}

O que se coloca não é a negação de novos conhecimentos acerca da possibilidade de melhorar a organização do trabalho em instituições escolares, mas a infiltração de uma lógica própria do sistema econômico ${ }^{77}$ sobre as escolas, baseado principalmente na ideia de uma forma de gestão comprometida com a racionalização do trabalho dos profissionais da educação, isto é, a valorização de práticas meritocráticas, a ampliação de formas de controle e excessiva regulação do trabalho dos professores, o destaque para a

\footnotetext{
77 A aproximação do conceito de gestão escolar, ao de gerencialismo empresarial está fundamentada em princípios de eficiência, racionalização, qualificação, liderança e responsabilização dos professores, sob a ótica de que pela garantia destes elementos pode haver uma burocracia mais apropriada para controle da escola, com destaque nos seus resultados, a grande aproximação com as teorias da gestão estratégica. Os trabalhos desenvolvidos por Campos e Oliveira (2002), Fonseca e Toschi (2004) tratam com bastante propriedade esta forma de gestão inapropriada e distinta do que concebemos como gestão necessária para uma escola comprometida com a educação democrática e com qualidade social. Portanto, a simples alteração de nomenclatura não resolve a situação conflitante sobre a prioridade do campo pedagógico em todo trabalho relacionado à organização da escola.
} 
necessidade de avaliação do impacto da educação por indicadores estatísticos, a ênfase do discurso economicista para a explicação de fenômenos e situações educacionais, dentre outros pressupostos que vão orientando o que se espera dos gestores escolares e, conseqüentemente, da sua formação.

Com o distanciamento da reflexão acerca da identidade, da formação, da atuação prática, ou seja, da profissionalidade e dos desafios para os gestores escolares, ocorre o afastamento da discussão do sentido político da educação e do trabalho na construção de uma educação efetivamente democrática, e com qualidade socialmente para toda a população.

Esta evidência nos cursos de Pedagogia passa a atrair não pelo valor intelectual e crítico a ser desenvolvido pelos pedagogos, mas por uma aparente modernização do curso para atender a uma lógica emergente na sociedade, que inclusive aproxima o conceito de qualidade com o domínio de destrezas e práticas eficientes, ao invés da proposta de se fazer com a melhor qualidade possível, como dissemos, qualidade social que deve ser estabelecida pelo projeto pedagógico das escolas e por um claro projeto de educação.

Observamos também que há significativa presença de disciplinas relacionadas especificamente com determinados ofícios dos gestores escolares, situação analisada em 45 matrizes curriculares, o que representa cerca de $35 \%$ dos cursos.

Dessa forma, ao mesmo tempo em que os cursos passaram a comportar uma série de disciplinas derivadas de outros campos profissionais, permanecem disciplinas que podemos considerar como clássicas no campo da formação dos então especialistas de educação, e que portanto remontam aos períodos regulados legalmente pelo Parecer CFE 252/69, como apresentamos como exemplo: 
- Princípios de Métodos em Administração, Supervisão ou Orientação Educacional;

- Estatística em Educação;

- Princípios do trabalho em Administração e Supervisão Escolar;

- Inspeção Educacional e Escolar;

- Fundamentos da Administração, Coordenação e Supervisão;

- Estudos Brasileiros em administração escolar;

- Orientação Educacional;

Em se tratando da disciplina "Orientação Educacional", colhemos um dado bastante interessante: no caso do estado de São Paulo é praticamente uma exceção os cursos que ainda a oferecem, realidade esta que contrapõe aos cursos das regiões nordeste ou sul do país, nas quais a presença da disciplina ainda está diretamente ligada às atividades também relacionadas pelo coordenador pedagógico, entretanto com uma aproximação maior ao cotidiano e comportamento do aluno, e não necessariamente da formação do professor.

Destacamos também que o mais relevante não é a existência destas disciplinas nos currículos dos cursos, como se a presença dessas fosse aspecto único para se considerar os cursos extremamente conservadores, mas o fato de, em muitos cursos, estas serem o espaço essencial pelo qual se enfatiza a formação destes profissionais nos cursos de Pedagogia.

Por outro lado, em 23 cursos analisados encontramos propostas de apresentação dos conteúdos formativos para a gestão escolar numa perspectiva que denominaríamos como disciplinas integradoras, a citar: Contextos de Organização da escola e gestão, Gestão do trabalho pedagógico na escola, Gestão dos processos educativos, Cultura e Gestão da Escola.

Pela análise do conjunto das matrizes, observamos que os mesmos apresentam disciplinas mais pontuais ligadas aos ofícios propriamente e, ao mesmo tempo, as que citamos anteriormente, como uma alternativa para a articulação dos elementos do trabalho da escola, na ótica e responsabilidade 
de todos os profissionais que atuam em atividades de gestão, como uma forma de entender melhor o fenômeno educativo que é eminentemente complexo e diversificado, o que implica na compreensão do ser pedagogo em diferentes campos de atuação e ofícios.

Os sujeitos que participaram da pesquisa e que já atuam como gestores escolares também indicam a importância da prática da gestão contribuir para se entender melhor e dialogar mais sobre a escola, lançando-se um olhar mais investigativo, como afirma um dos supervisores de ensino:

\begin{abstract}
"Uma competência que acho fundamental para o trabalho de supervisor é fazer com que o conhecimento teórico dialogue com a realidade e produza um conhecimento novo que contribua para o desenvolvimento da educação dos alunos daquela escola. Explico: muitas vezes propomos ações que a escola não consegue realizar, pois são idealizadas demais e em desacordo com as condições reais da escola e dos alunos e da comunidade. Outra competência que acho importante é desenvolver junto à formas de organização de seu trabalho, de modo a possibilitar torná-la produtora de conhecimento. A escola precisa saber o que se produz de conhecimento na Universidade, precisa se conhecer (autoavaliação) e então produzir seu próprio conhecimento. Essa organização precisa ser apreendida e tornar-se rotina". (Supervisor de Ensino)
\end{abstract}

Na mesma perspectiva de investigação da escola, ainda que ocorra em apenas 7 cursos analisados, sendo 5 em instituições públicas, são propostos componentes nomeados como: Grupo de Pesquisa em Gestão Escolar, Seminário Integrado de Pesquisa em Orientação e Supervisão Educacional, Pesquisa Prática em Coordenação Pedagógica, Experiências e Pesquisa em Gestão Educacional, isto é, componentes do currículo que destacam a sensibilidade investigativa a ser desenvolvida pelo pedagogo e o papel pesquisador dos gestores escolares na escola.

Apesar de presentes num volume de cursos bastante tímido, estas atividades didático-metodológicas revelam a importância da permanente aproximação entre a prática e a ciência na profissionalidade dos sujeitos, e portanto, importante também para o desenvolvimento da postura científica 
durante a profissionalização, como inclusive foi destacado no depoimento anterior, como uma necessidade sentida na escola.

Finalmente, ao considerarmos o estágio supervisionado obrigatório nos cursos de Pedagogia, identificamos que $72 \%$ dos mesmos determinam que parte seja realizada em atividades de gestão escolar; entretanto, ficam os indícios de que geralmente o mesmo ocorre em práticas de observação apenas, sendo encontrados somente 9 cursos que propõem o desenvolvimento de Prática Profissional ou Residência Pedagógica em Gestão, modalidades de aproximação com a escola e com o ambiente educativo que superam a formalidade excessiva de estágios mais burocráticos, como apontam, inclusive os sujeitos que participaram da pesquisa, a exemplo de um Supervisor de Ensino:

\begin{abstract}
"Penso que a questão do estágio é outra vertente que necessita ser revista na formação docente. Há muitos estudos sobre essa temática. Alguns estudiosos no assunto defendem a ideia da formação docente deveria concretizar-se depois de alguns anos de prática, em continuidade aos estudos realizados na universidade. Os concluintes estariam, durante os primeiros anos de atuação, sob orientação e acompanhamentos de tutores ou de professores mais experientes". (Supervisor de Ensino)
\end{abstract}

Neste caso, não nos deteremos à proposta da concretização da formação após anos de prática, necessariamente, mas à provocação que há problemas na forma de estágio realizada pelos egressos dos cursos de Pedagogia, algo que desprestigia a possível mentoria de profissionais mais experientes.

Apontamos então, que os cursos ainda precisam superar a concepção exclusivamente teórica ou fragmentária do trabalho dos gestores na escola, e por analogia, a proposta que apresentam para sua formação no âmbito acadêmico.

Há uma incidência expressiva de cursos ainda baseados em proposta mais operacional, que contempla de forma fragmentada o que fazem os 
coordenadores, diretores, supervisores ou orientadores na escola. Logo, é fundamental que sejam valorizadas alternativas mais capazes de problematizar os contextos educativos, como alternativa para superar o fracionamento profissional, que também é reconhecido por aqueles que já realizam as atividades na escola.

\subsection{O que fazem os gestores escolares: encontros e desencontros com a formação inicial}

Como apresentamos anteriormente, um dos propósitos desta pesquisa é relacionar a articulação da formação inicial dos pedagogos que atuarão nos diferentes ofícios relacionados à gestão escolar, e o que estes profissionais, já em exercício, apontam como necessário e relevante para o seu trabalho, a partir do conjunto de práticas que realizam no seu cotidiano.

Para tanto, em continuidade à análise das matrizes curriculares dos cursos que realizamos, trataremos dos relatos de gestores escolares sobre sua formação inicial e a relação com sua prática profissional, com o objetivo de indicarmos as convergências e divergências existentes, e que podem contribuir para as conclusões sobre a organização do curso de Pedagogia, com vistas à formação dos gestores escolares.

Procede, mesmo que panoramicamente, situarmos o perfil profissional dos sujeitos que participaram desta pesquisa, com a finalidade de demonstrarmos que nos referimos a dados trazidos por profissionais que já se dedicam a atividades do magistério, e que procuramos colher representações vividas em diferentes ofícios e locais da experiência de trabalho, destacando como principais características que: 
- dos 42 participantes da pesquisa, apenas 02 professores coordenadores pedagógicos não são licenciados em Pedagogia ${ }^{78}$, sendo que dentre os 40, há 14 professores coordenadores pedagógicos e diretores de escola e 12 supervisores de ensino, todos da rede estadual de São Paulo, pelas razões que já antecipamos;

- em relação ao tempo de magistério e experiência em gestão escolar, os professores coordenadores têm predominantemente 15 anos de magistério, e entre 05 e 10 anos em atividades de gestão; já os diretores de escola contam 15 a 20 anos de magistério e até 10 anos em atividades de gestão escolar; e os supervisores de ensino apresentaram uma média de 23 anos de magistério, com cerca de 12 anos em atividades de gestão escolar;

- 08 participantes, dentre diretores de escola e professores coordenadores atuam em escolas exclusivas de Anos Iniciais do Ensino Fundamental, enquanto que 20 deles em escolas com Anos Iniciais do Ensino Fundamental e Ensino Médio. Já os supervisores de ensino atuam em escolas que atendem as diferentes etapas da educação básica.

Em princípio, foi perguntado aos professores coordenadores pedagógicos (14), diretores de escola (14) e supervisores de ensino (12), licenciados em Pedagogia, quais as atribuições que se colocam como mais

\footnotetext{
${ }^{78}$ No caso da rede estadual do Estado de São Paulo, a Resolução SE 88/07, alterada pelas Resoluções SE 53/10 e 40/12, não exige que os professores coordenadores pedagógicos sejam licenciados em Pedagogia, sendo aceitas quaisquer licenciaturas para prover a função. Esta medida está relacionada ao fato de se tratar de posto de trabalho preenchido como função e não cargo, e é marcado por uma série de inquietações sobre a atuação profissional, pois, embora não exija a formação, possui um perfil amplamente vinculado ao fazer pedagógico, o que explicita, no mínino, uma contradição.
} 
recorrentes em seu trabalho, a partir de um conjunto de possibilidades presentes no perfil para os gestores escolares na rede estadual de São Paulo $^{79}$, conforme as Resoluções SE 88/07 e 70/10. As respostas foram aferidas numa escala de relevância de 1 (menor) a 5 (maior).

No primeiro momento de investigação com os sujeitos participantes da pesquisa, a intenção foi a de encontrar elementos que indicassem a relação entre o que os gestores escolares apontam como principais características e demandas de sua profissionalidade e os conteúdos e experiências que trouxeram de sua formação em Pedagogia, ou ainda, as expectativas que vislumbram acerca da profissionalização inicial para que a atuação profissional se desenvolva de uma maneira mais competente. Assim, pudemos colher os seguintes indicadores de relevância e recorrência de suas atribuições:

\section{Atribuições/habilidades estabelecidas pela Resolução SE 88/07}

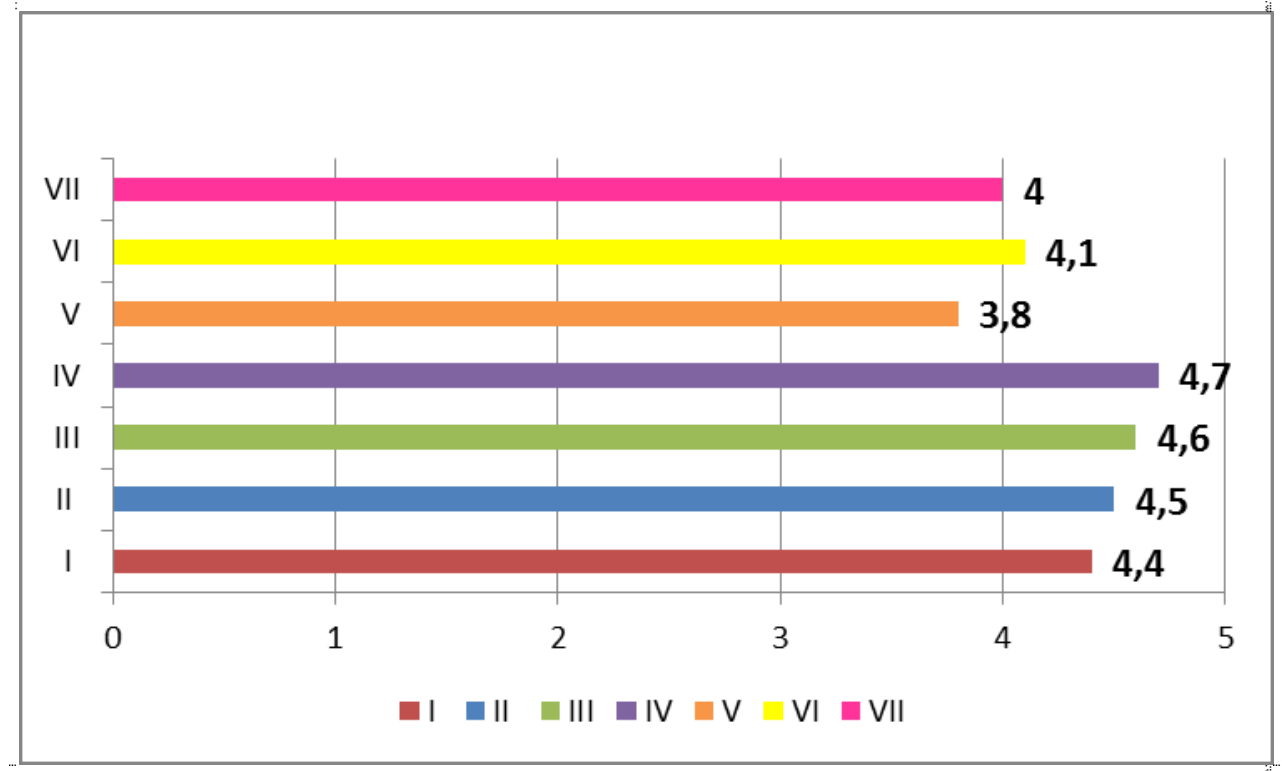

${ }^{79}$ A rede estadual de São Paulo foi abordada neste estudo, como referência de vínculo profissional dos sujeitos participantes em razão da abrangência de suas escolas por todo 0 estado, pela dimensão da população atendida pelo sistema paulista, assim como o número de gestores escolares pertencentes, e então por estes dados, considerá-la como uma tendência em relação aos gestores escolares, no que se refere à profissionalidade. 


\section{Legenda:}

I - acompanhar e avaliar o ensino e o processo de aprendizagem, bem como os resultados do desempenho dos alunos;

II - - atuar no sentido de tornar as ações de coordenação pedagógica num espaço coletivo de construção permanente da prática docente;

III - assumir o trabalho de formação continuada, a partir do diagnóstico de saberes dos professores, para garantir situações de estudo e de reflexão sobre a prática pedagógica, estimulando os professores a investirem em seu desenvolvimento profissional;

IV - assegurar a participação ativa de todos os professores do segmento/nível objeto da coordenação, garantindo a realização de um trabalho produtivo e integrador;

$\mathrm{V}$ - organizar e selecionar materiais adequados às diferentes situações de ensino e de aprendizagem;

$\mathrm{VI}$ - conhecer os recentes referenciais teóricos relativos aos processos de ensino e aprendizagem para orientar os professores;

VII - divulgar práticas inovadoras, incentivando o uso dos recursos tecnológicos disponíveis.

Os professores coordenadores apontaram que as atribuições ligadas ao processo de formação continuada dos professores e o fortalecimento da prática de trabalho coletivo na escola são aspectos mais relevantes em seu trabalho.

Entretanto, eles têm menos condições para a dedicação à exploração de materiais diferenciados para a prática pedagógica, além de condições insatisfatórias de trabalho para o desenvolvimento e exercício da criatividade, que é fundamental aos pedagogos em diferentes campos de atuação.

Interessante é o fato que tanto no caso dos professores coordenadores, como a seguir dos diretores e supervisores, há destaque para habilidades que contribuam para o reconhecimento da organização ambiente de trabalho e a relação com as políticas educacionais, a partir da possibilidade de se desenvolver um olhar mais investigativo acerca do contexto da escola, inclusive para melhores condições de intervenção. 


\section{Atribuições/habilidades estabelecidas pela Resolução SE 70/10}

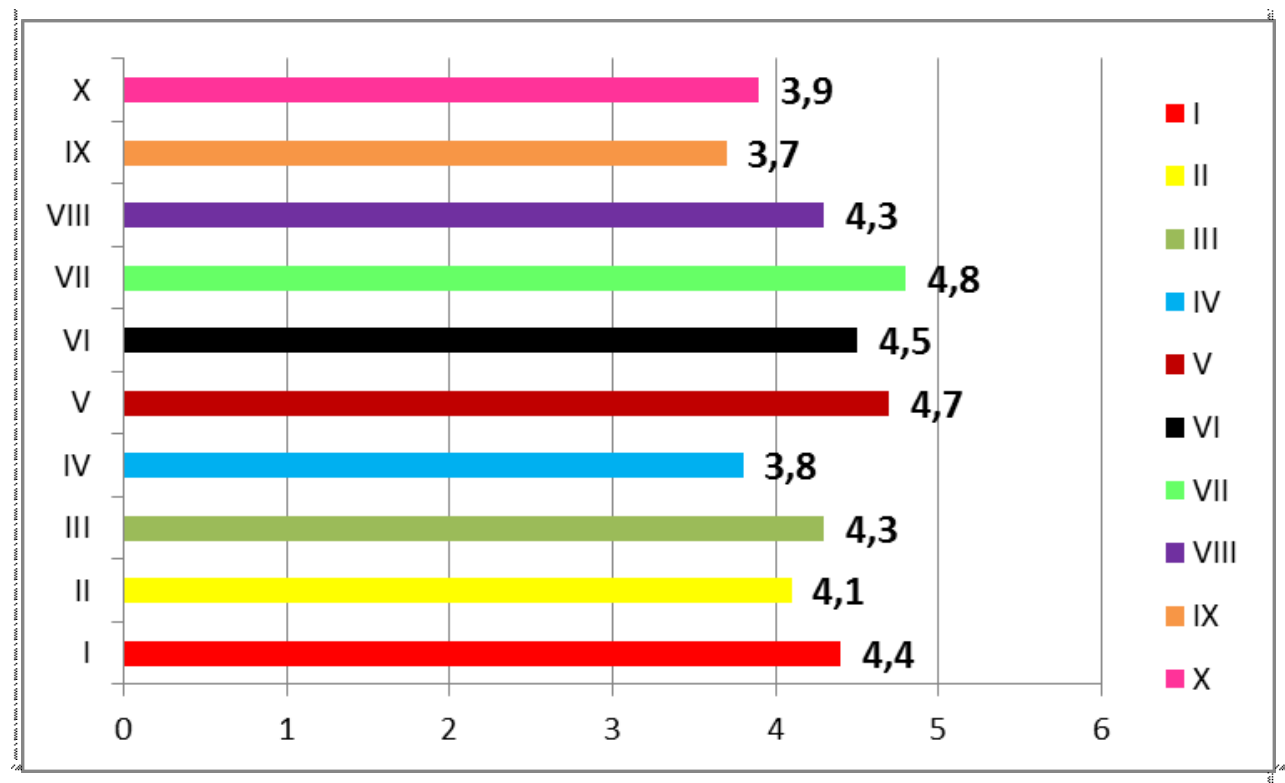

Legenda:

I - Compreender como o contexto social, político e econômico influencia a definição e a implementação das políticas educacionais.

II - Dominar e utilizar metodologias de direção/supervisão e tecnologias da informação como ferramentas para exercer as suas funções.

III - Compreender o papel da Diretoria de Ensino na organização da SEE-SP.

IV - Analisar e identificar os principais componentes de um Plano de Educação em nível nacional, estadual e regional.

V - Compreender os processos de implementação das políticas educacionais da SEE-SP e dos projetos a elas vinculados.

$\mathrm{VI}$ - Compreender a visão contemporânea de gestão escolar vinculada a resultados.

VII - Compreender os sistemas e processos de avaliações externas.

VIII - Demonstrar conhecimentos, princípios e métodos para exercer a supervisão e a direção como elementos catalisadores e difusores de inovações e boas práticas de ensino-aprendizagem.

IX - Diagnosticar as necessidades de formação continuada dos agentes educacionais.

$X$ - Compreender a importância da autoavaliação e do gerenciamento do autodesenvolvimento profissional.

Tanto quanto as questões de reconhecimento de políticas públicas educacionais, como da compreensão do contexto de trabalho dos diferentes profissionais da educação, nos dados apresentados pelos diretores e supervisores, identificamos a ênfase nas práticas que exigem gestão de resultados, análise de indicadores de avaliação interna e externa, articulação de políticas de sistema, conteúdos muito presente nos cursos de formação, conforme identificamos a partir de diferentes disciplinas vinculadas aos processos de avaliação. 
Destarte que assim como prescrito pelas resoluções que apresentam o perfil desejado dos gestores pelos sistemas de ensino, é apontado pelos participantes da pesquisa, que a valorização de atribuições e conhecimentos profissionais que apóiem o processo de construção do conhecimento na escola pública, a ampliação do trabalho coletivo, e o vínculo permanente entre escola e sistema educacional são atribuições mais exigidas.

Porém, há controvérsia quando os sujeitos indicam que as atribuições que mobilizam competências ligadas ao desenvolvimento e exercício da autonomia, à construção da identidade profissional, e principalmente à valorização do projeto pedagógico, desfrutam de menor prestígio durante a organização do seu trabalho.

Embora a contradição anteriormente apresentada não seja exatamente resultante apenas do desejo dos gestores, ou da falta de reconhecimento da importância de questões como autonomia, identidade e o projeto pedagógico das escolas, esta é uma situação que não raramente se constrói face às exigências de trabalho altamente burocráticas, que descrevemos inclusive nesta pesquisa.

Estas condições mais burocráticas, agregadas às atribuições tidas como prioritárias, e uma trajetória formativa que tenha dedicado menor valor às questões de intelectualidade e sentido político do trabalho educativo, provocam o afastamento de uma prática de gestão mais emancipatória e crítica, a qual já tratamos no capítulo II.

Uma de nossas preocupações ao identificar as atribuições mais recorrentes nas práticas dos gestores escolares, como apresentado nos dados anteriores, se voltou para a busca da relação entre o que realizam no seu trabalho, e os conhecimentos e capacidades que se destacam como fundamentais para o desenvolvimento das atividades profissionais. 
Em que pese nossa crítica ao pouco destaque que é dado ao desenvolvimento do projeto pedagógico da escola e as demandas que dele decorrem para o trabalho dos gestores, articulando assim às políticas públicas, delineando, ainda que de modo geral, as competências necessárias para este trabalho, levantamos quais os conhecimentos, capacidades e processos que os gestores escolares participantes da pesquisa elegem fundamentais terem para a realização do seu trabalho com melhor qualidade.

Para ilustrar o caso descrito, construímos um quadro que apresenta o que indicam como mais presentes no exercício de sua profissionalidade, para podemos analisar a partir dos depoimentos dos mesmos e as intersecções com as propostas dos cursos de Pedagogia, destacando:

\section{Principais Conteúdos de Trabalho (segundo os gestores)}

\begin{tabular}{|c|c|c|c|}
\hline Categorias & Conhecimentos & Capacidades & Processos \\
\hline $\begin{array}{l}\text { Professor } \\
\text { Coordenador } \\
\text { Pedagógico }\end{array}$ & $\begin{array}{l}\text { - fundamentos da prática } \\
\text { pedagógica; } \\
\text { - competência individual e } \\
\text { competência coletiva; } \\
\text { - possibilidades de formação } \\
\text { continuada. }\end{array}$ & $\begin{array}{l}\text { - articulação da equipe de } \\
\text { professores da escola; } \\
\text { - melhorar o relacionamento } \\
\text { interpessoal; } \\
\text { - oferecer oportunidades } \\
\text { diferenciadas de formação. }\end{array}$ & $\begin{array}{l}\text { - articulação de resultados ao } \\
\text { projeto pedagógico } \\
\text { - acompanhamento das salas de } \\
\text { aula e da prática pedagógica } \\
\text { - mediação de conflitos escolares; } \\
\text { - gerir os processos de formação. }\end{array}$ \\
\hline $\begin{array}{c}\text { Diretor de } \\
\text { Escola }\end{array}$ & $\begin{array}{l}\text { - diferentes tipos de avaliação } \\
\text { educacional; } \\
\text { - elementos do currículo } \\
\text { escolar; } \\
\text { - conhecimento metodológico } \\
\text { do trabalho pedagógico. }\end{array}$ & $\begin{array}{l}\text { - avaliar os indicadores de } \\
\text { avaliação; } \\
\text { - analisar a cultura da escola; } \\
\text { - valorizar a diversidade de } \\
\text { pessoas e conhecimentos na } \\
\text { escola. }\end{array}$ & $\begin{array}{l}\text { - implementação de políticas } \\
\text { públicas; } \\
\text { - intermediação de conflitos e } \\
\text { relações } \\
\text { - melhorar os processos } \\
\text { burocráticos da escola. }\end{array}$ \\
\hline $\begin{array}{c}\text { Supervisor de } \\
\text { Ensino }\end{array}$ & $\begin{array}{l}\text { - a prática da supervisão como } \\
\text { produtora de conhecimento; } \\
\text { - aplicação dos dispositivos } \\
\text { legais de forma } \\
\text { contextualizada; } \\
\text { - repertório pedagógico } \\
\text { pertinente ao contexto da } \\
\text { educação. }\end{array}$ & $\begin{array}{l}\text { - articular o conhecimento } \\
\text { teórico articular-se com a } \\
\text { realidade; } \\
\text { - mobilizar as equipes para a } \\
\text { inovação criativa; } \\
\text { - analisar os resultados e } \\
\text { indicadores; } \\
\text { - agir também como formador } \\
\text { de professores. }\end{array}$ & $\begin{array}{l}\text { - mediação entre o projeto das } \\
\text { escolas e as políticas públicas de } \\
\text { educação; } \\
\text { - construção de novos percursos de } \\
\text { trabalho para as escolas e a rede, } \\
\text { com as equipes locais; } \\
\text { - aprimoramento dos processos de } \\
\text { trabalho e de aprendizagem. }\end{array}$ \\
\hline
\end{tabular}


A partir do quadro construído, percebemos que os gestores apontam, em parte, a sincronia que as exigências do seu trabalho têm com muitos das capacidades previstas para serem desenvolvidas nos cursos de Pedagogia, conforme a Resolução CNE CP 01/06, como exemplo poderíamos citar: as questões de avaliação; a compreensão de currículo; a gestão das relações na escola; a cultura escolar e o ambiente educativo; o sentido dos dispositivos legais, além do destaque à formação continuada ${ }^{80}$.

Podemos também ponderar que se configura uma situação paradoxal, à medida que afirmam estarem mais afastados do apego aos clássicos ritos burocráticos que outrora marcavam os ofícios dos gestores, e conseqüentemente se aproximam de preocupações com sentido mais pedagógico, voltadas para as situações de aprendizagem dos alunos ou profissionais, o que em tese, corroboraria a perspectiva de gestão mais intelectual, autônoma e participativa que já defendemos.

Entretanto, esta mudança de perfil profissional não adere efetivamente a um fazer mais intelectual, crítico, colaborativo, que está diretamente ligado às concepções de educação que vão sendo construídas, que resulta das oportunidades nos cursos de Pedagogia, como já observamos, como pelas condições concretas de exercício do trabalho, que os afasta do profissionalismo desejado.

Apesar deste distanciamento entre a concepção de gestão que defendemos nesta pesquisa, e já apresentada, principalmente no capítulo II, e os pressupostos de formação apresentados pela maioria dos cursos, que apontam a busca à identidade da gestão escolar e educacional nos currículos

\footnotetext{
${ }^{80} \mathrm{O}$ destaque para a formação continuada previsto na norma do curso de Pedagogia, no perfil dos profissionais, e também apontado como conhecimento e capacidade fundamentais no trabalho cotidiano pelos gestores é algo a ser exaltado, se considerarmos o sentido da mesma para o desenvolvimento da escola e dos sistemas, entretanto, o descolamento da mesma do projeto da escola, da história de vida e profissional dos sujeitos, e das necessidades institucionais podem representar apenas uma nova roupagem para as remotas propostas de reciclagem ou treinamento, ou mais recentemente capacitação, que se distanciam do desenvolvimento profissional dos profissionais.
} 
dos cursos, é certo que já existe um movimento de mudança tanto nos fazeres profissionais, como na estrutura dos cursos, e esta combinação contribui para que os gestores escolares tragam dos cursos de Pedagogia diferentes conhecimentos, saberes e experiências para sua profissionalidade.

Ao tratarmos dos conhecimentos e saberes trazidos pelos egressos da formação inicial com os participantes, remontamos ao movimento histórico do curso que trouxemos nos capítulo I, ou seja, o afastamento de uma perspectiva altamente normativa, e a aproximação com pressupostos de um especialismo marcante na formação, que visaria fortalecer determinados aspectos do trabalho pedagógico da escola.

Recentemente, como trouxemos das matrizes dos cursos, aflora um processo de compreender a formação dos gestores pelos desafios, dilemas e contextos das escolas, a exemplo de algumas propostas presentes em disciplinas integradoras, o que demonstra que os profissionais não trazem dos cursos apenas conhecimentos prescricionais, mas também conhecimentos teóricos, além de algumas aproximações com o campo prático da profissionalidade, como revelam com maior ênfase em seus relatos:

\section{Principais conhecimentos trazidos da formação inicial em Pedagogia (segundo os gestores)}

\begin{tabular}{|c|l|}
\hline Ofícios & \multicolumn{1}{c|}{ Conteúdos } \\
\hline & - conteúdos relacionados às teorias do conhecimento, psicologia e \\
Professor & história da educação; \\
Coordenador & - referenciais teóricos acerca do trabalho pedagógico; \\
Pedagógico & e do currículo; \\
& - fundamentos da prática pedagógica e renovação do trabalho; \\
& - discussão da organização da escola em ciclos; \\
& - atuação como investigador das práticas pedagógicas. \\
\hline
\end{tabular}




\begin{tabular}{|c|l|}
\hline \multirow{2}{*}{ Diretor de } & - evolução do sistema educacional brasileiro e a legislação; \\
Escola & - trabalho no cotidiano escolar e tipos de gestão na escola; \\
& - organização do currículo e projetos na escola; \\
& - conhecimentos sobre história e filosofia da educação; \\
Supervisor & - práticas e governança das políticas educacionais. \\
\hline de Ensino & $\begin{array}{l}\text { - conhecimentos sobre as áreas de conhecimentos da educação: } \\
\text { filosofia, história e psicologia; }\end{array}$ \\
& $\begin{array}{l}\text { - movimento histórico da educação brasileira e a legislação; } \\
\text { contexto da escola; } \\
\text { - gestão do planejamento e currículo no sistema educacional; } \\
\text { - a importância e diferentes dimensões da avaliação na prática } \\
\text { educativa e escolar; } \\
\text { - a gestão da escola e os princípios participativos; } \\
\text { - diferentes formas de organização da legislação na educação. }\end{array}$ \\
\hline
\end{tabular}

Os apontamentos apresentados pelos gestores escolares acerca dos principais conteúdos que trouxeram de sua formação inicial, e que diante da profissionalidade têm se apresentado como mais relevantes demonstram que, de fato, ocorre um movimento de mudança nos cursos de Pedagogia, e tal movimento minimamente assinala que o modelo vigente, ou formas mais clássicas de organização dos cursos são insuficientes para as necessidades prementes nas escolas.

O movimento a que nos referimos contempla, ainda que timidamente, uma aproximação com as demandas e desafios que se apresentam no cotidiano da escola, e que, portanto, são fatos e processos desafiadores para os profissionais darem conta, de maneira que a escola esteja melhor organizada para a garantia da aprendizagem. Isto não representa o desligamento das questões legais ou de conhecimentos acerca de práticas normativas na escola, mas um distanciamento da visão de que estes aspectos são centrais no trabalho dos gestores escolares. 
Este processo de mudança nos conteúdos da formação dos gestores escolares também pode contribuir para o reconhecimento de que a legislação e a burocracia necessárias precisam estar a serviço da melhoria do trabalho na escola, das condições de trabalho e de aprendizagem dos atores do processo educacional, o que de certo, também implica na reflexão crítica acerca do que se faz como gestor e qual o sentido destes fazeres.

O empenho no sentido de encontrar a relevância dos saberes pedagógicos nos fazeres dos profissionais se coloca também como parte de um projeto de reconhecimento da Pedagogia como campo privilegiado de profissionalização dos gestores escolares, sob o risco de pairarem dúvidas acerca da importância de tais conhecimentos da ciência pedagógica para a gestão da escola, como um do professor coordenador pedagógico, participante da pesquisa, sugere que:

"O curso de Pedagogia, como está estruturado na maioria das faculdades e
universidades atualmente se mostra ineficaz para a formação prática de um
profissional da educação, uma vez que não aborda os temas e a realidade
pertinente do contexto educacional brasileiro. Desta forma, até o presente
momento não vejo onde minha prática poderia der melhorada. Gostaria de
ressaltar que o fato de minha área de formação não ser a Pedagogia, não me
impede de buscar teorias, estudos publicados sempre que alguma dúvida
ocorra pois a atuação de um bom profissional passa por sua formação teórica,
que infelizmente não é suprida pelos cursos de Pedagogia oferecidas pelo
mercado". (Professor Coordenador Pedagógico)

Todavia, assim como encontramos na análise das matrizes dos cursos, nos relatos dos participantes da pesquisa observa-se a carência na discussão de questões como o projeto pedagógico como definidor da cultura da escola, a construção da identidade dos gestores escolares enquanto sujeitos institucionais, e as possíveis contribuições de cada um dos ofícios de coordenação, direção, supervisão ou orientação, no tratamento de processos escolares comuns ou nos problemas a serem enfrentados.

Sem exageros, a fragilidade na discussão destes aspectos permite a persistência de um modelo de formação baseado no que é segmentadamente 
cada ofício do pedagogo não docente na escola, muito mais pelas suas diferenças, do que pelo que deve Ihes unir na atividade pedagógica: a ação e os saberes pedagógicos.

Este reconhecimento de que o fenômeno pedagógico é o ponto de vinculação dos diferentes ofícios existentes no campo da gestão escolar e educacional é uma forma não apenas de valorizar no que se deve o trabalho pedagógico, mas de reconhecer que é determinante que a formação precisa ser articulada com as vivências práticas na escola, combatendo a histórica cisão entre teórica e prática, tanto no plano do discurso como dos fazeres no campo da educação, o que implica em como são formados os gestores, como sugere um dos diretores de escola que participou da pesquisa:

\footnotetext{
"Apesar de ser articulada aos demais ofícios que o pedagogo desenvolve na escola, a identidade do curso fica comprometida quando não consegue formar adequadamente professores para o desenvolvimento de trabalho em sala de aula, articulando de forma competente a teoria e a prática e tampouco gestores capacitados para atuarem na organização e mobilização das diferentes dimensões que estão presentes na gestão da escola: pedagógica, resultados educacionais, pessoas, serviços e recursos". (Diretor de Escola)
}

Colhemos também dos gestores escolares uma série de elementos que balizam algumas possíveis evidências deste processo dinâmico e contraditório nos cursos de Pedagogia, que simultaneamente busca a aproximação da formação com temas mais contemporâneos do contexto de trabalho dos profissionais, mas que permanece, predominantemente, como a abordagem isolada de cada um dos ofícios, ou mesmo um tratamento aligeirado das tantas capacidades e conhecimentos que lhes são necessários para uma atuação mais competente.

Apresentaremos no próximo quadro a sistematização do que os 40 sujeitos participantes da pesquisa colocam como conteúdos tratados de maneira mais frágil ou mais aprofundada nos seus cursos de formação inicial em Pedagogia, e que contribui para identificarmos algumas das razões pelas quais ainda persiste uma grande dificuldade em se consolidar uma concepção 
de gestão fundamentada em princípios de autonomia, criticidade e intelectualidade, que rompa com o pragmatismo prescricional, que ora marcou os ofícios de gestão na educação brasileira:

Tratamento dos conteúdos na formação inicial, segundo os sujeitos

\begin{tabular}{|c|c|}
\hline Tratamento mais aprofundado & Tratamento mais superficial \\
\hline $\begin{array}{l}\text { - diferentes modalidades de legislação; } \\
\text { - conceitos de letramento e alfabetização; } \\
\text { - dificuldades para alfabetização; } \\
\text { - princípios da educação infantil; } \\
\text { - história, filosofia e psicologia da } \\
\text { educação; } \\
\text { - a profissão professor; } \\
\text { - conceitos de currículo na escola; } \\
\text { - diferentes aspectos da avaliação; } \\
\text { - as diferentes funções na escola e suas } \\
\text { atribuições; } \\
\text { - a diversificação da prática pedagógica } \\
\text { na escola (aspectos teóricos); } \\
\text { - a construção e o papel do projeto } \\
\text { político pedagógico na escola }\end{array}$ & $\begin{array}{l}\text { - diferentes alternativas metodológicas } \\
\text { para o ensino; } \\
\text { - práticas efetivas de formação } \\
\text { continuada na escola; } \\
\text { - os diferentes conflitos existentes na } \\
\text { escola; } \\
\text { - alternativas de trabalho interdisciplinar e } \\
\text { com o currículo escolar; } \\
\text { - a gestão de recursos na escola; } \\
\text { - o contato com "a vida" dos profissionais } \\
\text { na escola; } \\
\text { - a realização do estágio que sempre foi } \\
\text { muito teórico; } \\
\text { - experiências sobre o uso da tecnologia } \\
\text { e o tratamento das situações de inclusão } \\
\text { na escola; } \\
\text { - as diferentes situações e formas de } \\
\text { registro na escola. }\end{array}$ \\
\hline
\end{tabular}

Podemos inferir que os relatos apresentados pelos gestores escolares demonstram o que temos alertado sobre os riscos na formação inicial, provocando situações como o tratamento destacado dos ofícios ainda de maneira compartimentada, ou seja, o que cabe a cada um, o que o é cada um deles na estrutura dos sistemas de educação, e pouco destacando as possibilidades de articulação dos mesmos, com atribuições e competências distintas, sobre os diversos aspectos da cultura escolar. 
Note-se que, os aspectos mais integradores no trabalho dos gestores acabam sendo tratado de maneira mais frágil e superficial nos cursos, preteridos por conteúdos relacionados diretamente a procedimentos normativos, aos fundamentos teóricos da educação, ou aspectos conceituais do trabalho pedagógico, algo que acontece sem a possível e devida interlocução com o mundo real do trabalho da escola, espaço no qual se constitui a práxis, o que atende inclusive a perspectiva de trabalho dos próprios gestores, como afirma um dos participantes da pesquisa:

\begin{abstract}
"Acredito que os cursos de formação do pedagogo devem propiciar aos futuros profissionais conhecimentos que Ihes garantam "competência" mínima para poderem atuar juntos a diferentes situações-problema que surgem em sua práxis, para isso, sua formação, acredito eu, não deve ser restrita. Compreenda-se que ao defender essa idéia não coaduno com a precarização dos cursos e muito menos com as fragmentações, ao contrário, defendo um curso que contemple diversos campos do saber e que sua grade curricular propicie oportunidades de se vivenciar práticas investigativas mais aprofundadas, rompendo com a superficialidade que temos verificado em diversos cursos existentes na atualidade". (Supervisor de Ensino)
\end{abstract}

É fato, que na maioria dos cursos, temas emergentes como avaliação educacional, organização do currículo, formação dos diferentes profissionais da educação, ou situações relacionadas aos diversos focos da gestão são contemplados, entretanto, o que está em jogo é o tratamento atribuído a estes conteúdos nos cursos de Pedagogia, tanto no que se refere à forma, tempo ou conteúdos.

Reiteramos que os elementos dos cursos de Pedagogia que nos parecem conflituosos para a formação inicial dos gestores escolares, pela análise das matrizes curriculares dos cursos, considerando o movimento histórico do próprio curso e o conceito de gestão que estamos defendendo, mais enfaticamente no capítulo II desta pesquisa, compatibilizam nossos fundamentos teóricos com as percepções dos profissionais acerca do que é fundamental que os cursos proponham, de modo que sejam mais significativos para a profissionalidade dos sujeitos. 
Julgamos que a aproximação da base teórica, com os referenciais apresentados pelos gestores escolares já em exercício contribuirá para que possamos estruturar uma base epistemológica para o apontamento de algumas orientações para a organização de cursos, de maneira que a gestão não seja um campo tão preterido, como temos identificado.

Dito de outro modo, aparentemente, em muitos casos, a presença da formação para a gestão escolar aparece nos currículos apenas como um suposto "chamariz", como sugere um supervisor de ensino, o que deteriora ainda mais esta pretensa profissionalização:

\footnotetext{
"As licenciaturas em Pedagogia são, na sua grande maioria, realizadas em três anos ou em 18 meses, quando o profissional já possui outra licenciatura. Certamente, isso acontece em virtude de vários fatores. O mais aparente é o fato de as Faculdades competirem entre si para oferecê-lo no menor prazo possível, seja na forma de licenciatura ou de complementação (aproveitando horas de estudos já realizados), como "chamariz" aos candidatos, sem os quais não sobreviveriam. Parece-me que o Brasil, já há algum tempo, fez a opção por titulação quando o tema é formação profissional. Nesse sentido, as Faculdades estão atendendo a essa "necessidade" nacional". (Supervisor de Ensino)
}

Deste modo, constatamos que os sujeitos apontam a relevância dos cursos e não desprezam os fundamentos teóricos das áreas de conhecimento da Pedagogia, todavia destacam que é fundamental a relação com os contextos escolares nos quais se desenvolve a prática profissional e o projeto pedagógico das escolas que deve impulsionar seu desenvolvimento institucional. Assim, agrupamos os apontamentos feito pelos 40 professores coordenadores pedagógicos, diretores de escola e supervisores de ensino, em 3 categorias sobre o que trazem da sua formação, como segue: 


\section{Categorias e Conteúdos do Trabalho dos Gestores Escolares}

(segundo seus depoimentos)

Conceitual: avaliação da escola e planejamento; características do processo educativo e currículo; formas de liderança; burocracia mínima necessária; potencialidades e entraves escolares; o projeto pedagógico da escola; cultura da escola e suas implicações; formação continuada de profissionais, e políticas públicas em educação e sistema educacional.

Metodológico: organização de trabalho da equipe de gestão; distribuição dos tempos; espaços e recursos escolares; alternativas de formação da equipe; tratamento da avaliação externa, institucional e da aprendizagem; e visão sistêmica de organização do trabalho; orientações para articulação dos atores escolares.

Procedimental: análise de situações de aprendizagem; estudo e aplicação da legislação; atendimento da diversidade na escola; encaminhamento dos resultados escolares; planejamento de tarefas institucionais; e atuação investigativa sobre a escola.

Como já defendemos, a concepção de gestão do trabalho na escola pública, especialmente, é construída não apenas pela qualidade do trabalho realizado em cada ofício de gestor presente na instituição, mas sobretudo pela conexão construída entre os sujeitos, tendo como propósito acolher as prioridades semelhantes a partir de diferentes enfoques, perspectivas e instrumentos de atuação, convergindo para o desenvolvimento institucional pressuposto por um projeto colaborativo. 
$\mathrm{Na}$ análise das necessidades apontadas pelos gestores escolares, também detectamos que é refutada a especificidade fragmentária que fora então estabelecida pelo Parecer CFE 252/69, uma vez que os diferentes aspectos que constituem as categorias que organizamos coadunam para perspectivas de trabalho semelhantes, demonstrando também, como acreditamos, apoiados nas contribuições de Silva Jr. (2003), dentre outros, que o administrativo e o pedagógico precisam ser percebidos distintos, porém complementares na atuação do gestor.

Nesta mesma direção, Pinto (2011) destaca que o foco da atuação do pedagogo escolar, responsáveis pelas atividades de coordenação do trabalho na escola é o apoio no processo de desenvolvimento da aprendizagem de alunos, professores e outros sujeitos, ou seja, deve ter como prioridade a ação pedagógica:

O cerne do trabalho do pedagogo escolar é justamente a coordenação do trabalho pedagógico, e o trabalho pedagógico, por sua vez, é o núcleo das atividades escolares. Ele representa o conjunto de todas as práticas educativas que se desenvolvem dentro da escola. Envolve, portanto, as atividades docentes e discentes, assim como as atividades dos demais profissionais não docentes. Entretanto, a referência central do trabalho pedagógico são os processos de ensino e aprendizagem que acontecem na sala de aula. (PINTO, 2011, p. 151).

Destacamos que o conjunto de relatos dos profissionais que trouxemos, assim como os dados dos cursos que apresentamos no decorrer da pesquisa, avigora o pressuposto de que a formação inicial dos gestores precisa se organizar de tal modo que os diferentes ofícios sejam distintamente reconhecidos como meios para a apropriação de um saber comum, o saber pedagógico.

É nosso entendimento que justamente este saber pedagógico que deve ser colocado como a base do modo de fazer gestão na escola, pois caso contrário, permanecemos sob o risco de aceitarmos a continuidade do abismo entre o que se diz sobre os saberes pedagógicos e como se faz, acenando 
para a condição obsoleta da formação em Pedagogia, como aponta um Diretor de Escola:

\begin{abstract}
"As atividades de gestão escolar, não são restritas apenas à Pedagogia, é necessário sim, ter conhecimentos sobre práticas pedagógicas, sociologia, didática, etc. No entanto, gerir uma escola abrange também aspectos não somente pedagógicos, como administrativos. Ser diretor exige que sejamos pedagogos, educadores, administradores de empresas, que tenhamos conhecimentos sobre recursos humanos, etc. O gestor escolar necessita de conhecimentos específicos e globais para exercer sua função com dinamismo e competência. A formação em Pedagogia contribui para exercemos a função como Diretor de Escola, no entanto não é suficiente. Na prática, lidamos com situações que vão além do que é oferecido nos cursos de Pedagogia". (Diretor de Escola).
\end{abstract}

Os relatos apresentados pelos participantes da pesquisa sugerem, como temos apontado na defesa do conceito de gestão no qual acreditamos, que predomina a ênfase nas atividades diretamente relacionadas ao campo da administração escolar.

Deduzimos que por duas razões fundamentais, prevalece a ênfase na administração escolar: a mais remota, relacionada à presença mais perene da função de direção na educação brasileira; e a mais recente, pela aproximação do discurso educacional à lógica de mercado, que tem efeito perverso e deletério sobre os princípios fundamentais de uma educação socialmente democrática.

Formar estes profissionais no âmbito da Pedagogia, o que nos parece a alternativa mais adequada, é também uma forma de superarmos uma situação de compreensão de trabalho educativo, no qual os pedagogos, que atuam como professores, são vistos como responsáveis pela aprendizagem, pelos saberes, pela ação pedagógica, enquanto que os demais pedagogos são considerados responsáveis pela organização e funcionamento da escola, algo que denuncia um paradoxo no que diz respeito à complexidade dos fazeres escolares, como inclusive aponta um dos professores coordenadores que participou da pesquisa: 
"Vejo a formação em Pedagogia como a melhor opção, pois a questão pedagógica precisa ser repensada e trabalhada por todos os profissionais, o coordenador, o diretor, e o supervisor também precisam ter visão quanto a coordenação pedagógica, pois a escola é um ambiente dinâmico e só terá sucesso se toda a equipe gestora estiver pensando e repensando o pedagógico da escola, não dá para achar que o Coordenador Pedagógico dará conta sozinho, pois é uma questão ampla. O pedagógico é e deve ser o foco de toda equipe gestora, todos devem buscar soluções para os obstáculos do dia a dia na prática dentro do contexto de sala de aula, já que o aluno é o objetivo a ser atingido". (Professor Coordenador Pedagógico)

As evidências que apresentamos sobre a maneira que tem se dado a formação dos pedagogos para a gestão escolar, assim como a compatibilidade desta profissionalização inicial com o contexto de atuação destes profissionais, mais especificamente os desafios da escola, apontam para a urgência na reorientação dos cursos, que não contribuem satisfatoriamente para que estes profissionais lidem com tudo o que acontece na esfera da escola e no sistema.

\subsection{Quando a gestão escolar contribui para o desenvolvimento institucional}

O caminho que temos trilhado nesta pesquisa tem como objetivo apontar para a defesa de que não só é possível, mas necessário, que o trabalho dos gestores escolares seja organizado para fomentar possibilidades formativas mais significativas, autônomas e críticas, considerando, sobretudo o contexto da escola pública brasileira, e a importância da articulação das equipes escolares em favor do projeto pedagógico, sem o qual arriscamos estar lançados à deriva da descontinuidade de políticas educacionais, ou mesmo a situações externas de controle do trabalho da escola.

Por acreditar na compatibilidade entre o desenvolvimento profissional dos professores e o desenvolvimento institucional das escolas, entendemos que a formação dos pedagogos responsáveis pela gestão da escola é um dos 
fatores que implicam na mudança de organização do trabalho escolar, de modo que se reconheçam os limites e as possibilidades institucionais (Day, 2001), ao mesmo tempo em que os profissionais avancem da condição de principiantes a peritos $^{81}$ no trabalho.

Para nos aproximarmos de nossas considerações acerca das implicações do profissionalismo dos gestores escolares para o desenvolvimento institucional, ou seja, de que maneira seu modo de fazer pode contribuir para a organização de outra escola, enfatizamos que tais gestores precisam ser competentes na compreensão dos seus papéis e possibilidade de atuação em situações complexas, o que sugere a compreensão do sentido de seu ofício, a interpretação do ambiente no qual está situada sua prática, além da atribuição de significado às experiências de trabalho vivenciadas, um movimento que conceberíamos como construção da práxis.

Neste caso, não se trata de qualquer profissional, qualquer modo de agir, ou mesmo de qualquer repertório de atividades práticas, mas da consciência acerca da razão do pedagogo no âmbito da cultura da escola, o que confere maior responsabilidade aos conteúdos que trazem de sua formação inicial e que se alteram quando inseridos no cotidiano da escola pública, e portanto, nos faz questionar: de qual Pedagogia temos vindo?

Consideramos fundamental retomarmos que a escola sob a qual vislumbramos a ampliação de um trabalho mais qualitativo se assenta num campo existencial marcado permanentemente por situações práticas que precisam ser consideradas nos cursos de formação, como um dos componentes para que se possa lidar com as contingências. Entretanto, não se

\footnotetext{
${ }^{81}$ Embora já tenhamos explicitado anteriormente, julgamos pertinente alertar que a idéia de perito a qual nos referimos é tida como conseqüência da realização do trabalho com a melhor qualidade social, priorizando o desenvolvimento dos sujeitos e dos propósitos institucionais, e reconhecendo as diferentes dimensões dos profissionais que fazem parte do contexto escolar. Deste modo, o que pretendemos é deixar claro o nosso afastamento com a proposta de aquisição apenas de habilidades, ou a demonstração de atuação eficiente alcançada através de destrezas e condições simbólicas na desprofissionalização docente.
} 
pode enveredar para um praticismo insensato que desvalorize o saber pedagógico de natureza investigativa, que assegura a dimensão científica da Pedagogia.

O desenvolvimento institucional, em nossa análise, é uma das tarefas mais desafiadoras para os profissionais que atuarão em atividades de suporte pedagógico, conseqüentemente, apontamos que a busca da identidade tanto dos atores da escola, quanto da própria instituição na direção da legitimação do trabalho, e a construção de práticas e objetivos sintonizados na ação educativa escolar.

Neste caso, poderá haver uma trajetória pela qual a escola conseguirá: superar as formas perversas de controle sob o seu trabalho, enfrentar a centralização hierárquica de decisões e tomada de rumos, criar estratégias para lidar com as limitações do tempo, de forma que o processo de construção de um projeto mais emancipatório supere momentos isolados e esporádicos de autoria, autonomia e criatividade, como sugere (DAY, 2001).

Quando tratamos desta perspectiva de gestão escolar que contribui para o desenvolvimento institucional, estamos também nos referindo à superação de certa crise de identidade que ao mesmo tempo aproxima os gestores dos discursos e idéias dos professores em sala de aula, mas os afasta no modo de fazer ou assumir o trabalho pedagógico.

Este conflito nos parece inevitável em razão da mutação da própria escola e das práticas educativas, ou seja, implica em maneira de os profissionais se reconhecerem no ambiente escolar e demonstrarem que diferentes ofícios são "frentes" do trabalho na escola, mas que devem ter as mesmas finalidades; o que implica em considerar que se trata do diferente e não do oposto, no âmbito da profissionalidade.

A compreensão do ambiente, de si próprio, e dos demais sujeitos, é que engendra a construção interdependente entre as políticas educacionais 
favoráveis à melhoria da educação, do projeto pedagógico da escola, e do projeto de vida dos atores da escola, acenando para uma profissionalidade mais consistente e que os apóie na fuga do labirinto de palavras que tem marcado os discursos relacionados à uma gestão de qualidade ${ }^{82}$.

Todavia, um trabalho comprometido com a qualidade social exige interpretação menos ambígua possível do ser gestor na escola, admitindo que há conhecimentos e instrumentos mais específicos para cada ofício a ser praticado, mas que os saberes pedagógicos circunscrevem a todos eles. $\mathrm{Na}$ esteira desta posição Pinto (2011) defende que,

Por outro lado, os processos educativos escolares extrapolam, cada vez mais, a sala de aula, com atividades planejadas coletivamente fora da sala de aula ou mesmo fora da própria escola. Neste sentido, o trabalho do pedagogo direciona-se ao apoio pedagógico e organizacional para que essas atividades e esses eventos aconteçam satisfatoriamente, conforme seus objetivos educacionais. Essa perspectiva de atuação do pedagogo escolar em coordenar e dar apoio pedagógico e organizacional às atividades do corpo docente e discente exige da escola um projeto político pedagógico como instrumento que garanta desenvolver um trabalho coletivo voltado para os seus fins educacionais. (PINTO, 2011, p.139)

Na linha de defesa deste preceito de educação e gestão com qualidade social, indicamos que a melhoria institucional é vinculante ao fato de os profissionais e atores da educação olharem atentamente para a cultura escolar e para a cultura da escola, e a respeito delas reconstruírem novas representações, fomentando que a escola se organize para outros trabalhos.

82 O conceito de gestão da qualidade deriva da concepção de gestão estratégica das instituições, que justifica a racionalização de meios, a prestação de contas, a prática da responsabilização excessiva dos sujeitos, e a atribuição de imenso valor ao "desejo" profissional como determinantes para a melhoria do trabalho, ou a transformação da realidade. Assim, há um descolamento do contexto e das condições de trabalho sob os quais se busca esta qualidade do trabalho, e mais especificamente da aprendizagem, do ensino e da gestão da escola. 
Nesta abordagem sobre a complexidade do que é formar, e formar colaborativamente, temos muitos dilemas a serem enfrentados, como assinala Perrenoud (2003), formar é partir também da prática, é ajudar a construir competências, é impedir a desmedida prescrição e favorecer a "escola pensada", principalmente para que a escola edifique modelos de análise de seu próprio desenvolvimento.

De acordo com as discussões, o modo de fazer dos gestores escolares apela para o que encontramos já nos depoimentos dos próprios sujeitos desta pesquisa, ou seja, a aproximação com o caráter essencial do fazer pedagógico: a garantia da aprendizagem coletiva na escola. Nesta esteira, Luck (2009) também enfatiza que o papel fundamental do ensino e dos gestores é a aprendizagem, principalmente pela via do projeto pedagógico da escola:

O objetivo maior da comunidade educacional revela-se, portanto, o de se estabelecer uma comunidade de ensino efetivo, onde persevere, coletivamente, não somente o ideal de ensinar de acordo com o saber produzido socialmente, mas o de aprender, em acordo com os princípios de contínua renovação do conhecimento, criando-se um ambiente de contínuo desenvolvimento para alunos, professores, funcionários e é claro, os gestores. O conhecimento da realidade ganha novas perspectivas: a organização do projeto político-pedagógico da escola e o seu currículo; o papel da escola e o desempenho de seus profissionais, que devem renovar-se e melhorar sua qualidade continuamente, tendo o aluno como centro de toda a sua atuação.

(LUCK, 2009, p.16)

De certo, esta tarefa complexa germina mais virtuosamente a partir do pensamento complexo e divergente, que precisa ser fomentado inclusive na formação inicial nos cursos de Pedagogia, que os leva ao encontro dos fundamentos da gestão no campo escolar e educacional, provavelmente mais virtuosa se decorrer do pensamento divergente dos atores da escola.

Neste caso, estamos chamando de pensamento divergente, a reflexão consciente e crítica que vai além do pensamento criativo, o que assegura que a gestão fundamentada neste preceito e comprometida com o desenvolvimento institucional supera a integração de ofícios, mas impõe a atribuição de sentido a tudo que se faz nas práticas de organização do trabalho e da sistematização 
da construção de iniciativas de intervenção na história da própria instituição, com múltiplos olhares, mas que se vinculam pelos mesmos propósitos.

Substancialmente, aproximamos o conceito de desenvolvimento institucional e profissional à mudança do sentido do que se faz, e da sensibilidade em relação ao como se provoca tais mudanças necessárias, podendo contribuir para a construção de um processo de articulação dos sujeitos em torno de desejos e necessidades que se coloquem como fundamentais a todos, como demonstram Libâneo, Oliveira e Toschi (2005):

Uma visão sociocrítica propõe compreender dois aspectos interligados de um lado, a organização como uma construção social envolvendo a experiência subjetiva e cultural das pessoas; de outro, essa construção não como um processo livre e voluntário, mas midiatizado pela realidade sociocultural e política mais ampla, incluindo a influência de forças externas e internas marcadas por interesses de grupos sociais sempre contraditórios e, as vezes conflituosos. Tal visão busca relações solidárias formas participativas, mas também valoriza os elementos internos do processo organizacional - o planejamento, a organização, a gestão, a direção, a avaliação, as responsabilidades individuais dos membros da equipe e a ação organizacional coordenada e supervisionada, já que esta precisa atender a objetivos sociais e políticos muito claros, relativos e escolarização da população. (LIBÂNEO; OLIVEIRA; TOSCHI, 2005, p. 322)

No plano profissional, o desenvolvimento é tomado por nós como a transformação da atividade em função, da função em ofício, do ofício em profissão e, por conseguinte, esta profissão circunstanciada pelo devido reconhecimento.

Conseqüentemente, não tratamos de profissionais inundados de teorias ou instrumentos prescricionais que os instrumentalize para operar na escola, mas sim, de profissionais hábeis, que vislumbrem uma educação mais promissora, e se sintam capazes de contribuir para a reparação dos danos pretéritos, de uma escola excludente, parcialista, excessivamente burocrática e morosa. 
No caso do desenvolvimento institucional, o conceito é tomado como indicativo de quais mudanças podem ser firmadas como substanciais, apontando minimamente: a autonomia na tomada de decisão, os mecanismos de regulação do trabalho, o fortalecimento da formas de profissionalização dos sujeitos, a melhoria do tratamento das políticas educacionais, o aprimoramento das maneiras de colaboratividade das equipes, valorização da definição de objetivos e princípios, além do destaque da criatividade e responsabilidade coletiva.

Isto posto, investir em uma formação mais integrada à organização da escola e do sistema é uma provocação que implica profissionais que tenham competência para orientarem, e não conduzirem o percurso cotidiano das instituições, desempenhando diferentes tarefas que lá se colocam como imprescindíveis, que devem ser definidas pelo projeto pedagógico, o que encerra que a gestão da escola precisa estar à serviço do serviço da escola.

Pautarmo-nos em conceito de gestão que não coadune para o que explicitamos como desenvolvimento profissional, permanecendo numa forma de gestão pelo controle burocrático, coloca-nos o risco de estarmos violando o sentido do projeto pedagógico da escola e de uma educação realmente democrática, afastando a legitimidade possível no trabalho de suporte pedagógico, e degradando o sentido público que deve ter a escola, no sentido de contribuir para a construção de uma outra realidade social possível.

Uma formação profissional que se baseie apenas em instrumentos metodológicos e normativos, que tendem a atrair uma leitura reducionista acerca das responsabilidades dos gestores, colide com esta gestão voltada para a emancipação e a autonomia institucional.

Esta leitura sobre o funcionamento da escola é uma forma de indicar o rumo da instituição, como aponta Libâneo (2004), a partir do qual a escola poderá melhorar o seu trabalho, superando a aplicação da norma fria e 
intempestiva que deriva das formas de gestão baseadas em modelos altamente estruturados ou padronizações e uniformizantes.

Dito de outro modo, estamos assumindo que a formação dos gestores escolares que se vincule à possibilidade de contribuir para o desenvolvimento das instituições não permite que transplantemos modelos de gestão admitidos com relativo êxito para instituições de outras naturezas como, por exemplo, o sistema empresarial, como lamentavelmente já demonstramos por evidências e conclusões preliminares nesta pesquisa.

É fato que a escola e, por assim dizer, a educação é espaço e experiência da vida e da conjuntura social que possuem e comprovam vida própria, que consideramos singular e, portanto, exigem uma forma de fazer a gestão institucional também de maneira própria, identificando e construindo alternativas próprias de realizá-las.

Reconhecer esta natureza própria da escola e da educação também enfrenta as ambigüidades acerca da compreensão do que se espera dos gestores escolares, reveladas tanto nos cursos que proliferam as nomenclaturas do que concebem como gestão, que pouco impactam na produção de verdadeiros saberes, em favor do que vivem em seus contextos, inclusive enfrentando o processo de mercantilização da educação que tem marcado o cenário brasileiro nas últimas décadas.

Logo, quando destacamos que os gestores precisam ter elementos que os apóiem numa atuação no sentido do fortalecimento da qualidade, nos referimos à qualidade social para o desenvolvimento daquele organismo, considerando o compromisso e condições de: valorizar as potencialidades; otimizar os recursos; promover a presença social e comunitária; assegurar a educação cidadã; reconhecer as experiências dos sujeitos; interpretar os contextos de inserção; identificar as possibilidades de melhoria do que se faz e se alcança, e relacionar a gestão à educação 
democrática, destacando que sem a prioridade na última os gestores podem tornar-se apenas reguladores.

Embora já tenhamos sido exaustivos nesta defesa, enfatizamos que apoiar o trabalho pedagógico na perspectiva do desenvolvimento institucional promove também a superação da condição contemporânea da escola, para que se possa garantir melhores condições de aprendizagem aos alunos, professores e demais profissionais da educação, e portanto, tem a ver com a realidade e condições de trabalho as quais estão à disposição dos profissionais.

Assim, em nosso entendimento, não se pode deixar de considerar as diferentes dimensões de concretização do desenvolvimento institucional, contemplando:

Aspectos para o Desenvolvimento Institucional

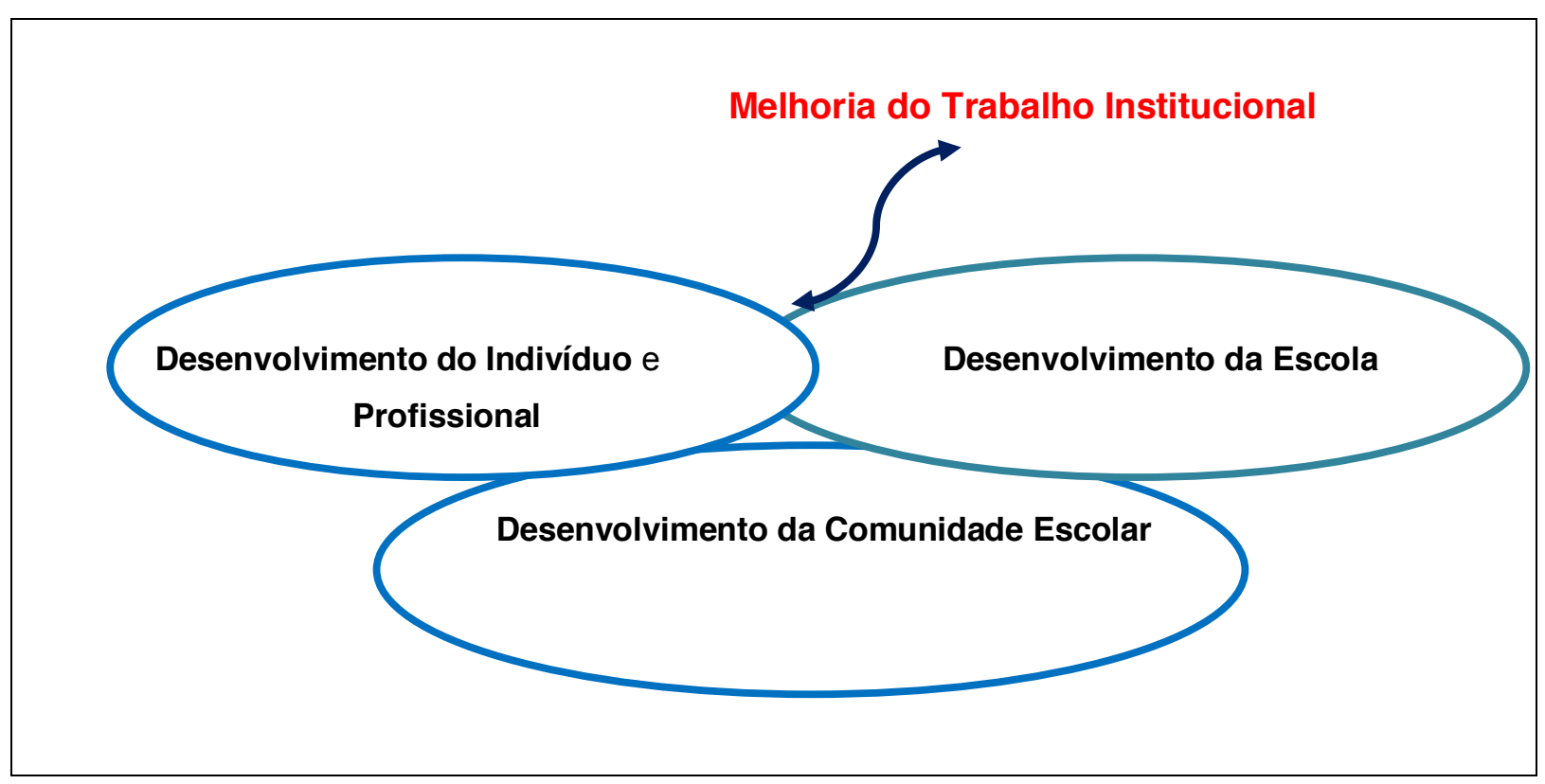

Os relatos apresentados pelos gestores legitimam também o quadro elaborado por Thurler (2001), que se refere aos aspectos relevantes na organização do trabalho na escola e que portanto, do ponto de vista da profissionalização dos gestores escolares, precisam ser contemplados nos conteúdos formativos, nas experiências propostas, nas diferentes formas de 
atividades que farão parte dos currículos dos cursos, de maneira que estes elementos sejam pistas para o trabalho a ser efetivamente consolidado na esfera na escola, que apresenta diversos aspectos:

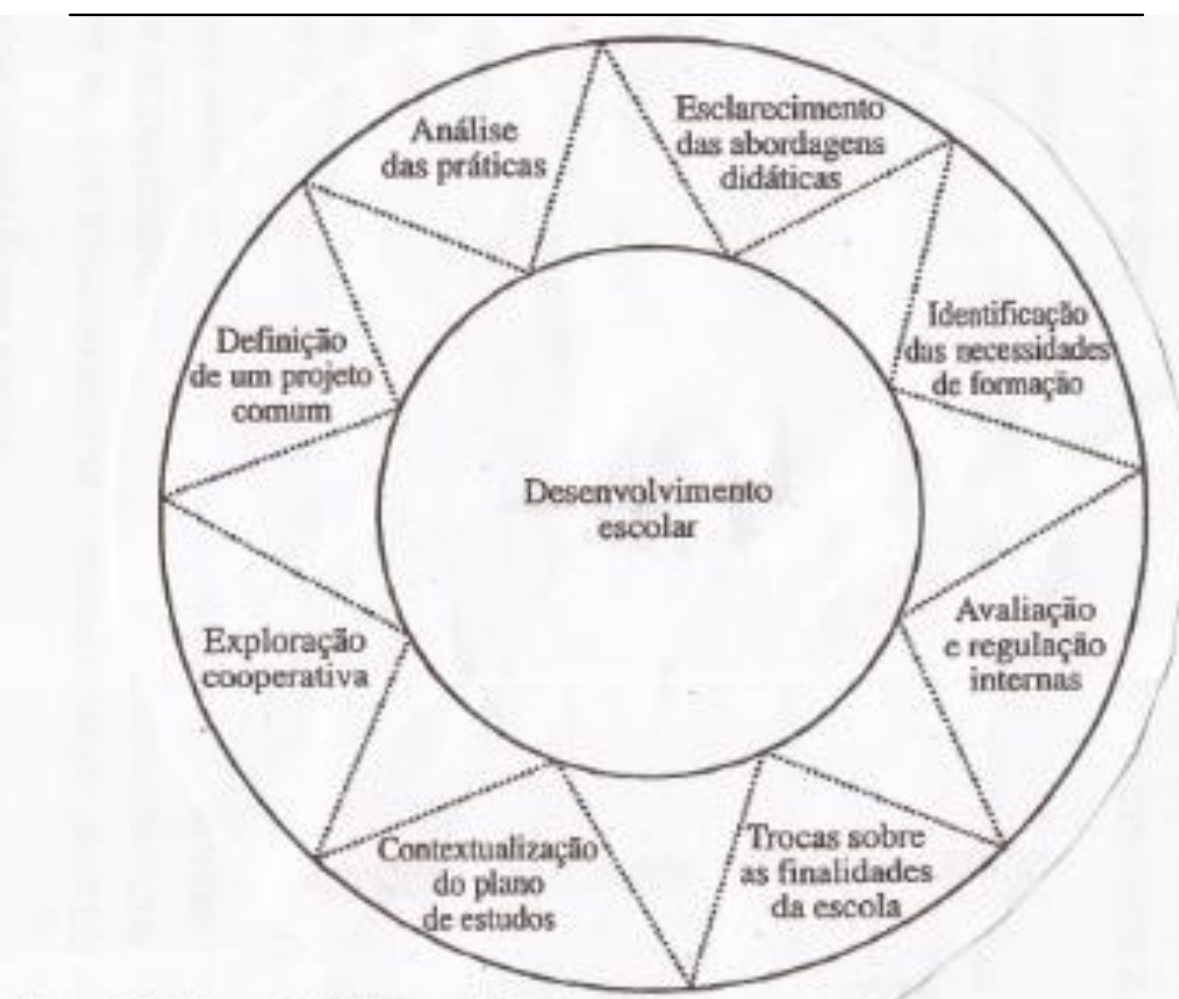

Figura 6.3 - A espiral do desenvolvimento escolar.

Mas os cursos de Pedagogia que formam os pedagogos para a atuação docente e também para serem gestores escolares demonstram tratarem esta demanda de desenvolvimento institucional e profissional com a propriedade devida? Como os cursos têm contemplado estas questões que fazem parte do processo de desenvolvimento institucional? De que forma as necessidades nas práticas de gestão têm sido previstas e incorporadas aos cursos de formação?

Diante do cenário que viemos apresentando, os cursos de Pedagogia, em especial no que se refere à profissionalização dos gestores escolares, precisam superar o modelo mais prescritivo que baseia na transferência de modos de fazer mais padronizados, para profissionais que atuarão em contextos cada vez mais complexos e por isso, clamam que os profissionais 
tenham postura, saberes e atitude investigativa ${ }^{83}$, que se contraponham às idéias que postulam as habilitações complementares, ou algum tipo de fracionamento dos cursos de formação.

Preliminarmente, defendemos que há imperativo na compatibilidade entre a formação e as necessidades de trabalho dos profissionais, como alternativa viável para que seja dado apoio aos gestores escolares no desenvolvimento das instituições escolares e de seus profissionais, de sorte que sejam capazes e competentes para a tomada de decisão e a construção das trajetórias institucionais, valendo-se de suas capacidades cognitivas, culturais, humanas e laborais.

Pela complexidade da profissionalidade dos pedagogos na escola, sustentamos que a formação dos gestores, assim como sua atuação precisam ser circunstanciada, o que não notamos na maioria das matrizes curriculares dos cursos de Pedagogia que compuseram esta pesquisa, ou seja, fica exposta uma expressiva fragilidade entre o modo de pensar dos profissionais, suas experiências e de suas demandas práticas, e as oportunidades que tem feito parte dos cursos responsáveis pela formação inicial dos mesmos.

É colocado, então, um grande desafio: indicações acerca da organização dos cursos de Pedagogia para que sejam elaboradas novas alternativas formativas no âmbito do projeto dos cursos, e mesmo no que se refere às prerrogativas legais disciplinadoras do curso, de modo que haja uma ampliação do sentido e do significado entre a profissionalização dos gestores

\footnotetext{
${ }^{83}$ Com muita propriedade, Christopher Day (2001), em sua obra Desenvolvimento Profissional de Professores: os desafios da aprendizagem permanente, apresenta o que considera como principais desafios para que a profissionalidade e profissionalização dos docentes se assente em bases mais investigativa, o que acreditamos também pertinência em relação à profissionalidade dos gestores escolares, ainda que mais especialista em determinado ofício. Nesta obra o pesquisador aponta como desafios principais: 1. As limitações de aprender sozinho; 2 . A capacidade de refletir; 3 . Atitude como profissional técnico ou prático reflexivo; 4. Postura confortável ou em confrontação; 5. Envolvimento nas possibilidades de mudança; 6. Exploração do continuum; 7. O aproveitamento do tempo; 8. Apoio crítico ao trabalho; 9. Dar voz aos professores e profissionais; e 10. Construção de culturas de aprendizagens profissionais.
} 
escolares, a profissionalidade consolidada no cotidiano real da escola, e o profissionalismo necessário para o alcance de uma educação de qualidade melhor para todos os cidadãos, fato este que, provavelmente, seja decorrente do desenvolvimento institucional da escola e do desenvolvimento profissional dos professores, que é uma tarefa eminentemente colaborativa, e que não se limita aos muros da escola. 


\section{CONSIDERAÇÕS FINAIS}

Neste momento de balanço dos estudos, evidências e análises realizadas durante esta pesquisa intencionamos sistematizar algumas das considerações que julgamos mais relevantes, em relação à formação dos gestores escolares no âmbito do curso de Pedagogia, de modo que sejam apontados os aspectos mais relevantes, além de algumas pistas que demonstram nossa contribuição para a tomada de rumo em relação à profissionalização, profissionalidade e alcance do profissionalismo destes atores do processo educacional.

Com este objetivo, organizamos as considerações a serem feitas em dois grandes blocos que demonstram aspectos fundamentais da pesquisa. Se fôssemos dizer de outra maneira, nos dedicamos a trazer as convergências e divergências entre o que existe e o que se apresenta como necessário para os pedagogos que atuarão em ofícios de gestão, assumindo compromisso de garantia de qualidade para todos que deve legitimar a escola pública.

Em um primeiro bloco, apontamos as principais evidências encontradas, tanto no que se referem às transformações em movimento, como as relações estabelecidas entre as propostas de formação dos gestores na Pedagogia, e como os profissionais de suporte pedagógico organizam seu trabalho.

No segundo bloco, destacamos os grandes desafios que ficaram demonstrados durante a pesquisa, e defendemos algumas alternativas que, a partir das análises realizadas, se colocam como caminhos possíveis para a reorientação do processo de formação inicial dos gestores escolares.

A organização destes dois blocos de considerações tem a finalidade de demonstrar que a presente pesquisa não somente alcançou os objetivos propostos inicialmente, relacionados à formação dos gestores escolares no curso de Pedagogia, mas avançou no sentido de propor caminhos possíveis para a melhoria deste processo que tem sido marcado pela deterioração dos 
diferentes campos de atuação supostamente incorporados para formação na Pedagogia, seja para a docência, a pesquisa, ou gestão escolar, que foi nosso foco de pesquisa.

\subsection{Encontros e desencontros entre a formação e as necessidades anunciadas}

Com os vários instrumentos dos quais nos valemos nesta pesquisa, e considerando a base teórica que nos apoiamos para defender o que entendemos como gestão e gestores escolares, assim como seu sentido e papel nas escolas pública, apontamos que ainda permanece a ruptura entre a formação dos pedagogos, no que se refere ao campo dos ofícios da gestão nos cursos de Pedagogia, e os que se coloca como fundamental nas atividades concretas que os profissionais realizam no plano da prática.

A cisão, a que nos referimos, não se afigura apenas no plano das teorias apresentadas, mas também nas diferentes modalidades de atividades que são propostas no decorrer da formação inicial, que aparentemente ainda os aproximam de forma muito frágil do contexto efetivo de atuação, e é justamente esta ruptura que deflagra a perversa atuação de instituições e órgãos controladores do sistema em manter a precarização da formação dos profissionais do magistério.

Fica ainda muito marcante uma formação inicial baseada em preceitos excessivamente fundamentalistas, que oferece um vasto repertório de conhecimentos teóricos e procedimentais, mas que pouco se aproxima da articulação da construção profissional de gestores que deverão atuar no sentido de olhar para outras formas possíveis de organização e desenvolvimento da instituição escolar, reafirmando uma lógica de responsabilização dos profissionais da escola pública pelos indesejáveis resultados que são intencionalmente divulgados, e que implicam uma forma de desvalorização do papel de uma essencialmente pública na sociedade brasileira. Este fato também tem justificado inúmeras contratações de 
instituições privadas para trazerem "novas" formas de trabalho para os atores da escola, ou sucessivas reformas que se propõem a invalidar a potencialidade da escola pública como espaço formativo.

Tornou-se explícito nesta pesquisa que a formação dos gestores escolares no âmbito da Pedagogia replica a situação de complexidade e de busca de modos de fazer mais vinculados às necessidades pontuais, como acontece nestes cursos, afastando-se de um projeto educativo que se comprometa enfaticamente com uma educação mais democrática.

Isto retrata simultaneamente o conflito entre uma identidade não definida e ao mesmo tempo, de tentativas de construção, seja pelas diversas lógicas orientadoras dos cursos de Pedagogia em todo o Brasil, seja pelas diferentes demandas e modos de fazer dos profissionais no sentido de valorizar o espaço escolar, como lugar da profissão, como trouxemos nos relatos.

Consequentemente, o reforço desta idéia de suposta incapacidade dos profissionais da escola pública em lidar com seus desafios e problemas contribui para a ampliação de projetos de formação de profissionais da educação que cada vez mais são assumidos pela iniciativa privada, expropriando a escola de sua criatividade pedagógica, como já indicamos.

Embora ainda exista ênfase em conteúdos sobre o "como fazer" nos cursos e diversidade de características que apresentam, esses demonstram também a pluralidade de representações, que pode intensificar o pensar a própria identidade do pedagogo como gestor.

Percebemos claramente a urgência de que os cursos definam mais claramente qual o conceito de gestão que tem orientado seu currículo quanto à formação do gestor, ou seja, superar a contradição de enunciados que sugerem uma concepção mais orgânica da escola pública e do trabalho essencialmente pedagógico em oposição a uma situação que denuncia um tratamento curricular operacional e funcionalista. Um discurso anunciado pelos 
títulos das disciplinas formadoras que não se sustenta no currículo dos cursos, e provavelmente em seu projeto pedagógico. Ou seja, que compromisso público de formação temos assumido diante dos atuais cursos de Pedagogia?

Apesar de a Resolução CNE CP 01/06 ter tornado extintas as habilitações no curso de Pedagogia, mas mantendo um conjunto de capacidades e habilidades a serem desenvolvidas pelos egressos do curso, dentre as quais aquelas relacionadas à gestão, ainda persiste um relativo especifismo nas situações de formação propostas pelos cursos, o que implica na continuidade de uma visão parcial da escola, como se esta se organizasse por segmentos, desconsiderando a notoriedade pedagógica que deve integrar todos os ofícios. Nos deparamos assim com um indicativo bastante claro: é impossível que os cursos de Pedagogia, do modo que tem sido organizados, contribuam efetivamente para o que teórica e legalmente se propõem a formar.

Este contexto se reflete no depoimento dos gestores, quando fazem referência à sua formação que predominantemente destacou conteúdos relacionados, por exemplo, à administração escolar (legislação e normas; e gestão de conflitos), ou à coordenação pedagógica, mais acentuada em conteúdos derivados da organização do tempo ou da prática pedagógica. 0 efeito de pulverização do currículo nos cursos de Pedagogia impacta na própria forma de atuação dos gestores escolares, que demonstram imensa dificuldade em definir o sentido pleno de seu trabalho numa escola pública que efetivamente assuma esse compromisso político de emancipação e autonomia.

O fato de persistir este especifismo na formação demonstra a ambivalência de cursos que sugerem a extinção de habilitações, mas tratam os ofícios de maneira um tanto quanto distinta, quase dissociada, o que provoca efeito deletério sobre a razão do pedagogo atuar na escola, em diferentes campos de trabalho, que é a aprendizagem colaborativa e o desenvolvimento institucional. 
Destacamos também que já encontramos relativa superficialidade no tratamento do projeto pedagógico das instituições na formação inicial dos gestores escolares, e não raramente figura apenas como disciplina no currículo, mas não como elemento integrador das práticas de gestão.

Podemos alertar que tal situação também se repete no cotidiano de trabalho dos gestores escolares quando mesmo reconhecendo a importância do projeto pedagógico da escola, dedicam maior parte de seu tempo a outras demandas, inclusive alheias os objetivos prioritários da unidade escolar. Eis que vai ficando mais perceptível a visão obtusa que tem sido proliferada também pelos cursos de Pedagogia, que muitas vezes incorporam o discurso corrente nos sistemas e redes educacionais, subtraindo a importância da profunda reflexão crítica sobre a formação proposta e a concepção de educação adotada.

Não bastasse o desvirtuamento da razão do trabalho dos gestores na escola e, por conseguinte da importância de que sua formação inicial se dedique à compreensão da cultura escolar e da cultura da escola, um dos efeitos perversos da situação que consideramos anteriormente é o reforço de que a boa gestão é aquela que se vale de procedimentos, ritos e instrumentos de forma mais eficiente e racional, interpretação que afronta a perspectiva de organização do trabalho para a autonomia, crítica e autoria escolar, atributos necessários a uma instituição em desenvolvimento.

Em que pese as virtudes das Diretrizes Curriculares para o curso de Pedagogia, no que se refere ao seu reconhecimento como lócus privilegiado para a formação do pedagogo destinado a diferentes campos de atuação, a disposição genérica das horas destinadas a todas as atividades do curso provoca o tratamento comprimido de aspectos como a gestão ou a atuação do pedagogo em outros campos de trabalho, que não a docência, que é tido pelo dispositivo legal como base da Pedagogia, embora discordemos, em parte, ao julgarmos o saber pedagógico como fundamento. 
Com efeito, as Diretrizes Curriculares para o Curso de Pedagogia que poderiam aquilatar o sentido do trabalho do pedagogo na educação, e portanto, e conseqüentemente tratar com a mesmo critério e valor a formação ocorrida neste curso, em muito consagrou a deterioração deste processo, prescrevendo uma formação pulverizada, comprimida e invadida indiscriminadamente por diferentes áreas e conhecimentos, preterindo-se o que efetivamente compromisso político com o "pedagógico".

A formação para a gestão, no curso de Pedagogia, acaba por receber um tratamento de complemento, semelhante ao que era a habilitação (o a mais), tendo, entretanto um espaço periférico no curso (o a menos), e que pouco se articula com o fazer docente, ou com as outras possibilidades ação pedagógica em outros espaços, muito pela previsão de atividades de modalidades diversas e importantes, num curso que se tornou "curto" para tantos conteúdos formativos, numa conotação de gestão como fim, e não meio, para o desenvolvimento de todo o pensamento pedagógico na escola. Com efeito, apontamos que o "lugar" da formação dos gestores no curso é contido e precarizado, assim como dos demais focos formativos do curso, que se avolumam do ponto de vista de disciplinas e atividades.

Estamos diante da intensa diversificação do conceito de gestão expresso pelo conjunto de componentes do currículo dos cursos, e que aponta o reconhecimento da pluralidade da atividade, contudo na maioria dos casos, as disciplinas aparecem em momentos pontuais do curso, ou com viés excessivamente teórico das atividades realizadas propriamente por coordenadores, diretores, orientadores ou supervisores.

Reitera-se, por conseguinte, a permanência de um especifismo ou de pseudo habilitações, mesmo que já extintas pelo ato normativo do curso, ou uma forma de tratamento da gestão assentada em formas padronizadas de construir a organização da escola. Transitamos, pois, do especifismo da formação para um generalismo da compreensão dos ofícios, ambos muito alarmantes. 


\subsection{Dos obstáculos encontrados e alternativas apontadas}

Adiante apresentaremos algumas proposituras defendidas para a mudança do rumo da formação dos gestores escolares nos cursos de Pedagogia, diante dos próprios desafios apresentados pelo contexto de trabalho, e pela possibilidade de desenvolvimento institucional das escolas.

Defendermos ser imprescindível a ampliação da discussão e uma nova definição acerca de qual o lugar da formação em gestão nos cursos de Pedagogia, ou seja, como pode ser dada um resposta mais eficaz a tantas necessidades de atuação do pedagogo neste campo, como articulá-la com o fazer docente, e sobretudo, enfrentando uma lógica de mercantilização que se coloca muito marcantemente nos currículos dos cursos, preterindo o sentido político pedagógico destes ofícios.

É determinante que os currículos dos cursos de Pedagogia sejam reestruturados no sentido de apontarem qual concepção está norteando os conteúdos, atividades, experiências e saberes sobre a gestão presente no trabalho pedagógico, demonstrando que as necessidades reais da escola se colocam no plano de uma gestão mais crítica e intelectual, que não corrobora ao entendimento funcionalista, instrumentalista e operacional da escola. Esta mudança de perspectiva formativa implica romper com uma lógica mercantilista que tem determinado a estrutura e organização dos cursos, desconsiderando o sentido político e intelectual que deve ter a formação no contexto educativo brasileiro.

Também concluímos que a formação dos gestores, tal qual sua atuação tem um compromisso essencial com a qualidade na educação, entretanto precisamos lidar com o conceito de qualidade que tem sido contemplado nos cursos, muito mais próximo de indicadores e desempenho do que de mudança, transformação e compromisso com a uma educação com qualidade socialmente mais democrática, o que exige uma formação mais investigativa. 
A inquietação que movimentava o ambiente acadêmico das décadas de 1960 e 1970 sobre a organização e função do curso de Pedagogia, posteriormente na década de 1980 , eclode na instituição escolar a partir de 1990 pela face da desprofissionalização generalizada da carreira do magistério ${ }^{84}$, que remete à reflexão relativa a que gestores são estes nas escolas? De qual Pedagogia tem vindo? Que mudanças são indicadas como necessárias em relação ao olhar para a escola?

$\mathrm{Na}$ intenção de apresentar alguma alternativa mais sistematizada para estas perguntas, acreditamos na efetividade da mudança de organização na formação dos gestores, provocação acerca do modo de pensarem sua profissionalidade, e também de foco na sua atuação profissional, avançando de uma referência convencional, que se volta, ainda de maneira fragmentada, para as políticas públicas:

\footnotetext{
${ }^{84}$ É salutar deixarmos registrado, que mesmo ainda em tramitação, os Projetos de Lei Federal 1287/11 e 1377/11, que Institui os Princípios e Diretrizes dos Planos de Carreira da Educação Básica para os sistemas educacionais brasileiros, e que por tal natureza, tem sido objeto de manifestação e mobilização da CNTE - Confederação Nacional dos Trabalhadores da Educação, além de outros sindicados e entidades de classe, e movimentos organizados do magistério, propõem dentre outras questões tão significativas quanto, a observância da formação dos profissionais para atuarem nas diferentes atividades vinculadas à educação, assim como a garantia de planos de formação continuada aos profissionais. Enfaticamente, o que hoje soa como um diferencial para determinados sistemas ou redes de educação, tornarse-á uma obrigação legal para a garantia da qualidade na educação brasileira.
} 


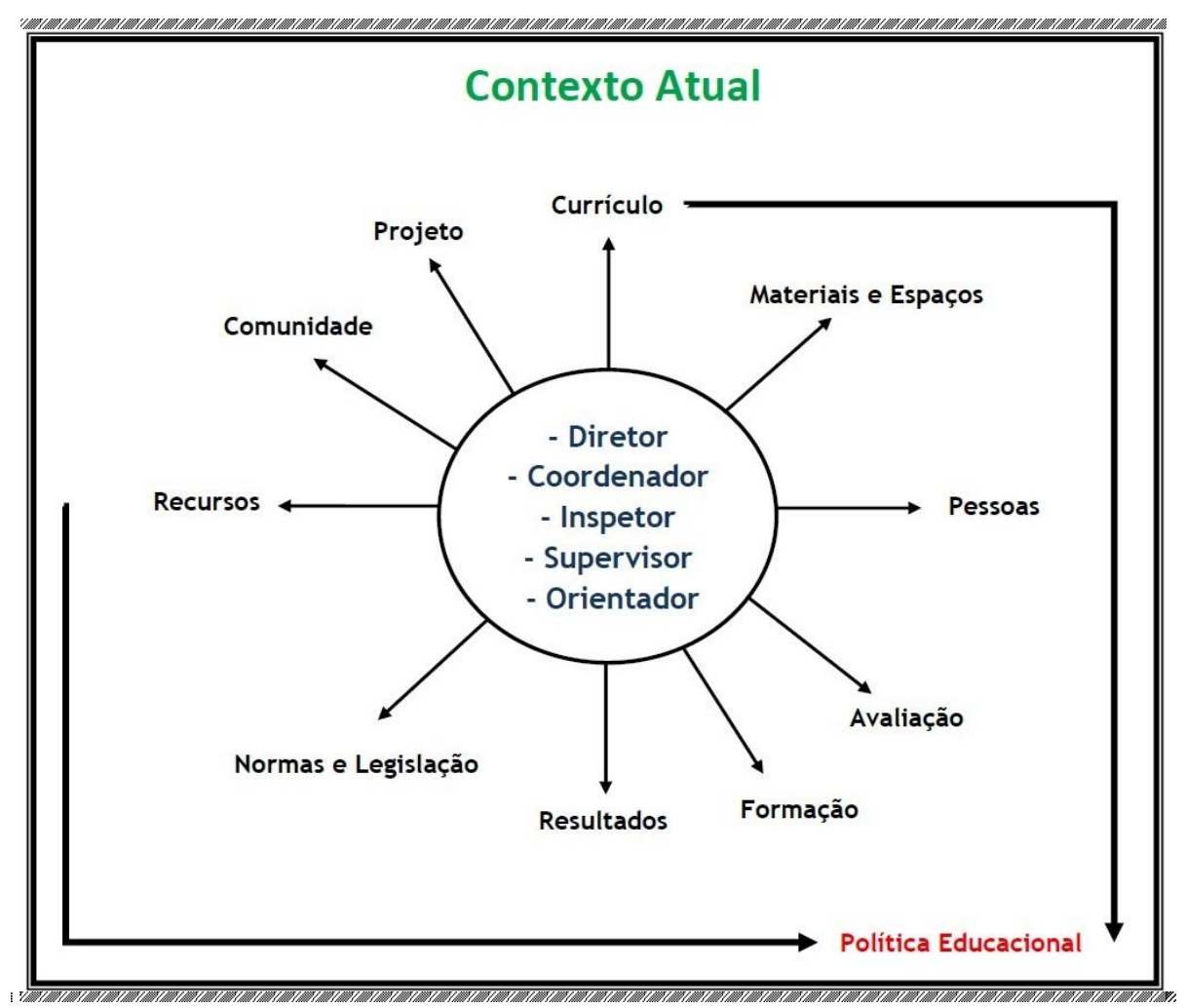

Em contrapartida propomos um modo mais crítico-reflexivo para a organização do trabalho escolar, e atuação dos gestores escolares, numa perspectiva que tenha o projeto pedagógico da escola como fundamento do trabalho e do desenvolvimento educativo, priorizando a construção de uma formação democrática, intelectual e emancipatória para alunos, comunidade e profissionais, o que entendemos como legítimo compromisso público e político da escola: 


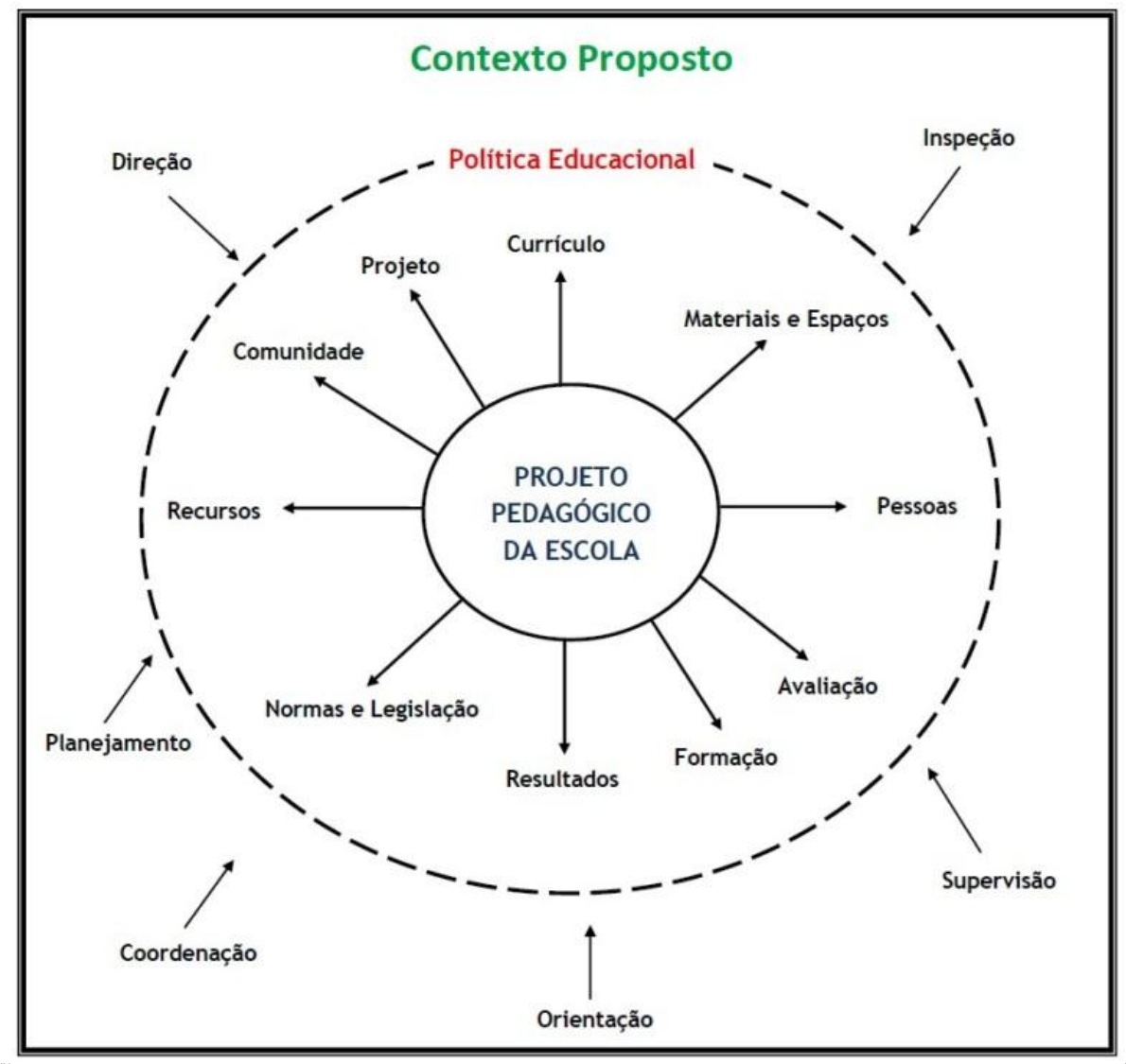

Apesar do anunciado foco na formação pedagógica dos pedagogos, as propostas dos cursos apresentam majoritariamente tratamento segmentado dos conteúdos e dos conhecimentos, o que se reflete na prática escolar em muitos depoimentos.

Aspectos como aplicação de legislação, atividades de formação contínua, mediação das relações e conflitos, ou acompanhamento das políticas públicas na escola são atribuições isoladas de alguns profissionais, ao invés de uma formação e atuação dedicada aos processos e problemas vividos na escola, que poderia superar a cisão entre o fazer e o pensar "o pedagógico".

Outro aspecto vital que defendemos para essa retomada é a disposição de carga horária prevista no curso. Segundo a atual Resolução CNE CP 01/06, a integralização do mesmo ocorrerá em, no mínimo 3.200 horas, contudo o mesmo dispositivo prevê que estas horas serão destinadas a toda formação prevista, incorporando todas as atividades diversificadas para o curso. 
Com esta situação de carga horária e integralização nos cursos de Pedagogia, nos deparamos com tempo excessivamente restrito à formação com atividades baseadas na mediação professor e aluno, por exemplo, em gestão escolar.

Diante da densidade dos estudos a serem realizados e pela importância da diversificação de atividades que devem fazer parte da formação do pedagogo, inclusive dada a complexidade das atividades, sugerimos que as 3.200 horas sejam destinadas às atividades no ambiente acadêmico, para a formação docente, de atuação do pedagogo, e para a gestão, incorporando-se para além destas as demais horas de estágio e prática profissional, atividades complementares, e enriquecimento curricular.

Uma nova modulação para o curso acenaria para a possibilidade de ampliação e aprofundamento das atividades, assim como aumento da relação dos formandos com seus docentes, e o próprio ambiente acadêmico, afastando inclusive a atração para a Pedagogia por uma sensação nefasta de "curso mais rápido", e respondendo, ainda que de certo modo, à intensificação e complexidade da formação, as diversas atribuições dos gestores nas escolas, e na história da Pedagogia, que demonstra algumas das razões da redução temporal do curso ${ }^{85}$.

Por este panorama em relação à carga horária estabelecida para o curso de Pedagogia, que prevê a formação de docentes, de gestores e do pedagogo para outras atividades, não é muito difícil concluir que, ou será formado um professor para atuar em diferentes níveis da docência, ou será formado o

85 O Ministro da Educação Fernando Haddad, em 18/06/2010, aprovou a Portaria Ministerial 808/10, que versa sobre o "Instrumento de avaliação para reconhecimento de Cursos Pedagogia, no âmbito do Sistema Nacional de Avaliação da Educação Superior - SINAES", pelo qual, dispõe que o período mínimo de integralização para os cursos de Pedagogia deverá ser de 4 anos ou 8 semestres. É certo que tal instrumento, isoladamente, não tem capacidade de transformação da realidade dos cursos, nem tampouco poder de lei para frear o acinte de algumas IES em relação ao tratamento dado ao curso, porém, sinaliza a percepção do Ministério acerca da insuficiência dos resultados da modulação ora em vigência, e aponta para um dos indicadores a serem valorados quando do pedido de autorização de funcionamento de novos cursos de Pedagogia. 
gestor escolar, para diferentes ofícios, não obstante o risco de não se formar bem nem um, nem outro. Ainda indagando-nos de "como será formado?". Por outro lado, outra formação implica outro curso de Pedagogia, que seja redesenhado, sob o risco de apenas se oferecer mais do que é frágil, caso não sejam realizadas profundas mudanças curriculares em suas diretrizes.

A ampliação da carga horária do curso deve implicar na melhoria da qualidade das atividades formativas presentes nos cursos, e que subsidiarão o entendimento inicial dos diferentes ofícios da gestão como, por exemplo, os estágios supervisionados e prática profissional, que não podem ser reduzidos a práticas de observação de exercício ou estudo de documentos e registros nas instituições, além da melhoria das condições de formação científica dos pedagogos.

Ademais, melhorar a escola pública tem a ver com melhorar suas condições existenciais, organizacional e seu desenvolvimento, enfim, a compreensão de sua função social, que é foco das práticas de gestão, portanto está relacionado à dialogicidade entre os atores da escola que, sob a base do trabalho pedagógico, deve vinculá-los e não os distanciar.

Pelo valor que atribuímos à dialogicidade e ao reconhecimento da representatividade pelo outro, não julgamos pertinente propostas que remontem exclusivamente ao modelo do bacharelado, que presumiria outro status ao gestor, sob o risco de os afastar do sentido pedagógico fundamental das licenciaturas, que também deve predominar na formação para a gestão escolar e educacional, de modo que também evitemos a idéia de uma Pedagogia para os que podem mais, ou para os que podem menos.

Prontamente, defendemos que as finalidades do curso de Pedagogia, o perfil desejado para o egresso do curso, a diversificação dos campos de atuação possíveis para este profissional, e a complexidade da sua profissionalidade, seja no campo da docência, da gestão, ou da pesquisa, faria do curso de Pedagogia, ao mesmo tempo licenciatura e bacharelado. 
Com estas considerações finais apontamos os principais elementos que corroboram a nossa tese de que os cursos de Pedagogia carecem de nova organização curricular para que seja dado o devido tratamento e atendimento à formação dos gestores escolares, considerando-se principalmente 0 desenvolvimento institucional das escolas.

Intencionamos demonstrar que a presente pesquisa explicita e agrega uma série de conhecimentos, inclusive novos conhecimentos, que podem e devem ser contemplados nos estudos que estiverem relacionados ao processo de formação dos gestores escolares, dentre os quais podemos citar:

a. o movimento legal e pedagógico do curso de Pedagogia, tendo como foco a formação dos especialistas e posteriormente gestores em educação;

b. a concepção de gestão e educação ainda que fragmentária permeia a formação destes profissionais;

c. a estrutura e propostas dos cursos de Pedagogia nos quais estes profissionais são formados;

d. foco formativo dos cursos de Pedagogia e foco de atuação dos profissionais que atuam em ofícios de gestão; e

e. principais dilemas formativos do curso e caminhos apontados para uma nova centralidade pedagógica na formação dos gestores escolares formados no âmbito da Pedagogia.

Com este conjunto de considerações indicamos que esta pesquisa não apenas cumpriu a missão a que se destinou inicialmente, mas permite que realizemos uma conclusão bastante pontual acerca das contribuições possíveis aos pesquisadores da área da educação, aos profissionais que atuam no próprio curso de Pedagogia, e aos próprios gestores escolares, como suporte de reflexão crítica do seu trabalho. 


\section{CONCLUSÃO}

Com base em todas as referências, dados e considerações que já apresentamos, nesta pesquisa, temos que defender que a efetiva contribuição dos gestores escolares para a garantia do desenvolvimento institucional das escolas pública depende de um "outro e novo" lugar da gestão nos cursos de Pedagogia e de profundas mudanças no curso em sua integralidade, ainda que não sejamos indiferentes ao movimento histórico e pedagógico que já tem ocorrido, concluindo:

\section{- O que já foi feito?}

$\checkmark$ A regulamentação da formação dos profissionais responsáveis pelas atividades de suporte pedagógico, ou seja, planejamento, administração, orientação, supervisão, coordenação etc., tanto na Lei de Diretrizes e Bases da Educação, como a disposição de competências para a gestão escolar e educacional, quando das diretrizes curriculares da Pedagogia, indicam a continuidade da transformação histórica do curso, o que certifica a importância da mudança em razão de novas necessidades e demandas.

$\checkmark$ Esta ampliação dos cursos também possibilitou a disseminação da existência do pedagogo na escola e nos sistemas educacionais, passando a fazer parte da cultura educacional, contribuindo, inclusive, para que mesmo nas fragilidades, tais cursos pudessem e possam servir aos sistemas educacionais e redes, considerando algumas de suas peculiaridades, inclusive regionais.

$\checkmark \quad \mathrm{f}$ fato de superarmos, ao menos legalmente, a existência das habilitações que tanto fragmentavam o curso também se coloca como avanço na discussão do curso, trazendo para o interior da Pedagogia esta profissionalização, que reconhece o sentido pedagógico do que 
fazem mesmo aqueles que são especialistas em algum dos ofícios que já trabalhamos exaustivamente.

\section{- O que está sendo feito?}

$\checkmark$ A difusão dos ofícios de gestão escolar nos sistemas escolares tem provocado a diversificação do currículo nos cursos de Pedagogia, o que provoca, ao mesmo tempo, a busca da identidade dos pedagogos e relativização desta gestão numa proposta mais política pedagógica, ou contrariamente, mais racionalista;

$\checkmark$ Esta ambigüidade tem contribuído para as muitas pesquisas que discutem o conceito de gestão no âmbito escolar, assim como a profissionalidade dos sujeitos, diante das condições com as quais se deparam na escola, o que implica na insatisfação dos mesmos com o que está prescrito teoricamente sobre o que se espera de seu trabalho, as condições e propósitos sob as quais as atividades de gestão se assentam, e finalmente o que conseguem concretizar. Isto provoca a permanente reflexão acerca do que é ser gestor escolar, principalmente para os que o são;

$\checkmark$ Emerge também do alarido provocado pelos profissionais que já atuam nos ofícios de gestão, a demanda de se colocar a identidade e perfil de tais profissionais no palco da construção das carreiras do magistério nos vários sistemas de ensino, vinculando-se esta discussão aos seus fazeres, saberes e experiências, além das condições reais de exercício do trabalho. Neste caso se coloca a importância da discussão de outra carreira para os pedagogos, os professores, e todo o magistério;

$\checkmark$ No âmbito da academia, embora ainda careçamos de ampliação das pesquisas relacionadas à formação dos gestores escolares, tem ocorrido uma série de movimentos relacionados à compreensão do papel dos 
gestores na escola, e a relação do seu processo de formação inicial e a sua profissionalidade;

$\checkmark$ Por conseguinte há um fortalecimento nos estudos, trabalhos e movimentos que denunciam as fragilidades dos atuais cursos de Pedagogia que estão rendidos às lógicas que não são necessariamente comprometidas com a melhoria da educação para todo a povo, tarefa mais legítima e sublime da escola pública, onde atua a maior parte destes profissionais;

$\checkmark$ Temos como resultante desta situação uma insatisfação generalizada em relação ao saldo do trabalho na escola pública, em relação aos indicadores de avaliação e aprendizagem, que são intencionalmente divulgados, ou às condições de trabalho que impedem 0 profissionalismo desejado, ou finalmente ao atendimento às expectativas e necessidades da comunidade escolar;

$\checkmark$ Tem se intensificado o volume de pesquisas sobre a educação, e principalmente aquelas que reconhecem a escola como lócus privilegiado, ao mesmo tempo complexo e orgânico, de ensino, de aprendizagem e também de formação, tanto para alunos como professores, e neste caso, de gestores escolares.

$\checkmark$ Este movimento apóia o entendimento de que a formação do pedagogo para atuar em espaços educativos tão complexos não reside apenas no campo da docência, mas vincula-se à concepção de sociedade e educação, as políticas educacionais, a pesquisa e investigação educativa, e a compreensão da ciência educação, portanto implica em saberes que vão além da formação para a docência, assim dizendo, não se registre as saberes da licenciatura. 


\section{- O que há de se fazer?}

$\checkmark$ A trajetória que percorremos, nesta pesquisa, nos faz crer que apesar de termos avançado no sentido da discussão da identidade do curso de Pedagogia, e também dos pedagogos em diferentes campos de atuação na escola, para o que destacamos principalmente: a reorientação dos cursos de Pedagogia, com o objetivo de analisar o espaço e lugar da formação dos gestores nos currículos dos cursos; assim como a concepção de gestão que se constitui a partir do conjunto de elementos presentes;

$\checkmark$ Outro aspecto que julgamos fundamental é a análise do tempo de integralização e carga horária dos cursos de Pedagogia com as atividades que atualmente já estão propostas, com a indicação de ampliação do tempo de curso, sobretudo das atividades realizadas na academia, para que haja maior equilíbrio entre a profissionalização para o campo da docência e os demais ofícios do pedagogo;

$\checkmark$ A retomada dos currículos dos cursos, considerando também as demandas que são apresentadas pelos profissionais já em exercício, com a intenção de se superar o abismo entre a teoria e a prática, tanto no campo do discurso educacional, quanto no âmbito da profissionalidade, valorizando-se assim o projeto pedagógico da escola, que demonstra sua auto-representação, contribuindo para o desenvolvimento profissional e institucional;

$\checkmark$ Fortalecer a reivindicação de posicionamento do Ministério da Educação, e dos Conselhos Estaduais de Educação, no que se refere às deliberações e normatizações relacionadas ao curso de Pedagogia, enfatizando a urgência da reorientação curricular do curso (tempo, integralização, carga horária, modalidade de oferta, currículo, fomento, etc.), e reavaliando Diretrizes Nacionais como parâmetros mínimos de efetivação das propostas formativas nos cursos nas Instituições de 
Ensino Superior, evitando que autonomia e flexibilidade, não sejam adotadas como liberalidade e celeridade perversa;

$\checkmark$ É imperativo que consigamos romper com um processo de cumprimento de ações e iniciativas compensatórias e supletivas relacionadas à organização, oferecimento e funcionamento dos cursos, e que demonstram tão somente, a ausência de investimentos reais e permanentes, além da escassa política valorização da formação dos pedagogos, assim como das demais licenciaturas no Brasil, e que muitas vezes acenam apenas para a melhoria de dados estatísticos;

$\checkmark$ Como já apontamos nesta pesquisa, aprofundar-se as discussões, estudos e levantamentos acerca da suficiência de elementos formativos presentes em cursos de licenciatura, modalidade na qual a Pedagogia está integralmente inserida, uma vez que o próprio perfil do egresso, e as exigências da educação, indicam a necessidade da apropriação de outros conteúdos complexos a partir da formação inicial, ou seja, é uma formação que está além da concepção clássica de licenciatura, o que aponta para um modelo de formação mais particularizado, como ocorre em outras carreiras;

$\checkmark$ Apontamos também como fundamental a contínua mobilização do meio acadêmico no sentido de manter e ampliar as pesquisas no campo da formação dos gestores escolares, especificamente na Pedagogia, mas analisando também os elementos que circunstanciam seu trabalho: modos de pensar seu trabalho, e atuação e as condições de exercício, os processos de formação continuada que têm acesso, e a própria carreira destes profissionais, isto porque são fatores que influenciam sua profissionalidade.

Ademais, enfatizamos que as mudanças ora defendidas são consideradas como fundamentais num outro olhar possível para a gestão no curso de Pedagogia, mantendo-se a essência das 
licenciaturas, mas reportando-se também aos elementos que constituem os currículos dos bacharelados, apresentando-se a formação do pedagogo como um caráter próprio e específico na graduação, assegurando-se a manutenção do foco do desenvolvimento dos conhecimentos e saberes pedagógicos, integrando as vertentes da pesquisa, da ciência e da atuação além dos muros da escola.

Entendemos que, defender o processo de discussão, reivindicação, seguido de proposições para outro curso de Pedagogia, formador de gestores, é também revigorar a contribuição que esta formação têm para se concretizar um trabalho efetivamente com qualidade na escola pública, e neste caso, sublinhando os valores éticos e políticos que precisam orientar esse nosso compromisso público.

Concluímos esta pesquisa, com o propósito de que tenhamos trazido reflexões acerca dos desafios que ora nos são apresentados e precisam ser considerados no campo da gestão pedagógica, e posições que defendemos para a mudança no trabalho de formação dos gestores escolares, de maneira que tenham oportunidades mais promissoras de atuarem para a melhoria e desenvolvimento das instituições escolares.

Neste sentido defendemos que compreender "o que já foi feito" valorizou os estudos teóricos e as iniciativas práticas que até o momento caracterizaram o curso e a formação dos gestores; destacar "o que está sendo feito", pode apoiar as pesquisas em desenvolvimento e os debates acerca do curso de Pedagogia e do trabalho dos gestores, e finalmente "o que temos a fazer" mobilizará outros profissionais e pesquisadores para a tarefa de refletir sobre a construção de outra identidade necessária para a formação dos gestores nos cursos de Pedagogia.

Assim, acreditamos ter contribuído para as pesquisa sobre a formação dos gestores escolares no âmbito dos cursos de Pedagogia, além de ter suscitado a importância e o interesse de futuras pesquisas nesta área. 


\section{REFERÊNCIAS}

ACÁCIO, Maria de Lourdes Bezerra. A formação do Pedagogo na UFAC: dúvidas e fantasias na implantação do outro currículo de pedagogia. Dissertação de Mestrado. Universidade Federal do Rio de Janeiro. Rio de Janeiro: 1999.

AGUIAR, M. A; BRZEZINSK, I.; FREITAS, H. C. L.; SILVA, M. S.; PINO, R. I. Diretrizes Curriculares do curso de Pedagogia no Brasil: disputas de projetos no campo da formação profissional da educação. Educação \& Sociedade. Campinas-SP, v. 27, n. 96, Especial, p. 819-842, out. 2006.

ALARCÃO, Isabel (Org.). Formação Reflexiva de Professores - estratégias de supervisão. Porto-PT: Porto Editora, 1996.

; TAVARES, José. Supervisão da Prática Pedagógica - uma perspectiva de desenvolvimento e aprendizagem. 2 ed. Coimbra: Almedina, 2007.

ALMEIDA, Ana Luiza Melo de. O Pedagogo Especialista em Educação origem e extinção na política educacional brasileira. Dissertação de Mestrado. Universidade Federal de Sergipe, São Cristovão - Sergipe, 2008.

ALMEIDA, Laurinda R. de; PLACCO, Vera Maria Nigro de Souza. O Coordenador Pedagógico. São Paulo-SP: Edições Loyola, 2001.

ALMEIDA, Maria I. O sindicato como instância formadora dos professores: novas contribuições ao desenvolvimento profissional. Tese de Doutorado. Faculdade de Educação. Universidade de São Paulo, São Paulo, 1999. ; Maria I; RUÉ, Joan. Educação e Competências. São Paulo: Summus, 2009.

ALTER, Marguerite; PERRENOUD, Phillippe; PAQUAY, Leopold, et al. A profissionalização dos formadores de professores. Porto Alegre: ARTMED, 2003.

ALVES, Nilda (Org.). Formação de Professores: Pensar e Fazer. 7. ed. São Paulo: Cortez, 2002.

ANDRÉ, Marli (Org.). O papel da pesquisa na formação e na prática dos professores. 2. ed. Campinas-SP: Papirus, 2001.

Marli E. A. D. A pesquisa no cotidiano escolar. In: FAZENDA, Ivani. Metodologia da pesquisa educacional. 8. ed. São Paulo: Cortez Editora, 2002. 
ARDOINO, J. A Nota a propósito das relações entre a abordagem multirreferencial e a análise institucional (história ou histórias). In. BARBOSA, J.G. (Coord.) Multirreferencialidade nas ciências da educação. São Carlos: Editora UFSCar, 1998.

ARENDT, Hannah. Entre o passado. São Paulo: Perspectiva, 2009.

ARROYO, Miguel G. Ofício de Mestre - imagens e auto-imagens. 5. ed. Petrópolis-RJ: Editora Vozes, 2000.

ASSIS, Ana Elisa Spaolonzi Queiroz. Especialistas, Professores e Pedagogos: Afinal, que profissional é formado na pedagogia?. Dissertação de Mestrado. PUC-Campinas, São Paulo, 2007.

ASSMANN. Hugo. (Org). Reencantar a educação: rumo à nova sociedade aprendente. 8. ed. Rio de Janeiro: Editora Vozes, 2004.

AZANHA, José Mário P. Educação: temas polêmicos. São Paulo: Martins Fontes, 1995.

BARBIER, R. A pesquisa ação na instituição educativa. Rio de Janeiro: Editora Jorge Zahar, 1985.

BARBOSA, J. G. Multirreferencialidade nas ciências da educação. São Carlos: Editora UFSCar, 1998.

Reflexões em torno da abordagem multirreferencial. São Carlos: Editora UFSCar, 1998.

BORGES, Heloisa da Silva. Organização do Trabalho Pedagógico e Gestão Escolar. Manaus: Edições UEA Ed. Valer, 2008.

BRUNER, Jerome. A Cultura da Educação. Porto Alegre: ARTMED, 2001.

BRZEZINSKI, Iria. Pedagogia, pedagogos e formação de professores. Campinas-SP: Papirus, 1996.

Profissão Professor: Identidade e Profissionalização Docente.

Brasília: Plano Editora, 2002.

CAMBI, Franco. História da Pedagogia. São Paulo: Fundação Editora da UNESP, 1999.

CAMPOS, Roselane Fátima. A reforma da formação inicial dos professores da educação básica nos anos de 1990 - desvelando as tessituras da 
proposta governamental. Tese de Doutorado. Centro de Ciências da Educação. Universidade Federal de Santa Catarina. Florianópolis, 2002. Mimeografado.

. Fazer mais com menos - Gestão Educacional na perspectiva da CEPAL e da UNESCO. Painel da $28^{\circ}$ Reunião Anual da ANPED. Caxambu, 2005. Disponível em <http://www.anped.org.br/28/inicio/htm>. Acesso em: 2 de jun de 2006.

CANÁRIO, Rui. (Org.). Formação e situações de trabalho. Porto-PT: Porto Editora, 2003.

CASASSUS, Juan. Tarefas da Educação. Campinas- SP: Autores Associados, 1995.

CASTELLS, Manuel; FLECHA, Ramón; FREIRE, Paulo; GIROUX, Henry; MACEDO, Donaldo; WILLIS, Paul. Novas Perspectivas Críticas em Educação. Porto Alegre: Artes Médicas, 1996.

CHUCHENE, Amélia Ciscato. Uma análise do Curso de Pedagogia da Pontifícia Universidade Católica do Paraná: legislação, possibilidades e ações concretas. Dissertação de Mestrado. Pontifícia Universidade Católica do Paraná. Curitiba: 2001.

COELHO, I. M. Curso de Pedagogia: a busca da identidade. INEO. Série Encontros e Debates. Brasília, 1987.

CONTRERAS, José. A autonomia de professores. São Paulo: Cortez, 2002.

CORAZZA, Sandra M. Labirintos da pesquisa, diante dos ferrolhos. In: COSTA, Marisa V. Caminhos investigativos I - novos olhares na pesquisa em educação. 3. ed. Rio de Janeiro: Editora Lamparina, 2002.

CRÓ, Maria de Lurdes. Formação Inicial e Contínua de Educadores/ Professores - estratégias de intervenção. Porto-PT: Porto Editora, 1998.

DAY, Christopher. Desenvolvimento profissional dos professores - os desafios da aprendizagem permanente. Porto-PT: Porto Editora, 2001.

DELORS, Jaqcques. Educação um tesouro a descobrir. 6. ed. Brasília-DF: MEC; UNESCO, 2001.

DEMO, Pedro. A Educação do Futuro e o Futuro da Educação. CampinasSP: Autores Associados, 2005.

DUBAR, Claude. A socialização: construção das identidades sociais e profissionais. Porto-PT: Porto Editora, 1997. 
. Formação, trabalho e identidades profissionais. In: CANÁRIO, R.

Formação e situações de trabalho. Porto-PT: Porto Editora, 2003.

ENGUITA, Mariano Fernández. Educar em Tempos Incertos. Porto Alegre: ARTMED, 2004.

ESTEBAN, Maria Teresa; ZACCUR, Edwiges (Org.). Professora pesquisadora - uma práxis em construção. Rio de Janeiro: DP\&A Editora, 2002.

EVANGELISTA, Olinda: SHIROMA, Eneida Oto. As políticas internacionais para a educação e suas repercussões no Brasil. Florianópolis: UFSC/PPGE, 1999. Mimeografado.

. Profissionalização como estratégia de gerenciamento de professores. Revista de Estudos Curriculares. Braga PT, Ano 1, n,2, 2003, p.267-281.

. Um fantasma ronda o professor: a mística da competência. In.: MORAES, Maria Célia (Org.) lluminismo as avessas: produção de conhecimento e políticas de formação docente. Rio de Janeiro: DP\&A, 2003.

FERNANDEZ, Maria Elizabete dos Santos. Função do Gestor na Escola Pública. Revista de Divulgação técnica - cientifica do ICPG, Vol.3, n.9, juldez/2006.

FERREIRA, Naura Syria C. (Org.).Educacional para uma Escola de Qualidade. 3. ed. São Paulo: Editora Cortez, 2002.

; BITTENCOURT, Agueda Bernadete (Org.). Formação humana e gestão da Educação. São Paulo: Cortez, 2008.

Supervisão Educacional. 14. ed. Petrópolis-RJ: Editora Vozes, 2009.

FORMOSINHO, João; ARAUJO, Joaquim M. O anônimo do século $X X-a$ construção da pedagogia burocrática. In: Pedagogia(s) da Infância:

dialogando com o passado, construindo o futuro. Porto Alegre: ARTMED, 2007.

FORMOSINHO, Júlia Oliveira; KISHIMOTO, Tizuko Morchida; PINAZZA, Mônica Appezzato. (Org.). Pedagogia(s) da Infância. Porto Alegre: ARTMED, 2007.

FORTUNATI, José. Gestão da Educação Pública. Porto Alegre: ARTMED, 2007. 
FOUCAULT, Michel. Microfísica do Poder. 22. ed. Rio de Janeiro: Edições Graal, 1976.

FRANCISCO, Iraci J. A Atuação do Diretor de Escola Pública:

Determinações Administrativas e Pedagógicas do Cotidiano Escolar.

Dissertação de Mestrado. PUC SP, 2006.

FRANCO, Maria A; LIBANEO, José C; PIMENTA, Selma G. Elementos para a formulação de diretrizes curriculares para cursos de Pedagogia. In: Cadernos de Pesquisa da Fundação Carlos Chagas. São Paulo: Autores Associados, jan/abril 2007, v. 37, n.130, p. 63-97.

Pedagogia como ciência da educação. São Paulo: Cortez, 2008.

FREIRE, Paulo. Educação e Atualidade Brasileira. 3. ed. São Paulo: Cortez; Instituto Paulo Freire, 2003.

FREITAS, Helena Costa L. de. A formação inicial e continuada dos profissionais da educação. IN: SILVA, Aida M. M; AGUIAR, Maria A. da S. (Org). Retrato da escola no Brasil. Brasilia: CNTE, 2004, p. 81-104.

A reforma do ensino superior no campo de formação dos profissionais da educação básica: as políticas educacionais e o movimento dos educadores. In.: Educação e Sociedade, Ano XX, n. 68, dezembro de 1999, p.17-44.

. Certificação docente e Formação do Educador: Regulação e Desprofissionalização. In: Educação e Sociedade: Campinas-SP, v. 24, n.85, p.1095-1124, dezembro 2003. Disponível em: <http://www.cedes.unicamp.br>. Acesso em 10 ago. 2006.

. Formação de Professores no Brasil: 10 anos de embate entre projetos de formação. In: Educação e Sociedade, v. 23, n. 80, p. 137-168, set. de 2002.

FRIGOTTO, Gaudêncio; CIAVATTA, Maria. Educação Básica no Brasil na Década de 1990: Subordinação ativa e concedida a lógica do mercado. In: Educação e Sociedade V. 24 n.82, p 90-130, Abril de 2003.

A produtividade da Escola improdutiva: um (re)exame das relações entre educação e estrutura econômico-social capitalista. São Paulo: Cortez, Autores Associados, 1984. (Coleção Educação Contemporânea).

. Os delírios da razão: crise do capital e metamorfose conceitual no campo educacional. In: GENTILI P. (Org.) Pedagogia da exclusão: o neoliberalismo e a crise da escola pública. Petrópolis, RJ: Vozes, 1995. (Coleção Estudos Culturais em Educação). 
FULLAN, Michael. O significado da mudança educacional. Porto Alegre: ARTMED, 2009. ; HARGREAVES, Andy. Por que é que vale a pena lutar? O trabalho da equipa na escola. Porto-PT: Porto Editora, 2001. . Liderar numa cultura de mudança. Porto-PT: Edições ASA, 2003.

GADOTTI, M. História das idéias pedagógicas. 4. ed. São Paulo, SP: Ática, 1996.

GARCIA, Carlos M. A formação dos professores: novas perspectivas baseadas na investigação sobre o pensamento do professor. In: Os professores e sua formação. Lisboa: Dom Quixote, 1992.

Porto Editora, 1999.

Formação de professores para a mudança educativa. Porto:

GIROUX, H. A. Os professores como intelectuais: rumo a uma pedagogia crítica da aprendizagem. Porto Alegre: ARTMED, 1997.

GATTI, Bernadete A. A construção da pesquisa em educação no Brasil. Brasília: Editora Plano, 2002.

Formação de Professores e Carreira. 2. ed. Campinas-SP: Autores Associados, 2000.

; BARRETTO, Elba de Sá S. Professores do Brasil: impasses e desafios. Brasília: UNESCO, 2009.

GAUTHIER, Clermont; MARTINEAU, Stéphane; DESBIENS, Jean-François; MALO, Annie; SIMARD, Denis. Por uma Teoria da Pedagogia. 2. ed. ljuí: Editora Unijuí, 2006.

GENTILI, Pablo. A falsificação do consenso: simulação e imposição na reforma educacional do neoliberalismo. Petrópolis: Vozes, 1998.

Políticas educacionais no contexto do neoliberalismo: os significados da privatização no campo educacional. In. OLIVEIRA, Maria Neusa de. As políticas educacionais no contexto da globalização. Ilhéus: Editus, 1999.

; SUÁREZ, Daniel (organizadores). Reforma educacional e luta democrática. São Paulo: Cortez, 2004. 
GERALDI, Corinta M. G.; FIORENTINI. Dario; PEREIRA. Elisabete M. de A. Cartografias do trabalho docente. Campinas-SP: Mercado das Letras, 1998.

GHEDIN, Evandro; FRANCO, Maria A. S. Pesquisa em educação: alternativas investigativas com objetos complexos - introdução. In: Pesquisa em educação: alternativas investigativas com objetos complexos. São Paulo: Loyola, 2006.

GLATTER, Ron. A Gestão como Meio de Inovação e Mudança nas Escolas. In NOVOA, Antonio. (Coord.). As Organizações Escolares em Análise. Lisboa: Publicação Dom Quixote, 1992.

GONZAGA, Amarildo M. A pesquisa em educação: um desenho metodológico centrado na abordagem qualitativa. In: Pesquisa em educação: alternativas investigativas com objetos complexos. São Paulo: Loyola, 2006.

HARGREAVES, Andy; EARL, Lorna; MOORE, Shawn; MANNING, Susan. Aprendendo a Mudar - $O$ ensino para além dos conteúdos e da padronização. Porto Alegre: ARTMED, 2002.

. Educação para Mudança. Porto Alegre: ARTMED, 2001.

HENGEMUHLE, Adelar. Gestão de Ensino e Práticas Pedagógicas. Petrópolis-RJ: Vozes, 2004.

HORA, Dinair L. da. Gestão Democrática na Escola. 5. ed. Campinas-SP: Papirus, 1994.

IMBERNÓN, Francisco. A Educação do Século XXI. 2. ed. Porto Alegre: ARTMED, 2000.

1994.

. La formacion Del profesorado. Barcelona: Ediciones Paidós,

JOBERT, Guy. A profissionalização: entre a competência e o reconhecimento social. In: A profissionalização dos formadores de professores. Porto Alegre: ARTMED, 2003.

KUENZER, Acácia Zeneida. As políticas de formação: a construção da identidade do professor sobrante. Educação \& Sociedade [online], dez. 1999, v. 20, n. 68, p.163-183. Disponível em: < http://www.scielo.br/scielo.php?pid=S010440362005000400005\&script=sci arttext>. Acesso em: 23 de nov. de 2005. . RODRIGUES, Marli de Fátima. As diretrizes curriculares para o curso de Pedagogia: uma expressão da epistemologia da prática. In: Novas subjetividades, currículos, docência e questões pedagógicas na 
perspectiva da inclusão social / Encontro Nacional de Didática e Prática de Ensino, Recife: ENDIPE, 2006.

LEITE, S. A. S. O papel dos 'especialistas' na escola pública. In: Educação e sociedade. Campinas-SP: CEDES, v. 22, 1985, p. 120-131.

LIBANEO, José C. Ainda as perguntas: o que é a Pedagogia, quem é o pedagogo, o que deve ser o curso de Pedagogia. IN: PIMENTA, Selma G. Pedagogia e Pedagogos - caminhos e perspectivas. São Paulo: Cortez Editora, 2002.

Democratização da Escola Pública - a pedagogia crítico-social dos conteúdos. São Paulo: Edições Loyola, 1985.

. Organização e gestão da escola: teoria e prática. Goiânia:

Editora Alternativa, 2004.

. Pedagogia e pedagogos para quê? 12. ed. São Paulo: Cortez Editora, 2010.

. Pontos críticos dos atuais cursos de Pedagogia. IN: Revista Presença Pedagógica. Belo Horizonte: v.11, n. 65, set/out 2005.

Que destino os educadores darão à Pedagogia? IN: PIMENTA, Selma G. Pedagogia, ciência da educação? São Paulo: Cortez, 2001. .; OLIVEIRA, João Ferreira de; TOSCHI, Mirza Seabra. Educação Escolar: políticas, estrutura e organização. 2. ed. São Paulo: Cortez, 2005.

LIMA, Emília Freitas. O curso de pedagogia e a nova LDB: vicissitudes e perspectivas. In: MIZUCAMI, Maria da Graça; REALI, Aline Maria de Medeiros (Org.). Formação de Professores: práticas pedagógicas e escolas. São Carlos: EDUFScar, 2002.

LIMA, Jorge Ávila de. As Culturas Colaborativas nas Escolas. Porto-PT: Porto Editora, 2002.

LISTON, D.P.; ZEICHNER, K.M. Formación del profesorado y condiciones sociales de la escolarización. Madri: Ediciones Morata, 1993.

LOMBARDI, José Claudinei; SAVIANI, Dermeval; NASCIMENTO, Maria Isabel Moura (Org.). A escola pública no Brasil. Campinas-SP: Autores Associados, 2005.

LÜCK, Heloísa. Gestão educacional: uma questão paradigmática. 2. ed.

Petrópolis: Vozes, 2007. 
Dimensões da gestão escolar e suas competências. Curitiba:

Editora Positivo, 2009.

LUNA, Sérgio. V. Planejamento de pesquisa: uma introdução. 7. ed. São Paulo: Educ, 2002.

MACIEL, Lizete Shizue Bomura; NETO, Alexandre Shigunov (Org.). Formação de Professores - passado, presente e futuro. São Paulo: Cortez, 2004.

MARAFON, Maria Rosa Cavalheiro; MACHADO, Vera Lúcia de Carvalho. Contribuição do Pedagogo e da Pedagogia para a Educação Escolar. Campinas-SP: Editora Alínea, 2005.

MARCH, Luciana Cazarini Lima de. A Formação e a Identidade Profissional do Gestor Escolar da Rede Pública de Ensino Paulista. Dissertação de Mestrado. Mogi das Cruzes: UBC, 2008.

MARQUES, Mario Osorio. Formação do Profissional da Educação. 4. ed. ljuí: Editora Unijuí, 2003.

MC LAREN, Peter. A vida nas Escolas - uma introdução. Porto Alegre: ARTMED, 1977.

MENESES, João Gualberto de Carvalho (Org). Estrutura e Funcionamento da Educação Básica. 2. ed. São Paulo: Pioneira Thomson Learning, 1998/1999.

MORIN, Edgar. Os sete saberes necessários à educação do futuro. São Paulo: Cortez Editora, 2002.

MORIN, Edgar; ALMEIDA, Maria da Conceição de; CARVALHO, Edgard de Assis. (Org.). Educação e Complexidade: Os sete saberes e outros ensaios. 3. ed. São Paulo: Cortez: 2005.

MOTTA, Artur Guilherme Carvalho da. Gestão Pedagógica e docência - o trabalho do professor como experiência social. Tese de Doutorado. Pontifícia Universidade Católica do Rio de Janeiro, RJ, 2006.

NOVOA, Antonio. As ciências da educação e os processos de mudança. IN: PIMENTA, Selma G. Pedagogia, ciência da educação?. São Paulo: Cortez Editora, 2001. 1995. . Os professores e sua formação. 2. ed. Lisboa: Dom Quixote, . Vida de Professores. 2. ed. Porto-PT: Porto Editora, 2000. 
OLIVEIRA, Dalila A; ROSAR, Maria de F. F. (Org.). Política e Gestão da educação. Belo Horizonte: Editora Autêntica, 2008.

. As reformas educacionais e suas repercussões sobre o trabalho docente. In: OLIVEIRA, Dalila Andrade. (Org.). Reformas educacionais na América Latina e os trabalhadores docentes. Belo Horizonte: Autêntica, 2003.

OLIVEIRA, Dalila, A. Mudanças na organização e na gestão do trabalho na escola. IN: OLIVEIRA, Dalila A; ROSAR, Maria de F. F. (Org.). Política e Gestão da educação. Belo Horizonte: Editora Autêntica, 2008.

OLIVEIRA, João Ferreira; FONSECA, Marília; TOSCHI, Mirza. Educação, gestão e organização escolar: concepções e tendências atuais. In: OLIVEIRA, João Ferreira. (Org.). Escolas gerenciais: planos de desenvolvimento e projetos políticos-pedagógicos em debate. Goiânia: UCG, 2004.

PARO, Vitor H. Crítica da estrutura da escola. São Paulo: Cortez Editora, 2011.

. Administração escolar: à luz dos clássicos da Pedagogia. São Paulo: Cortez Editora, 2011.

. Educação como exercício do poder. São Paulo: Cortez Editora, 2010.

Administração escolar: introdução crítica. São Paulo: Cortez Editora, 2008.

Paulo: Ática, 2007.

Gestão Escolar, democracia e qualidade do ensino. São

PEREIRA, Júlio Emílio Diniz. Formação de Professores-pesquisas, representações e poder. Belo Horizonte: Autêntica, 2000.

PERRENOUD, Phellippe. 10 Novas Competências para Ensinar. Porto Alegre: ARTMED, 2000.

ARTMED, 1999.

Construir as Competências desde a Escola. Porto Alegre:

A divisão de trabalho entre formadores de professores: desafios emergentes. In: A profissionalização dos formadores de professores. Porto Alegre: ARTMED, 2003. 
PIMENTA, Selma G. (Coord.) . Pedagogia, ciência da educação?. São Paulo: Cortez, 2001.

. (Org.). Saberes Pedagógicos. São Paulo: Cortez, 2002.

. Pedagogia e Pedagogos - caminhos e perspectivas. 2. ed. São

Paulo: Cortez Editora, 2002.

.; Ghedin, Evandro. (Org.). Professor Reflexivo no Brasil gênese e crítica de um conceito. São Paulo: Cortez, 2002.

PINTO, Umberto de A. Os cursos de complementação pedagógica e a formação dos pedagogos na cidade de São Paulo (1970-2000). Dissertação de Mestrado. PUC SP. São Paulo, 2000.

.. Pedagogia e Pedagogos Escolares. Tese de Doutorado.

Faculdade de Educação da Universidade de São Paulo, 2006.

.. Pedagogia Escolar - Coordenação Pedagógica e Gestão

Educacional. São Paulo: Cortez Editora, 2011.

POPKEWITZ, Thomas S. Lutando em Defesa da Alma: a política do ensino e a construção do professor. Porto Alegre: ARTMED, 2001.

POZO, Juan Ignacio. Aprendizes e Mestres - a nova cultura da aprendizagem. Porto Alegre: ARTMED, 2002.

QUELUZ, Ana Gracinda; ALONSO, Myrtes. (Org.). 0 Trabalho Docente teoria e prática. São Paulo: Pioneira Thomson Learning, 2003.

RANGEL, Mary. Considerações sobre o papel do supervisor, como especialista em educação, na América Latina. IN: SILVA JR, Celestino; RANGEL, Mary. Nove olhares sobre a supervisão. 9. ed. Campinas-SP: Papirus Editora, 2003.

REIS, Reinildes Maria de Carvalho dos. O Perfil do Pedagogo em Formação nos Cursos de Pedagogia em Goiânia. Dissertação de Mestrado.

Universidade Católica de Goiás, Goiânia, 2006.

RIBEIRO, Henrique; DORNELAS, Evellyn. Diretrizes Curriculares Nacionais do Curso de graduação em pedagogia: entidades nacionais de educação x CNE. In: Revista Eletrônica Trabalho em Perspectiva. n. 2, 2006.

RIOS, Terezinha A. Compreender e Ensinar - por uma docência da melhor qualidade. 2. ed. São Paulo: Cortez, 2001.

SÁ-CHAVES, Idália. (Org.). Percursos de Formação e Desenvolvimento

Profissional. 3. ed. Porto-PT: Porto Editora, 1997. 
SACRISTÁN, J. Gimeno; GÓMEZ, A. L. Pérez. Compreender e Transformar o Ensino. 4. ed. Porto Alegre: ARTMED, 1998.

Poderes instáveis em educação. Porto Alegre: ARTMED, 2009.

SANTOS, Clóvis Roberto dos. O Gestor Educacional de uma escola em mudança. São Paulo: Pioneira Thomson Learning, 2002.

SAVIANI, Dermeval. A nova lei da educação. 11. ed. Campinas-SP: Autores Associados, 2008

A Pedagogia no Brasil. Campinas-SP: Autores Associados,

2008. História da formação docente no Brasil: três momentos decisivos.

In: Revista Centro de Educação. Santa Maria, v.30, n. 02, p.11-26, 2005.

Disponível em: <www.ufsm.br/ce/revista>. Acesso em: 3 de jun. 2006.

. O espaço acadêmico da pedagogia no Brasil. Perspectiva

histórica. In: Revista Paidéia. v. 14, n. 28, 2004. Disponível em:

<http://sites.ffclrp.usp.br/padidera/artigos/28.htm> Acesso em: 20 abr. 2007.

. Sentido da Pedagogia e o papel do pedagogo. In: Revista da

Associação Nacional de Educação, ano 5, n.9, 1985.

SCHEIBE, Leda. Diretrizes Curriculares para o Curso de Pedagogia: trajetória longa e inconclusa. Cadernos de Pesquisa, v. 37, n. 130, p. 43-62, 2007. Disponível em: <http://www.scielo.br/pdf/cp/v37n130/04.pdf>. Acesso em: 3 jun. 2008.

. Formação dos profissionais da educação pós LDB: vicissitudes e perspectivas. IN: VEIGA, IIma P. A; AMARAL, Ana Lúcia. (Org.). Formação de professores: políticas e debates. Campinas-SP: Papirus, 2002.

- O curso de Pedagogia no embate entre concepções de formação. In: GUIMARÃES, Valter Soares. Formar para o mercado ou para a autonomia? - o papel da universidade. Campinas-SP: Papirus, 2006.

O projeto de profissionalização docente no contexto da reforma educacional iniciada nos anos 1990. Revista Educar, n. 24, p. 177-193, 2004. Disponível em: < http://ojs.c3sl.ufpr.br/ojs/index.php/educar/article/view/2214>. Acesso em: 16 ago. 2007. 
SCHON, Donald A. Educando o Profissional Reflexivo - um novo design para o ensino e a aprendizagem. Porto Alegre: ARTMED, 2000.

SERGIOVANNI, Thomas J. O mundo da mudança: desenvolver culturas, práticas e responsabilidade pessoal nas escolas. Lisboa: Edições ASA, 2004.

SERRANO, Gloria P. Investigacion cualitativa. Retos e interrogantes: técnicas y analisis de datos. Madrid: Ediciones Murata, 1998.

SEVERINO, Antônio J.; FAZENDA, Ivani C. A. (Org.). Formação Docente: rupturas e possibilidades. Campinas-SP: Papirus, 2002.

SHIROMA, Eneida Oto. Implicações da política de profissionalização sobre a gestão e o trabalho docente. 2004. Disponível em:

$<$ www.gepeto.ced.ufsc.br>. Acesso em: 24 fev. 2007.

. O eufemismo da profissionalização. In: MORAES, Maria Célia Marcondes. lluminismo às avessas: produção de conhecimento e políticas de formação docente. Rio de Janeiro: DP\&A, 2003.

SILVA JR, Celestino A; RANGEL, Mary. (Org.). Nove olhares sobre a Supervisão. 9. ed. Campinas-SP: Papirus Editora, 2003.

SILVA, Aída Maria M. (Org.). Retrato da Escola no Brasil. Brasília, DF: CNTE, 2004.

SILVA, Carmem S. B. da. Curso de Pedagogia no Brasil: uma questão em aberto. IN: PIMENTA, Selma G. Pedagogia e Pedagogos - caminhos e perspectivas. São Paulo: Cortez Editora, 2002.

. Curso de pedagogia no Brasil, história e identidade. 3. ed.

Campinas-SP: Autores Associados, 2006.

SILVA, Tomaz Tadeu. (Org.). O Sujeito da Educação. 5. ed. Petrópolis-RJ: Vozes, 1994.

STENHOUSE, L. La investigación como base de la enseñanza. 6. ed. Madri: Morata, 1987.

TARDIF, Maurice. Saberes docentes e formação profissional. 2. ed.

Petrópolis-RJ: Editora Vozes, 2002.

TARDIF, Maurice; LESSARD, Claude. (Org.). 0 ofício de professor: histórias, perspectivas e desafios. Petrópolis: Vozes, 2008.

TEDESCO, Juan Carlos. O novo pacto educativo. São Paulo: Editora Ática, 1995. 
THURLER, Monica Gather. Inovar no interior da Escola. Porto Alegre: ARTMED, 2001.

TORRES, Rosa Maria. Itinerários pela educação latino-americana. Porto Alegre: ARTMED, 2001. Tendências da formação docente nos anos 90 . In: Novas políticas educacionais: críticas e perspectivas. II Seminário Internacional. PUC SP, 1996. Mimeografado.

UNESCO. O perfil dos professores brasileiros: o que fazem, o que pensam, o que almejam. São Paulo: Moderna, 2004.

. Professores e ensino nem mundo em mudança. Relatório Mundial de Educação. Lisboa: ASA, 1998.

VARGAS, Marilda Bonini. Políticas de Formação Inicial de Profissionais da Educação Básica: a experiência dos cursos de Pedagogia da UCBD e UFMS - 1995-2004. Dissertação de Mestrado. Universidade Católica Dom Bosco Campo Grande-MS: 2007.

VASCONCELLOS, Celso dos S. Coordenação do trabalho pedagógico - do projeto político-pedagógico ao cotidiano da sala de aula. 4. ed. São Paulo: Libertad, 2002.

VEIGA, IIma Passos A. (Org.). Caminhos da Profissionalização do Magistério. 3. ed. Campinas-SP: Papirus Editora, 1998.

; AMARAL, Ana Lúcia (Org.); SCHEIBE, Leda; SANTOS, Lucíola Licínio de Castro Paixão Santos; DAMIS, Olga Teixeira; VIEIRA, Sofia Lerche. Formação de Professores - política e debates. 2. ed. Campinas-SP: Papirus, 2002.

; CUNHA, Maria Isabel da. (Org.). Desmistificando a

Profissionalização do Magistério. Campinas-SP: Papirus, 1999.

VIEIRA, Sofia L. Políticas de formação em cenários de reforma. IN: VEIGA, IIma P. A; AMARAL, Ana Lúcia. (Org.). Formação de professores: políticas e debates. Campinas-SP: Papirus, 2002. 
. Educação Básica política e gestão da escola. Brasília- DF: Liber Livro, 2009.

. Educação e gestão: extraindo significados da base legal. In.

SEDUC. Novos paradigmas de gestão escolar. Fortaleza: Edições SEDUC, 2005, p. 07-26.

VIEIRA, Suzane da Rocha. Diretrizes Curriculares para o curso de Pedagogia: pedagogo, docente ou professor? Dissertação de Mestrado. Universidade Federal de Santa Catarina, Florianópolis, 2007.

VIÑAO FRAGO, Antonio. El éxito o fracaso de las reformas educativas: condicionantes, limitaciones, posibilidades. In. SACRISTÁN, J. Gimeno. (Comp.). La reforma necessária: entre la política educativa y la práctica escolar. Madrid: Ediciones Morata, 2006.

WOODS, Peter. Investigar a Arte de Ensinar. Porto-PT: Porto Editora, 1996.

ZEICHNER, K. M. A pesquisa na formação e no trabalho docente. Belo Horizonte, MG: Autêntica, 2002. 


\section{APÊNDICES}

APÊNDICE A - QUESTIONÁRIO APLICADO AOS PROFESSORES-COORDENADORES

APÊNDICE B - QUESTIONÁRIO APLICADO AOS DIRETORES DE ESCOLA

APÊNDICE C - QUESTIONÁRIO APLICADO AOS SUPERVISORES DE ENSINO

APÊNDICE D - QUADRO DOS ASPECTOS DE ANÁLISE DAS MATRIZES CURRICULARES 


\section{FACULDADE DE EDUCAÇÃ̃o DA USP \\ FE USP}

APÊNDICE A - QUESTIONÁRIO APLICADO AOS PROFESSORES-COORDENADORES

\section{INSTRUMENTO DE PESQUISA INTEGRANTE DE DOUTORAMENTO}

Instrumento: Questionário referente à pesquisa desenvolvida para tese de doutoramento junto à Faculdade de Educação da Universidade de São Paulo.

Tema: A formação dos profissionais de Gestão Escolar nos cursos de Pedagogia, pós Diretrizes Curriculares Nacionais do Curso

Objetivo: Analisar os elementos constituintes da profissionalização dos pedagogos que atuam ou atuarão em atividades de administração, coordenação, supervisão e orientação educacional, nos termos do artigo 64 da lei 9394/96. Tais elementos constituintes serão analisados no âmbito dos cursos de Pedagogia e as demandas de sua profissionalidade, a partir da perspectiva do desenvolvimento profissional e institucional nas escolas, tendo como amostragem os profissionais que integram a Rede Pública Estadual de São Paulo.

Tipo de pesquisa: Pesquisa qualitativa que se baseia na análise comparativa de dados a partir da metodologia de triangulação de instrumentos subsidiários (legislação, matrizes dos cursos de Pedagogia e questionário aplicado aos profissionais do magistério).

Pesquisa qualitativa que se baseia na análise comparativa das orientações presentes na legislação, das matrizes dos cursos de Pedagogia e das informações colhidas por meio de questionário aplicado aos profissionais do magistério.

Autor: Alexandre de Paula Franco (Doutorando em Educação pela Faculdade de Educação da Universidade de São Paulo) - aledepafra@hotmail.com

Orientadora: Profa. Dra. Maria Isabel de Almeida mialmei@usp.br

Período de desenvolvimento da pesquisa: março de 2008 a março de 2012 (aplicação do instrumento de pesquisa em 2010).

\footnotetext{
Identificação:

Ofício: Professor Coordenador Pedagógico

Licenciado em Pedagogia: $\operatorname{Sim}($ ); Não ( ).
} 


\section{FACULDADE DE EDUCAÇÃ̃o DA USP \\ FE USP}

Tempo no magistério: 5 a 10 anos ( ); 10 a 15 anos ( ); 15 a 20 anos ( ); mais de 20 anos.

Tempo em atividades de gestão: até 5 anos ( ); 5 a 10 anos ( ); 10 a 15 anos ( ); mais de $15 \operatorname{anos}($ ).

Etapa de atendimento da(s) escola (s) em que atua: Ciclo I ( ); Ciclo II ( ); Ensino Médio ( ).

\section{Questões da Pesquisa:}

1 - Abaixo estão relacionadas as "atribuições/habilidades" que são definidas como fundamentais para o trabalho do Professor-Coordenador-Pedagógico, na Rede Estadual Paulista de Educação, segundo a Resolução SE 88/07. A partir da reflexão sobre os modos como você realiza o seu trabalho de coordenador, indique o grau com que essas atribuições têm sido colocadas em prática por você numa escala de 1 (para a menor presença ou menor domínio) a 5 (para maior presença ou maior domínio):

\begin{tabular}{|l|l|l|l|l|}
\hline $\begin{array}{l}\text { Atribuições/habilidades estabelecidas pela Resolução SE } \\
\mathbf{8 8} / \mathbf{0 7}\end{array}$ & $\mathbf{1}$ & $\mathbf{3}$ & $\mathbf{4}$ & $\mathbf{5}$ \\
\hline $\begin{array}{l}\text { I - acompanhar e avaliar o ensino e o processo de aprendizagem, bem como os } \\
\text { resultados do desempenho dos alunos; }\end{array}$ & & & \\
\hline $\begin{array}{l}\text { II - atuar no sentido de tornar as ações de coordenação pedagógica num espaço } \\
\text { coletivo de construção permanente da prática docente; }\end{array}$ & & & \\
\hline $\begin{array}{l}\text { III - assumir o trabalho de formação continuada, a partir do diagnóstico de } \\
\text { saberes dos professores, para garantir situações de estudo e de reflexão sobre a } \\
\text { prática pedagógica, estimulando os professores a investirem em seu } \\
\text { desenvolvimento profissional; }\end{array}$ & & & & \\
\hline $\begin{array}{l}\text { IV - assegurar a participação ativa de todos os professores do segmento/nível } \\
\text { objeto da coordenação, garantindo a realização de um trabalho produtivo e } \\
\text { integrador; }\end{array}$ & & & & \\
\hline $\begin{array}{l}\text { V - organizar e selecionar materiais adequados às diferentes situações de ensino } \\
\text { e de aprendizagem; }\end{array}$ & & & & \\
\hline $\begin{array}{l}\text { VI - conhecer os recentes referenciais teóricos relativos aos processos de ensino } \\
\text { e aprendizagem para orientar os professores; }\end{array}$ & & & \\
\hline
\end{tabular}




\section{FACULIDADE DE EDUCAÇÃ̃o DA USP \\ FE USP}

VII - divulgar práticas inovadoras, incentivando o uso dos recursos tecnológicos disponíveis.

2 - A partir de sua prática, quais outros conhecimentos/capacidades (até 3) você considera que são intensamente exigidas nas atividades que desenvolve em seu trabalho como professor-coordenador-pedagógico?

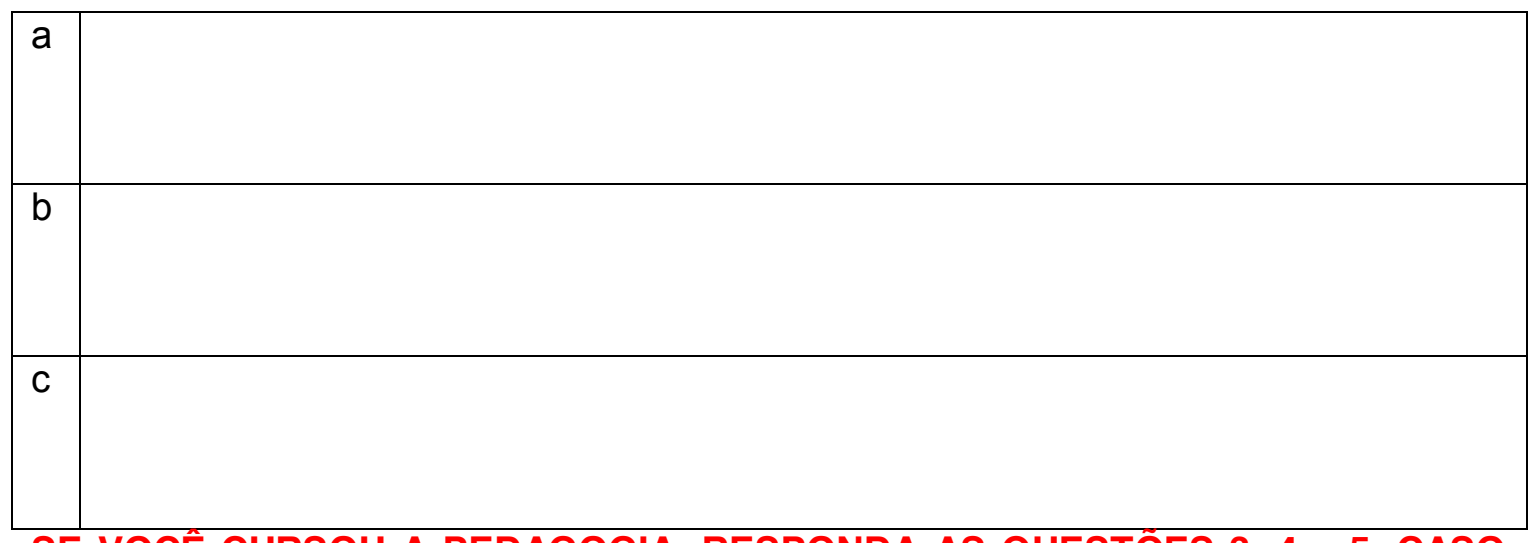

SE VOCÉ CURSOU A PEDAGOGIA, RESPONDA AS QUESTÕES 3, 4 e 5, CASO NÃO, VÁ PARA A QUESTÃO 6.

3 - Quais conhecimentos e saberes (até 3) estiveram presentes durante a realização do seu curso de Pedagogia e, posteriormente, foram (e têm sido) significativos para a realizaçãodo seu trabalho:

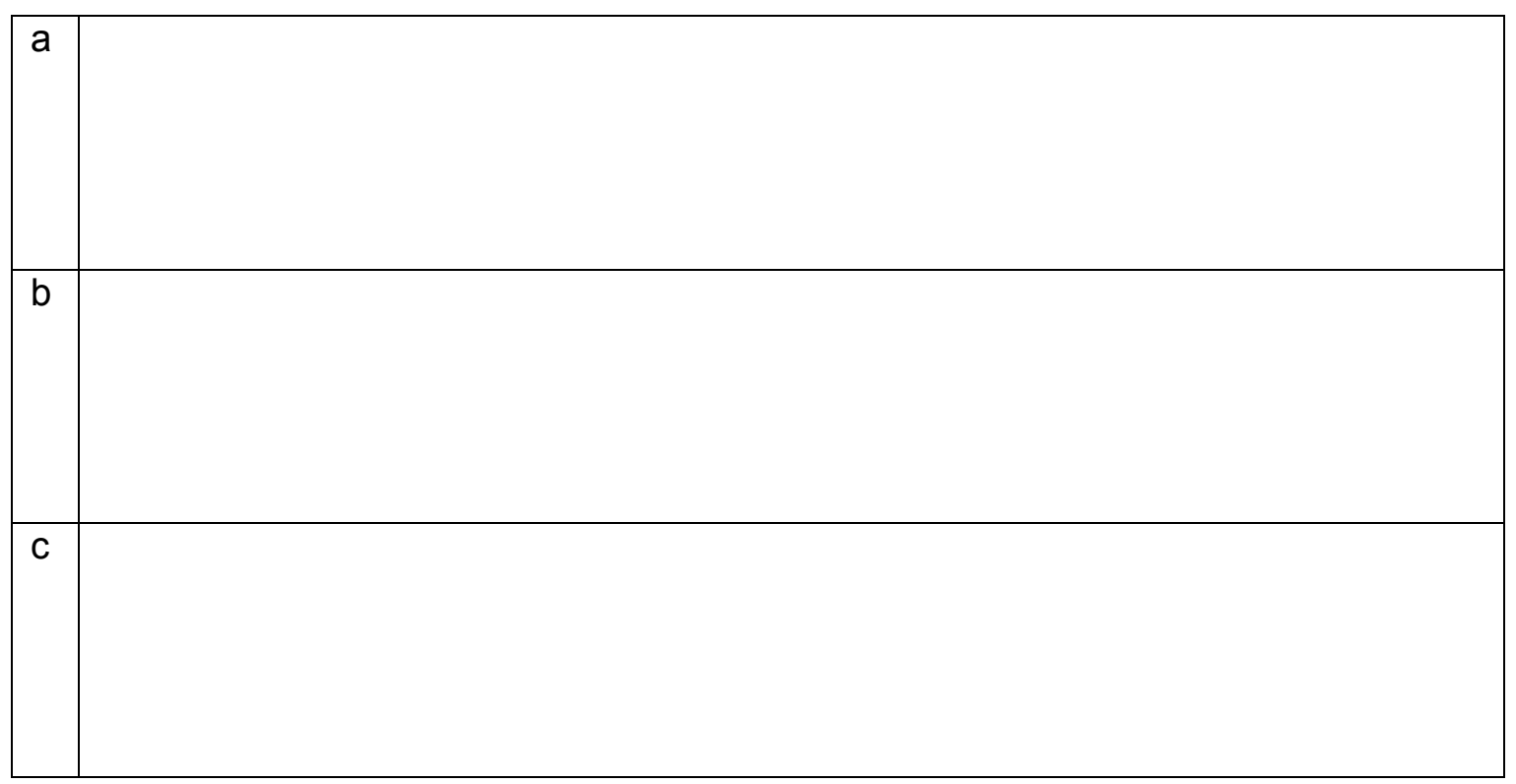




\section{FACULDADE DE EDUCAÇÃ̃o DA USP \\ FE USP}

4 - A partir de sua experiência em coordenação pedagógica, quais aspectos relacionados a conteúdos ou atividades (até 3), você destacaria como relevantes no curso de Pedagogia, que tem a missão de formar os futuros gestores da escola?

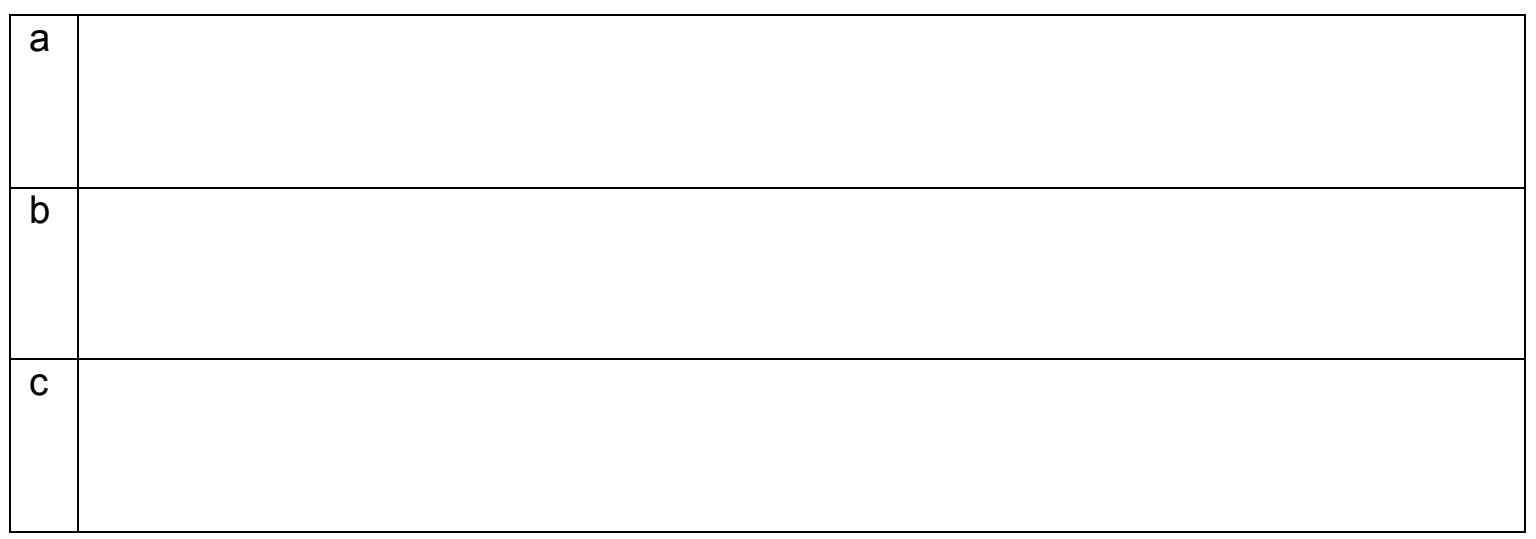

5 - Em relação às exigências de sua atividade como professor-coordenadorpedagógico, aponte aspectos (até 3), que você considera que durante sua formação como pedagogo foram abordados de maneira mais aprofundada ou mais frágil:

\begin{tabular}{|l|l|}
\hline Aspectos mais aprofundados: & Aspectos mais fragilizados: \\
\hline a & a \\
\hline b & b \\
\hline C & \\
\hline
\end{tabular}

\section{QUESTÕES PARA RESPONDER CASO NÃO TENHA CURSADO A PEDAGOGIA}

6 - A partir do trabalho que você desenvolve como professor coordenador pedagógico, você acredita que sua prática poderia ser melhorada com o curso de Pedagogia? Em quais aspectos? 


\section{FACULDADE DE EDUCAÇÃ̃o DA USP \\ FE USP}

7 - Como você não cursou Pedagogia, quais recursos e estratégias utiliza para a seleção de conteúdos e organização de seu trabalho, que é uma atividade essencialmente pedagógica?

\section{QUESTÕES PARA TODOS OS PARTICIPANTES DA PESQUISA}

8 - As atuais Diretrizes Curriculares para o Curso de Pedagogia, estabelecem que os profissionais do magistério responsáveis por atividades de planejamento, coordenação, administração, supervisão, e orientação educacional serão formados neste curso, conforme artigo 64 da LDB. Com base na sua formação profissional e as atividades de trabalho que você desenvolve, você considera que a coordenação pedagógica

( a ) é uma atividade que exige profunda especialização, em razão do conjunto de atividades específicas na escola e, portanto, necessita de uma formação pedagógica geral, e uma forma de habilitação específica no próprio curso de Pedagogia;

( $b$ ) é fundamentalmente articulada aos demais ofícios que o pedagogo desenvolve na organização do trabalho da escola, em atividades de trabalho e, portanto, deve ser formado na Pedagogia, curso que deve garantir a formação dos pedagogos que atuarão em diferentes atividades;

( c ) é atividade desenvolvida articuladamente às demais ofícios que se dedicam à organização dos processos de gestão da escola, entretanto, por se tratar de coordenação pedagógica, deveria ser desenvolvida em curso de Pedagogia específico para as atividades de gestão escolar.

\section{Justificativa:}




\section{FACULDADE DE EDUCAÇÃ̃ DA USP \\ FE USP}

APÊNDICE B - QUESTIONÁRIO APLICADO AOS DIRETORES DE ESCOLA

INSTRUMENTO DE PESQUISA INTEGRANTE DE DOUTORAMENTO

Instrumento: Questionário referente à pesquisa desenvolvida para tese de doutoramento junto à Faculdade de Educação da Universidade de São Paulo.

Tema: A formação dos profissionais de Gestão Escolar nos cursos de Pedagogia, pós Diretrizes Curriculares Nacionais do Curso

Objetivo: Analisar os elementos constituintes da profissionalização dos pedagogos que atuam ou atuarão em atividades de administração, coordenação, supervisão e orientação educacional, nos termos do artigo 64 da lei 9394/96. Tais elementos constituintes serão analisados no âmbito dos cursos de Pedagogia e as demandas de sua profissionalidade, a partir da perspectiva do desenvolvimento profissional e institucional nas escolas, tendo como amostragem os profissionais que integram a Rede Pública Estadual de São Paulo.

Tipo de pesquisa: Pesquisa qualitativa que se baseia na análise comparativa de dados a partir da metodologia de triangulação de instrumentos subsidiários (legislação, matrizes dos cursos de Pedagogia e questionário aplicado aos profissionais do magistério).

Pesquisa qualitativa que se baseia na análise comparativa das orientações presentes na legislação, das matrizes dos cursos de Pedagogia e das informações colhidas por meio de questionário aplicado aos profissionais do magistério.

Autor: Alexandre de Paula Franco (Doutorando em Educação pela Faculdade de Educação da Universidade de São Paulo) - aledepafra@hotmail.com

Orientadora: Profa. Dra. Maria Isabel de Almeida mialmei@usp.br

Período de desenvolvimento da pesquisa: março de 2008 a março de 2012 (aplicação do instrumento de pesquisa em 2010).

\section{Identificação:}

Ofício: Diretor de Escola 


\section{FACULDADE DE EDUCAÇÃ̃ DA USP \\ FE USP}

Licenciado em Pedagogia: Sim ( ); Não ( ).

Tempo no magistério: 5 a 10 anos ( ); 10 a 15 anos ( ); 15 a 20 anos ( ); mais de 20 anos.

Tempo em atividades de gestão: até 5 anos ( ); 5 a 10 anos ( ); 10 a 15 anos ( ); mais de 15 anos ( ).

Etapa de atendimento da(s) escola (s) em que atua: Ciclo I ( ); Ciclo II ( ); Ensino Médio ( ).

\section{Questões da Pesquisa:}

1 - Abaixo estão relacionadas as "competências gerais" que são definidas como fundamentais para um Diretor de Escola, na Rede Estadual Paulista de Educação, segundo a Resolução SE 70/10. A partir da reflexão sobre os modos como você realiza o seu trabalho de Diretor de Escola, indique o grau com que essas atribuições têm sido colocadas em prática por você numa escala de 1 (para a menor presença ou menor domínio) a 5 (para maior presença ou maior domínio):

\begin{tabular}{|c|c|c|c|c|c|}
\hline $\begin{array}{l}\text { Atribuições/habilidades estabelecidas pela Resolução SE } \\
70 / 10\end{array}$ & 1 & 2 & 3 & 4 & 5 \\
\hline $\begin{array}{l}\text { I - Compreender como o contexto social, político e econômico influencia a definição e a } \\
\text { implementação das políticas educacionais. }\end{array}$ & & & & & \\
\hline $\begin{array}{l}\text { II - Dominar e utilizar metodologias de planejamento e tecnologias da informação como } \\
\text { ferramentas para exercer as suas funções. }\end{array}$ & & & & & \\
\hline III - Compreender o papel do Diretor na organização da SEE-SP. & & & & & \\
\hline IV - Analisar e identificar os principais componentes da Proposta Pedagógica da Escola. & & & & & \\
\hline $\begin{array}{l}\text { V - Compreender os processos de implementação das políticas educacionais da SEE-SP } \\
\text { e dos projetos a elas vinculados. }\end{array}$ & & & & & \\
\hline VI - Compreender a visão contemporânea de gestão escolar vinculada a resultados. & & & & & \\
\hline VII - Compreender os sistemas e processos de avaliações externas. & & & & & \\
\hline $\begin{array}{l}\text { VIII - Demonstrar conhecimentos sobre princípios e métodos para exercer a direção da } \\
\text { escola como elemento de apoio e difusor de inovações e boas práticas de ensino } \\
\text { aprendizagem. }\end{array}$ & & & & & \\
\hline IX - Promover e definir ações para formação continuada dos agentes educacionais da & & & & & \\
\hline
\end{tabular}




\section{FACULDADE DE EDUCAÇÃ̃o DA USP \\ FE USP}

escola.

X - Compreender a importância da autoavaliação e do gerenciamento do autodesenvolvimento profissional.

2 - A partir de sua prática, quais outros conhecimentos e capacidades (até 3 ) você considera que são intensamente exigidas nas atividades que desenvolve em seu trabalho como Diretor de Escola?

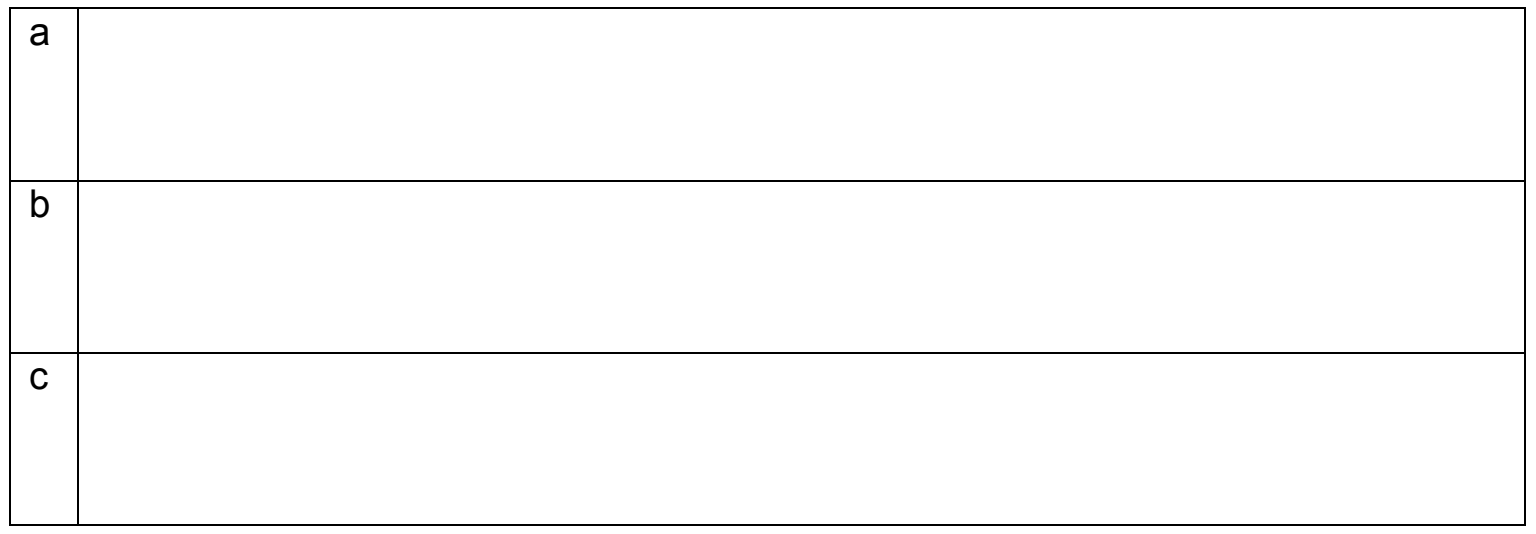

3 - Quais conhecimentos e saberes (até 3 ) estiveram presentes durante a realização do seu curso de Pedagogia, e posteriormente, foram (e têm sido) significativos para a realização do seu trabalho:

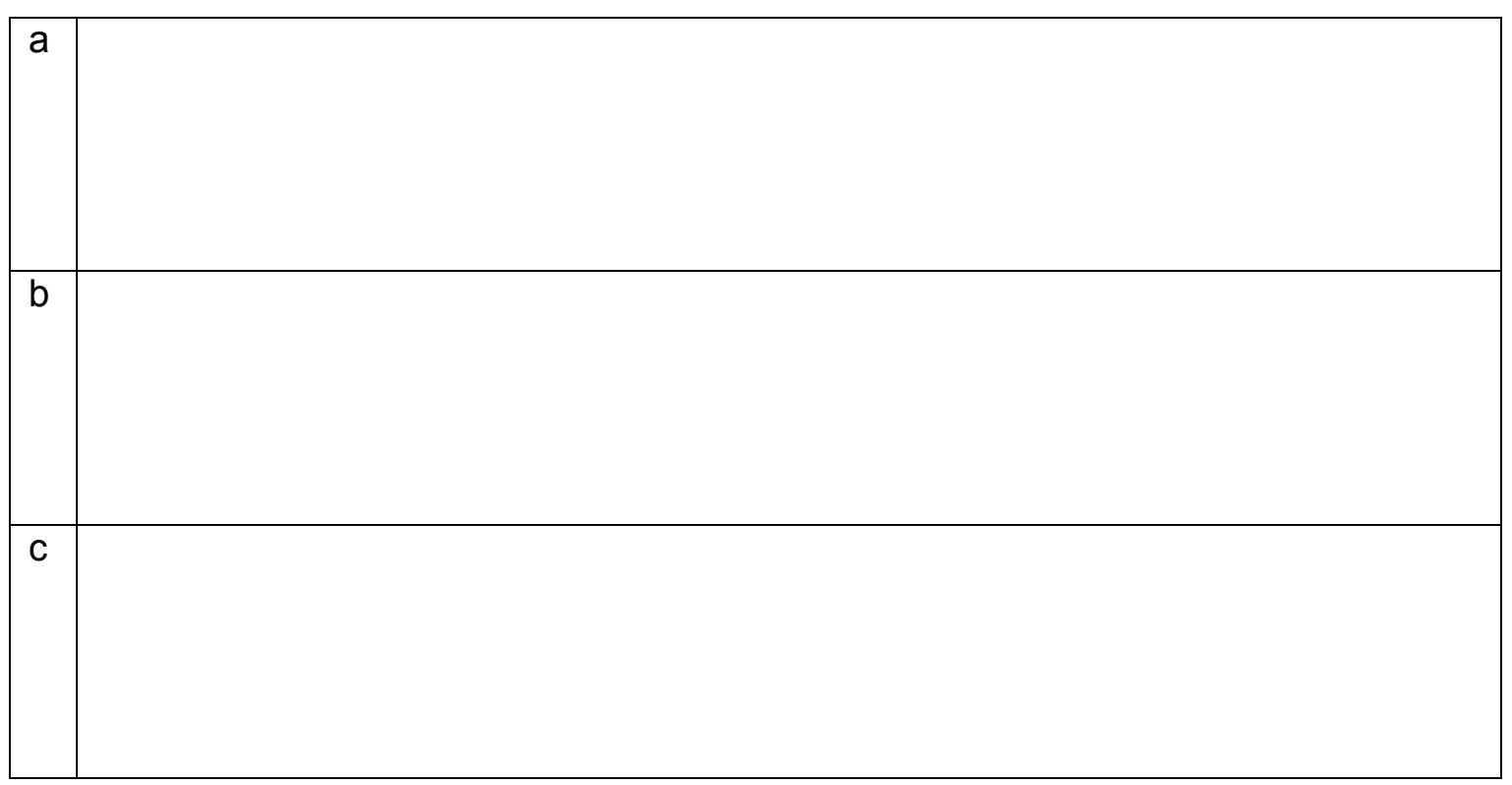

4 - A partir de sua experiência na direção de escola, quais aspectos relacionados a conteúdos ou atividades (até 3), você destacaria como relevantes para estarem 


\section{FACULDADE DE EDUCAÇÃ̃o DA USP \\ FE USP}

presentes no curso de Pedagogia, que tem a missão de formar os futuros gestores da escola?

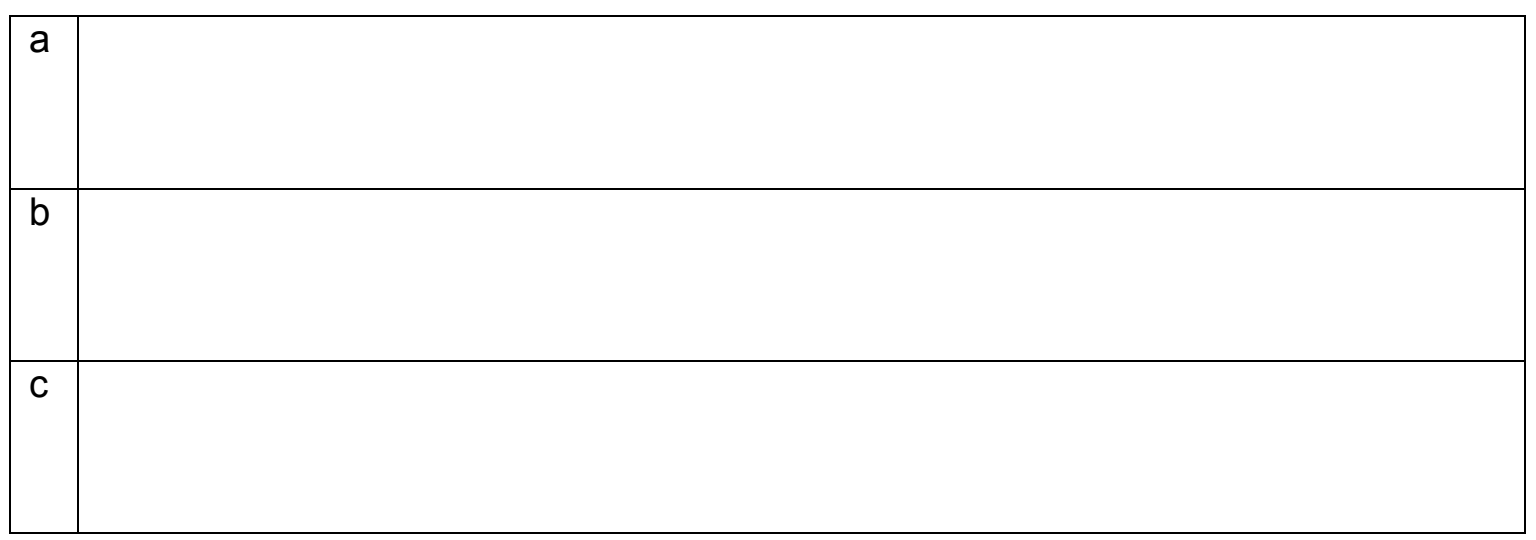

5 - Em relação às exigências de sua atividade como Diretor de Escola, aponte aspectos (até 3), que você considera que durante sua formação como pedagogo foram abordados de maneira mais aprofundada e mais frágil:

\begin{tabular}{|l|l|}
\hline Aspectos mais aprofundados: & Aspectos mais fragilizados: \\
\hline a & a \\
\hline b & b \\
\hline C & \\
\hline
\end{tabular}

8 - As atuais Diretrizes Curriculares para o Curso de Pedagogia, estabelecem que os profissionais do magistério responsáveis por atividades de planejamento, coordenação, administração, supervisão, e orientação educacional serão formados neste curso, conforme artigo 64 da LDB. Com base na sua formação profissional e as atividades de trabalho que você desenvolve, você considera que a direção de escola

( a ) é uma atividade que exige profunda especialização, em razão do conjunto de atividades específicas na escola e, portanto, necessita de uma formação pedagógica geral, e uma formação específica no próprio curso de Pedagogia.

( b ) é fundamentalmente articulada aos demais ofícios que o pedagogo desenvolve na organização do trabalho da escola, em atividades de trabalho e, portanto, deve ser formado na 


\section{FACULDADE DE EDUCAÇÃ̃ DA USP FE USP}

Pedagogia, curso que deve garantir a formação dos pedagogos que atuarão em diferentes atividades.

( c ) é atividade desenvolvida articuladamente aos demais ofícios que se dedicam à organização dos processos de gestão da escola, entretanto, por se tratar de direção/administração, deveria ser desenvolvida em curso de Pedagogia específico para as atividades de gestão escolar.

\section{Justificativa:}




\section{FACULDADE DE EDUCAÇÃ̃ DA USP \\ FE USP}

APÊNDICE C - QUESTIONÁRIO APLICADO AOS SUPERVISORES DE ENSINO

INSTRUMENTO DE PESQUISA INTEGRANTE DE DOUTORAMENTO

Instrumento: Questionário referente à pesquisa desenvolvida para tese de doutoramento junto à Faculdade de Educação da Universidade de São Paulo.

Tema: A formação dos profissionais de Gestão Escolar nos cursos de Pedagogia, pós Diretrizes Curriculares Nacionais do Curso

Objetivo: Analisar os elementos constituintes da profissionalização dos pedagogos que atuam ou atuarão em atividades de administração, coordenação, supervisão e orientação educacional, nos termos do artigo 64 da lei 9394/96. Tais elementos constituintes serão analisados no âmbito dos cursos de Pedagogia e as demandas de sua profissionalidade, a partir da perspectiva do desenvolvimento profissional e institucional nas escolas, tendo como amostragem os profissionais que integram a Rede Pública Estadual de São Paulo.

Tipo de pesquisa: Pesquisa qualitativa que se baseia na análise comparativa de dados a partir da metodologia de triangulação de instrumentos subsidiários (legislação, matrizes dos cursos de Pedagogia e questionário aplicado aos profissionais do magistério).

Pesquisa qualitativa que se baseia na análise comparativa das orientações presentes na legislação, das matrizes dos cursos de Pedagogia e das informações colhidas por meio de questionário aplicado aos profissionais do magistério.

Autor: Alexandre de Paula Franco (Doutorando em Educação pela Faculdade de Educação da Universidade de São Paulo) - aledepafra@hotmail.com

Orientadora: Profa. Dra. Maria Isabel de Almeida mialmei@usp.br

Período de desenvolvimento da pesquisa: março de 2008 a março de 2012 (aplicação do instrumento de pesquisa em 2010).

\section{Identificação:}

Ofício: Supervisor de Ensino 


\section{FACULDADE DE EDUCAÇÃ̃ DA USP \\ FE USP}

Licenciado em Pedagogia: Sim ( ); Não ( ).

Tempo no magistério: 5 a 10 anos ( ); 10 a 15 anos ( ); 15 a 20 anos ( ); mais de 20 anos.

Tempo em atividades de gestão: até 5 anos ( ); 5 a 10 anos ( ); 10 a 15 anos ( ); mais de 15 anos ( ).

Etapa de atendimento da(s) escola (s) em que atua: Ciclo I ( ); Ciclo II ( ); Ensino Médio ( ).

\section{Questões da Pesquisa:}

1 - Abaixo estão relacionadas as "competências gerais" que são definidas como fundamentais para um Diretor de Escola, na Rede Estadual Paulista de Educação, segundo a Resolução SE 70/10. A partir da reflexão sobre os modos como você realiza o seu trabalho de Supervisor de Ensino, indique o grau com que essas atribuições têm sido colocadas em prática por você numa escala de 1 (para a menor presença) a 5 (para maior presença):

\begin{tabular}{|l|l|l|l|l|}
\hline $\begin{array}{l}\text { Atribuições/habilidades estabelecidas pela Resolução SE } \\
\text { 70/10 }\end{array}$ & $\mathbf{2}$ & $\mathbf{3}$ & $\mathbf{4}$ & $\mathbf{5}$ \\
\hline $\begin{array}{l}\text { I - Compreender como o contexto social, político e econômico influencia a definição e a } \\
\text { implementação das políticas educacionais. }\end{array}$ & & & \\
\hline $\begin{array}{l}\text { II - Dominar e utilizar metodologias de supervisão e tecnologias da informação como } \\
\text { ferramentas para exercer as suas funções. }\end{array}$ & & & \\
\hline III - Compreender o papel da Diretoria de Ensino na organização da SEE-SP. & & & & \\
\hline $\begin{array}{l}\text { IV - Analisar e identificar os principais componentes de um Plano de Educação em nível } \\
\text { nacional, estadual e regional. }\end{array}$ & & & \\
\hline $\begin{array}{l}\text { V - Compreender os processos de implementação das políticas educacionais da SEE-SP } \\
\text { e dos projetos a elas vinculados. }\end{array}$ & & & & \\
\hline VI - Compreender a visão contemporânea de gestão escolar vinculada a resultados. & & & & \\
\hline VII - Compreender os sistemas e processos de avaliações externas. & & & & \\
\hline $\begin{array}{l}\text { VIII - Demonstrar conhecimentos, princípios e métodos para exercer a supervisão como } \\
\text { elemento catalisador e difusor de inovações e boas práticas de ensino-aprendizagem. }\end{array}$ & & & & \\
\hline IX - Diagnosticar as necessidades de formação continuada dos agentes educacionais. & & & & \\
\hline
\end{tabular}




\section{FACULIDADE DE EDUCAÇÃ̃o DA USP \\ FE USP}

$X$ - Compreender a importância da autoavaliação e do gerenciamento do autodesenvolvimento profissional.

2 - A partir de sua prática, quais outros conhecimentos e capacidades (até 3) você considera que são intensamente exigidas nas atividades que desenvolve em seu trabalho como Supervisor de Ensino?

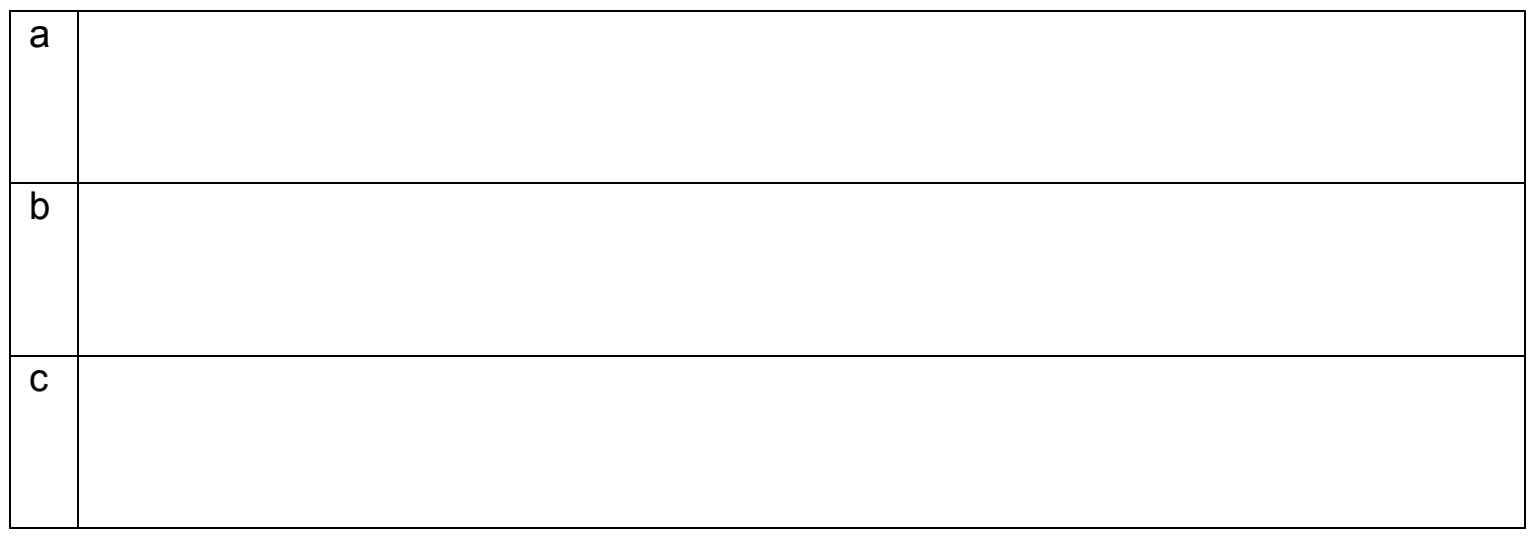

3 - Quais conhecimentos e saberes (até 3) estiveram presentes durante a realização do seu curso de Pedagogia, e posteriormente, foram (e têm sido) significativos para a realização do seu trabalho:

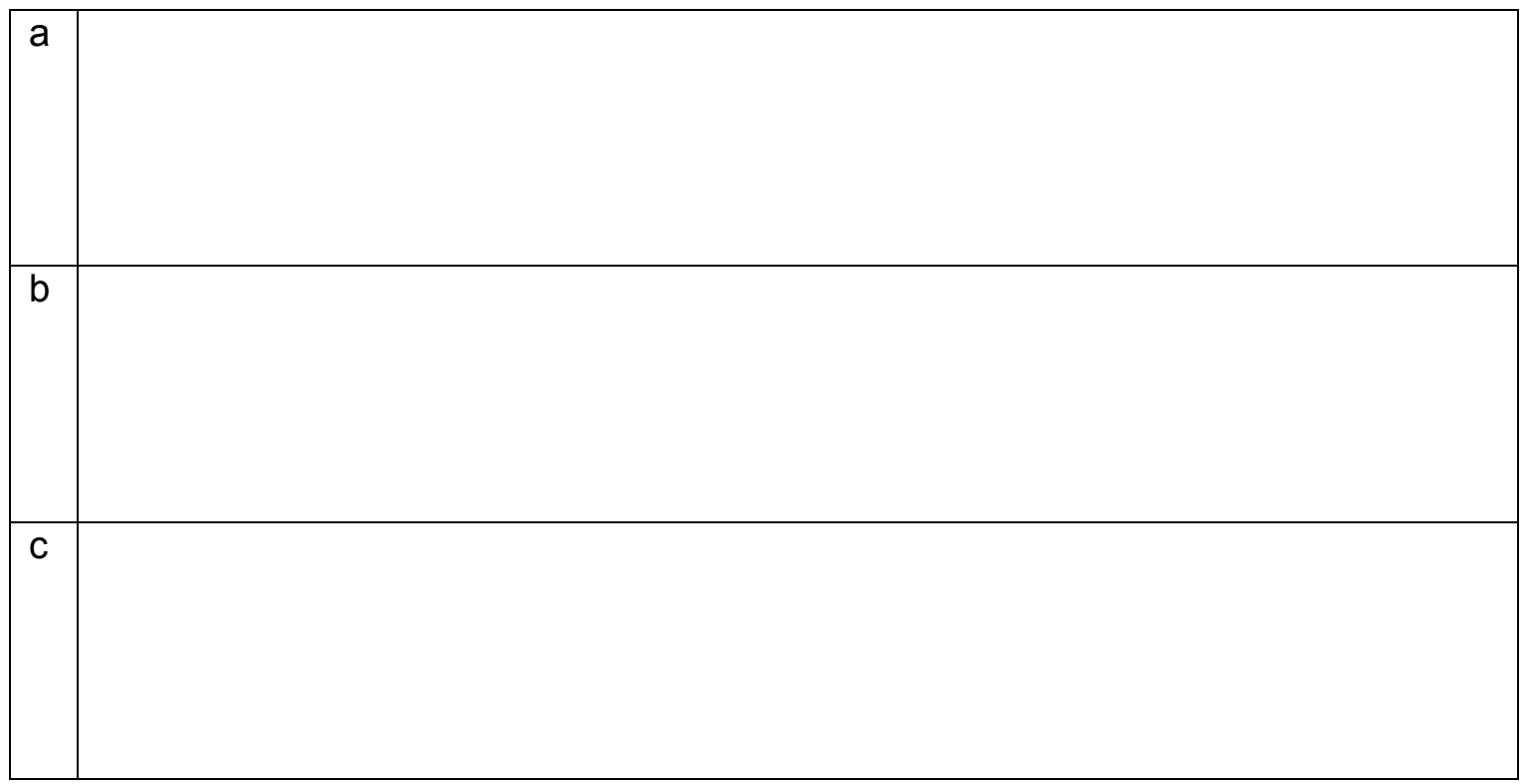

4 - A partir de sua experiência na supervisão de ensino, quais aspectos relacionados a conteúdos ou atividades (até 3), você destacaria como relevantes no curso de Pedagogia, que tem a missão de formar os futuros gestores da escola ? 


\section{FACULDADE DE EDUCAÇÃ̃o DA USP \\ FE USP}

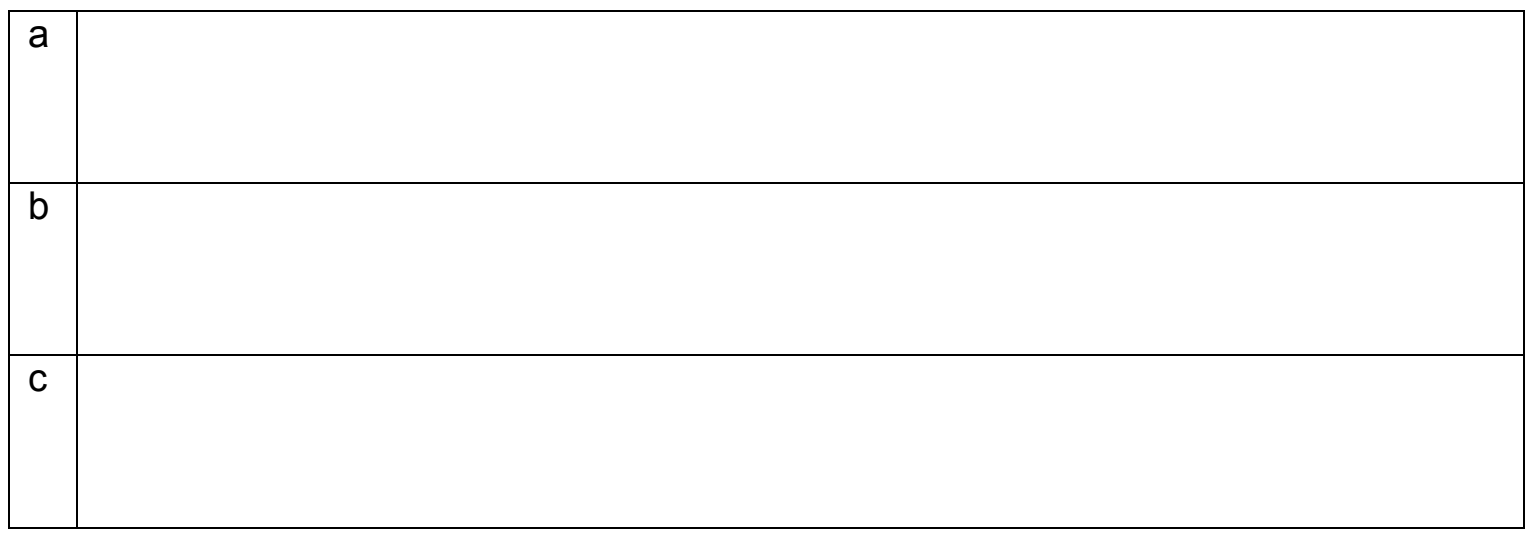

5 - Em relação às exigências de sua atividade como Supervisor de Ensino, aponte aspectos (até 3), que você considera que durante sua formação como pedagogo foram abordados de maneira mais aprofundada ou mais frágil:

\begin{tabular}{|l|l|}
\hline Aspectos mais aprofundados: & Aspectos mais fragilizados: \\
\hline a & a \\
\hline b & b \\
\hline C & \\
\hline
\end{tabular}

8 - As atuais Diretrizes Curriculares para o Curso de Pedagogia, estabelecem que os profissionais do magistério responsáveis por atividades de planejamento, coordenação, administração, supervisão, e orientação educacional serão formados neste curso, conforme artigo 64 da LDB. Com base na sua formação profissional e nas atividades de trabalho que você desenvolve, você considera que a supervisão de ensino

( a ) é uma atividade que exige profunda especialização, em razão do conjunto de atividades específicas na escola e, portanto, necessita de uma formação pedagógica geral, e uma formação específica no próprio curso de Pedagogia;

( b ) é fundamentalmente articulada aos demais ofícios que o pedagogo desenvolve na organização do trabalho da escola, em atividades de trabalho e, portanto, deve ser formado na Pedagogia, curso que deve garantir a formação dos pedagogos que atuarão em diferentes atividades; 


\section{FACULDADE DE EDUCAÇÃ̄o DA USP FE USP}

( c ) é atividade desenvolvida articuladamente às demais ofícios que se dedicam à organização dos processos de gestão da escola, entretanto, por se tratar de direção/administração, deveria ser desenvolvida em curso de Pedagogia específico para as atividades de gestão escolar.

Justificativa:

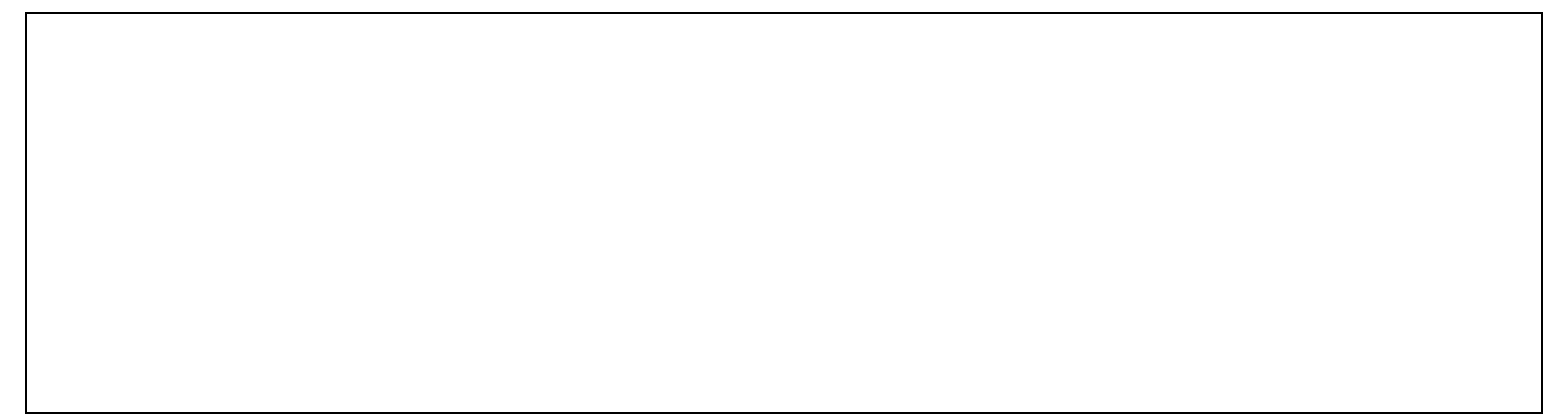




\section{FACULDADE DE EDUCAÇÃO DA USP \\ FE USP}

APÊNDICE D - QUADRO DOS ASPECTOS DE ANÁLISE DAS MATRIZES CURRICULARES

\section{ASPECTOS DE ANÁLISE DOS CURSOS DE PEDAGOGIA NA PESQUISA}

(SOB O ASPECTO DA FORMAÇÃO PARA A GESTÃO ESCOLAR nOS 130 CURSOS)

\begin{tabular}{|c|c|c|c|c|c|c|c|c|c|c|c|}
\hline \multirow{2}{*}{$\begin{array}{c}\text { Identificação } \\
\text { da } \\
\text { Instituição } \\
\text { (1) }\end{array}$} & \multirow{2}{*}{$\begin{array}{c}\text { Região } \\
\text { (2) }\end{array}$} & \multicolumn{2}{|l|}{$\begin{array}{c}\text { Tipo } \\
\text { (3) }\end{array}$} & \multicolumn{2}{|c|}{$\begin{array}{l}\text { Organização } \\
\text { do curso (4) }\end{array}$} & \multirow{2}{*}{$\begin{array}{c}\text { Disciplinas do } \\
\text { campo } \\
\text { de Gestão } \\
\text { (5) }\end{array}$} & \multirow{2}{*}{$\begin{array}{l}\text { C Horária } \\
\text { Disciplina } \\
\text { (6) }\end{array}$} & \multirow{2}{*}{$\begin{array}{c}\text { Semestre } \\
\text { oferecim } \\
\text { (7) }\end{array}$} & \multicolumn{2}{|c|}{ Estágio (8) } & \multirow{2}{*}{$\begin{array}{c}\text { Disciplinas } \\
\text { Diversas } \\
\text { (9) }\end{array}$} \\
\hline & & Urbana & Rural & Sem & Anual & & & & Sim & Não & \\
\hline
\end{tabular}

1 - Identificação da instituição que oferece o curso analisado (não publicado na versão final da pesquisa).

2 - Região geográfica do país na qual o curso é oferecido.

3 - Característica regional da área de localização do curso.

4 - Forma modular de organização do curso para sua integralização, com a respectiva duração do mesmo.

5 - Disciplinas oferecidas no curso que são diretamente ligadas a formação do pedagogo para atuação nos ofícios de gestão escolar.

6 - Carga horária das referidas disciplinas de gestão escolar.

7 - Semestre no qual a (s) disciplina (s) de gestão é (são) oferecida (s) no curso de Pedagogia.

8 - Existência da proposta de estágio supervisionado do curso vinculado às práticas de gestão escolar.

9 - Existência de disciplinas diversas aos campos de atuação da docência, e que se configuram como especificidades do curso. 